PRISCILA HESS LOPES

ESTUDO DOS MECANISMOS MOLECULARES ENVOLVIDOS NA AÇÃO TÓXICA DAS ESFINGOMIELINASES D DO VENENO DE ARANHAS Loxosceles E DE SUA MODULAÇÃO PELO USO DE INIBIDORES

Tese apresentada ao Programa de PósGraduação em Imunologia do Instituto de Ciências Biomédicas da Universidade de São Paulo, para obtenção do Título de Doutor em Ciências. 
PRISCILA HESS LOPES

\section{ESTUDO DOS MECANISMOS MOLECULARES ENVOLVIDOS NA AÇÃO TÓXICA DAS ESFINGOMIELINASES D DO VENENO DE ARANHAS Loxosceles E DE SUA MODULAÇÃO PELO USO DE INIBIDORES}

Tese apresentada ao Programa de PósGraduação em Imunologia do Instituto de Ciências Biomédicas da Universidade de São Paulo, para obtenção do Título de Doutor em Ciências.

Área de concentração: Imunologia

Orientadora: Dra. Denise Vilarinho Tambourgi

Versão original 
DADOS DE CATALOGAÇÃO NA PUBLICAÇÃO (CIP)

Serviço de Biblioteca e Informação Biomédica do

Instituto de Ciências Biomédicas da Universidade de São Paulo

reprodução não autorizada pelo autor

Lopes, Priscila Hess.

Estudo dos mecanismos moleculares envolvidos na ação tóxica das Esfingomielinases $\mathrm{D}$ do veneno de aranhas Loxosceles e de sua modulação pelo uso de inibidores / Priscila Hess Lopes. -- São Paulo, 2013.

Orientador: Profa. Dra. Denise Vilarinho Tambourgi.

Tese (Doutorado) - Universidade de São Paulo. Instituto de Ciências Biomédicas. Departamento de Imunologia. Área de concentração: Imunologia. Linha de pesquisa: Imunobiologia de venenos de animais peçonhentos / Mecanismos moleculares envolvidos na patogênese do envenenamento por espécies de aranhas Loxosceles.

Versão do título para o inglês: Study of the molecular mechanisms involved in the toxic action of sphingomyelinases $\mathrm{D}$ from Loxosceles spider venom and its modulation by the use of inhibitors.

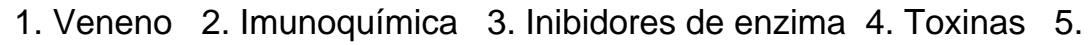
Aranhas 6. Animais peçonhentos I. Tambourgi, Profa. Dra. Denise Vilarinho II. Universidade de São Paulo. Instituto de Ciências Biomédicas. Programa de Pós-Graduação em Imunologia III. Título. 
Candidato(a):

Título da Tese:
Priscila Hess Lopes.

Estudo dos mecanismos moleculares envolvidos na ação tóxica das Esfingomielinases $D$ do veneno de aranhas Loxosceles e de sua modulação pelo uso de inibidores.

Orientador(a):

Profa. Dra. Denise Vilarinho Tambourgi.

A Comissão Julgadora dos trabalhos de Defesa da Tese de Doutorado, em sessão pública realizada a .......... considerou
( ) Aprovado(a)
( ) Reprovado(a)

\begin{tabular}{|c|c|}
\hline Examinador(a): & $\begin{array}{l}\text { Assinatura: } \\
\text { Nome: ......... } \\
\text { Instituição: . }\end{array}$ \\
\hline Examinador(a): & $\begin{array}{l}\text { Assinatura: } \\
\text { Nome: ......... } \\
\text { Instituição: . }\end{array}$ \\
\hline Examinador(a): & $\begin{array}{l}\text { Assinatura: } \\
\text { Nome: ......... } \\
\text { Instituição: . }\end{array}$ \\
\hline Examinador(a): & $\begin{array}{l}\text { Assinatura: } \\
\text { Nome: ........ } \\
\text { Instituição: }\end{array}$ \\
\hline Presidente: & $\begin{array}{l}\text { Assinatura: } \\
\text { Nome: ......... } \\
\text { Instituição: . }\end{array}$ \\
\hline
\end{tabular}




\section{CERTIFICADO}

Certificamos que o Projeto intitulado "Estudo dos mecanismos moleculares envolvidos na ação tóxica de Smases D de Loxosceles e de sua modulação pelo uso de inibidores" protocolo $n^{\circ}$ 805/11, sob a responsabilidade de Denise V. Tambourgi e Priscila Hess Lopes, está de acordo com os Princípios Éticos na Experimentação Animal adotado pelo Colégio Brasileiro de Experimentação Animal (COBEA), e foi aprovado pela COMISSÃO DE ÉTICA NO USO DE ANIMAIS DO INSTITUTO BUTANTAN (CEUAIB) em reunião de 10/03/2011

\begin{tabular}{|c|l|}
\hline $\begin{array}{c}\text { Vigência do Projeto: } \\
04 / 2011-06 / 2012\end{array}$ & \multicolumn{1}{c|}{$\mathbf{N}^{\circ}$ de animais/espécie } \\
\hline Laboratório de Imunoquímica & $\begin{array}{l}372 \text { camundongos Balb/c Machos } \\
126 \text { coelhos Machos }\end{array}$ \\
\cline { 2 - 2 }
\end{tabular}

São Paulo, 17 de março de 2011.

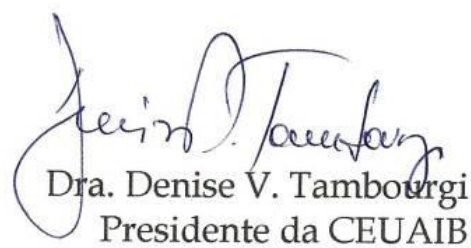


UNIVERSIDADE DE SÃO PAULO INSTITUTO DE CIÊNCIAS BIOMÉDICAS

Cidade Universitária "Armando de Salles Oliveira"

Av. Prof. Lineu Prestes, 2415 - CEP. 05508-000 São Paulo, SP Brasil

Telefone :(55) (011) 3091.7733 - e-mail: cep@icb.usp.br

Certificado

Certificamos que o protocolo registrado sob n ${ }^{\circ} \mathbf{1 2 6}$ nas fls. $\mathbf{1 3 4}$ do livro $\mathbf{0 2}$ para uso de animais em Aula, sob a responsabilidade do Prof(a) Dr(a)) Denise Vilarinho Tambourgi, Coordenador (a) da Linha de pesquisa "Estudo dos mecanismos moleculares envolvidos na ação tóxica de esfingomielinases $D$ de Loxosceles e de sua modulação pelo uso de inibidores" do qual participam o(s) aluno(s), Priscila Hess Lopes, está de acordo com os Princípios Éticos de Experimentação Animal adotado pela Sociedade Brasileira de Ciência de Animais de Laboratório (SBCAL) e foi aprovado pela COMISSÃO DE ÉTICA NO USO DE ANIMAIS (CEUA) em 07.12.2012, com validade de 4 anos.

São Paulo, 11 de dezembro de 2012.

Uhxima.

Prof. Dr. WOTHAN TAVARES DE LIMA Coordenador-CEUA - ICB/USP

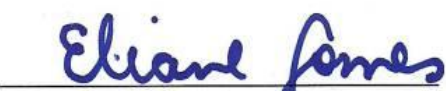

Profa. Dra. ANA PAL (A LEPIQUE Secretária- CEUA - ICB/USP 
Cidade Universitária "Armando de Salles Oliveira"

Av. Prof. Lineu Prestes, 2415 - cep. 05508-000 São Paulo, SP - Brasi

Telefone :(55) (11) 3091.7733 telefax : (55) (11) 3091-8405

e-mail: cep@ icb.usp.br

São Paulo, 28 de novembro de 2012.

\section{PARECER 1088/CEP}

A Comissão de Ética em Pesquisas em Seres Humanos do ICB, na sessão realizada no dia 22.11.2012, APROVOU o projeto intitulado: "Estudo dos mecanismos moleculares envolvidos na ação tóxica de Esfingomielinases $D$ de Loxosceles e de sua modulação pelo uso de inibidores", dos autores DeNISE V.TAMBOURGI e Priscila Hess Lopes.

Cabe aos Pesquisadores executantes elaborar e apresentar a este Comitê, relatórios anuais (parciais ou final ), de acordo com a resolução 196/06 do Conselho Nacional da Saúde, item IX. 2 letra c.

O primeiro relatório deverá ser encaminhado à Secretaria deste CEP em 22.11.2013.

Atenciosamente,

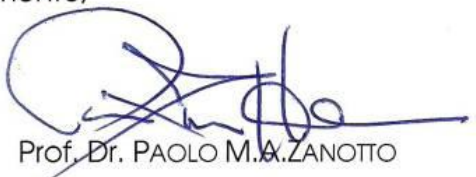

Prof. Dr. PAOLO M.LA.ZANOTIO

Coordenador da Comissão de Ética em

Pesquisas com Seres Humanos - ICB/USP 


\begin{abstract}
À Denise Tambourgi
Por abrir as portas do laboratório e me receber no momento em que mais precisei;

Por me ensinar o quanto apaixonar-se pelo que se faz é importante;

Por me permitir conquistar sua confiança no meu trabalho e;

Por ser sempre um grande exemplo.

Obrigada!
\end{abstract}

\begin{abstract}
À Maria de Fátima Furtado e Marisa Rocha
Por estarem ao meu lado e não me abandonarem um só momento, sejam eles bons ou ruins; Por serem mais que orientadora ou colega de trabalho, por serem a força e o apoio, por serem amigas, por serem mães.

Obrigada!

\author{
À Selene Elífio-Esposito, Júlio Cesar Moura-Leite e Luiz Fernando Pereira \\ Por me ensinarem os primeiros passos; \\ Por acreditarem no meu futuro; \\ Por sempre me incentivarem no caminho que escolhi seguir. \\ Obrigada!
}

"Se hoje realizo um grande sonho, é por que um dia lá no início, vocês sonharam comigo." 


\begin{abstract}
À Dulce Eliza Hess e Luiz Henrique Hess Lopes. Por acreditarem e sempre me apoiarem em minhas decisões, por estarem sempre comigo sendo o meu abrir de olhos a cada novo amanhecer. "Vocês são minha força e persistência, meus olhos e coração, vocês são o que há de melhor em mim”. Amo vocês!
\end{abstract}

À Flávia R. Amend. Por sempre acreditar em mim, me apoiar em absolutamente tudo e mesmo longe estar comigo em todos os instantes dos meus dias. Por me ensinar o verdadeiro sentido da palavra amizade e me mostrar que nenhum caminho é longo e tortuoso demais quando um amigo nos acompanha. Te amo!

“A amizade é a existência de uma só alma em dois corpos”. Aristóteles.

À Paulo Henrique Alves da Silva. Por acreditar em minha capacidade e no meu futuro, por se orgulhar e incentivar minha carreira, por me apoiar nas mais difíceis decisões e por trazer à minha vida motivos para acreditar no amor e voltar a sorrir. Te amo! "Amor é apenas uma palavra, até que você encontre alguém que dê um verdadeiro sentido a ela”. 


\section{AGRADECIMENTOS}

Agradeço a Deus, pela força, pelo dom da persistência e por sempre iluminar meus caminhos.

A Dra. Denise Tambourgi, pela oportunidade de aprender ao seu lado, por compartilhar um pouco de sua experiência comigo, por todos os ensinamentos, valiosos conselhos e pela confiança. Muito obrigada!

A meus pais Dulce E. Hess e Luiz A. S. Lopes, pelo incentivo e orgulho de sempre, por acreditarem em mim, por entenderem minhas ausências e por estarem ao meu lado a cada passo dado no longo caminho da vida. A vocês devo tudo!

A meu irmão Luiz Henrique Hess Lopes, por sempre me incentivar, se orgulhar e por nunca deixar que eu me sentisse sozinha. Você é e sempre será o meu menino, meu melhor amigo e pra sempre vou cuidar de você. Te amo!

Ao Paulo Henrique Alves da Silva, meu amor, meu companheiro, meu menino, meu herói, por acreditar no meu trabalho e me apoiar em todas as decisões, por trazer de volta a força que achei que não existia mais em mim e por me mostrar realmente o que é ser feliz. "Pra ter o seu amor, eu viajei pelo seu mundo, me vi com seus olhos, descobri quem sou; Pra ter o seu amor, te pedi pra Deus de presente, pra me ver contente, Ele te inventou" (J\&M). Te amo!

A Sueli, Fernanda, Douglas, Tainara e Nelson, por acreditarem no meu trabalho e futuro, por me receberem na família com tanto amor e carinho. Amo vocês, obrigada!

A amiga, irmã, fonte de força e inspiração Flávia Amend, pelo apoio e incentivo incondicionais, por mesmo distante ser presença constante nos meus dias, por sempre se orgulhar de mim e principalmente por essa amizade sincera que cultivamos a cada dia. $\mathrm{O}$ brilho nos olhinhos da pequena Joana Amend também é uma força para continuar. Amo vocês eternamente!

A amiga, segunda mãe, grande incentivadora Josianne Amend, pelo apoio incondicional, pelo carinho, pela torcida, por se orgulhar de mim como uma mãe se orgulha de um filho. Te amo. Obrigada!

Ao meu padrinho, meu segundo pai, Cláudio Hess, por todo o incentivo, por ser sempre presente e por estar orgulhoso desta conquista. Ela é sua também!

Aos meus familiares: Vovó Antonia, pelo incentivo, por se orgulhar de sua neta e por ser o pilar que sustenta a união desta família. Esta conquista também é sua e do Vovô Hugo (in memoriam)! As tias Neli, Roseli, Solange e Rosana, aos tios Didi, Magno e Celso e aos primos Rodrigo, Fábio, Fernanda, Mauro, Luccas, Dudu e Ana Cláudia. O apoio e incentivo de vocês foram fundamentais. Obrigada, amo todos vocês!

A Dra. Rute M. Gonçalves de Andrade pela coleta e dedicada manutenção do biotério de aranhas, pelas extrações de veneno e por sempre me ensinar tanto em nossas longas conversas durante as extrações.

Ao Dr. Mário Murakami, pela colaboração nos estudos de Docking molecular.

Ao Dr. Jorge M. Ferreira Jr., pelo auxílio na citometria de fluxo, pelas cervejas, pelos cafés e pelas ótimas risadas. 
A Dra. Fernanda Portaro, por sempre acreditar na minha capacidade, por contribuir para este trabalho compondo a banca do exame de qualificação e defesa, pelo auxílio com os experimentos de cinética enzimática, por nossas longas e ótimas conversas e pela amizade.

Ao Pesquisador Fábio Magnoli, por ser sempre atencioso, por me fazer companhia nos dias em que ficava até tarde no laboratório e pela amizade.

Ao Dr. Osvaldo Sant'anna e Dr. Wilmar Dias da Silva, a presença de vocês nos ensina muito a cada dia, é um prazer imensurável poder completar minha formação profissional ao lado de grandes pessoas e profissionais como vocês.

A Lia Aguiar, por ser sempre atenciosa, por toda a ajuda e pelos momentos de descontração no laboratório.

A Elaine Rodrigues, por também sempre estar pronta a nos ajudar, pelas caronas, vários cafés, lanches e pela sempre ótima companhia, regada a boas risadas mostrando sempre que independente de qualquer coisa há o lado bom da vida.

A Carolina Liaw, pelo auxílio com os assuntos burocráticos, por nossas agradáveis conversas. Obrigada!

Ao Sr. Severino Ramos, pelo auxílio com os animais no biotério do Laboratório de Imunoquímica.

Aos demais funcionários do Laboratório de Imunoquímica: Ana Freire, Ana Cláudia, Guilherme, Alécio, Ricardo, Maura, Silvia e Marcinha. A ajuda e o carinho de vocês foram fundamentais. Em especial agradeço a Marcinha, pelo carinho, pelos conselhos, por compartilhar comigo um pouco de sua experiência de vida.

A Dra. Cinthya K. Okamoto (Cintinha) pelo grande auxílio técnico na fase inicial do desenvolvimento do projeto. Aprendi muito com você, jamais esquecerei todo o apoio. Muito obrigada!

A Dra. Giselle Pidde Queiroz, por estar sempre disposta a ajudar, pelo auxílio em assuntos de biologia molecular, pela companhia nas noites até tarde no laboratório e pelas boas risadas.

Aos amigos do laboratório de imunoquímica: Angela (Ascaris), Mariana (Marys), Estevam (Moguerço), Gi, Cinthya, Daniel, Felipe França (Najam), Karina, Felipe Guidolin, Emerson, Dani Myamoto (Danizinha), Gabi, Dani Paixão, Marie, Joel, Osmair, Dani Cajado, Alexandre e os recém-chegados Aurélio e Lygia, pela companhia, por compartilharem experiências profissionais e pessoais, angústias, medos e boas notícias, por nos apoiarmos mutuamente diante das adversidades, pelas bobeiras, pelas risadas (muitas risadas) e pelo prazer de conviver e dividir os dias com vocês. Vocês foram fundamentais, a cada dia fazendo com que grandes problemas não passassem apenas de pequenas frustrações. Obrigada!

A Miriam Silva e Alessandra Veloso, pela ajuda na adaptação no laboratório, pelas boas risadas e pela amizade.

A Carla C. Squaiella (Carlotinha), Isadora M. Villas-Boas (Izildinha) e Luciana Carvalho (Luluzinha), por além de colegas de trabalho ajudando e compartilhando suas experiências profissionais, tornarem-se grandes AMIGAS. Agradeço pelos conselhos, pelo apoio nas horas difíceis e por se alegrarem com minhas conquistas. Levarei vocês sempre no meu coração. Obrigada! 
A Dra. Maria de Fátima Furtado, pela amizade e apoio em todas as horas, por estar presente nos momentos difíceis e por se alegrar com minhas conquistas.

A Dra. Marisa Rocha, por muito me ensinar, por me mostrar o quanto a persistência é importante na área em que escolhemos trabalhar, por também estar presente nos momentos difíceis e por se alegrar com minhas conquistas.

Ao Dr. Francisco França, por sempre acreditar no meu trabalho, acreditar que tudo daria certo, pelo apoio, incentivo e pela amizade.

Aos professores e amigos Selene Elífio-Esposito, Luiz Fernando Pereira e Júlio Cesar de Moura-Leite, por me ensinarem os primeiros passos e me incentivarem a continuar, por serem exemplos para que eu pudesse me espelhar e seguir em frente. Obrigada!

Aos amigos do Laboratório de Herpetologia: Wilson Fernandes, Sávio Santana, Kathleen Grego e Daniel Stuginski. É muito bom saber que posso contar com vocês, obrigada pelo apoio e torcida!

Aos companheiros de república: Lilian Parpinelli, Leonardo Oliveira, Vivian Parpinelli e Maria Vianna, pelo apoio e pela amizade! Teria sido muito mais difícil sem vocês! Obrigada!

A amiga Grande Paula Lassen, por acreditar no meu trabalho, pelo apoio e pela amizade! Obrigada amiga, seu apoio é fundamental, amo você!

Aos amigos Thaís Narcizo e Rodrigo Chaves de Oliveira, por sempre me levarem para mais perto de Deus, por me mostrarem o quanto é importante nunca perder a fé, por acreditarem e se orgulharem desta conquista e pela amizade que ficará para sempre comigo. Amo vocês!

A família Dias de Oliveira: Maria do Carmo, Joaquim, Adriano e Renato, pelo apoio nos momentos difíceis e pela amizade. Agradeço também a Gabriela, Bruno, Juliana, tia Rose e tio Gonzaga, pelo apoio e amizade devotados. Obrigada!

Aos secretários da Pós Graduação em Imunologia: Amarildo Utiama (in memoriam) e Eni Sacramento Santos, pela ajuda no processo de mudança de orientador e pelo auxílio nos assuntos burocráticos da pós-graduação.

A Dra. Sandra Farsky e Dr. Alexandre Steiner pela composição da banca do meu exame de qualificação.

A FAPESP, CAPES, CNPq e INCTTox pelo apoio financeiro.

\author{
"Ali onde eu chorei, \\ Qualquer um chorava, \\ Dar a volta por cima que eu dei, \\ Quero ver quem dava. \\ Reconhece a queda e não desanima, \\ Levanta, sacode a poeira e dá a volta por cima". \\ Paulo. E. Vanzolini.
}


"E assim, depois de muito esperar, num dia como outro qualquer, decidi triunfar.

Decidi não esperar as oportunidades e sim, eu mesmo buscá-las.

Decidi ver cada problema como uma oportunidade de encontrar uma solução.

Decidi ver cada deserto como uma possibilidade de encontrar um oásis.

Decidi ver cada noite como um mistério a resolver.

Decidi ver cada dia como uma nova oportunidade de ser feliz.

Naquele dia, descobri que meu único rival não era mais que minhas próprias

limitações e que enfrentá-las era a única e melhor forma de superá-las. Naquele dia, descobri que eu não era o melhor e que talvez eu nunca tivesse sido.

Deixei de me importar com quem ganha ou perde.

Agora me importa simplesmente saber melhor o que fazer. Aprendi que o difícil não é chegar lá em cima, e sim deixar de subir.

Aprendi que o melhor triunfo é poder chamar alguém de amigo. Descobri que o amor é mais que um simples estado de enamoramento, "o amor é uma filosofia de vida".

Naquele dia, deixei de ser um reflexo dos meus escassos triunfos passados e passei a ser uma tênue luz no presente. Aprendi que de nada serve ser luz se não iluminar o caminho dos demais. Naquele dia, decidi trocar tantas coisas. Naquele dia, aprendi que os sonhos existem para tornar-se realidade. E desde aquele dia já não durmo para descansar... simplesmente durmo para sonhar".

Walt Disney. 


\section{RESUMO}

HESS, P. L. Estudo dos mecanismos moleculares envolvidos na ação tóxica das esfingomielinases D do veneno da aranha Loxosceles e de sua modulação pelo uso de inibidores. 2013. 142 f. Tese (Doutorado em Imunologia) - Instituto de Ciências Biomédicas, Universidade de São Paulo, São Paulo, 2013.

O veneno de aranhas do gênero Loxosceles consiste em uma mistura de proteínas com atividade tóxica ou enzimática, incluindo as esfingomielinases D (SMases D), as quais são consideradas como o principal componente tóxico responsável pelo estabelecimento dos efeitos locais e sistêmicos. Com base na estrutura da SMase D I de Loxosceles laeta e em estudos de Docking molecular foram identificados compostos químicos potencialmente capazes de interagir com as esfingomielinases e inibir a sua atividade tóxica. No presente estudo, foi avaliada a ação destas moléculas em modelos de loxoscelismo cutâneo e sistêmico. Além disso, este projeto buscou aprofundar as análises sobre os mecanismos de ação do veneno/toxina para melhor entendimento da patogênese dos envenenamentos por Loxosceles. Análises fluorimétricas mostraram que dos 14 compostos selecionados por docking, os compostos 1, 5, 6, 8 e 10 foram capazes de inibir a atividade hidrolítica das SMases recombinantes e nativas, presentes no veneno, sobre os substratos esfingomielina e lisofosfatidilcolina. Curvas dose-resposta mostraram que o inibidor 5 foi o mais eficiente com $\mathrm{IC}_{50}$ de $45,4 \mu \mathrm{M}$. A análise do mecanismo de inibição, mostrou que os compostos 5 e 6 são inibidores incompetitivos com valores de $K_{i}$ de 1,63 e 1,73, respectivamente, e o composto 1 é um inibidor do tipo misto com $K_{i}$ of $1.70 \mu \mathrm{M}$. Os cinco compostos foram capazes de inibir a ligação das SMases D aos eritrócitos humanos e a indução da remoção da glicoforina $C$ da superfície destas células, importante evento para o desenvolvimento da hemólise dependente do sistema complemento. Na ação sobre queratinócitos humanos, os compostos 5 e 6 foram capazes de reduzir a ligação das SMases à membrana e a morte celular, assim como de reduzir a expressão/secreção de MMP-2 e 9 por estas células. No modelo de loxoscelismo cutâneo utilizando coelhos, os compostos 5 e 6 foram capazes de reduzir em aproximadamente 40$60 \%$ a lesão necrótica, sendo que a análise histopatológica revelou que estes compostos foram capazes de reduzir o infiltrado inflamatório e a desorganização das fibras colágenas. No entanto, no loxoscelismo sistêmico nenhum dos compostos foi eficaz na inibição da atividade letal do veneno. No estudo dos mecanismos moleculares de ação, foi revelado que a toxina foi capaz de induzir a ativação de MAPK ERK1/2 e que todos os cinco compostos causaram redução na ativação desta via de sinalização celular. A apoptose dos queratinócitos, induzida pela SMase, não se dá por ação de receptores de morte como Fas/FasL e TNF-R1. A toxina é capaz de induzir stress oxidativo com a produção do ânion superóxido nestas células, bem como citocinas como IL- $1 \beta$, IL-6, TNF- $\alpha$ e TGF- $\beta 1$. Os resultados indicam que inibidores específicos da SMase D são capazes de controlar as reações cutâneas e sistêmicas induzidas pelos venenos de Loxosceles. Estas moléculas são promissoras ferramentas para estudos de estrutura/função e para o desenvolvimento de novas intervenções terapêuticas para o loxoscelismo.

Palavras-chave: Loxosceles. Veneno. Esfingomielinase D. Inibidores. Dermonecrose. Hemólise. 


\begin{abstract}
HESS, P. L. Study of the molecular mechanisms involved in the toxic action of sphingomyelinases D from Loxosceles spider venom and its modulation by the use of inhibitors. 2013. 142 p. Ph. D. thesis (Immunology) - Instituto de Ciências Biomédicas, Universidade de São Paulo, São Paulo, 2013.
\end{abstract}

The venom of spiders from Loxosceles genus consists in a mixture of proteins with enzymatic or toxic activity, including the sphingomyelinases D (SMases D), which are considered the main toxic component responsible for the establishment of local and systemic effects. Based on the structure of SMase D I from Loxosceles laeta and in molecular Docking studies, it was possible to identify chemical compounds potentially able to interact with sphingomyelinases and inhibit their toxic activity. In the present study, we evaluated the action of these molecules in models of cutaneous and systemic loxoscelism. In addition, this project sought to deepen the analyses on the action mechanisms of the venom/toxin, in order to better understand the genesis of the envenoming process by Loxosceles spider. Fluorometric analysis showed that from the 14 compounds selected by docking, compounds 1, 5, 6, 8 and 10 were able to inhibit the hydrolytic activity of the recombinant and native SMases, present in the venom, over the lysophosphatidylcholine and sphingomyelin substrates. Dose-response curves showed that the inhibitor 5 was more efficient with $\mathrm{IC}_{50}$ of $45.4 \mu \mathrm{M}$. The analysis of the inhibition mechanism showed that compounds 5 and 6 are uncompetitive inhibitors with $K_{i}$ values of 1.63 and 1.73 , respectively, and the compound 1 is an inhibitor of the mixed type with $K_{i}$ value of $1.70 \mu \mathrm{M}$. The five compounds were able to inhibit the binding of SMases D to human erythrocytes and the removal of glycophorin $C$ from these cells surface, important events in the development of complement-dependent hemolysis. Regarding to the action on human keratinocytes, compounds 5 and 6 were able to reduce the binding of SMases to the membrane and the cell death, as well as the expression/secretion of MMP-2 and 9. In the cutaneous model of loxoscelism using rabbits, the compounds 5 and 6 were able to reduce approximately $40-60 \%$ of the necrotic lesion and the histopathological analysis revealed that these compounds were able to reduce the inflammatory infiltrate and the dissociation of the collagen fibers. However, in the systemic loxoscelism, none of the compounds was effective in inhibiting the venom lethal activity. In the study of molecular mechanisms of action, it was revealed that the toxin was able to induce the activation of MAPK ERK1/2 and all five compounds were able to reduce the activation of this cell signaling pathway. The apoptosis in keratinocytes, induced by SMases, does not occur by the action of the death receptors such as Fas/FasL and TNF-R1. The toxin is able to induce oxidative stress with the production of superoxide anion in these cells, as well as cytokines such as IL-1 $\beta$, IL- 6 , TNF- $\alpha$ and TGF- $\beta 1$. The results indicate that specific inhibitors of SMase D are capable to control local and systemic reactions induced by Loxosceles venoms. These molecules are promising tools for structure/function studies and development of new therapeutic interventions for the loxoscelism.

Keywords: Loxosceles. Venom. Sphingomyelinase D. Inhibitors. Dermonecrose. Hemolysis. 


\section{LISTA DE ILUSTRAÇÕES}

Figura 1 - Exemplares de aranhas Loxosceles laeta ................................................................... 23

Figura 2 - Sequencia deduzida de aminoácidos da SMase I de L. laeta .................................. 28

Figura 3 - Predição da estrutura secundária da SMase I de L. laeta ......................................... 29

Figura 4 - Representação esquemática da estrutura terciária da SMase I de L.laeta ................. 31

Figura 5 - Resíduos de aminoácidos da molécula de SMase I indicados como sítio de ligação para os ligantes estudados no docking molecular ................................................................. 40

Figura 6 - Estrutura química dos compostos candidatos a inibidores de SMases D .................. 43

Figura 7 - Análise eletroforética das amostras obtidas durante o processo de purificação da SMase I por cromatografia de afinidade

Figura 8 - Análise eletroforética do veneno de L. laeta e da SMase I recombinante após a

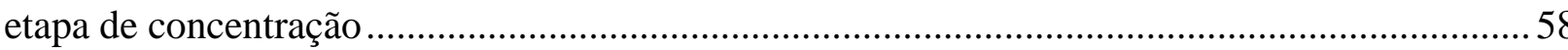

Figura 9 - Hidrólise da esfingomielina e lisofosfatidilcolina ...............................................59

Figura 10 - Viabilidade de células HaCat tratadas com veneno ou toxina recombinante de $L$. laeta

Figura 11 - Hemólise dependente do sistema complemento.

Figura 12 - Análise da interferência dos diluentes dos compostos inibidores na atividade esfingomielinásica

Figura 13 - Ação dos inibidores sobre a hidrólise da esfingomielina (SM) 65

Figura 14 - Curvas dose resposta da inibição da atividade esfingomielinásica 66

Figura 15 - Comparação entre os valores de $\mathrm{IC}_{50}$ dos inibidores 67

Figura 16 - Ação dos inibidores sobre a hidrólise da lisofosfatidilcolina (LPC) 68

Figura 17 - Mecanismo de inibição dos compostos 1, 5 e 6 sobre a atividade hidrolítica da SMase I sobre o substrato esfingomielina

Figura 18 - Análise da ação de inibidores de SMases celulares sobre a atividade hidrolítica da

SMase I de L. laeta

Figura 19 - Análise da capacidade dos compostos em inibir a ligação das SMases D à superfície de eritrócitos e induzir a clivagem da glicoforina C (GPC) 73

Figura 20 - Representação da correlação estatística entre a ligação da toxina à membrana do eritrócito versus clivagem de glicoforina C (GPC)

Figura 21 - Viabilidade de células HaCat tratadas com SMase I ou veneno de L. laeta na presença ou ausência dos inibidores. 
Figura 22 - Análise da capacidade dos compostos em inibir a ligação das SMases D à superfície de queratinócitos humanos

Figura 23 - Representação da correlação estatística entre a ligação da toxina à membrana do queratinócito versus viabilidade celular

Figura 24 - Dosagem de MMP-2 e 9 no sobrenadante de cultura de queratinócitos tratados com veneno de L. laeta na presença ou ausência dos inibidores

Figura 25 - Ação dos inibidores sobre dermonecrose induzida pelo veneno de L. laeta in vivo

Figura 26 - Porcentagem de inibição da lesão dermonecrótica induzida pelo veneno de L. laeta in vivo

Figura 27 - Curva dose reposta do inibidor 5 sobre a lesão dermonecrótica induzida pelo veneno de L. laeta in vivo.....

Figura 28 - Curva dose reposta do inibidor 6 sobre a lesão dermonecrótica induzida pelo veneno de L. laeta in vivo.

Figura 29 - Análise histopatológica de fragmentos de pele de coelhos inoculados com veneno de L. laeta na presença ou ausência do inibidor 1

Figura 30 - Análise histopatológica de fragmentos de pele de coelhos inoculados com veneno de L. laeta na presença dos inibidores 5 e 6

Figura 31 - Análise histopatológica de fragmentos de pele de coelhos inoculados com veneno de L. laeta na presença dos inibidores 8 e 10

Figura 32 - Ação da SMase I e veneno de L. laeta sobre a via de sinalização ERK1/2 em queratinócitos

Figura 33 - Produção de ROS e RNOS por queratinócitos humanos tratados com SMase I

Figura 34 - Ação da SMase I sobre a expressão dos receptores de TNF na superfície de queratinócitos humanos .95

Figura 35 - Dosagem de citocinas no sobrenadante de cultura de queratinócitos humanos tratados com SMase I 


\section{LISTA DE TABELAS}

Tabela 1 - Compostos candidatos a inibidores de SMases D selecionados nos estudos de Docking molecular.

Tabela 2 - Propriedades físico-químicas e valores de Goldscore atribuídos para cada ligante...

Tabela 3 - Doses utilizadas e porcentagem de DMSO presente na solução dos inibidores em cada ensaio 46

Tabela 4 - Concentração Mínima Inibitória 50\% ( $\left.\mathrm{IC}_{50}\right)$ dos compostos sobre a atividade hidrolítica da SMase I 


\section{SUMÁRIO}

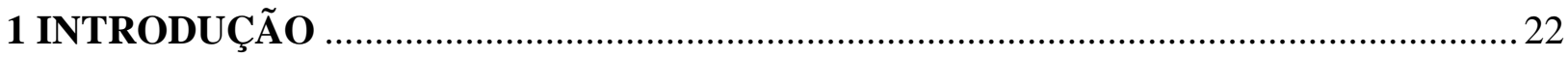

1.1 Aranhas do gênero Loxosceles e o loxoscelismo ......................................................... 22

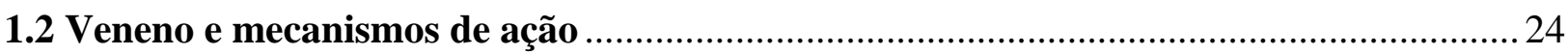

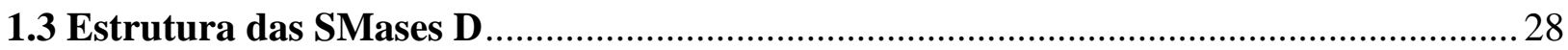

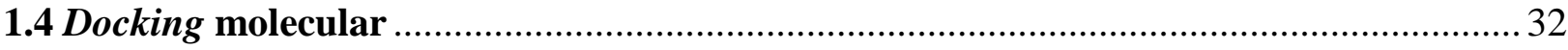

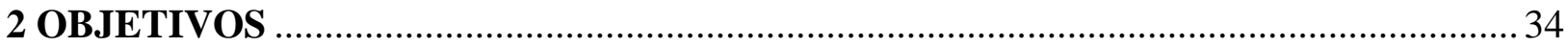

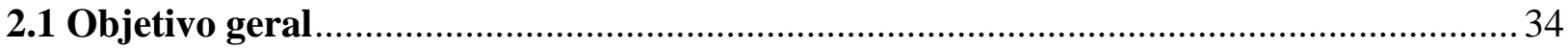

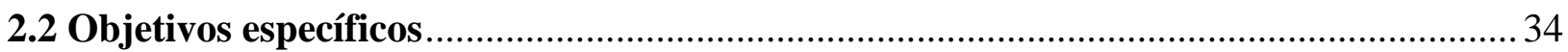

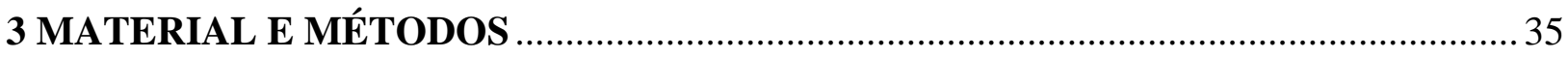

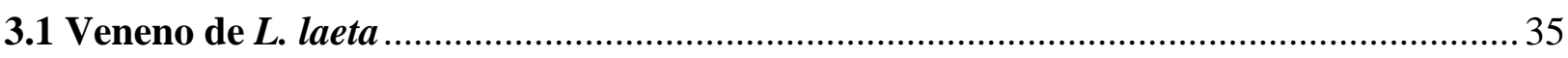

3.2 Expressão e purificação da SMase I de L. laeta ............................................................. 35

3.3 Análise da presença de endotoxina nas amostras de veneno e toxina recombinante

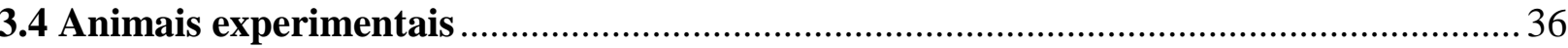

3.5 Análise eletroforética do veneno de $L$. laeta e da toxina recombinante..........................36

3.6 Caracterização das atividades do veneno de $L$. laeta e da toxina

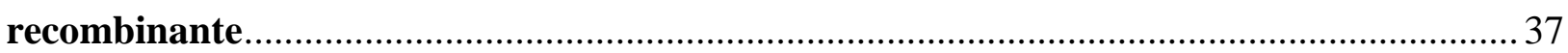

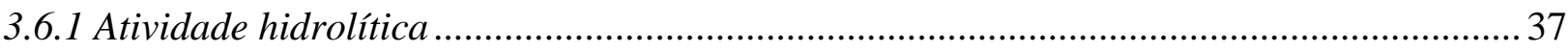

3.6.2 Atividade hemolitica dependente de complemento......................................................... 37

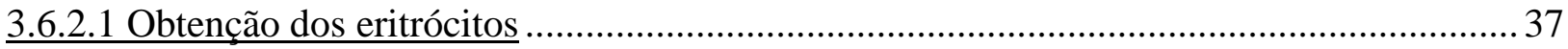

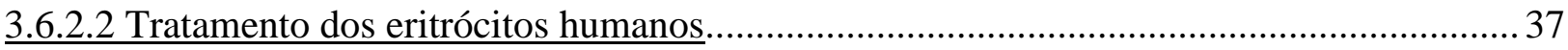

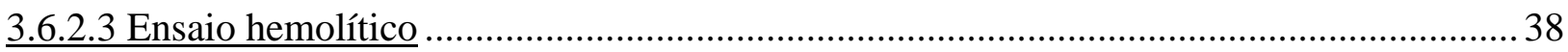

3.7 Ação do veneno de L. laeta e SMase I sobre queratinócitos humanos: viabilidade

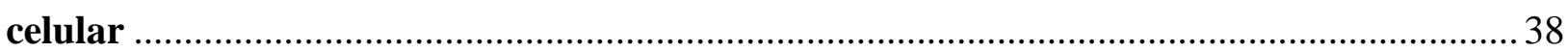

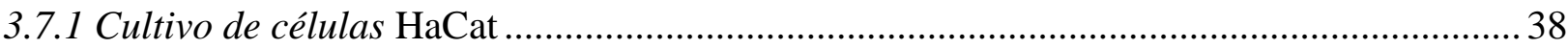

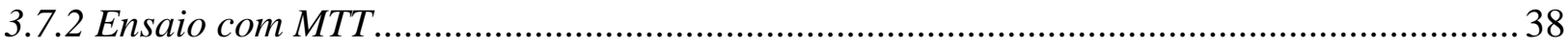

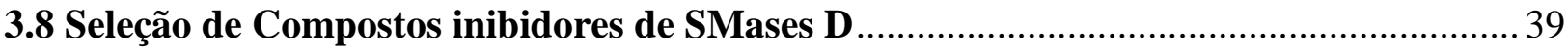

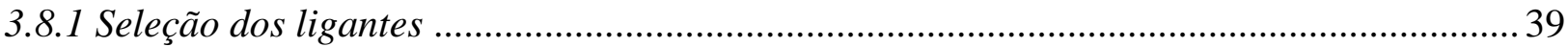

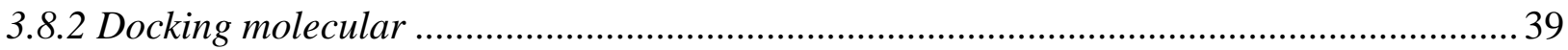

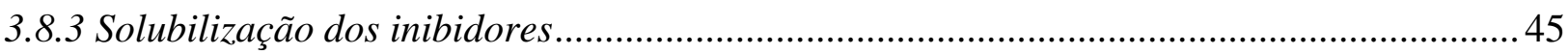

3.8.4 Determinação da fluorescência basal dos inibidores .................................................... 45 
3.9 Doses utilizadas e tratamento das amostras com os inibidores

3.10 Análise da ação dos inibidores sobre a atividade hidrolítica das SMases D .46

3.10.1 Determinação dos valores de $I C_{50}$ 47

3.10.2 Análise do mecanismo de inibição 47

3.11 Análise da ação dos inibidores sobre o loxoscelismo sistêmico 48

3.10.1 Ação dos inibidores sobre o mecanismo de hemólise ..... 48

3.10.2 Letalidade do veneno 48

3.12 Análise da ação dos inibidores sobre o loxoscelismo cutâneo

3.12.1 Ação dos inibidores sobre a atividade das SMases D em queratinócitos humanos in vitro

3.12.1.1 Análise da viabilidade celular: ensaio com MTT

3.12.1.2 Tratamento das células para citometria de fluxo.

3.12.2 Ligação das SMases D à superfície dos queratinócitos

3.12.3 Dosagem de MMPs no sobrenadante de cultura dos queratinócitos 50

3.12.4 Ação dos inibidores sobre a dermonecrose induzida pelo veneno de L. laeta in vivo

3.12.4.1 Análise histopatológica das lesões dermonecróticas.

3.13 Novos estudos sobre o mecanismo de ação das SMases D de Loxosceles

3.13.1 Análise da participação da via de sinalização intracelular pERK 1/2 no mecanismo de ação das SMases D.

3.13.1.1 Tratamento das células e preparo das amostras.

3.13.1.2 Ensaio para detecção de pERK 1/2.

3.13.2 Análise da produção de espécies reativas do oxigênio (ROS) e do nitrogênio (RNOS) por queratinócitos humanos tratados com a SMase I.

3.13.3 Investigação do mecanismo de apoptose induzido pelas SMases D em queratinócitos humanos.

3.13.3.1 Análise da expressão de Fas (CD95) e FasL (CD178).

3.13.3.2 Análise da expressão dos receptores de TNF (CD120a e CD120b)....

3.13.4 Dosagem de citocinas no sobrenadante de cultura de queratinócitos humanos tratados com a SMase I

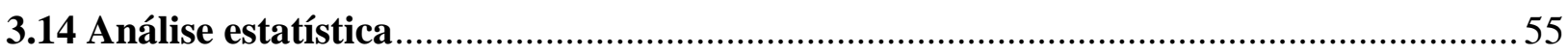

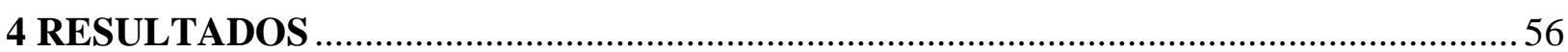

4.1 Análise da presença de endotoxina nas amostras de veneno e toxina recombinante 
4.2 Expressão e purificação da SMase I recombinante

4.3 Perfil eletroforético do veneno e da toxina recombinante ............................................5 58

4.4 Caracterização das atividades do veneno e da toxina recombinante............................59

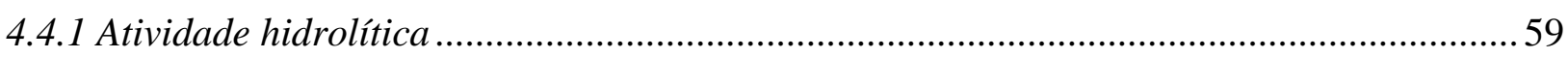

4.4.2 Ação sobre queratinócitos humanos: viabilidade celular ................................................ 60

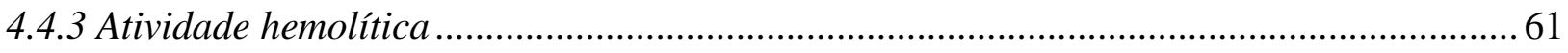

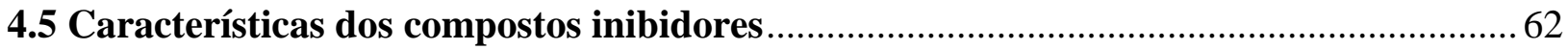

4.6 Análise da ação dos compostos selecionados nos estudos de Docking sobre a atividade hidrolítica .64

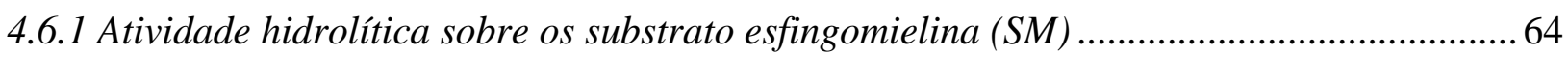

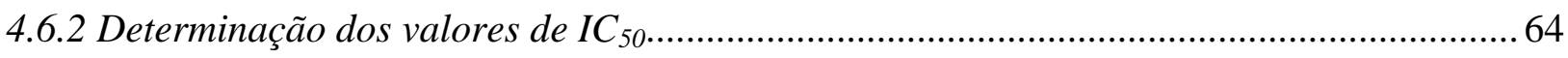

4.6.3 Atividade hidrolitica sobre o substrato lisofosfatidilcolina (LPC) .....................................64

4.6.4 Análise do mecanismo de inibição

4.6.5 Ação de inibidores de esfingomielinases celulares endógenas sobre a atividade da

SMase I de L. laeta.

4.7 Ação dos inibidores sobre o loxoscelismo sistêmico ….............................................. 72

4.6.1 Análise do controle da hemólise pelos compostos: avaliação da clivagem de GPC e ligação das SMases D à superfície de eritrócitos ..................................................................... 72

4.6.2 Análise da ação dos inibidores sobre o potencial letal do veneno ..................................... 74

4.8 Ação dos inibidores sobre o loxoscelismo cutâneo …………………............................... 75

4.8.1 Análise da viabilidade celular de queratinócitos humanos ............................................. 75

4.8.2 Ação dos inibidores sobre a ligação das SMases D á superfície de queratinócitos humanos.....

4.8.3 Ação dos inibidores sobre a produção de MMPs por queratinócitos humanos

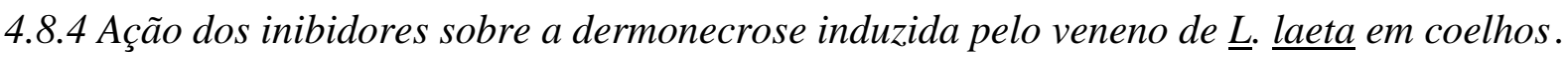

4.8.4.1 Análise histopatológica das lesões dermonecróticas

4.9 Novos estudos sobre o mecanismo de ação das SMases D de Loxosceles 90

4.9.1 Investigação da participação da via de sinalização intracelular MAPK pERK 1/2 no mecanismo de ação das SMase D .90

4.9.2 Ação da SMase I na produção de ROS e RNOS por queratinócitos humanos. .92

4.9.3 Investigação do mecanismo de apoptose em queratinócitos humanos induzido pelas

SMases D.... 
4.9.4 Análise da ação das SMases D sobre a produção de citocinas por queratinócitos

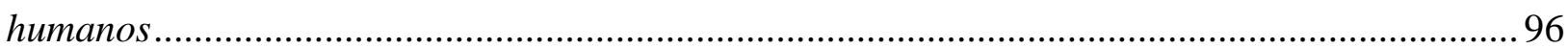

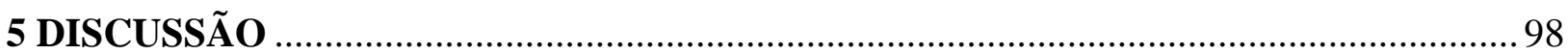

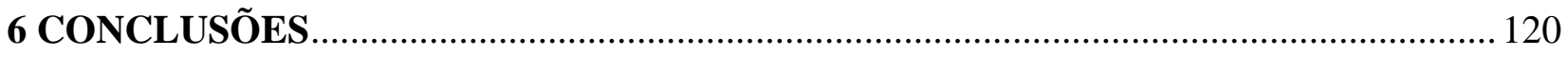

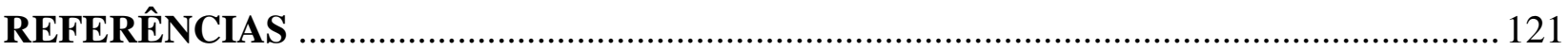




\section{INTRODUÇÃO}

\subsection{Aranhas do gênero Loxosceles e o loxoscelismo}

Aranhas do gênero Loxosceles (Família Sicariidae) são responsáveis por 30,94\% dos 26.143 acidentes por aranhas notificados no Brasil em 2011, sendo que, 28,3\% dos envenenamentos loxoscélicos foram classificados como moderados e graves (SISTEMA DE INFORMAÇÃO DE AGRAVOS DE NOTIFICAÇÃO - SINAN, 2012). Tais agravos ocorrem nas regiões temperadas e tropicais das Américas do Norte, Central e do Sul, África, Ásia e Europa (PLATNICK, 2011; WASSERMAN; ANDERSON, 1983-1984). No Brasil, são três as espécies de importância médica, Loxosceles laeta, L. gaucho e L. intermedia (FUTRELL, 1992), sendo os estados do Paraná e Santa Catarina os mais afetados, com 82,3\% das notificações (SINAN, 2012).

As aranhas pertencentes a este gênero, também conhecidas como aranhas-marrom, possuem hábitos noturnos, são sedentárias e não agressivas (GONÇALVES DE ANDRADE et al., 1999). São animais pequenos, de um $\mathrm{cm}$ de corpo e até três $\mathrm{cm}$ de comprimento total (Figura 1). Apresentam seis olhos de cor branca dispostos aos pares. O cefalotórax não excede em altura ao abdômen, as quelíceras são soldadas na base, movimentando-se em conjunto (LUCAS, 2003) e não ultrapassam $0,45 \mathrm{~mm}$ de comprimento, sendo surpreendente que consigam picar através da pele humana (FUTRELL, 1992). Vivem em locais secos e escuros, embaixo de madeiras ou pedras, em cascas de árvores e cavernas (FISCHER; VASCONCELLOS NETO, 2005; GONÇALVES DE ANDRADE; TAMBOURGI, 2003). No ambiente urbano, são abundantes em áreas peridomiciliares e no interior de residências, escondendo-se atrás de quadros, mobília, roupas ou sapatos, principalmente em regiões de clima frio (FISCHER; VASCONCELLOS NETO, 2005; GONÇALVES DE ANDRADE; TAMBOURGI, 2003; LUCAS, 2003; MÁLAQUE et al., 2002). Os acidentes ocorrem, geralmente, quando as aranhas são comprimidas contra o corpo humano. 
Figura 1 - Exemplares de aranhas Loxosceles laeta
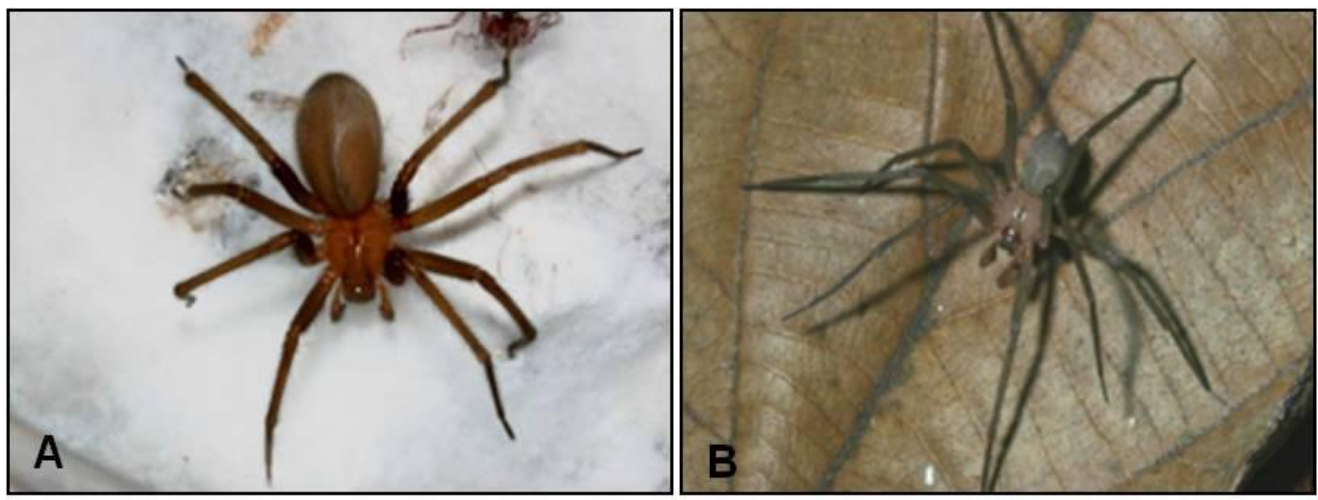

A) L. laeta fêmea. B) L. laeta macho. Fotos: Rogério Bertani e Giuseppe Puorto, Instituto Butantan.

Acredita-se que a quantidade de veneno inoculada durante a picada não ultrapasse 30 $\mu \mathrm{g}$ de proteína (TAMBOURGI et al., 2000), no entanto, resulta em lesões cutâneas necróticas e, menos frequentemente, suscita efeitos sistêmicos. As lesões necróticas levam meses para regredir e, em casos mais graves, os efeitos sistêmicos podem levar a morte (ATKINS et al., 1958). A gravidade dos acidentes sofre influência de uma série de fatores ligados à aranha, como as variações inter- e intraespecíficas do veneno (BARBARO et al., 1996; DE OLIVEIRA et al., 2005; PRETEL et al., 2005; TAMBOURGI et al., 1995), estágio de desenvolvimento (GONÇALVES DE ANDRADE et al., 1999), sexo (DE OLIVEIRA et al., 1999, 2005), quantidade de veneno inoculado (FUTRELL, 1992). Determinadas características do paciente também contribuem como a idade, sexo, local da picada e constituição genética (BARRETO; CARDOSO; DE CILLO, 1985; TAMBOURGI et al., 1998). Nestes acidentes a instalação da necrose é precedida por sinais inflamatórios como edema, espessamento do endotélio vascular, migração e acúmulo de células inflamatórias, vasodilatação, coagulação intravascular, degeneração da parede dos vasos sanguíneos e hemorragia, o que culmina na formação de uma lesão escurecida, com bordas delimitadas, cuja evolução leva a uma úlcera bem demarcada (ATKINS et al., 1958; GERTSCH; ENNIK, 1983; REES; O’LEARY; KING, 1983; TAMBOURGI et al., 1998; TAMBOURGI; GONÇALVES DE ANDRADE; VAN DEN BERG, 2010; WASSERMAN; ANDERSON, 1983-1984).

Dentre os efeitos sistêmicos leves, febre, mal estar, prurido e exantema são comuns; no entanto, em aproximadamente $16 \%$ dos casos considerados graves, hemólise e coagulação intravascular, trombocitopenia e falha renal podem ocorrer (BARRETO; CARDOSO; DE CILLO, 1985; SCHENONE et al., 1989; TAMBOURGI et al., 1998; WHITE; CARDOSO; 
FAN, 1995), sendo estes os principais efeitos do veneno relacionados aos óbitos, os quais ocorrem na sua maioria em crianças e foram associados a espécie Loxosceles laeta (FUTRELL, 1992).

\subsection{Veneno e mecanismos de ação}

Estudando o veneno de Loxosceles reclusa, Forrester et al. (1978) demonstraram a presença de toxinas com atividade esfingomielinásica e, entre os demais componentes do veneno, estas foram foi consideradas um dos mais importantes componentes para o estabelecimento das lesões. Outros componentes foram também identificados como proteases, lipases, fosfatase alcalina, 5-ribonucleotidases, fosfohidrolases (FEITOSA; GRAMSKI; VEIGA, 1998; FUTRELL, 1992; NORMENT; JONG; HEITZ, 1979; PORTARO et al., 1999; REKOW; CIVELLO; GEREN, 1983; VEIGA et al., 2000; WRIGHT et al., 1973), que podem também contribuir para a o estabelecimento do loxoscelismo.

Tambourgi et al. (1995) isolaram do veneno de L. intermedia, por cromatografia de exclusão molecular, uma fração denominada F35 com atividade hemolítica e dermonecrótica. Demonstraram, também, que o sistema complemento desempenhava um importante papel na lise de eritrócitos humanos induzida pelo veneno de Loxosceles e pela F35, uma vez que os componentes de $35 \mathrm{kDa}$ se ligavam à superfície das células, transformando os eritrócitos em ativadores da via alternativa do sistema complemento autólogo. Mostraram, ainda, a presença de proteínas similares a F35 nos venenos de L. laeta e L. gaucho (TAMBOURGI et al., 1995).

A fração F35 foi submetida à cromatografia de fase reversa e o perfil de eluição mostrou três picos contíguos denominados P1, P2 e P3. Duas destas proteínas (P1 e P2) se mostraram dotadas de atividade esfingomielinásica e capazes de induzir os mesmos efeitos do veneno total, como hemólise dependente de complemento e dermonecrose (TAMBOURGI et al., 1998). Estas apresentaram, ainda, homologia com seqüências de toxinas responsáveis por efeitos patológicos do veneno de L. reclusa (CISAR; FOX; GEREN, 1989) e de fatores dermonecróticos, parcialmente purificados dos venenos de L. gaucho (BÁRBARO et al., 1996). Pesquisas em bancos de dados de sequências mostraram que as toxinas das bactérias Corynebacterium pseudotuberculosis e Arcanobacterium haemolyticum também são esfingomielinases e apresentam entre $24-34 \%$ de similaridade com os primeiros 30 aminoácidos das toxinas de Loxosceles (TAMBOURGI et al., 1998), assim como peso molecular e ponto isoelétrico similares (BERNHEIMER; CAMPBELL; FORRESTER, 1985), além disso, as toxinas destas bactérias induzem efeitos biológicos também similares aos 
induzidos pelos venenos de Loxosceles (BERNHEIMER; CAMPBELL; FORRESTER, 1985; FORRESTER; BARRET; CAMPBELL, 1978; McNAMARA; CUEVAS; SONGER, 1995; REES et al., 1984; TAMBOURGI et al., 1998, 2002, 2007).

As fosfolipases são importantes componentes tóxicos presentes em venenos animais e toxinas bacterianas. Elas promovem a hidrólise de ligações éster de fosfolipídios e são classificadas em fosfolipases A1, A2, C e D pela posição da ligação éster hidrolisada (VAN DEN BOSCH, 1980). Em contraste com outras fosfolipases, as encontradas nos venenos de Loxosceles e em certas bactérias possuem uma especificidade de substrato incomum, pois dos quatro principais fosfolipídios presentes em membranas celulares de mamíferos, apenas a esfingomielina é hidrolisada pelas PLD bacterianas, enquanto que as dos venenos das aranhas-marrom clivam esfingomielina gerando como produto de hidrólise ceramida -1fosfato e são capazes, também, de hidrolisar lisofosfatidilcolina, gerando ácido lisofosfatídico (BERNHEIMER; CAMPBELL; FORRESTER, 1985; TAMBOURGI et al., 1998; VAN MEETEREN et al., 2004).

A fração F35, bem como o veneno bruto, quando inoculado em camundongos induziu coagulação intravascular, hemólise e também provocou resposta de citocinas semelhante ao do choque endotóxico, caracterizada pela produção de TNF- $\alpha$, IL-6, IL-10 e do radical NO, no soro de camundongos envenenados (TAMBOURGI et al., 1998a). Outros trabalhos têm mostrado que a migração de células para os tecidos parece ser facilitada pela ação do veneno sobre células endoteliais que passam a produzir citocinas como IL-8 e GM-CSF e que têm aumentada a expressão de moléculas de adesão como a E-selectina (PATEL et al., 1994).

Tambourgi et al. (2000) demonstraram que as toxinas isoladas do veneno de $L$. intermedia tornavam eritrócitos humanos susceptíveis a ação do sistema complemento autólogo, não por interferência sobre os reguladores do complemento ligados à membrana como DAF (Fator de aceleração de decaimento), CR1 (Receptor 1 do complemento) ou CD59, uma vez que a expressão destes não foi alterada na superfície de eritrócitos incubados com as SMases D ou veneno. No entanto, esta incubação induziu a clivagem das porções extracelulares, ricas em ácido siálico, das glicoforinas (A, B e C) da superfície dos eritrócitos, facilitando a ativação da via alternativa do sistema complemento e a hemólise (TAMBOURGI et al., 2000). As glicoforinas são um importante fator na proteção de eritrócitos contra ação do complemento autólogo e a clivagem das mesmas, após incubação dos eritrócitos com veneno ou SMases $\mathrm{D}$, ocorre em sítios próximos à membrana, sendo que tal efeito não é decorrente de uma ação proteolítica direta destas toxinas (TAMBOURGI et al., 2000). Neste estudo, os autores propuseram que a atividade esfingomielinásica das toxinas induz a ativação de 
metaloproteinases endógenas ligadas à membrana, as quais clivam as glicoforinas, facilitando a ativação da via alternativa do complemento (TAMBOURGI et al., 2000).

Mais tarde, Tambourgi et al. (2002) demonstraram que as SMases D também são capazes de induzir a ativação da via clássica do sistema complemento, como demonstrado pela deposição de C1 e C4, na ausência de anticorpos. Esta ativação é, possivelmente, explicada pela alteração no padrão de distribuição dos fosfolipídios na membrana dos eritrócitos. Estudos mostraram que a ativação da via alternativa pode ser induzida por lipossomas contendo fosfolipídios catiônicos (CHONN; CULLIS; DEVINE, 1991; TEST; MITSUYOSHI, 1997), enquanto a via clássica pode ser ativada por fosfolipídios aniônicos (fosfatidilserina) (CHONN; CULLIS; DEVINE, 1991). A análise dos eritrócitos incubados com as SMases D, quanto à expressão de fosfatidilserina na superfície, usando Anexina V que tem alta afinidade de ligação pela fosfatidilserina na presença de cálcio (ERNST, 1993; RAYNAL; POLLARD, 1994; TAIT; GIBSON, 1994), mostrou que hemácias que haviam sofrido a ação esfingomielinásica das toxinas perdiam a assimetria da membrana, expondo fosfatidilserina na camada externa, o que parece facilitar a iniciação da ativação da via clássica do complemento (TAMBOURGI et al., 2002). Tal mecanismo de ativação da via clássica foi posteriormente elucidado, mostrando que C1q se liga diretamente à superfície de eritrócitos iniciando, assim, a ativação e que reguladores solúveis do complemento, como proteína ligante de $\mathrm{C} 4 \mathrm{~b}(\mathrm{C} 4 \mathrm{bp})$ e fator $\mathrm{H}$, não foram capazes de prevenir a hemólise (TAMBOURGI et al., 2007). Adicionalmente, a ação das esfingomielinases na superfície dos eritrócitos e a formação de ceramida-1-fosfato, lipídio que tal qual a fosfatidilserina, tem forte carga negativa, pode também facilitar a ligação de C1q ao eritrócito (TAMBOURGI et al., 2007). Portanto, no que diz respeito à indução de sintomas sistêmicos, o sistema complemento em associação aos efeitos diretos do veneno parece contribuir para a patologia.

Quanto às lesões locais, os leucócitos polimorfonucleares (PMN) parecem contribuir para o desenvolvimento da necrose, uma vez que foi demonstrado que em animais depletados de sistema complemento, o influxo de neutrófilos era diminuído e a lesão dermonecrótica reduzida; no entanto, dissociação das fibras colágenas, degeneração de fibras musculares e hemorragia ainda persistiam na derme (TAMBOURGI et al., 2005). Experimentos in vitro mostraram que o veneno induz a expressão de citocinas como TNF- $\alpha$, IL-8 e VEGF em culturas primárias de queratinócitos, células HL60, HUVECS e células epiteliais pulmonares, sugerindo que estas possam também contribuir para o recrutamento de PMN (DESAI et al., 2000; MÁLAQUE; SANTOS; ANDRADE, 1999; PATEL et al., 1994). 
Estudos sobre a ação das SMases D de Loxosceles sobre eritrócitos e células nucleadas demonstraram que estas toxinas induzem a ativação de metaloproteinases ligadas à membrana (TAMBOURGI et al., 2000; VAN DEN BERG et al., 2002). Posteriormente, Tambourgi et al. (2005) mostraram também que, em coelhos, a SMase D era capaz de induzir a expressão da metaloproteinase de matriz extracelular - 9 (MMP-9), a qual é possivelmente um dos fatores cruciais envolvidos na patogênese das lesões locais.

Os PMN são uma das principais fontes de liberação de MMP-9 na corrente sanguínea em resposta a estímulos como LPS, TNF- $\alpha$, IL-8 e GM-CSF. Além das MMPs secretadas por PMNs, a ativação de metaloproteinases associadas à superfície celular foi detectada em células endoteliais tratadas com veneno (VAN DEN BERG et al., 2002). Por outro lado, as metaloproteinases de matriz extracelular parecem estar envolvidas na progressão da lesão dermonecrótica, como demonstrado pela ação das esfingomielinases sobre a pele de coelhos e sobre queratinócitos humanos em cultura (PAIXÃO-CAVALCANTE et al., 2006; TAMBOURGI et al., 2005). Assim, foi mostrada uma relação positiva entre o aumento na expressão das MMP 2/9 e a apoptose e que, além dos queratinócitos, fibroblastos e neutrófilos contribuíam para a secreção destas proteases (PAIXÃO-CAVALCANTE et al., 2006; TAMBOURGI et al., 2005).

O uso da Tetraciclina que, em adição à sua propriedade antibiótica, é também capaz de inibir MMPs, se mostrou eficaz em proteger os queratinócitos humanos, inibindo a secreção de MMP-2 e 9 e a perda da viabilidade celular induzida pelo veneno (PAIXÃOCAVALCANTE et al., 2006), sendo que tal tratamento foi também capaz de reduzir a progressão da lesão dermonecrótica (PAIXÃO-CAVALCANTE et al., 2007).

Quanto ao tratamento, a soroterapia é amplamente utilizada no Brasil, no entanto não existe consenso quanto à sua eficácia, uma vez que parece não apresentar grandes benefícios no que diz respeito aos seus efeitos sobre as lesões locais (BRASIL, 2001). De Almeida et al. (2008) demonstraram que o soro produzido contra esfingomielinases D recombinantes das espécies L. laeta (SMase I) e L. intermedia (P1 e P2) era capaz de neutralizar eficientemente as atividades dos venenos homólogos e de L. gaucho. Este antissoro foi mais eficaz na neutralização do que o soro antiaracnídico, utilizado terapeuticamente no Brasil e produzido a partir dos venenos de L. gaucho (21,5\%), Phoneutria nigriventer (21,5\%) e Tityus serrulatus (57\%). Tratamentos com corticosteróides e outros medicamentos têm sido usados, mas também sem grande sucesso ou com efeitos colaterais indesejados (ELSTON et al., 2005). 


\subsection{Estrutura das SMases D}

As esfingomielinases D são os componentes centrais para o desenvolvimento dos efeitos tóxicos induzidos pelo veneno de Loxosceles, sendo, desta forma, imprescindível a identificação de elementos estruturais da proteína, bem como sua contribuição para o mecanismo de ação. No entanto, a dificuldade em se obter quantidades suficientes de veneno, para as etapas de purificação, era um fator limitante.

Fernandes-Pedrosa et al. (2002) clonaram e expressaram uma SMase D, denominada SMase I, a partir da glândula de veneno de Loxosceles laeta; tal molécula é composta por 311 resíduos de aminoácidos, sendo a proteína madura correspondente à região dos resíduos 1 a 281 (Figura 2).

Figura 2 - Sequencia deduzida de aminoácidos da SMase I de L. laeta (número de acesso: AY093599; Fernandes-Pedrosa et al., 2002)

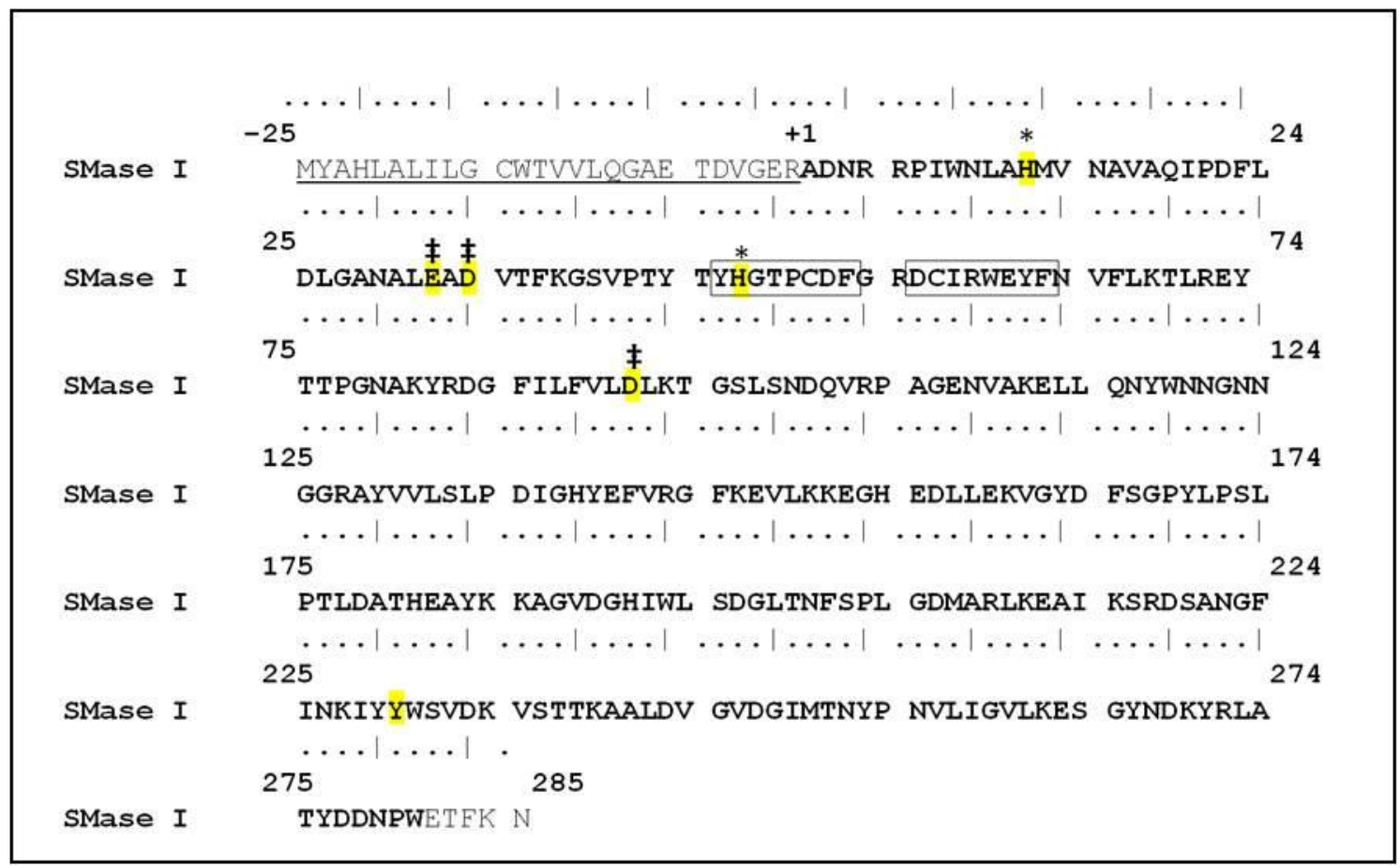

Os resíduos sublinhados correspondem à região do peptídeo sinal. A proteína madura compreende a região de +1 a 281, marcada em negrito. Os resíduos do sítio ativo estão marcados em amarelo. Os retângulos indicam os resíduos da região do loop catalítico. + indica os resíduos importantes para a região de ligação do íon $\mathrm{Mg}^{+2} ; *$ indicam os resíduos de Histidina nas posições 12 e 47, importantes para a catálise.

A análise da estrutura secundária da SMase I de L. laeta, por dicroísmo circular, revelou que a toxina possui $38 \%$ de $\alpha$-hélices, $13,8 \%$ de folhas- $\beta, 10,6 \%$ de $\beta$-turn e $38 \%$ de 
random coil, sendo que tais dados são consistentes com os dados obtidos por análises bioinformáticas (Figura 3) (DE ANDRADE et al., 2005). A estrutura secundária $\alpha / \beta-$ fold mostrada por esta toxina é semelhante a aquela presente nas proteínas da família das Fosfolipases D (PLD) (DE ANDRADE et al., 2005).

Figura 3 - Predição da estrutura secundária da SMase I de L. laeta
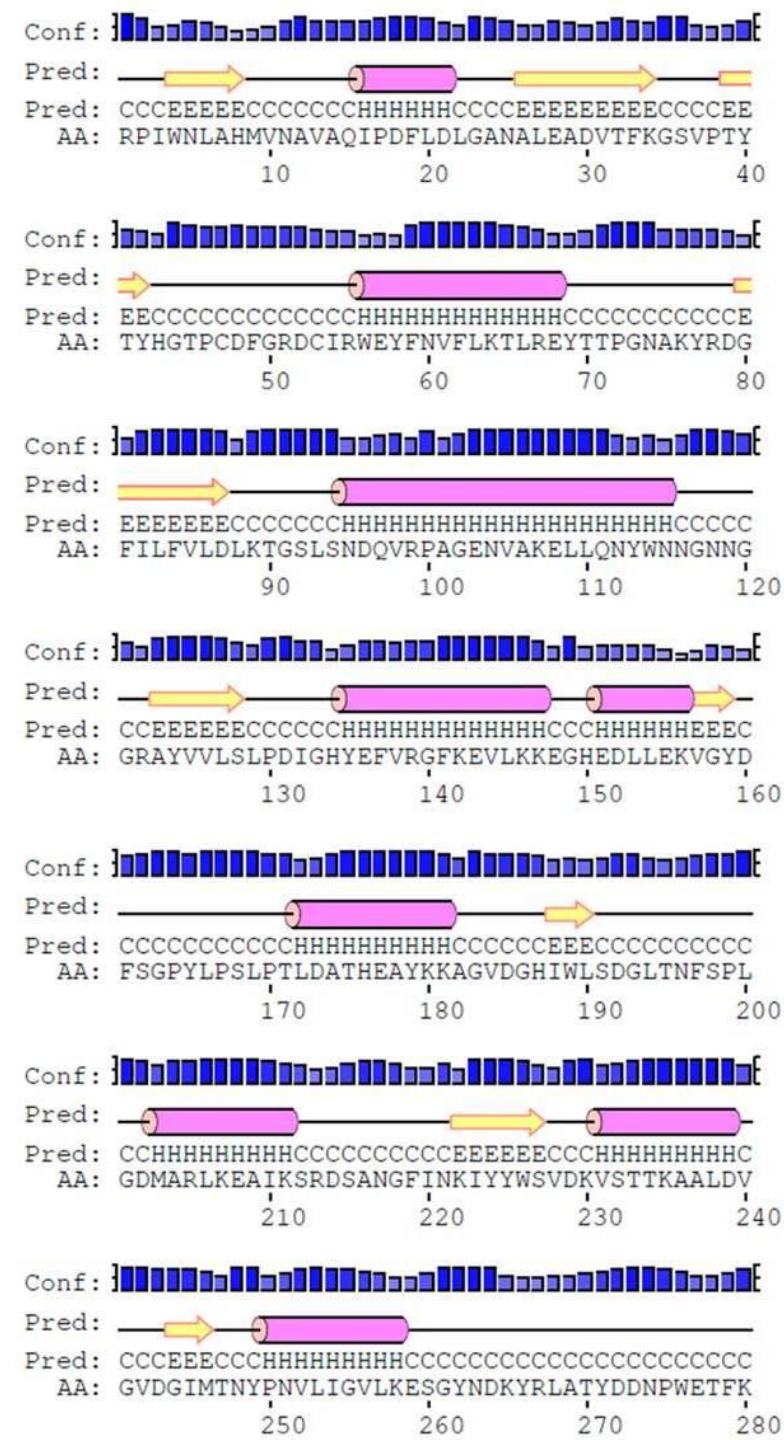

A análise da estrutura secundária foi realizada com os programas PSIPRED (Position Specific Iterated Prediction) (JONES, 1999) e GOR4 (Secondary structure prediction) (GARNIER et al., 1996). Os cilindros rosa representam $\alpha$-hélices e as setas amarelas representam as folhas $\beta$, enquanto os random coil estão representados por um traço preto.

Segundo De Andrade et al. (2005), a estrutura secundária da SMase I é afetada de maneira irreversível pela acidificação ou alcalinização da solução, bem como por condições 
de temperatura superiores a $80^{\circ} \mathrm{C}$. Tais modificações estruturais comprometem a habilidade da enzima em induzir hemólise dependente do sistema complemento e dermonecrose, sendo que alterações de $\mathrm{pH}$ reduzem a atividade da enzima e o aquecimento leva a completa inativação da mesma. A isoforma inativa (P3) de SMase D, isolada do veneno de $L$. intermedia, apresenta um menor conteúdo de $\alpha$-hélices em relação às demais isoformas. Tal diferença estrutural poderia afetar a interação do sítio ativo desta proteína com o substrato, o que explicaria a ausência de atividade, sugerindo uma correlação positiva entre conteúdo de $\alpha$-hélices e a atividade biológica das SMases D de Loxosceles (DE ANDRADE et al., 2005).

Utilizando a toxina recombinante, Murakami et al. (2005) mostraram que a SMase I se dobra para formar um "barril" $(\alpha / \beta)_{8}$ distorcido, com a inserção de folhas- $\beta$ e $\alpha$-hélices adicionais e diversos loops de ligação (catalítico, variável e flexível). Estes, juntamente com outros loops hidrofóbicos, formam o lado interfacial da enzima onde o sítio catalítico está localizado em uma fenda rasa. O loop catalítico contém um resíduo importante para o mecanismo de hidrólise, a His47, que é conservada nas SMases D, formando um "grampo" que é orientado em relação a parte central da enzima por pontes dissulfeto e redes de pontes de hidrogênio (Figura 4). A ligação ao substrato e/ou estado de transição são estabilizados pelo íon $\mathrm{Mg}^{+2}$, que é coordenado pelos resíduos $\mathrm{Gly}^{32}, \mathrm{Asp}^{34}, \mathrm{Asp}^{91}$ e moléculas solventes. $\mathrm{O}$ sítio catalítico contém, ainda, resíduos altamente conservados $\left(\mathrm{His}^{12}, \mathrm{Glu}^{32}, \mathrm{Asp}^{34}, \mathrm{Asp}^{91}\right.$, $\mathrm{His}^{47}, \mathrm{Asp}^{52}, \operatorname{Trp}^{230}, \mathrm{Asp}^{233}$ e $\mathrm{Asn}^{252}$ ) nas diversas isoformas de SMases D de Loxosceles (MURAKAMI et al., 2005). O sítio de ligação ao $\mathrm{Mg}^{+2}$, juntamente com $\operatorname{Tr}^{230}$, Lys ${ }^{93}$ e os dois resíduos catalíticos ( $\mathrm{His}^{12}$ e $\mathrm{His}^{47}$ ), formam o bolsão do sítio ativo, que é conservado nas SMases D bacterianas e de venenos de aranhas (MURAKAMI et al., 2005) (Figura 4). 
Figura 4 - Representação esquemática da estrutura terciária da SMase I de L. laeta

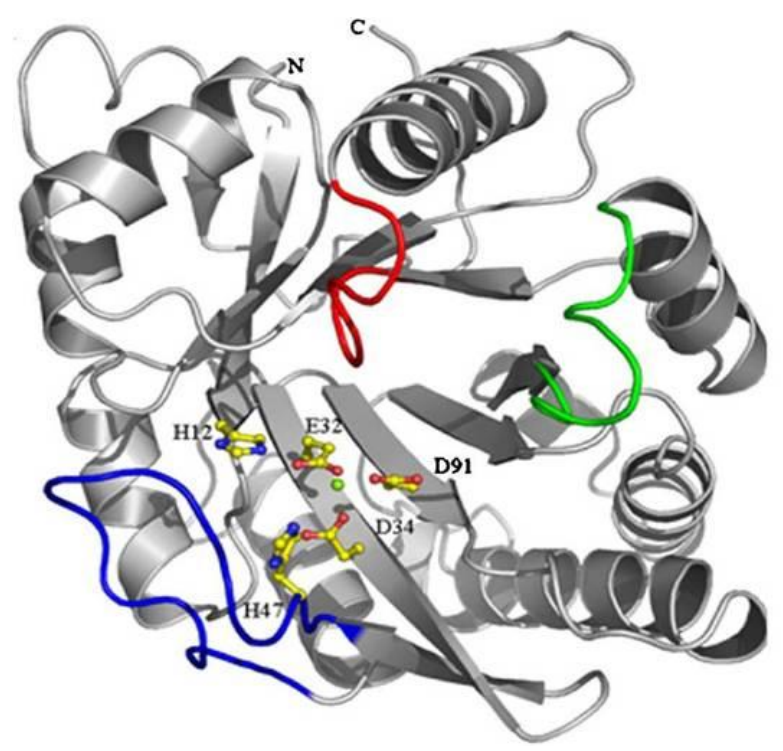

Os aminoácidos envolvidos na ligação do íon metal e na catálise estão representados como átomos coloridos. Os loops catalítico, flexível e variável estão representados em azul, vermelho e verde, respectivamente.

Fonte: Murakami et al. (2006).

Murakami et al. (2005) propuseram um mecanismo catalítico baseado em uma reação ácido-base combinada, com estabilização por íons metálicos $\left(\mathrm{Mg}^{+2}\right)$. Tal mecanismo está fundamentado em um ataque nucleofílico direto da molécula de água, em uma maneira análoga aos mecanismos propostos para desoxiribonuclease I (JONES; WORRAL; CONNOLLY, 1996; SUCK; OEFNER, 1986; SUCK; LAHM; OEFNER, 1988), PLD (LEIROS; MCSWEENEY; HOUGH, 2004; STUCKEY; DIXON, 1999) e outros (MATSUO et al., 1996). Neste modelo, a ação conjunta de duas Histidinas ( $\mathrm{His}^{12}$ e His ${ }^{47}$ ) é requerida para a catálise. His ${ }^{12}$ funciona como o nucleófilo que inicia o ataque sobre a ligação fosfodiester do substrato esfingomielina, seguido pela formação de intermediários, os quais são desestabilizados pela doação de um átomo do hidrogênio pela $\mathrm{His}^{47}$, para produzir colina. $\mathrm{O}$ intermediário da reação é estabilizado por uma ligação covalente entre His ${ }^{12} \mathrm{~N}^{\epsilon 2}$. Por causa da doação de um próton pela His ${ }^{47}$, esta é agora capaz de desprotonar uma molécula de água vizinha, que inicia o ataque nucleofílico sobre a histidina intermediária estável, assim resultando na formação do segundo produto, ceramida-1-fosfato (MURAKAMI et al., 2005).

Murakami et al. (2006) mostraram que o papel dos resíduos de Histidina (His ${ }^{12}$ e $\mathrm{His}^{47}$ ), propostos no modelo anterior, é invertido, ou seja, a $\mathrm{His}^{47}$, se comporta como o nucleófilo que inicia o processo de hidrólise, pelo ataque à ligação fosfodiester do substrato. A doação de um átomo de hidrogênio pela His ${ }^{12}$ leva à formação da colina. A Histidina 
desprotonada é, agora, capaz de seqüestrar um próton da molécula solvente, i.e, água, que inicia o ataque sobre um intermediário da reação, resultando na formação de ceramida-1fosfato. Ainda neste estudo, os autores revelaram, por meio de modelagem molecular, que as características estruturais importantes para a catálise estão altamente conservadas nas classes de SMases D. Demonstraram também a existência de uma relação evolutiva entre essas enzimas e as glicerofosfodiéster-fosfodiesterase, as quais utilizam um mecanismo catalítico semelhante (MURAKAMI et al., 2006).

\subsection{Docking molecular}

Estudos de Docking molecular têm ganhado espaço em diversos campos como imunologia (KUMAR et al., 2011; RAHMAN et al., 2011), virologia, medicina (ALLER et al., 2011; YANG; SALAM; ROSEN, 2011), farmacologia, bioquímica, entre outros. No entanto, contribuições relevantes destes estudos têm sido dadas ao desenvolvimento de novos fármacos antibacterianos e inibidores enzimáticos (DEY; CHEN, 2011; KIRCHMAIR et al., 2011; KOTHANDAN et al., 2011; YIN et al., 2011).

Docking molecular é o estudo de como duas ou mais estruturas se encaixam, ou seja, é utilizado para prever, in silico, a estrutura de um complexo intermolecular formado entre duas ou mais moléculas. Os diferentes métodos utilizados nos estudos de docking envolvem funções de scores de energia, que basicamente descrevem as interações estéricas, eletrostáticas, de ligações de hidrogênio e hidrofóbicas, que classificam as melhores posições de ligação (orientação e conformação) do ligante no sítio receptor determinado na molécula alvo. Para estes estudos, os métodos envolvem duas etapas: (a) escolha do algoritmo de busca, o qual deve criar um grande número de configurações, incluindo os modos de ligação determinados experimentalmente para as moléculas; (b) avaliação das configurações e modos de ligação, por meio de scores que distingam os modos de ligação determinados experimentalmente e os determinados pelo algoritmo de busca, classificando as moléculas de acordo com suas propriedades de afinidade de ligação (KAAPRO; OJANEM, 2002; VERDONK et al., 2003).

Uma das principais características de um bom programa de Docking é a capacidade de reproduzir os modos de ligação determinados experimentalmente e a capacidade de selecionar virtualmente moléculas em grandes bibliotecas de compostos. Outro ponto relevante é a habilidade de atribuir scores e classificar os ligantes de acordo com sua afinidade de ligação (VERDONK et al., 2003). Alguns dos softwares mais utilizados para estes estudos são o 
DOCK (MAKINO; KUNTZ, 1997), FlexX (RAREY et al., 1996), PRO_LEADS (BAXTER et al., 1998) e GOLD (JONES; WILLET; GLEN, 1995; JONES et al., 1997), mas a literatura dispõe de muitos outros (TAYLOR; JEWSBURY; ESSEX, 2002).

Atualmente, o desenvolvimento de novos fármacos, com base na estrutura tridimensional de macromoléculas alvo e no mecanismo de ação, é uma das estratégias menos dispendiosa e eficiente. $\mathrm{O}$ uso da modelagem molecular neste processo pode auxiliar em todas as etapas, desde a descoberta, otimização, até a seleção de compostos candidatos a estudos clínicos (OPREA, 2005). Sabendo-se que o sítio ativo de enzimas exibe alta seletividade no reconhecimento de moléculas, a busca por pequenos compostos que, no caso da SMase D de Loxosceles, sejam capazes de bloquear a atividade da enzima, por meio das técnicas de docking molecular e modelagem parece ser uma estratégia interessante na pesquisa pela melhora da eficiência do tratamento dos acidentes, bem como no desenvolvimento de ferramentas que auxiliem no estudo dos mecanismos de ação do veneno. 


\section{OBJETIVOS}

\subsection{Objetivo geral}

O presente projeto tem como objetivo avaliar a eficácia de inibidores sintéticos de SMases D, desenhados por meio de estudos de docking molecular, em modelos experimentais de loxoscelismo cutâneo e sistêmico, bem como investigar os mecanismos de sinalização intracelular e novos mecanismos de ação desencadeados pela toxina. Para tal, foram propostos os seguintes objetivos específicos:

\subsection{Objetivos específicos}

Investigar o efeito dos inibidores sobre a atividade hidrolítica do veneno e da SMase D sobre esfingomielina e lisofosfatidilcolina;

Investigar o efeito dos inibidores sobre os mecanismos de hemólise, dependente de complemento, induzidos pelo veneno/SMase $\mathrm{D}$, em ensaios in vitro;

$\checkmark \quad$ Investigar o efeito dos inibidores sobre a ação tóxica do veneno/SMase D em queratinócitos humanos;

$\checkmark \quad$ Caracterizar o padrão de secreção de citocinas e produção de ROS em queratinócitos humanos tratados com veneno/SMases $\mathrm{D}$ e a possível modulação pelo uso de inibidores;

Investigar o efeito dos inibidores sobre a indução da dermonecrose em modelo experimental, usando coelhos;

$\checkmark \quad$ Investigar o efeito dos inibidores no modelo murino de loxoscelismo sistêmico, avaliando a toxicidade letal do veneno;

Investigar os mecanismos de ação e sinalização intracelular, mediados pelas veneno/SMases D em queratinócitos humanos in vitro. 


\section{MATERIAL E MÉTODOS}

\subsection{Veneno de $L$. laeta}

O veneno da aranha L. laeta foi fornecido pelo Biotério de Aranhas do Laboratório de Imunoquímica do Instituto Butantan. O veneno foi obtido por eletroestimulação, segundo o método de Burcherl (1969), com algumas modificações. Estímulos elétricos de 15-20 volts foram repetidamente aplicados no esterno das aranhas e as gotas de veneno coletadas com uma micropipeta e preparadas em solução PBS estéril $\left(8,1 \mathrm{mM} \mathrm{Na} \mathrm{HPO}_{4} ; 1,5 \mathrm{mM} \mathrm{K \textrm {K } _ { 2 }} \mathrm{PO}_{4}\right.$; $137 \mathrm{mM} \mathrm{NaCl} ; 2,7 \mathrm{mM} \mathrm{KCl}, \mathrm{pH} 7,4)$. O veneno foi aliquotado e estocado a $-20{ }^{\circ} \mathrm{C} . \mathrm{O}$ conteúdo protéico das amostras foi determinado utilizando o kit BCA "Protein Assay Kit" (Pierce Biotechnology, IL, EUA).

\subsection{Expressão e purificação da SMase I de L. laeta}

Colônias de bactérias E. coli BL21 ( $\mathrm{DE}_{3}$ ) (Invitrogen Corp., CA, EUA), transformadas com o vetor de expressão pAE contendo o gene correspondente à Esfingomielinase D I (SMase I) de L. laeta (FERNANDES-PEDROSA et al., 2002), foram incubadas em meio 2YT contendo ampicilina e crescidas a $37{ }^{\circ} \mathrm{C}$ até a $\mathrm{DO}_{600} 0,6$. A expressão gênica foi induzida pela adição de $5 \mathrm{mM}$ de IPTG (Isopropyl $\beta$-D-1-thiogalactopyranoside - Invitrogen Corp., CA, EUA) e $5 \mathrm{mM}$ de glicose ao meio. Após a indução, as bactérias foram lisadas por sonicação e as suspensões centrifugadas a $10.000 \mathrm{rpm}$ durante 60 minutos a $4{ }^{\circ} \mathrm{C}$. O sobrenadante foi submetido à cromatografia de afinidade em coluna ProBond ${ }^{\mathrm{TM}}$ Nickel- $^{-}$ Chelating Resin (Invitrogen Corp., CA, EUA). O material não adsorvido foi eluído por lavagens com tampão fosfato de sódio $\left(\mathrm{Na}_{3} \mathrm{PO}_{4} 0,02 \mathrm{M}, \mathrm{NaCl} 0,5 \mathrm{M}\right) \mathrm{pH} 7,8$ e as proteínas recombinantes, adsorvidas à coluna, foram eluídas em tampão fosfato de sódio $\mathrm{pH}$ 6,0, contendo concentrações crescentes de imidazol (60 mM a 0,8 M). As esfingomielinases recombinantes eluídas foram concentradas em Amicon 30.000 MW (Millipore, MA, EUA) e o conteúdo proteico determinado utilizando-se o método de Lowry et al. (1951). As amostras foram aliquotadas e estocadas a $-80^{\circ} \mathrm{C}$ até o momento do uso. 


\subsection{Análise da presença de endotoxina nas amostras de veneno e toxina recombinante}

Amostras do veneno de L. laeta $(10 \mu \mathrm{g})$ e da toxina recombinante $(10 \mu \mathrm{g})$ foram diluídas em água apirogênica e encaminhadas à Seção de Controle Microbiológico (Serviço de controle de qualidade, Divisão Bioindustrial) do Instituto Butantan para análise da presença de endotoxina. A análise foi realizada pelo método de LAL (Limulus amebocyte lisate) utilizando o Kit PYROGENT ${ }^{\mathrm{TM}}$ Gel clot LAL Assays (Lonza, Walkersville, MD, USA), de acordo com as especificações do fabricante. A concentração de endotoxina presente nas amostras foi calculada de acordo com uma curva padrão de endotoxina de E. coli com concentrações de 2,5 a $0,125 \mathrm{UE} / \mathrm{mL}$.

\subsection{Animais experimentais}

Neste estudo foi necessário o uso de dois modelos animais. Para os ensaios de letalidade foram utilizados camundongos da linhagem Balb/c, machos com peso entre 18-22 g e uma vez que camundongos não desenvolvem a lesão dermonecrótica quando injetados com veneno de Loxosceles, foram então utilizados coelhos albinos New Zealand, machos, pesando $3 \mathrm{~kg}$. Os animais foram fornecidos pelo Biotério Central do Instituto Butantan e mantidos durante os ensaios no Biotério do Laboratório de Imunoquímica com livre acesso a água e ração. O projeto foi submetido para avaliação da Comissão de Ética no Uso de Animais do Instituto Butantan e aprovado sob protocolo n. ${ }^{\circ}$ 805/11, bem como à Comissão de Ética no Uso de Animais do Instituto de Ciências Biomédicas-USP, registrado como no 126, fls. 134 do livro 2.

\subsection{Análise eletroforética do veneno de L. laeta e da toxina recombinante}

O perfil eletroforético das amostras de veneno de L. laeta e de amostras de SMase D recombinante foi analisado por SDS-PAGE, como descrito por Laemmli (1970) em gel de poliacrilamida a $12 \%$. Amostras preparadas em condições não-redutoras foram aplicadas no gel, a corrida foi realizada em voltagem constante de 100 volts e à temperatura ambiente. Para a estimativa da massa molecular dos componentes das amostras, foi utilizado um padrão de massa molecular (Mr) contendo componentes proteicos pré-corados, com Mrs entre 6 a 180 kDa (BenchMark Pre Stained Protein Ladder - Invitrogen Corp.). As proteínas presentes nas amostras foram reveladas pela impregnação com nitrato de prata (MORRISSEY, 1980). 


\subsection{Caracterização das atividades do veneno de $L$. laeta e da toxina recombinante}

\subsubsection{Atividade hidrolítica}

A atividade esfingomielinásica do veneno e da toxina recombinante foi determinada pelo método de Tokumura et al. (2002). Resumidamente, amostras de veneno (10 $\mu \mathrm{g})$ e da toxina $(2,5$ e $5 \mu \mathrm{g})$ foram incubadas, por 30 minutos a $37{ }^{\circ} \mathrm{C}$, com os substratos esfingomielina (SM - $50 \mu \mathrm{M}$, diluída em tampão Hepes-Salina pH 7,4 - NaCl 140 mM, KCl 5 $\mathrm{mM}, \mathrm{CaCl}_{2} 1 \mathrm{mM}, \mathrm{MgCl}_{2} 1 \mathrm{mM}$, Hepes $10 \mathrm{mM}$ ) ou lisofosfatidilcolina (LPC - $50 \mu \mathrm{M}$, diluída em tampão Hepes-Salina pH 7,4 contendo BSA $2 \mathrm{mg} / \mathrm{mL}$ ). Posteriormente, $10 \mu \mathrm{L}$ da mistura composta por colina oxidase $(1$ unidade $/ \mathrm{mL})$; peroxidase $(0,06$ unidade $/ \mathrm{mL})$ e $50 \mu \mathrm{M}$ de ácido 3-(4-hidroxil-fenil) propiônico, em tampão Hepes-Salina pH 7,4, foram adicionados e a reação prosseguiu por mais 10 minutos a $37{ }^{\circ} \mathrm{C}$. Após esse período, a colina formada foi oxidada à betaína e mensurada a $\lambda 320 \mathrm{~nm}$ (excitação) e $\lambda 405 \mathrm{~nm}$ (emissão), em espectrofluorímetro de placa VICTOR ${ }^{\mathrm{TM}}$ (Perkin-Elmer, CA, EUA).

\subsubsection{Atividade hemolítica dependente de complemento}

\subsubsection{Obtenção de eritrócitos}

Para a obtenção de eritrócitos, sangue humano foi coletado de doadores sadios em solução anticoagulante de Álsever (v/v) (Citrato 114 mM, glicose 27 mM, NaCl 72 mM, pH $6,1)$. A solução foi mantida a $4{ }^{\circ} \mathrm{C}$ até o momento do uso. $\mathrm{O}$ projeto foi submetido à Comissão de Ética em Pesquisa com Seres Humanos do Instituto de Ciências Biomédicas da Universidade de São Paulo e aprovado como parecer $n^{\circ} 1088$.

\subsubsection{Tratamento dos eritrócitos humanos}

Um volume de eritrócitos humanos a 1,5\% foi lavado por três vezes em tampão PBS pH 7,4 e ressuspendido em tampão $\mathrm{VBS}^{2+}$ (2,8 mm ácido barbitúrico, 145,5 mM NaCl, 0,8 $\mathrm{mM} \mathrm{MgCl}_{2}, 0,3 \mathrm{mM} \mathrm{CaCl}_{2}, 0,9 \mathrm{mM}$ Na-barbital, $\mathrm{pH}$ 7.2). Um mililitro da suspensão de eritrócitos foi incubado com igual volume de tampão $\mathrm{VBS}^{2+}$ contendo veneno de $L$. laeta/SMase I, durante 30 minutos a $37{ }^{\circ} \mathrm{C}$ sob agitação. Amostras tratadas apenas com tampão $\mathrm{VBS}^{2+}$ foram utilizadas como controles. 


\subsubsection{Ensaio hemolítico}

Às placas de 96 poços com fundo em $\mathrm{U}$, foram adicionadas aliquotas de $100 \mu \mathrm{L}$ dos eritrócitos humanos, tratados como descrito acima, e $100 \mu \mathrm{L}$ de soro humano normal (SHN), diluído 1:2 em tampão $\mathrm{VBS}^{2+}$. Após a incubação por 1 hora a $37{ }^{\circ} \mathrm{C}$, as amostras foram centrifugadas a $1.500 \mathrm{rpm}$ durante 3 minutos e a $4{ }^{\circ} \mathrm{C}$. Amostras de $150 \mu \mathrm{L}$ dos sobrenadantes foram transferidas para placa de fundo chato e a hemólise foi mensurada a $\lambda 414 \mathrm{~nm}$ e expressa em porcentagem. A lise espontânea ou total dos eritrócitos humanos foi avaliada em amostras de células incubadas com $\mathrm{VBS}^{2+}$ ou $\mathrm{H}_{2} \mathrm{O}$, respectivamente.

\subsection{Ação do veneno de $L$. laeta e SMase I sobre queratinócitos humanos: viabilidade celular}

\subsubsection{Cultivo de células HaCat}

Células da linhagem HaCat de queratinócitos humanos foram cultivadas em garrafas de $75 \mathrm{~cm}^{2}$ (Corning Inc. - NY, EUA) contendo meio DMEM (Dulbecco's Modified Eagle Medium - Gibco, Invitrogen Corp., CA, EUA) suplementado com 10\% de soro fetal bovino (SFB - Cultilab, SP, Brasil) e 1\% de penicilina-estreptomicina (Gibco, Invitrogen Corp.), em estufa a $37^{\circ} \mathrm{C}$ e $5 \% \mathrm{CO}_{2}$.

\subsubsection{Ensaio com MTT}

A ação do veneno bruto e da toxina recombinante sobre a viabilidade de queratinócitos humanos foi avaliada pelo método do MTT (3-(4, 5-dimethylthiazol-2-yl)-2,5-diphenyltetrazolium bromide) (MOSMANN, 1983). Para tanto, queratinócitos $\left(5 \times 10^{4}\right.$ células/poço) foram cultivados em placas de 96 poços contendo meio DMEM suplementado e, posteriormente, mantidas por 24 horas em meio DMEM sem SFB. Após este período, as células foram incubadas por 24, 48 e 72 horas com amostras de $10 \mu \mathrm{g}$ de veneno ou $5 \mu \mathrm{g}$ da toxina recombinante em estufa a $37{ }^{\circ} \mathrm{C}$ e $5 \% \mathrm{CO}_{2}$. Ao fim dos períodos de incubação, o sobrenadante dos poços foi aspirado, foram adicionados $60 \mu \mathrm{L} /$ poço da solução de MTT $(0,83$ $\mu \mathrm{g} / \mu \mathrm{L})$, em meio DMEM incompleto, e as placas incubadas por 30 minutos a $37{ }^{\circ} \mathrm{C}$ e $5 \%$ $\mathrm{CO}_{2}$. A seguir, o sobrenadante foi aspirado, $100 \mu \mathrm{L} /$ poço de DMSO (Dimetilsulfóxido Merck - Darmstad, Alemanha) foram adicionados e as placas ficaram em repouso à 
temperatura ambiente por cinco minutos, antes da leitura em leitor de placas (Multiskan-EX, Labsystems, Helsinki, Finlândia), nos comprimentos de onda de $\lambda 540$ e $\lambda 620$ nm. A viabilidade celular foi calculada pela fórmula:

[(D.O. amostra $(540-620 \mathrm{~nm}) \times 100]$

[(média da D.O. controle $(540-620 \mathrm{~nm}))]$

\subsection{Seleção de Compostos inibidores de SMases D}

\subsubsection{Seleção dos ligantes}

Os ligantes utilizados no presente estudo foram selecionados de um banco de dados de moléculas comercialmente disponíveis, o ZINC Database (IRWIN et al., 2012). Muitos dos ligantes deste banco estão disponíveis em muitos formatos 3D que podem ser utilizados por vários programas de docking. Além das propriedades físico-químicas importantes, o banco contém informações de fornecedores e números de catálogo para cada fonte comercial do

composto. É possível encontrar também informações sobre função ou atividades já testadas para o composto, quando disponíveis (IRWIN; SCOICHET, 2005).

\subsubsection{Docking molecular}

Estudos de docking molecular, para a seleção de inibidores de SMases D, foram conduzidos pelo Dr. Mário Murakami do Laboratório Nacional de Luz Síncroton, Campinas São Paulo, com o auxílio de softwares ICM - Molsoft (baseado no algoritmo de Monte Carlo), Molegro Virtual Docker (baseado em um algoritmo de busca que combina evolução diferencial com um algoritmo de predição de cavidade) e GOLD (baseado em um agorítimo genético). As análises de docking foram realizadas com base na estrutura terciária da SMase I do veneno de L. laeta (MURAKAMI et al., 2006) e a região da molécula correspondente ao sítio de ancoragem dos ligantes está mostrada na figura 5. 
Figura 5 - Resíduos de aminoácidos da molécula de SMase I indicados como sítio de ligação para os ligantes estudados no docking molecular

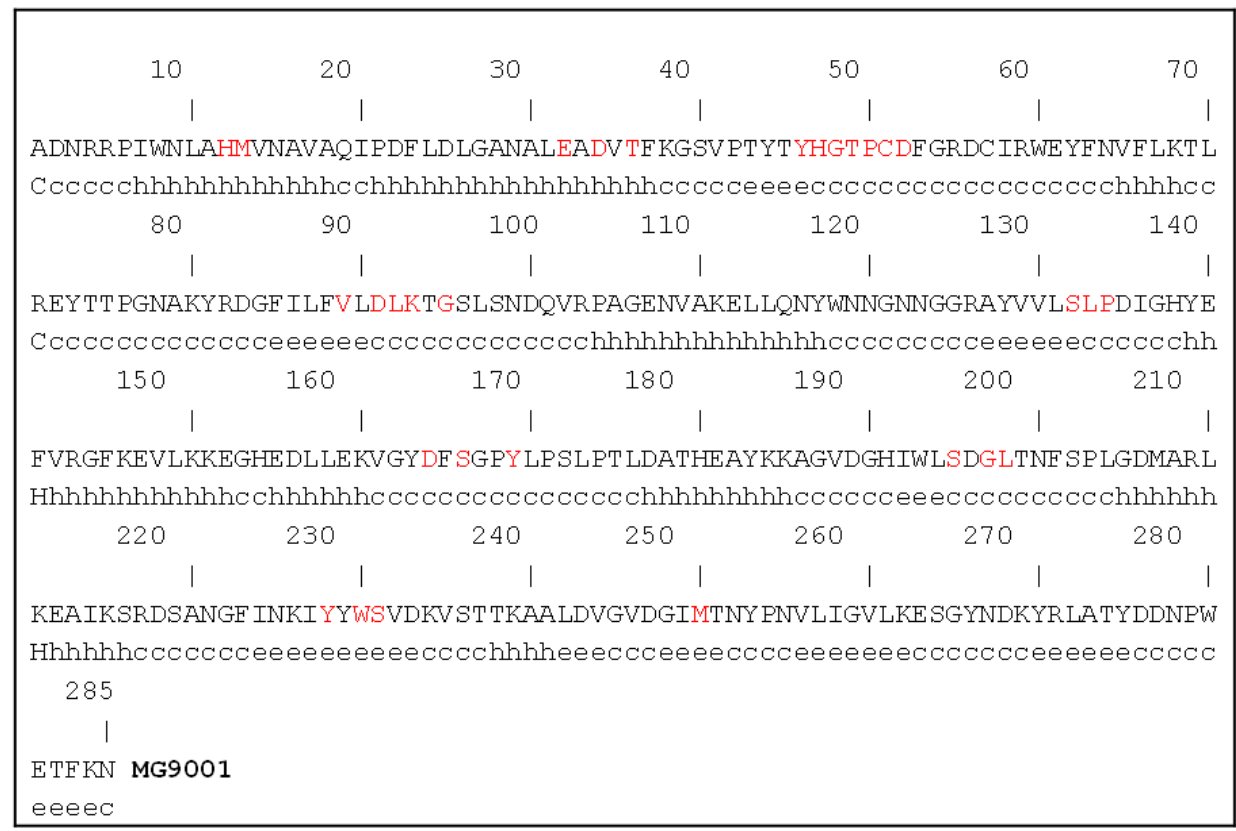

Resíduos de aminoácidos marcados em vermelho na estrutura secundária da SMase I (GOR4 - Secondary structure prediction- GARNIER et al., 1996) correspondem aos resíduos indicados ao software de docking como sítio de ancoragem para as moléculas ligantes. $\mathrm{O}$ íon $\mathrm{Mg}^{+2}$ numerado como o átomo 9001 da molécula, marcado em negrito, também faz parte do sítio de ancoragem para os ligantes.

A energia de Docking de cada ligante é dada de acordo com GoldScore, ChemScore e ASP (o potencial Astex Estatística). Estes scores dão pontuações de capacidade de ligação que são adimensionais, no entanto, em cada caso, a escala da pontuação fornece um guia de quão boa é a ancoragem do ligante à proteína, quanto maior a pontuação, provavelmente o resultado de encaixe será melhor.

As substâncias com maior energia de ligação, de acordo com o Goldscore (Tabela 2), foram então analisadas levando em consideração a regra de Lipinski, a qual se baseia na observação de que a maioria dos medicamentos são moléculas relativamente pequenas e lipofílicas (LIPINSKI et al., 2001; LIPINSKI, 2004). Tal regra é utilizada para avaliar o "druglikeness" de um ligante (conceito qualitativo utilizado no desenvolvimento de fármacos), ou seja, determinar se um composto químico, com certa atividade farmacológica ou biológica, tem propriedades que o tornem um fármaco possivelmente ativo pela via oral em humanos.

A regra é particularmente importante para o estudo de novos fármacos, processo no qual a estrutura de um ligante, farmacologicamente ativo, é otimizada, passo a passo, para obtenção de uma maior atividade e seletividade, bem como para assegurar se as propriedades 
físico-químicas dos ligantes candidatos foram mantidas. A modificação da estrutura molecular, muitas vezes leva a moléculas com peso molecular mais elevado, mais anéis, ligações mais rotativas, e uma maior lipofilicidade (LIPINSKI, 2004). Baseado em tais observações, a regra postula que no estudo de ligantes candidatos a fármacos não deve ser violado mais que um dos seguintes critérios: (1) possuir não mais que cinco ligações doadoras de hidrogênio (átomos de oxigênio ou nitrogênio com um ou mais átomos de hidrogênio - H Bond donors-Hbd); (2) possuir não mais que 10 ligações aceptoras de hidrogênio (átomos de oxigênio ou nitrogênio - $\mathrm{H}$ bond acceptors - Hba); (3) não exceder o peso molecular de 500 daltons; (4) O log do coeficiente de partição octanol-água $(P)$, que é uma estimativa da solubilidade, deve ser menor que cinco. Estas características estão diretamente relacionadas às propriedades farmacocinéticas das moléculas e outras como energia de dessolvatação polar e apolar, área total de superfície polar, carga e número de ligações rotativas que estão relacionadas ao aspecto farmacodinâmico das moléculas (MISHRA et al., 2009).

Com base nos scores gerados, foram selecionados 50 compostos, dos quais 14 puderam ser obtidos comercialmente (Aurora Fine Chemicals LLC, CA, EUA.), que foram numerados de 1 a 14 e, assim, identificados durante todo o desenvolvimento do presente projeto (Tabela 1; Figura 6). 
Tabela 1 - Compostos candidatos a inibidores de SMases D selecionados nos estudos de Docking molecular

\section{Molécula}

1 6-amino-2-((4-cyanobenzyl)thio)pyrimidina-4-yl 4-methylbenzenosulfonato

2

4-(\{[(4-chlorophenyl)sulfonyl $]$ oxy $\}$ imino $)-6-$ methylthiochromano

3

5-[(4-methoxyphenyl)sulfonylmethyl]-N-(2-pyridylmethyl)furan-2-carboxamida

4

N-[(1-phenylpyrazol-4-yl)methyl]-5-(phenylsulfonylmethyl)furan-2-carboxamida

5

4-bromo-N-[(E)-(2-methyl-1H-indol-3-yl)methyleneamino]benzenosulfonamida

6 4-methyl-3-oxo-2-(3-pyridylmethylene)benzo[3,4-b]furan-6-yl 4-chlorobenzenosulfonato

7 N-[[5-chloro-3-methyl-1-(p-tolyl)pyrazol-4-yl]methyleneamino]-4-ethoxy-benzenosulfonamida

8 ((1E)-2-indol-3-yl-1-azavinyl)[(4-methylphenyl)sulfonyl]amina)

9 methyl 6-\{[(4-methylphenyl)sulfonyl]oxy\}-4-(trifluoromethyl)thieno[2,3-b]pyridina-2-carboxylato

10 ((1E)-2-indol-3-yl-1-azavinyl)(phenylsulfonyl)amina

11 N'1-\{[2-(3-pyridyl)-1,3-thiazol-4-yl]carbonyl\}-2,4-difluorobenzeno-1-sulfonohydrazida

12 2-[(6-chloro-2-fluorophenyl)methylene]-3-oxobenzo[3,4-b]furan-6-yl benzenosulfonato

13 5-[4-(1,3-dithiolan-2-yl)phenoxy]sulfonylthiophene-3-carboxylico

14 N'-(2-chlorophenyl)sulfonyl-2-(3-pyridyl)thiazole-4-carbohydrazida

Compostos selecionados nos estudos de docking. Informaçãoes disponíveis no Zinc Database (Irwin et al., 2012 - www.zinc.docking.org). 
Figura 6 - Estrutura química dos compostos candidatos a inibidores de SMases D

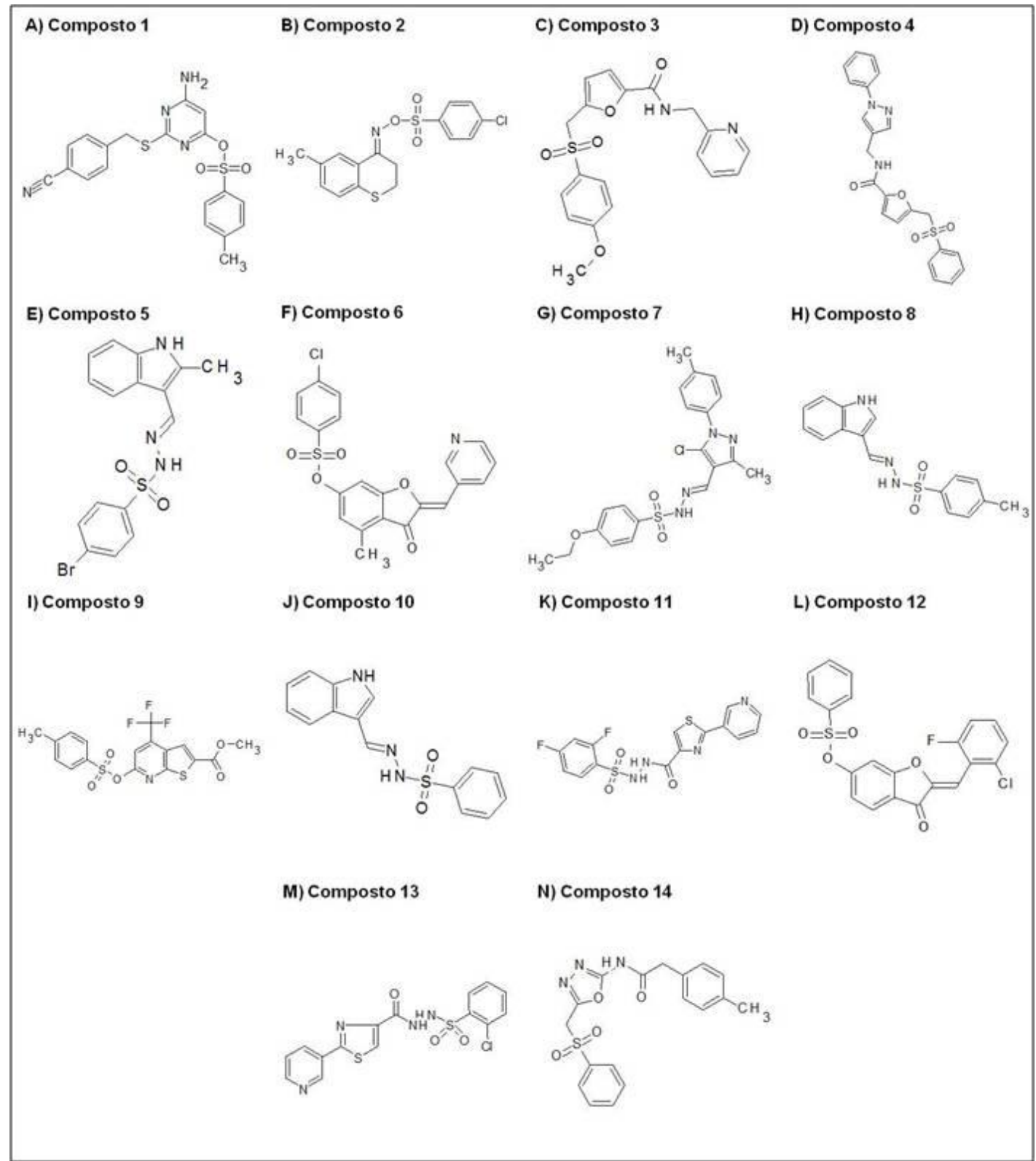

Os compostos numerados de 1 a 14 foram selecionados por Docking molecular e obtidos comercialmente junto à Aurora Fine Chemicals LLC.

Utilizando o próprio Zinc Database foi realizada uma busca pelas propriedades e informações disponíveis para cada um dos 14 ligantes selecionados. As propriedades descricionais importantes nas análises de Docking, bem como o valor do Goldscore de cada ligante e a participação em bioensaios estão apresentadas na Tabela 2. 
Tabela 2 - Propriedades físico-químicas e valores de Goldscore atribuídos para cada ligante.

\begin{tabular}{|c|c|c|c|c|c|c|c|c|c|c|c|c|c|c|}
\hline & \multicolumn{14}{|c|}{ COMPOSTOS } \\
\hline & 1 & 2 & 3 & 4 & 5 & 6 & 7 & 8 & 9 & 10 & 11 & 12 & 13 & 14 \\
\hline Peso molecular (g/mol) & 412,5 & 367,9 & 386,4 & 421,5 & 392,3 & 427,9 & 432,9 & 313,4 & 431,4 & 299,4 & 396,4 & 430,8 & 387,5 & 394,9 \\
\hline pH referência & 7 & 7 & 7 & 7 & 7 & 7 & 7 & 7 & 7 & 7 & 7 & 7 & 7 & 7 \\
\hline$x \log P^{\#}$ & 4,2 & 4,3 & 1,38 & 2,14 & 3,62 & 3,99 & 4,00 & 3,04 & 4,66 & 2,59 & 2,07 & 4,92 & 3,21 & 2,45 \\
\hline Dessolvatação apolar (kcal/mol) & 6,4 & $-3,1$ & 3,7 & $-3,1$ & $-5,7$ & $-2,42$ & 7,72 & 5,45 & $-2,46$ & $-5,06$ & 2,41 & $-1,29$ & 7,62 & $-8,77$ \\
\hline Dessolvatação polar (kcal/mol) & $-19,47$ & $-9,65$ & $-18,36$ & $-19,95$ & $-10,69$ & $-11,49$ & $-14,75$ & $-16,29$ & $-9,48$ & $-16,39$ & $-15,74$ & -13 & $-53,09$ & $-14,07$ \\
\hline Ligações doadoras de $\mathrm{H}$ & 2 & 0 & 1 & 1 & 2 & 0 & 1 & 2 & 0 & 2 & 2 & 0 & 0 & 2 \\
\hline Ligações aceptoras de $\mathbf{H}$ & 7 & 4 & 7 & 7 & 5 & 6 & 7 & 5 & 6 & 5 & 7 & 5 & 5 & 7 \\
\hline Área de superfície polar $\left(\AA^{2}\right)$ & 119 & 55 & 99 & 94 & 74 & 86 & 86 & 74 & 82 & 74 & 101 & 73 & 84 & 101 \\
\hline Ligações rotativas & 6 & 3 & 7 & 7 & 4 & 4 & 7 & 4 & 6 & 4 & 5 & 4 & 5 & 5 \\
\hline Carga & 0 & 0 & 0 & 0 & 0 & 0 & 0 & 0 & 0 & 0 & 0 & 0 & -1 & 0 \\
\hline Bioensaios disponíveis & Não & Não & Não & Não & Não & Não & Não & Não & Não & Não & Sim* & Não & Não & Não \\
\hline GOLDSCORE & 99,28 & 90,24 & 89,99 & 89,90 & 89,82 & 89,76 & 89,44 & 89,13 & 88,65 & 88,18 & 88,04 & 87,83 & 87,52 & 87,38 \\
\hline
\end{tabular}

Propriedades físico-químicas relevantes nos estudos de Docking. Informações disponíveis no Banco de dados Zinc Database (www.zinc.docking.org). Valores de Goldscore, representando a energia de ligação de cada molécula, gerados pelo sofware GOLD nos estudos de docking molecular. (*) Bioensaios disponíveis em http://pubchem.ncbi.nlm.nih.gov/assay/assay.cgi?cid=2824177. (\# xLogP - O log do coeficiente de partição octanol-água $(P)$, que é uma estimativa da solubilidade). 


\subsubsection{Solubilização dos inibidores}

Por se tratarem de compostos orgânicos, vários diluentes foram testados quanto à capacidade de solubilizar os possíveis candidatos a inibidores sem, contudo, interferir na atividade hidrolítica das SMases D, e que foram DMSO (DimetilSulfóxido - Merck, Darmstad, Alemanha), DMFA (DimetilFormamida - Merck), tampão PBS e água Milli Q estéril.

\subsubsection{Determinação da fluorescência basal dos inibidores}

Como o ensaio fluorimétrico para determinação da atividade esfingomielinásica foi a principal ferramenta para avaliação do possível efeito inibitório, cada um dos 14 compostos foi testado quanto à fluorescência basal. Para isso, amostras dos inibidores $(5-40 \mu \mathrm{l})$ foram incubadas com os substratos, ou seja, esfingomielina ou lisofosfatidilcolina (50 $\mu \mathrm{M})$ e as reações analisadas no espectrofluorímetro VICTOR, nos comprimentos de onda $\lambda 320$ e $\lambda 405$ nm. Nos ensaios onde veneno/toxina também foram incluídos, a fluorescência basal dos inibidores foi descontada, de acordo com o volume utilizado.

Outros compostos com conhecida ação sobre esfingomielinases celulares, como a Gentamicina e a Monensina (Sigma-Aldrich, MO, EUA), foram também testados quanto a capacidade de inibir as SMases D de Loxosceles. Estas substâncias foram diluídas em água Milli-Q ou etanol, conforme as especificações dos fabricantes, e também testadas quanto à fluorescência basal.

\subsection{Doses utilizadas e tratamento das amostras com os inibidores}

Segundo o Guidance for Industry S1C(R2): Dose Selection for Carcinogenicity Studies do FDA (Food and Drug Administration - USA, 2008) a determinação das doses a serem utilizadas em ensaios in vivo para testar a eficácia de novos fármacos, a carcinogenicidade, bem como, a toxicidade devem levar em consideração propriedades farmacológicas relevantes, como biodisponibilidade, farmacocinética, farmacodinâmica e toxicidade. No entanto, tais propriedades dos ligantes aqui estudados não são ainda completamente conhecidas. Ainda, de acordo com o Guidance $\mathrm{n}^{\circ} 129$ de 2010 da OECD (Organisation for economic co-operation and development) a mais alta concentração de 
substâncias preparadas em DMSO, a ser aplicada em testes, não deve ser superior a 2,5 $\mathrm{mg} / \mathrm{mL}$ e devem ser utilizadas concentrações ao redor do valor do $\mathrm{IC}_{50}$ de cada substância.

No presente estudo, as concentrações utilizadas nos ensaios in vitro estão abaixo dos valores de $\mathrm{IC}_{50}$, de cada molécula, e para os ensaios in vivo de uma a cinco vezes acima, sendo que, nenhuma das doses ultrapassou o limite de $2,5 \mathrm{mg} / \mathrm{mL}$.

Uma solução estoque, de maior concentração, para cada inibidor foi preparada em DMSO e as concentrações utilizadas nos ensaios foram alcançadas pela diluição da solução estoque em salina estéril $0,9 \%$. Como controle negativo das reações, foram utilizadas amostras de salina contendo a mesma quantidade de DMSO (Tabela 3).

Tabela 3 - Doses utilizadas e porcentagem de DMSO presente na solução dos inibidores em cada ensaio

\begin{tabular}{lcc}
\hline \multicolumn{1}{c}{ Ensaio } & Dose $(\boldsymbol{\mu M})$ & \% \\
& & \\
& 40 & 0,9 \\
Atividade Hidrolítica & 40 & 0,9 \\
Hemólise & 40 & 0,9 \\
Ligação da SMase ao eritrócito & 10 & 0,2 \\
Viabilidade celular & 10 & 0,2 \\
Dosagem de MMPs & 10 & 0,2 \\
Dosagem de citocinas & 40 & 0,9 \\
Ligação da SMase ao queratinócito & 40 & 0,9 \\
Sinalização via ERK & 40 & 0,9 \\
Análise de ROS & 40 & 0,9 \\
Análise de NO & 40 & 0,9 \\
Análise de Fas/FasL e TNF-R & $3 \mathrm{IC}_{50}$ & 0,09 \\
DL & 1,3 e $5 \mathrm{IC}_{50}$ & 0,4 \\
Dermonecrose & & \\
\end{tabular}

Concentrações crescentes dos compostos químicos foram incubadas, por 30 minutos à temperatura ambiente, com amostras do veneno de L. laeta $(10 \mu \mathrm{g})$ ou SMase I (5 $\mu \mathrm{g})$, e a atividade tóxica residual das amostras foi testada como descrito a seguir.

\subsection{Ação dos inibidores sobre a atividade hidrolítica das SMases D}

A atividade hidrolítica residual das amostras, após incubação do veneno/toxina com os inibidores sintéticos, foi determinada como descrito no item 3.5.1. Amostras contendo apenas 
o inibidor, tampão ou DMSO foram utilizadas como controles. Após a leitura, as porcentagens de inibição da hidrólise de SM ou LPC foram calculadas.

\subsubsection{Determinação dos valores de $I C_{50}$}

Os compostos $1,5,6,8,10,11$ e 12 foram testados em diferentes concentrações (10 a, no máximo, $200 \mu \mathrm{M}$ ) e a partir destas curvas foi calculado o $\mathrm{IC}_{50}$ (concentração inibitória $50 \%$ ) para cada inibidor. $\mathrm{O}$ valor de $\mathrm{IC}_{50}$ foi determinado pelo cálculo de regressão não linear das curvas obtidas em gráficos de porcentagem de inibição versus logaritmo da concentração molar dos compostos estudados. Os gráficos foram construídos com o programa GraphPad Prism, versão 5.00 para Windows, da GraphPad Software (San Diego, EUA).

\subsubsection{Análise do mecanismo de inibição}

Estes ensaios foram realizados com o auxílio da Dra. Fernanda C.V. Portaro, Laboratório de Imunoquímica, Instituto Butantan. Para tanto, foram realizados experimentos de fluorimetria, como descrito no item 3.5.1, utilizando quatro concentrações diferentes do substrato esfingomielina (SM), i.e., de 0,5 a 2 vezes o valor do Km (Michaelis-Mentem), determinado para a hidrólise de SM pela SMase I que é de 1,75 $\mu \mathrm{g}(2,3 \mu \mathrm{M})$. (SANTIFERRARA et al., 2009), ou seja, 1,15;2,3; 3,4 e 4,6 $\mu \mathrm{M}$. O tempo de reação foi de 15 minutos, a concentração da enzima fixada em $0,5 \mu \mathrm{g}$ e as moléculas inibidoras 1,5 e 6 foram testadas nas concentrações de 2,5 e $5 \mu \mathrm{M}$.

Para análise do mecanismo de inibição foram construídos plots de acordo com o método de Lineweaver-Burk, e os valores de $K_{i}$ calculados como descrito por Segel, (1975) a partir das seguintes equações:

$$
\begin{gathered}
\mathrm{Vo} / \mathrm{Vi}=1+[\mathrm{I}] / \mathrm{K}_{\mathrm{i} \text { aparente }} \\
\mathrm{K}_{\mathrm{i}}=\mathrm{Ki}_{\text {aparente }} /(1+[\mathrm{S}] / \mathrm{Km})
\end{gathered}
$$

Onde Vo = Velocidade inicial na ausência do inibidor; Vi= Velocidade na presença do inibidor; $[\mathbf{I}]=$ Concentração do inibidor; $\mathbf{K}_{\mathbf{i}}$ aparente $=$ Constante de inibição aparente; $\mathbf{K}_{\mathbf{i}}=$ Constante de inibição; [S]= Concentração de substrato; Km= Constante de Michaelis-Mentem que representa a concentração de substrato na qual a velocidade da reação atinge metade da velocidade máxima. 


\subsection{Análise da ação dos inibidores sobre o loxoscelismo sistêmico}

\subsubsection{Ação dos inibidores sobre o mecanismo de hemólise}

Amostras de veneno ou toxina recombinante, tratadas ou não com os inibidores, foram incubadas com eritrócitos humanos, os quais foram analisados por, citometria de fluxo, quanto a expressão de glicoforina $\mathrm{C}$ e ligação das SMases $\mathrm{D}$ às células. Para tanto, as amostras foram lavadas três vezes com $\mathrm{VBS}^{2+}$, ressuspendidas em tampão de FACS (PBS/BSA 0,1\%, azida sódica $0,01 \%$ ) e transferidas para microplacas com fundo em U (25 $\mu \mathrm{L} /$ poço). Estas foram incubadas com o anticorpo monoclonal anti-GPC (Bric 4 - BGRL, Reino Unido), ou com soro de coelho anti-SMases D de L. intermedia (TAMBOURGI et al., 1995), diluídos em tampão de FACS (1:250 e 1:100, respectivamente). Após incubação por 30 minutos e a $4{ }^{\circ} \mathrm{C}$, as hemácias foram lavadas três vezes, em tampão de FACS, e ressuspendidas no mesmo tampão. A seguir, alíquotas dos anticorpos secundários, anticamundongo ou anti-coelho, conjugados com FITC (isotiocianato de fluoresceína) (Pierce, IL, EUA) e diluídas 1:50 em tampão de FACS, foram adicionadas às células e as placas incubadas por 30 minutos a $4{ }^{\circ} \mathrm{C}$, no escuro. As células foram lavadas por três vezes, ressuspendidas em $250 \mu \mathrm{L}$ de tampão de FACS, contendo $1 \%$ de paraformaldeído, sendo a intensidade de fluorescência determinada em citômetro de fluxo (FACScalibur, Becton Dickinson, CA, EUA).

\subsubsection{Letalidade do veneno}

Grupos de quatro camundongos Balb/c foram inoculados pela via subcutânea com três diferentes concentrações do veneno de $L$. laeta $(2,5 ; 5$ e $10 \mu \mathrm{g} / 100 \mu \mathrm{L})$. A toxicidade foi acompanhada por um período de 72 horas e a $\mathrm{DL}_{50}$ calculada com o auxílio do programa Probit (FINNEY, 1971). Uma vez determinada a $\mathrm{DL}_{50}$, a toxicidade das amostras de veneno, preparadas na presença ou ausência dos inibidores, foi avaliada por meio da injeção de duas $\mathrm{DL}_{50}$ do veneno de L. laeta, pela via subcutânea, em grupos de quatro camundongos BALB/c. Neste ensaio os inibidores 1,5 e 6 foram testados em concentrações equivalentes a 3 IC $_{50}$ (145,95; 136,08 e 190,08 $\mu \mathrm{M}$, respectivamente). A proteção conferida pelos inibidores foi expressa em porcentagem de inibição da morte dos animais, calculada a partir do número de animais mortos no grupo injetado somente com veneno. 


\subsection{Análise da ação dos inibidores sobre o loxoscelismo cutâneo}

\subsubsection{Ação dos inibidores sobre a atividade das SMases D em queratinócitos humanos in vitro}

\subsubsection{Análise da viabilidade celular: ensaio com MTT}

Queratinócitos humanos $\left(1\right.$ x $10^{5}$ células/mL) da linhagem HaCat, foram cultivados em placas de 96 poços com meio DMEM completo e, posteriormente, mantidos por 24 horas em meio DMEM desprovido de SFB. Após este período, a ação dos inibidores na concentração de $10 \mu \mathrm{M}$, sobre a morte celular induzida por $5 \mu \mathrm{g}$ da toxina ou $10 \mu \mathrm{g}$ do veneno, foi avaliada pelo método do MTT (como descrito no item 3.6.2), após 72 horas de incubação.

\subsubsection{Tratamento das células para citometria de fluxo}

Culturas de queratinócitos humanos da linhagem HaCat foram tripsinizadas com ATV (Tripsina 0,2\% e Versene 0,02\%). As suspensões celulares foram lavadas $\left(1500 \mathrm{rpm}, 4{ }^{\circ} \mathrm{C}, 10\right.$ minutos) com meio DMEM completo, ressuspendidas em tampão $\mathrm{VBS}^{2+}$, sendo a concentração ajustada para $3 \times 10^{6}$ células $/ \mathrm{mL}$. Amostras das suspensões celulares $\left(1 \times 10^{6}\right.$ células/amostra) foram incubadas com veneno $(10 \mu \mathrm{g}) / \mathrm{SMase}$ I $(5 \mu \mathrm{g})$ na presença ou ausência dos inibidores $(10 \mu \mathrm{M})$, por 2 horas a $37^{\circ} \mathrm{C}$, sob agitação. Após o tratamento, as células foram centrifugadas três vezes em tampão $\mathrm{VBS}^{2+}$ a $1500 \mathrm{rpm}, 4{ }^{\circ} \mathrm{C}$ por $5 \mathrm{~min}$, sendo o sobrenadante coletado e estocado a $-20{ }^{\circ} \mathrm{C}$. Amostras tratadas apenas com tampão ou inibidor foram utilizadas como controles.

\subsubsection{Ligação das SMases D à superfície dos queratinócitos}

Queratinócitos ( 1 x $10^{6}$ células), tratados como acima descrito, foram transferidos para microplacas com fundo em U ( $25 \mu \mathrm{L} /$ poço). Estas foram incubadas com o soro anti-SMases D de Loxosceles produzido em cavalos, diluído em tampão de FACS 1:500. Após incubação por 30 minutos e a $4{ }^{\circ} \mathrm{C}$, as células foram lavadas três vezes, em tampão de FACS, e ressuspendidas no mesmo tampão. A seguir, alíquotas dos anticorpos secundários específicos, conjugados com FITC (Pierce, IL, EUA), diluídos 1:50 em tampão de FACS, foram adicionadas às células e as placas incubadas por 30 minutos a $4{ }^{\circ} \mathrm{C}$, no escuro. As células 
foram lavadas por três vezes, ressuspendidas em $250 \mu \mathrm{L}$ de tampão FACS, contendo $1 \%$ de paraformaldeído, sendo a intensidade de fluorescência determinada em citômetro de fluxo (FACScanto, Becton Dickinson, CA, EUA).

\subsubsection{Dosagem de MMPs no sobrenadante de cultura dos queratinócitos}

Sobrenadantes de culturas dos queratinócitos, tratadas por 72 horas com veneno, na presença ou ausência dos inibidores $(10 \mu \mathrm{M})$, foram centrifugados a $1500 \mathrm{rpm}$ por 10 min e testados por ensaios de ELISA, quanto à presença de MMP-2 e MMP-9, utilizando os Kits MMP-2 ELISA Kit (QIA63-1EA) e MMP-9 ELISA Kit (QIA56-1EA), conforme instruções do fabricante (Calbiochem ${ }^{\circledR}$, USA).

Em placas de 96 poços, já sensibilizadas com anticorpos monoclonais anti-MMP-2 ou anti-MMP-9, foram adicionados $50 \mu \mathrm{L} /$ poço do anticorpo detector (anticorpo monoclonal biotinilado anti-MMP-2 ou MMP-9) e, em seguida, $50 \mu \mathrm{L}$ das amostras e dos padrões recombinantes para a confecção da curva. As placas foram incubadas a $37{ }^{\circ} \mathrm{C}$ por 4 horas, para MMP-2, e a temperatura ambiente por 2 horas, para MMP-9. Na sequência, as placas foram lavadas por três vezes com tampão de lavagem fornecido no kit e, então, $100 \mu \mathrm{L} /$ poço do conjugado estreptoavidina-peroxidase diluído 1:400 (em diluente para o conjugado fornecido no kit), foram adicionados. As placas foram incubadas por $30 \mathrm{~min}$ a temperatura ambiente. Em seguida, foram novamente lavadas por três vezes e adicionados $100 \mu \mathrm{L} /$ poço do substrato TMB, sendo incubadas, a temperatura ambiente no escuro, por 30 min. A reação foi interrompida pela adição de $100 \mu \mathrm{l} /$ poço da solução Stop e a leitura realizada em leitor de placas (Multiskan-EX, Labsystems, Helsinki, Finlândia), nos comprimentos de onda de $\lambda 450$ e $540 \mathrm{~nm}$. O cálculo da concentração das MMPs nas amostras foi realizado com base nas curvas padrão de MMP-2 recombinante $(0,39$ a $50 \mathrm{ng} / \mathrm{mL})$ e MMP-9 recombinante $(0,078$ a $20 \mathrm{ng} / \mathrm{mL})$.

\subsubsection{Ação dos inibidores sobre a dermonecrose induzida pelo veneno de $\underline{\text { L. }} \underline{\text { laeta in vivo }}$}

Grupos de coelhos albinos adultos $(\mathrm{n}=12)$, pesando $3 \mathrm{~kg}$, foram inoculados pela via intradérmica, no dorso depilado, com $5 \mu \mathrm{g} / 200 \mu \mathrm{L}$ do veneno de L. laeta incubado com DMSO 1\% em salina ou com os inibidores 1, 5, 6, 8 e 10 nas concentrações equivalentes a 3 IC $_{50}(145,95 ; 136,08 ; 190,08 ; 220,8 ; 254,55 \mu \mathrm{M}$, respectivamente). Como controles, os animais receberam injeções de salina estéril, DMSO ou dos inibidores. As lesões 
dermonecróticas foram acompanhadas e medidas por até 72 horas e, após este período, os

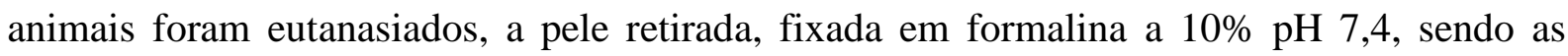
amostras encaminhadas para confecção de lâminas histológicas coradas com hematoxilinaeosina. Para os ensaios de dose resposta dos inibidores 5 e 6, os animais foram injetados com amostras de veneno incubadas com DMSO ou com os inibidores, nas concentrações equivalentes a 1,2 e 3 IC $_{50}(45,36 ; 90,72$ e 136,08 $\mu \mathrm{M}$ para o composto 5 e 63,36, 126,72 e 190,08 $\mu$ M para o composto 6) e as lesões acompanhadas e medidas por até 72 horas.

\subsubsection{Análise histopatológica das lesões dermonecróticas}

Fragmentos de pele das lesões dermonecróticas, induzidas por $5 \mu \mathrm{g}$ do veneno de $L$. laeta em coelhos na presença ou ausência dos inibidores, foram retirados e fixados em formol $4 \%$ pH 7,4. As amostras foram então encaminhadas para confecção de lâminas histológicas permanentes coradas com hematoxilina-eosina.

As lâminas foram analisadas e as fotomicrografias realizadas em Microscópio Leica DM2500 (Wetzlar, Alemanha) acoplado à Color Video Camera JVC com o auxílio do software Leica QWin Plus Y2.8 (Leica Microsystems Imaging solutions Ltd, Cambridge, UK).

\subsection{Novos estudos sobre o mecanismo de ação das SMases D de Loxosceles}

\subsubsection{Análise da participação da via de sinalização intracelular pERK 1/2 no mecanismo de ação das SMases D}

\subsubsection{Tratamento das células e preparo das amostras}

Culturas de queratinócitos humanos da linhagem HaCat foram tripsinizadas com ATV (Tripsina $0,2 \%$ e Versene $0,02 \%$ ). As suspensões celulares foram lavadas $\left(1500 \mathrm{rpm}, 4{ }^{\circ} \mathrm{C}, 10\right.$ minutos) com meio DMEM completo, ressuspendidas em meio desprovido de SFB, sendo a concentração ajustada para 1 x $10^{6}$ células $/ \mathrm{mL}$. Amostras das suspensões celulares foram incubadas com SMase I ( $5 \mu \mathrm{g})$, na presença ou ausência dos inibidores (40 $\mu \mathrm{M})$ ou meio, por 30 ou 60 min a $37^{\circ} \mathrm{C}$ em agitação. Após este período, as amostras foram centrifugadas (1500 rpm, 5 min a $4{ }^{\circ} \mathrm{C}$ ) e o sobrenadante foi descartado. As células foram, então, lavadas em PBS (1500 rpm, 5 min a $4{ }^{\circ} \mathrm{C}$ ), ressuspendidas em tampão de lise (Rippa Cell Lysis Buffer) 
suplementado com Coquetel Inibidor de Proteases $0,5 \mu \mathrm{L} / \mathrm{mL}$ (Sigma), PMSF $1 \mathrm{mM}$ (Boehringer Mannheim, IN, EUA), Ortovanadato de Sódio $2 \mathrm{mM}$ (Sigma) e Pirofosfato de Sódio $20 \mathrm{mM}$ (Sigma), homogeneizadas por agitação em vortex e incubadas por $5 \mathrm{~min}$ em gelo. A seguir, as amostras foram novamente homogeneizadas, centrifugadas (14000 rpm, 5 min a $4{ }^{\circ} \mathrm{C}$ ), os sobrenadantes aliquotados e estocados a $-80^{\circ} \mathrm{C}$.

\subsubsection{Ensaio para detecção de pERK 1/2}

Células HaCat tratadas com meio, veneno ou SMase I, na presença ou ausência de inibidores, foram analisadas quanto a ativação de pERK 1/2 utilizando-se o kit "Titerzime EIA Phospho-ERK1/2 Enzyme Immunometric Assay" (Assay Designs, EUA), de acordo com as recomendações do fabricante. Amostras da curva padrão e do extrato de células foram diluídas 1:4 em tampão de ensaio (Assay Buffer - Tampão tris-salina contendo proteínas, detergentes e inibidores de fosfatases) e $100 \mu \mathrm{L}$ destas foram adicionadas à placa de 96 poços, já sensibilizada com anticorpo monoclonal específico para ERK. A placa foi então incubada por uma hora a temperatura ambiente com agitação. Após a incubação, a placa foi lavada por três vezes com $400 \mu \mathrm{L} /$ poço de tampão de lavagem (Wash Buffer - Tampão tris-salina contendo detergentes), em seguida foram adicionados $100 \mu \mathrm{L}$ /poço de soro policlonal de coelho anti-pERK, exceto nas amostras relativas ao branco da reação, e a placa foi incubada por uma hora a temperatura ambiente com agitação. No passo seguinte, a placa foi novamente lavada por três vezes e foram, então, adicionados $100 \mu \mathrm{L}$ poço do conjugado específico (soro de cabra anti-IgG de coelho conjugado à peroxidase), exceto no branco, e a placa foi incubada por $30 \mathrm{~min}$ a temperatura ambiente com agitação. Após este período, a placa foi lavada como descrito anteriormente, foram adicionados $100 \mu \mathrm{L}$ /poço da solução substrato (3,3,'5,'5 tetrametilbenzidina [TMB] e peróxido de hidrogênio) e a placa foi incubada por $30 \mathrm{~min}$, a temperatura ambiente com agitação. Ao término da incubação, foram adicionados 100 $\mu \mathrm{L} /$ poço da solução Stop (Ácido clorídrico $1 \mathrm{~N}$ ) e a reação foi lida em leitor de placas (Multiskan-EX, Labsystems, Helsinki, Finlândia), no comprimento de onda de $\lambda 450 \mathrm{~nm}$. O cálculo da concentração de pERK nas amostras foi realizado com base na curva padrão de pERK recombinante $(62,5$ a $2.000 \mathrm{pg} / \mathrm{mL})$ com subtração do valor da D.O. do branco. As alíquotas testadas neste ensaio foram diluídas na mesma proporção, em tampão de lise, e a concentração de proteína das amostras foi determinada pelo método de Lowry et al. (1951), com base em uma curva de concentrações conhecidas de BSA $(25-2.000 \mu \mathrm{g})$, de modo a expressar os resultados em pg de pERK/mg de proteína total das amostras. 
3.13.2 Análise da produção de espécies reativas do oxigênio (ROS) e do nitrogênio (RNOS) por queratinócitos humanos tratados com a SMase I

A produção de ROS e RNOS por queratinócitos humanos tratados com a SMase I foi analisada por citometria de fluxo utilizando os reagentes Dihydroethidium - DHE (D7008, Sigma-Aldrich, MO, EUA) para detecção de superóxido $\left(\mathrm{O}_{2}{ }^{-}\right)$e Dihydrorhodamine 123 DHr (D1054, Sigma-Aldrich, MO, EUA) para a detecção de peroxinitrito (ONOO ${ }^{-}$).

Queratinócitos humanos foram tratados com a SMase I $(5 \mu \mathrm{g})$ como descrito no item 3.12.1.2 e alíquotas de $5 \times 10^{5}$ células $/ 50 \mu \mathrm{L}$ foram incubadas com $1 \mu \mathrm{L}$ dos reagentes DHE e $\operatorname{DHr}(5 \mu \mathrm{mol} / \mathrm{L})$, por 1 hora em estufa com atmosfera de $5 \%$ de $\mathrm{CO}_{2}$, à 37 e $30{ }^{\circ} \mathrm{C}$, respectivamente. Passado o período de incubação, as células foram centrifugadas a $1500 \mathrm{rpm}$ por 5 minutos, o sobrenadante foi desprezado e as células ressuspendidas em $300 \mu \mathrm{L}$ de tampão FACS contendo paraformaldeído 1\%. A intensidade de fluorescência foi determinada em citômetro de fluxo (FACScanto, Becton Dickinson, CA, EUA).

A produção de óxido nítrico foi quantificada pela determinação das concentrações de nitrito, um dos produtos finais do NO, no sobrenadante da cultura de queratinócitos humanos tratados com $5 \mu \mathrm{g}$ de SMase I por 2 horas. Em placas de 96 poços de fundo chato, foram adicionadas alíquotas de $50 \mu \mathrm{L}$ das amostras e $50 \mu \mathrm{L}$ das diluições da curva padrão. Em seguida foram acrescentados a cada poço, $50 \mu \mathrm{L}$ do reagente de Griess (1\% sulfanilamida em $2.5 \% \mathrm{H}_{3} \mathrm{PO}_{4}, 1 \% \mathrm{~N}-1$ Naphtyl-ethilenodiamine em $2.5 \% \mathrm{H}_{3} \mathrm{PO}_{4)}$ e a reação foi lida em leitor de placas (Multiskan-EX, Labsystems, Helsinki, Finlândia), no comprimento de onda de $\lambda$ $540 \mathrm{~nm}$. A concentração de NO foi calculada com base na curva padrão de nitrito de sódio $\left(\mathrm{NaNO}_{2}\right)$ de 500 a $10.000 \mathrm{nM}$, de acordo com os procedimentos descritos por Ding et al. (1988).

\subsubsection{Investigação do mecanismo de apoptose induzido pelas SMases D em queratinócitos humanos}

\subsubsection{Análise da expressão de Fas (CD95) e FasL (CD178)}

Queratinócitos (5 x $10^{5}$ células) tratados, como descrito no item 3.11.1.2, foram transferidos para microplacas com fundo em U ( $25 \mu \mathrm{L} /$ poço). Estas foram incubadas com os anticorpos monoclonais dirigidos contra CD95/FITC e CD178/biotina obtidos da BD (Becton Dickinson, CA, EUA), e diluídos em tampão de FACS para 1:100. Após incubação por 30 
minutos e a $4{ }^{\circ} \mathrm{C}$, as células incubadas com anti-CD95 foram lavadas três vezes e ressuspendidas em $250 \mu \mathrm{L}$ de tampão FACS, contendo $1 \%$ de paraformaldeído. As células incubadas com anti-CD178 foram lavadas três vezes e a elas adicionadas alíquotas da estreptoavidina-FITC, na diluição 1:100 em tampão de FACS. A seguir, as células foram incubadas por 30 minutos a $4{ }^{\circ} \mathrm{C}$, no escuro. Após a incubação, as células foram lavadas por três vezes, ressuspendidas em $250 \mu \mathrm{L}$ de tampão FACS, contendo $1 \%$ de paraformaldeído, sendo a intensidade de fluorescência determinada em citômetro de fluxo (FACScanto, Becton Dickinson, CA, EUA).

\subsubsection{Análise da expressão dos receptores de TNF (CD120a e CD120b)}

Queratinócitos (5 x $10^{5}$ células) tratados, como descrito no item 3.11.1.2, foram transferidos para microplacas com fundo em U ( $25 \mu \mathrm{L} /$ poço). Estas foram incubadas com os anticorpos monoclonais dirigidos contra TNF-RI (Purified mouse anti-human CD120a) e TNF-RII (Purified rat anti-human CD120b) obtidos da BD (Becton Dickinson, CA, EUA), e diluídos em tampão de FACS para 1:50. Após incubação por 30 minutos a $4^{\circ} \mathrm{C}$, as células foram lavadas três vezes e incubadas com os anticorpos secundários específicos marcados com biotina, na diluição de 1:50, e a reação procedeu por mais 30 min a $4{ }^{\circ} \mathrm{C}$. Passado este período, as células foram novamente lavadas por três vezes e incubadas com EstreptoavidinaPE na diluição de 1:200 por 30 min à $4{ }^{\circ} \mathrm{C}$ no escuro. Em seguida, foram realizadas novas lavagens e ao final, as células foram ressuspendidas em $300 \mu \mathrm{L}$ de tampão FACS contendo paraformaldeído $1 \%$. A intensidade de fluorescência foi então determinada em citômetro de fluxo (FACScanto, Becton Dickinson, CA, EUA).

\subsubsection{Dosagem de citocinas no sobrenadante de cultura de queratinócitos humanos tratados com a SMase I}

Para as reações de ELISA, foram utilizados Kits BD OptEIA ${ }^{\mathrm{TM}}$ Set Human IL-1 $\beta$, TNF- $\alpha$, IL-6, IL-10 e TGF- $\beta 1$ de acordo com as instruções do fabricante. As placas foram sensibilizadas com $50 \mu \mathrm{L}$ /poço dos anticorpos de captura na diluição de 1:250 em tampão carbonato de sódio 0,1 M, pH 9,5 (7,13 $\mathrm{g} \mathrm{NaHCO}_{3}, 1,59 \mathrm{~g} \mathrm{Na}_{2} \mathrm{CO}_{3}$; quantidade para um litro) e incubadas overnight a $4{ }^{\circ} \mathrm{C}$. Após a incubação, as placas foram lavadas três vezes com PBS contendo $0,05 \%$ de Tween-20, as ligações inespecíficas bloqueadas com $200 \mu \mathrm{L} /$ poço de PBS contendo $10 \%$ de SFB e, em seguida, incubadas por uma hora a temperatura ambiente. As 
placas foram lavadas por três vezes, $50 \mu \mathrm{L}$ /poço de cada amostra experimental e dos padrões da curva, diluídos em tampão de ensaio, foram adicionados e as placas incubadas por duas horas a temperatura ambiente. Na etapa seguinte, as placas foram lavadas cinco vezes e 50 $\mu \mathrm{L} /$ poço de uma solução contendo o anticorpo de detecção, nas diluições de 1:1000, 1:500, 1:250, 1:500 e 1:250 para IL-1 $\beta$, TNF- $\alpha$, IL-6, IL-10 e TGF- $\beta 1$ respectivamente, e o reagente enzimático (estreptoavidina conjugada a peroxidase 1:250) diluídos em tampão de ensaio foram adicionados. As placas foram incubadas por uma hora para TNF- $\alpha$, IL-6, IL-10 e TGF$\beta 1$ e 90 minutos para a IL-1 $\beta$, à temperatura ambiente. Passado o período de incubação, cada placa foi lavada por sete vezes e $50 \mu \mathrm{L}$ poço do substrato TMB foi acrescentado. As placas foram incubadas por 30 min à temperatura ambiente ao abrigo da luz, e a reação foi interrompida pela adição de $50 \mu \mathrm{L}$ poço da solução de Stop $\left(\mathrm{H}_{2} \mathrm{SO}_{4} 2 \mathrm{~N}\right)$ e lida em leitor de placas (Multiskan-EX, Labsystems, Helsinki, Finlândia), no comprimento de onda de $\lambda 450$ nm. O cálculo da concentração das citocinas nas amostras foi realizado com base nas curvas padrão de IL-1 $\beta$ recombinante $(3,9$ a $250 \mathrm{pg} / \mathrm{mL})$, TNF- $\alpha$ recombinante $(7,8$ a $500 \mathrm{pg} / \mathrm{mL})$, IL-6 recombinante $(4,7$ a 300 pg/mL), IL-10 recombinante (7,8 a 500 pg/mL), TGF- $\beta 1$ recombinante (125 a 8.000 pg/mL) e com subtração do valor da D.O. do branco.

\subsection{Análise estatística}

Os dados foram expressos como média \pm erro padrão e analisados estatisticamente com o auxílio do programa GraphPad Prism, versão 5.1 para Windows, da GraphPad Software (San Diego, EUA).

As comparações entre mais de dois grupos em relação a uma variável foram realizadas pelo teste One Way ANOVA e as comparações múltiplas realizadas pelo post-hoc de Tukey HSD. Para comparações de duas ou mais variáveis, entre mais de dois grupos, foi utilizado o teste Two Way ANOVA, seguido por post-hoc de Bonferroni. O teste $t$ de Student foi utilizado para comparações entre dois grupos. As correlações estatísticas foram realizadas por meio do teste de Correlação de Pearson e para todos os testes os valores de $\mathrm{p}<0,05$ foram considerados significativos. 


\section{RESULTADOS}

\subsection{Análise da presença de endotoxina nas amostras de veneno e toxina recombinante}

A avaliação das amostras de veneno e SMase I recombinante, pelo método de LAL para a detecção de endotoxina, demonstrou que ambas amostras apresentaram níveis de endotoxina inferiores aos limites de detecção do método, ou seja, $<0,125 \mathrm{EU} / \mathrm{mL}$.

\subsection{Expressão e purificação da SMase I recombinante}

Células competentes de E. coli (BL21 DE3) foram transformadas com o vetor de expressão pAE contendo o gene de interesse, ou seja, SMase I de L. laeta (FERNANDESPEDROSA et al., 2002). A análise dos extratos bacterianos por SDS-PAGE mostrou a presença de várias bandas incluindo as com $\mathrm{Mr} \sim 35 \mathrm{kDa}$, correspondentes a proteína recombinante, cuja intensidade foi amplificada após adição de IPTG e glicose (dados não mostrados).

A proteína recombinante foi purificada da fração solúvel dos extratos bacterianos por cromatografia de afinidade e eluída em tampão Fosfato de Sódio pH 6,0 (tampão wash) contendo 0,8 M de Imidazol. As amostras obtidas foram submetidas a eletroforese em SDSPAGE em condições redutoras, sendo o gel corado por impregnação com nitrato de prata. A Figura 7 mostra que a proteína recombinante foi eluída com alto grau de pureza, como observado pela presença de uma única banda com Mr em torno de $35 \mathrm{kDa}$. 
Figura 7 - Análise eletroforética das amostras obtidas durante o processo de purificação da SMase I por cromatografia de afinidade

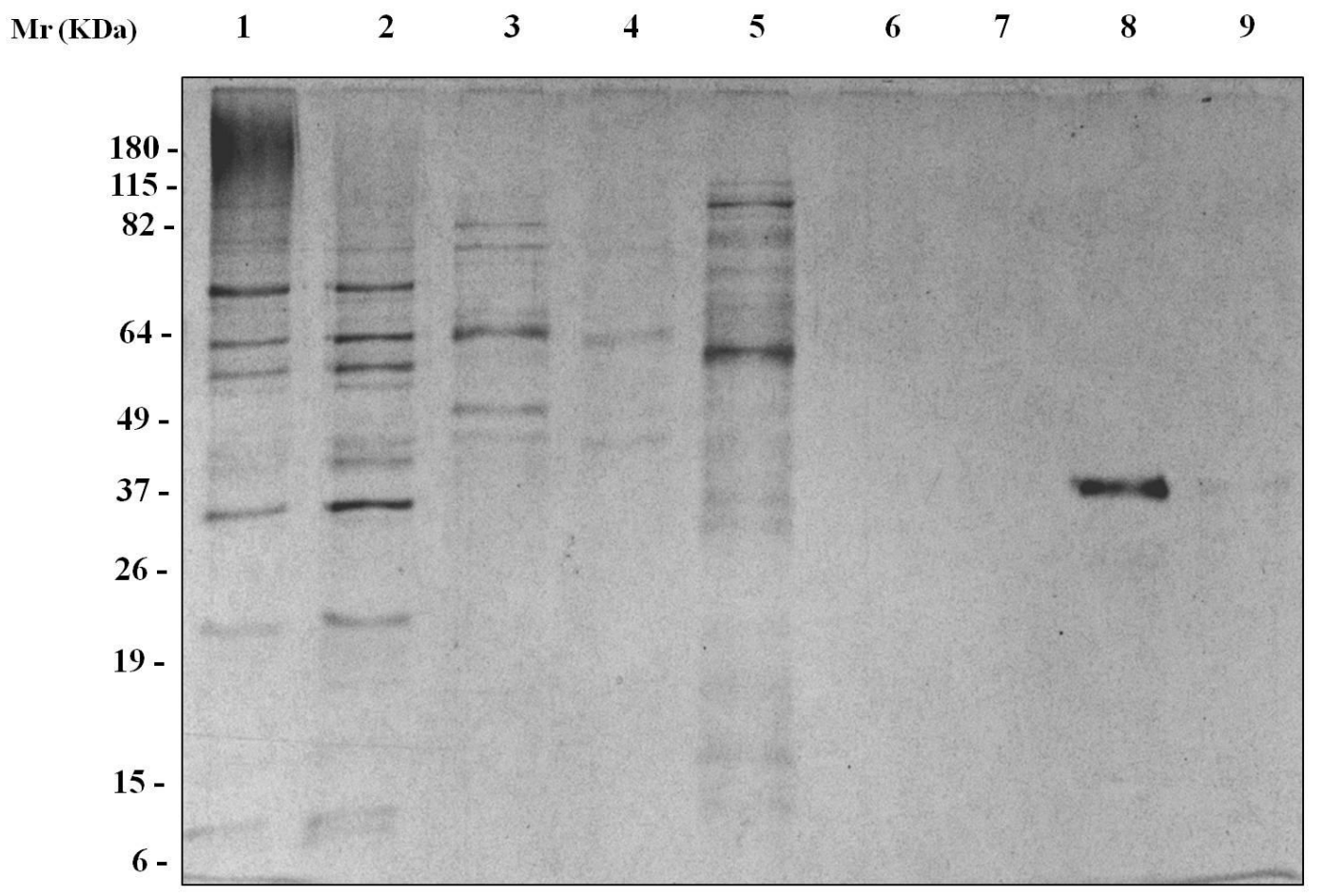

Amostras coletadas durante o processo de purificação foram reduzidas com tampão de amostra contendo 2mercaptoetanol, aquecidas a $96{ }^{\circ} \mathrm{C}$ por 10 minutos e submetidas à eletroforese em gel de poliacrilamida a $12 \%$. 1) Eluato; 2 e 3) Tampão binding ( $\mathrm{pH} 7,8) ; 4$ e 5) Tampão wash (pH 6,0); 6 e 7) Tampão wash contendo 60 mM de Imidazol; 8 e 9) Tampão wash contendo $0,8 \mathrm{M}$ de imidazol. A corrida procedeu em voltagem constante a 100 volts e as bandas foram reveladas por impregnação com nitrato de prata. 


\subsection{Perfil eletroforético do veneno e da toxina recombinante}

A análise eletroforética do veneno de $L$. laeta revelou a presença de vários componentes com massa molecular entre 6 e $200 \mathrm{kDa}$. A análise revela ainda o alto grau de pureza da toxina recombinante após a cromatografia de afinidade e concentração da amostra em Centricon com cutoff de $30 \mathrm{kDa}$ (Figura 8).

Figura 8 - Análise eletroforética do veneno de L. laeta e da SMase I recombinante após a etapa de concentração

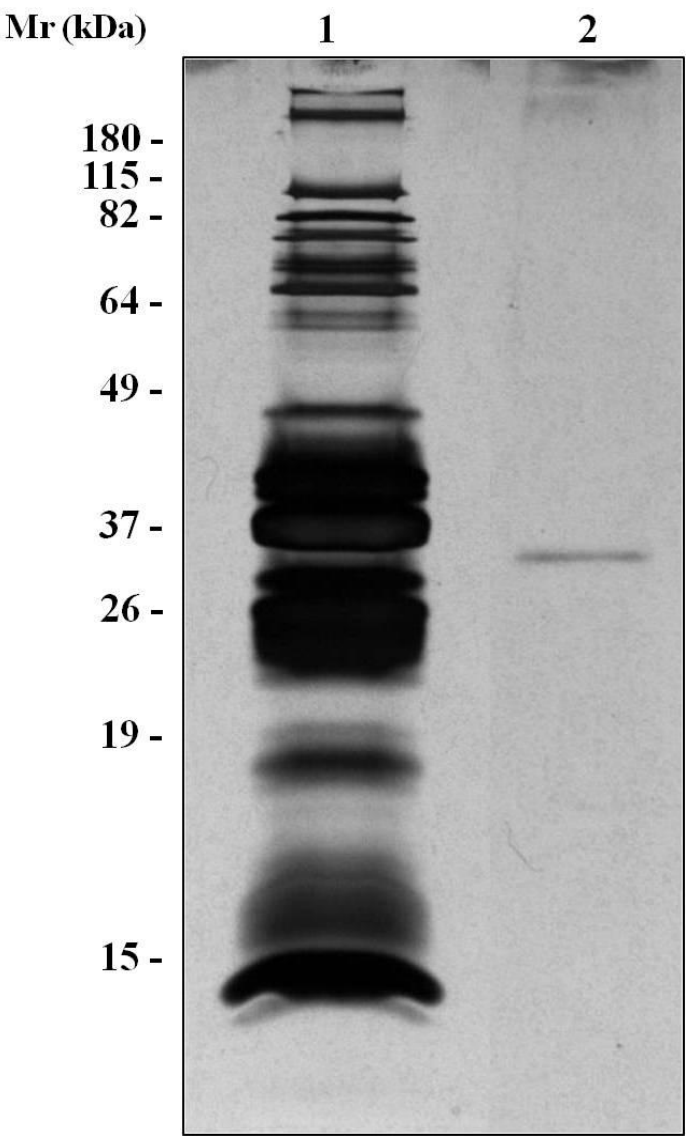

As amostras foram solubilizadas em condições não redutoras e submetidas à eletroforese em gel de poliacrilamida a $12 \%$. 1) Veneno $(10 \mu \mathrm{g}) ; 2)$ SMase I recombinante $(1 \mu \mathrm{g})$. A corrida procedeu em voltagem constante de 100 volts e as bandas foram reveladas por impregnação com nitrato de prata. 


\subsection{Caracterização das atividades do veneno e da toxina recombinante}

\subsubsection{Atividade hidrolitica}

A Figura 9 mostra que tanto o veneno de L. laeta como a toxina recombinante foram capazes de hidrolisar esfingomielina e lisofosfatidilcolina embora com eficiências distintas, sendo a SMase D mais ativa na clivagem de ambos os substratos.

Figura 9 - Hidrólise da esfingomielina e lisofosfatidilcolina

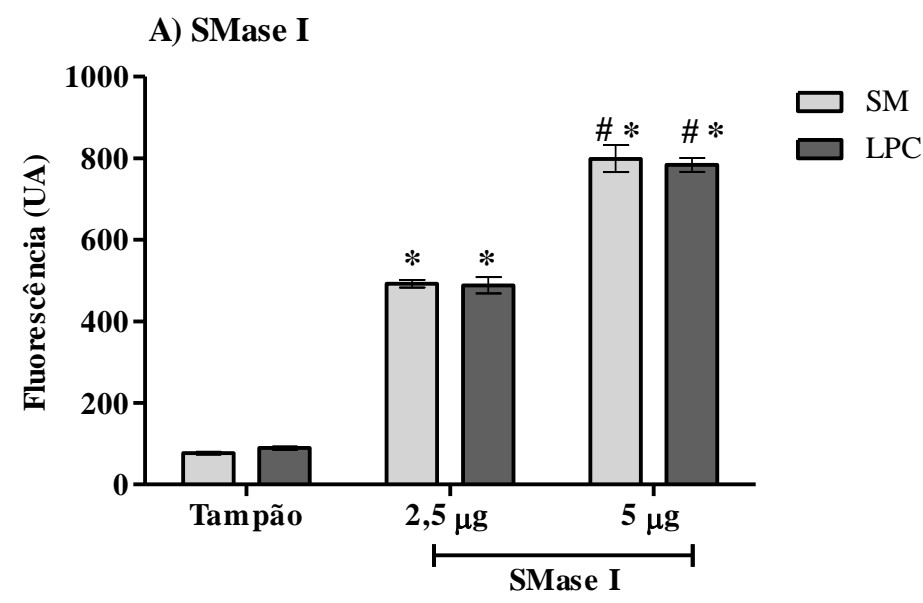

B) Veneno

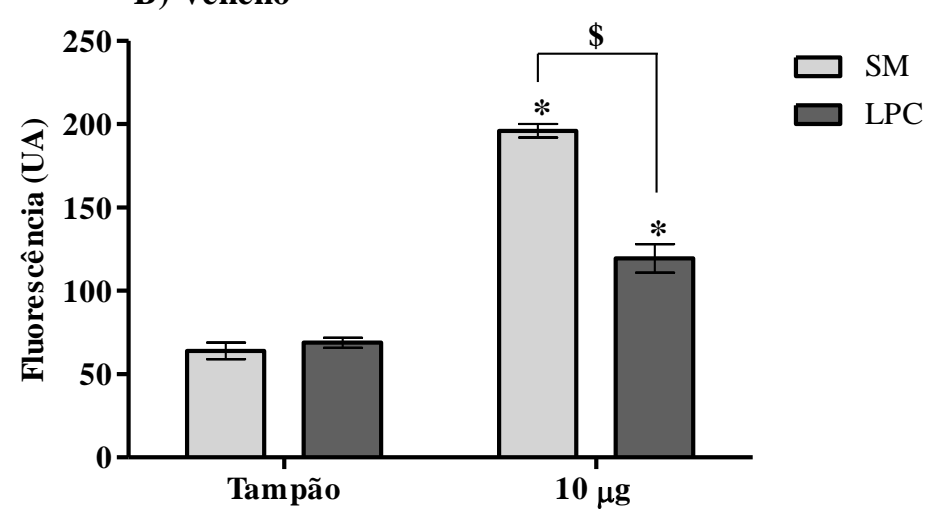

Amostras de esfingomielina (SM) e lisofosfatidilcolina (LPC) $(50 \mu \mathrm{M})$ foram incubadas por 30 min a $37{ }^{\circ} \mathrm{C} \mathrm{com}$ 2,5 e $5 \mu \mathrm{g}$ de SMase I, ou $10 \mu \mathrm{g}$ do veneno de L. laeta. A liberação de colina, com consequente oxidação à betaína e $\mathrm{H}_{2} \mathrm{O}_{2}$, foi determinada em fluorímetro e a hidrólise expressa em unidades arbitrárias de fluorescência. A) Hidrólise da SM e LPC pela SMase D; B) Hidrólise da SM e LPC pelo veneno de L. laeta. Os dados estão representados como média \pm erro padrão de duplicatas representativo de dois experimentos independentes. Analisado estatisticamente por Two-Way Anova seguido por teste de Tukey HSD. (*) Diferença significativa em relação ao tampão $(p<0,05)$; (\#) Diferença significativa em relação à concentração de $2,5 \mu \mathrm{g}$ para SMase $\mathrm{D}$ $(p<0,05)$; $(\$)$ diferença em relação à clivagem do LPC para o veneno $(p<0,05)$. 


\subsubsection{Ação sobre queratinócitos humanos: viabilidade celular}

A incubação dos queratinócitos humanos, com $5 \mu \mathrm{g}$ da SMase I por 24 horas, induziu perda de aproximadamente $45 \%$ da viabilidade celular, sendo que neste mesmo período, 10 $\mu \mathrm{g}$ do veneno de L. laeta não foi capaz de induzir morte celular significativa. Após 48 e 72 horas de incubação, tanto o veneno quanto a SMase I foram capazes de causar uma redução significativa da viabilidade celular (Figura 10).

Figura 10 - Viabilidade de células HaCat tratadas com veneno ou toxina recombinante de $L$. laeta

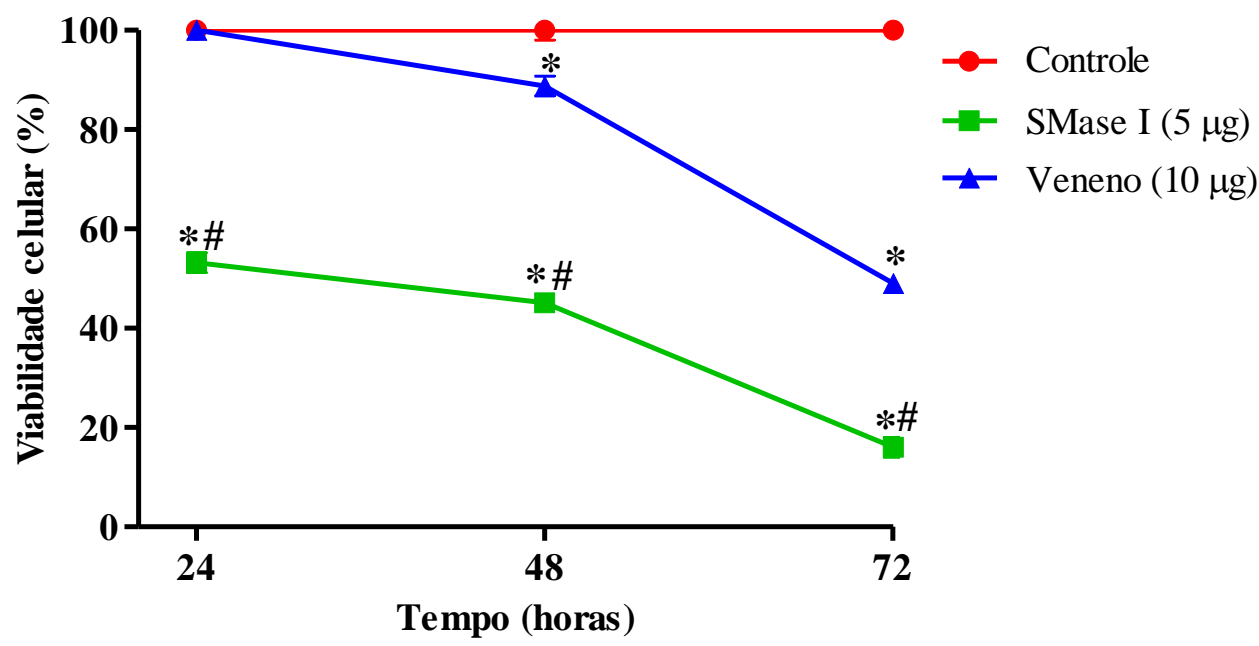

Células HaCat $\left(5 \times 10^{4}\right)$ foram tratadas com $10 \mu \mathrm{g}$ de veneno ou $5 \mu \mathrm{g}$ de SMase I. Como controle, foram analisadas células tratadas apenas com meio de cultura. A viabilidade celular foi avaliada após 24,48 e 72 h dos tratamentos, pelo método de MTT, e expressa em porcentagem. Os dados estão representados como média \pm erro padrão de duplicatas representativo de três experimentos independentes. Analisado estatisticamente por TwoWay ANOVA seguido por teste de Tukey HSD. (*) Diferença significativa em relação ao controle nos respectivos tempos $(p<0,05)$; (\#) Diferença significativa entre SMase I e Veneno nos respectivos tempos $(p<0,05)$. 


\subsubsection{Atividade hemolítica}

A incubação de eritrócitos humanos, previamente tratados com $5 \mu \mathrm{g}$ de veneno, com soro normal humano, resultou em 100\% de hemólise (Figura 11B). O tratamento dos eritrócitos com $1 \mu \mathrm{g}$ de SMase I e posterior incubação com soro humano normal induziu aproximadamente $75 \%$ de lise, sendo que, em concentrações maiores $(2,5 \mu \mathrm{g}$ e $5 \mu \mathrm{g})$ resultaram em 100\% de hemólise (Figura 11A).

Figura 11 - Hemólise dependente do sistema complemento

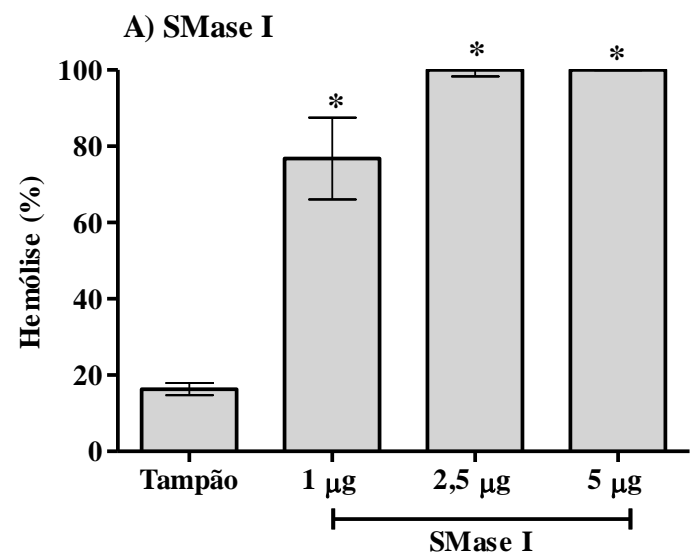

B) Veneno

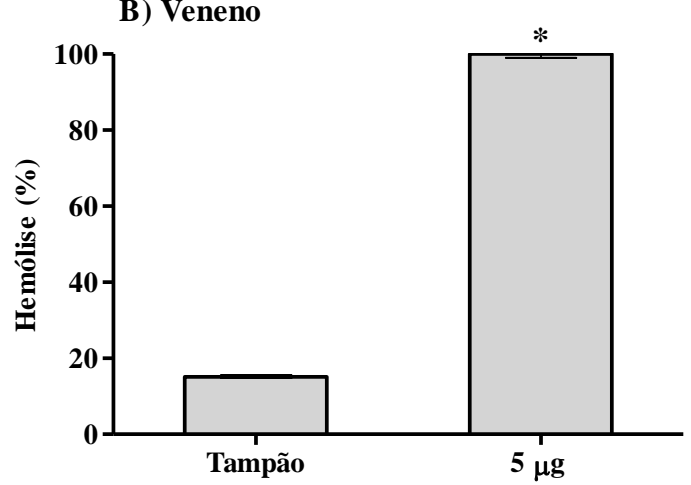

Amostras de eritrócitos ( $1 \mathrm{~mL}$ ) foram incubados com 1, 2,5 e $5 \mu \mathrm{g}$ de SMase I ou $5 \mu \mathrm{g}$ do veneno de $L$. laeta por $30 \mathrm{~min}$ a $37^{\circ} \mathrm{C}$, respectivamente. Posteriormente, $100 \mu \mathrm{l}$ das células tratadas foram incubados com soro humano normal $(1: 2)$ por $1 \mathrm{~h}$ a $37^{\circ} \mathrm{C}$. Após a incubação, as células foram centrifugadas e o sobrenadante foi submetido à leitura em espectrofotômetro a $414 \mathrm{~nm}$. A atividade hemolítica foi expressa pela porcentagem de lise. Os dados estão representados como média \pm erro padrão de duplicatas representativo de dois experimentos independentes. Analisado estatisticamente por teste t de Student para o ensaio com veneno e One-Way ANOVA seguido por teste de Tukey HSD para o ensaio com a toxina. (*) Diferença significativa em relação ao tampão $(p<0,05)$. 


\subsection{Características dos compostos inibidores}

Os candidatos a inibidores de SMases D, por serem compostos orgânicos, foram diluídos em DMSO. A escolha de tal diluente foi baseada em experimentos nos quais foi analisada a interferência de diluentes como DMSO, DMFA, água Milli-Q e tampão PBS sobre a atividade hidrolítica do veneno/SMase D. A figura 10A mostra que água Milli Q, DMSO e tampão PBS não interferiram de maneira significativa na atividade esfingomielinásica, no entanto, o DMFA causou aumento nos valores basais de hidrólise do substrato. Por outro lado, nem água ou tampão PBS foram capazes de solubilizar adequadamente os compostos (Figura 12A).

Nos ensaios in vivo, o diluente DMSO apresentou propriedades capazes de interferir no desenvolvimento da lesão dermonecrótica em coelhos e com a dose letal em camundongos, portanto, nestes experimentos, uma solução estoque foi preparada em DMSO e diluída em salina estéril para as concentrações a serem utilizadas.

A fluorescência basal dos compostos variou de acordo com volume/concentração utilizados e, por isso, tal valor foi descontado nos ensaios de fluorimetria. O composto de número 09 apresentou uma fluorescência basal extremamente alta e, por isso, não foi possível testar sua capacidade inibitória (Dados não mostrados).

Para a Gentamicina e Monensina, os diluentes recomendados pelos fabricantes, água e etanol, respectivamente, não interferiram na atividade da enzima, sendo que a fluorescência basal dos diluentes e dos compostos foi baixa e semelhante ao controle negativo (Figura 12B). No entanto, os valores basais de fluorescência foram também descontados nos ensaios de inibição da atividade hidrolítica. 
Figura 12 - Análise da interferência dos diluentes dos compostos inibidores na atividade esfingomielinásica

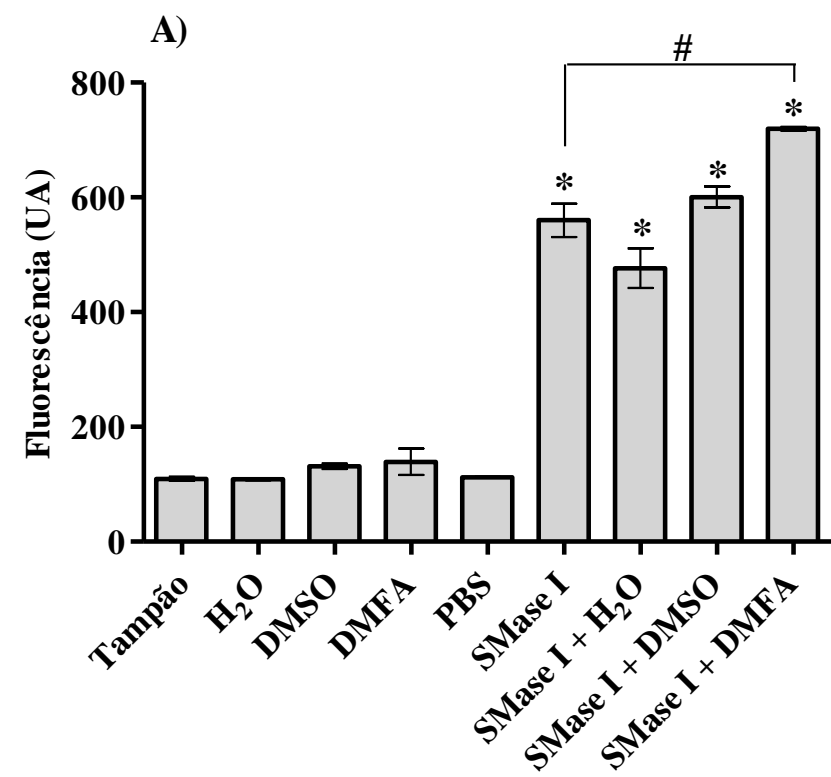

B)

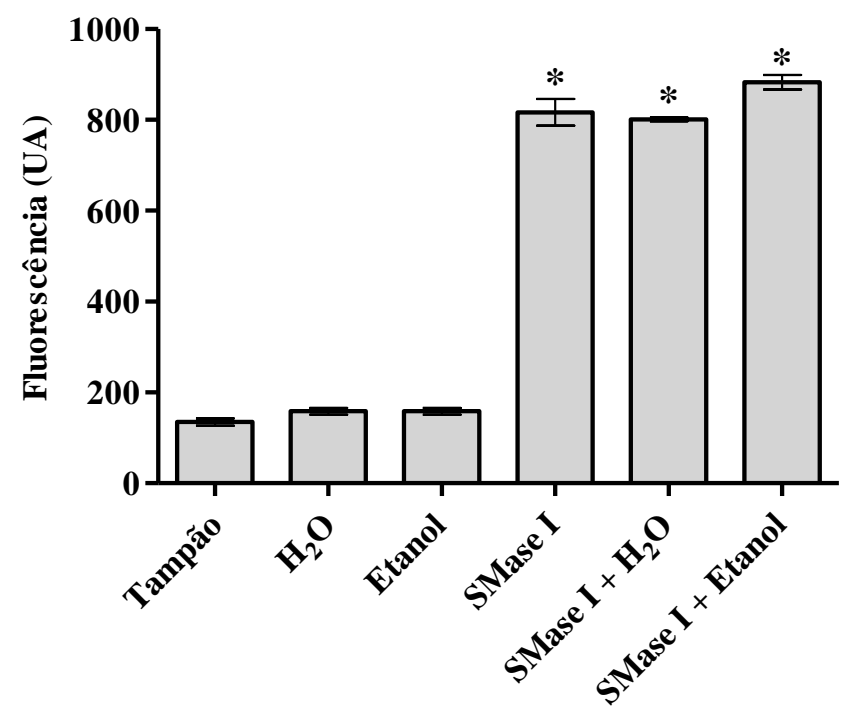

Amostras de esfingomielina $(50 \mu \mathrm{M})$ foram incubadas por 30 min a $37^{\circ} \mathrm{C}$ com $10 \mu \mathrm{l}$ de cada diluente ou $5 \mu \mathrm{g}$ de SMase I, tratada ou não com $10 \mu \mathrm{L}$ de cada diluente. A liberação de colina, com consequente oxidação à betaína e $\mathrm{H}_{2} \mathrm{O}_{2}$, foi determinada em fluorímetro e a hidrólise expressa em unidades arbitrárias de fluorescência. A) Diluentes utilizados no preparo dos compostos inibidores desenhados nos estudos de Docking; B) Diluentes utilizados no preparo dos inibidores de SMases celulares. Os dados estão representados como média \pm erro padrão de duplicatas representativo de dois experimentos independentes. Analisado estatisticamente por OneWay Anova seguido por teste de Tukey HSD. (*) Diferença significativa em relação ao tampão $(p<0,05)$; (\#) Diferença significativa em relação à SMase $\mathrm{D}(p<0,05)$. 


\subsection{Análise da ação dos compostos selecionados nos estudos de Docking sobre a atividade hidrolítica}

\subsubsection{Atividade hidrolítica sobre o substrato esfingomielina (SM)}

A capacidade inibitória dos compostos foi testada inicialmente utilizando $40 \mu \mathrm{M}$ de cada inibidor, $5 \mu \mathrm{g}$ de SMase I ou $10 \mu \mathrm{g}$ do veneno de L. laeta. A Figura 13A mostra que todos os compostos foram capazes de interferir com a atividade da toxina recombinante, sendo o de número 10 o mais eficiente, inibindo em $56,7 \%$ da atividade. Os compostos que induziram mais de $20 \%$ de inibição foram selecionados para as análises subsequentes.

A Figura 13B mostra que dos compostos testados, somente os inibidores 1, 5, 6, 8 e 12 foram capazes de reduzir, significativamente, a atividade esfingomielinásica do veneno de $L$. laeta, sendo o de número 5, o mais eficiente, promovendo 52,9\% de inibição.

\subsubsection{Determinação dos valores de $\mathrm{IC}_{50}$}

Os compostos, assim selecionados, foram testados em diferentes concentrações (10 a, no máximo, $200 \mu \mathrm{M}$ ). A Figura 14 mostra que, com exceção dos compostos $n^{\circ} 7$ e 12 a inibição da atividade esfingomielinásica ocorreu de forma dose dependente.

A partir destas curvas foi calculado o $\mathrm{IC}_{50}$ (concentração inibitória 50\%) para cada inibidor (Tabela 4, Figura 15). O valor de $\mathrm{IC}_{50}$ foi determinado pelo cálculo de regressão nãolinear das curvas obtidas em gráficos de porcentagem de inibição versus logaritmo da concentração molar dos compostos estudados (Figura 14). Para os inibidores 7, 11 e 12 não foi possível calcular o $\mathrm{IC}_{50}$, uma vez que estes compostos não foram capazes de produzir $50 \%$ de inibição em nenhuma das concentrações testadas. Portanto, apenas os compostos 1, 5, 6, 8 e 10 foram utilizados nos ensaios subsequentes. Os compostos de número 1 e 5 apresentaram os menores valores de $\mathrm{IC}_{50}$, que não diferiram estatisticamente, sendo, assim, os mais eficientes compostos inibidores sobre a atividade esfingomielinásica.

\subsubsection{Atividade hidrolítica sobre o substrato lisofosfatidilcolina (LPC)}

Os compostos $1,5,6,8,10$ e 11 foram também capazes de reduzir a clivagem de LPC pela SMase D, sendo a molécula 10, a mais eficiente com 53\% de inibição (Figura 16A). No 
entanto, foi observado que para o veneno, somente os compostos 1,5 e 8 foram ativos promovendo inibição acima de 20\% (Figura 16B).

Figura 13 - Ação dos inibidores sobre a hidrólise da esfingomielina

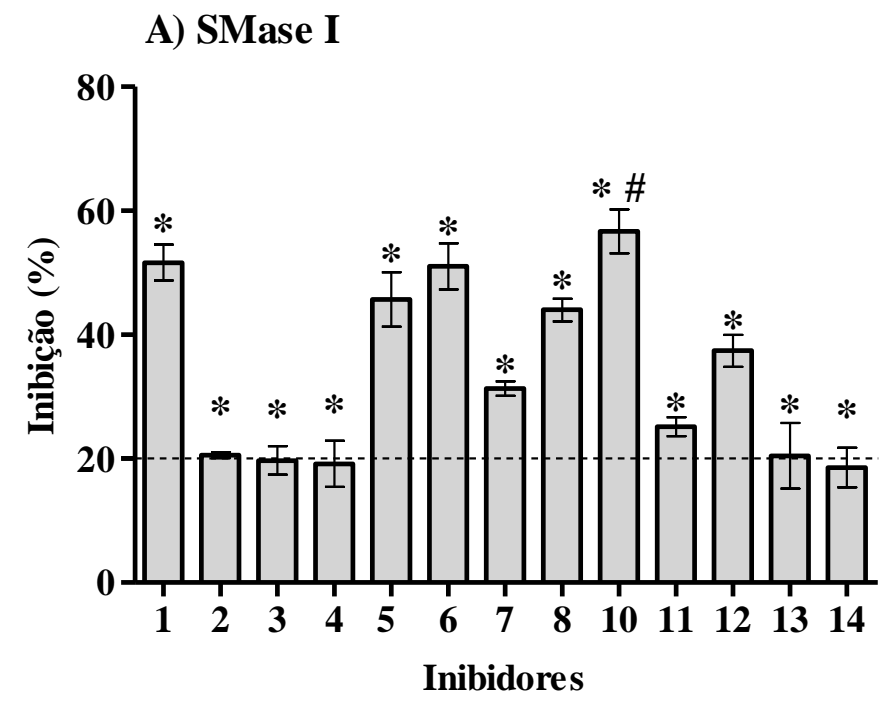

B) Veneno

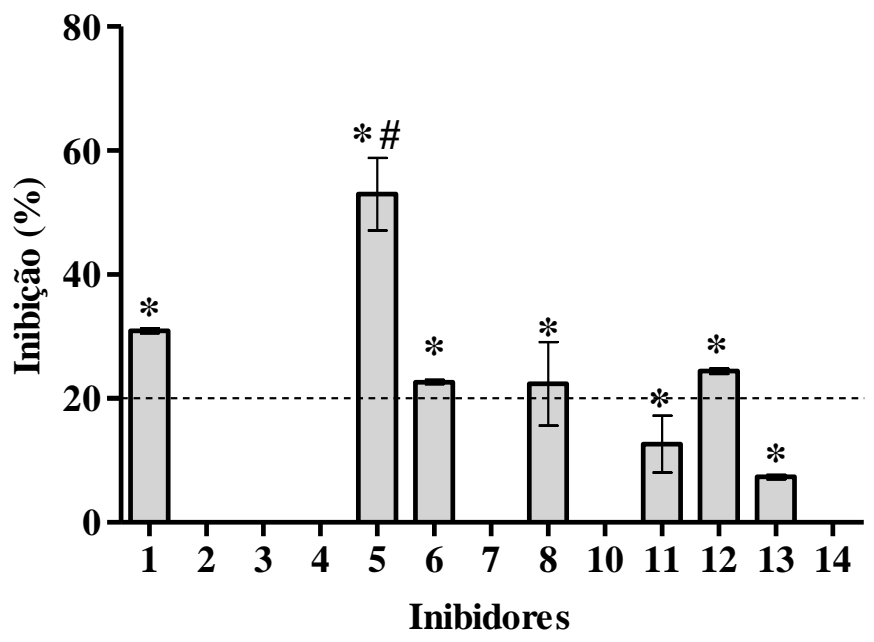

Amostras de esfingomielina $(50 \mu \mathrm{M})$ foram incubadas por 30 min e a $37{ }^{\circ} \mathrm{C}$ com $5 \mu \mathrm{g}$ de SMase I ou $10 \mu \mathrm{g}$ do veneno, previamente incubados ou não com cerca de $40 \mu \mathrm{M}$ de cada inibidor. A liberação de colina, com consequente oxidação à betaína e $\mathrm{H}_{2} \mathrm{O}_{2}$, foi determinada em fluorímetro e a hidrólise expressa em unidades arbitrárias de fluorescência. A) Inibição da atividade da SMase I expressa em porcentagem. B) Inibição da atividade esfingomielinásica do veneno de L. laeta expressa em porcentagem. Os dados estão representados com média \pm erro padrão de duplicatas de quatro experimentos independentes. Analisado estatisticamente por Oneway ANOVA seguido por teste de Tukey HSD em comparação ao controle negativo de inibição. (*) Diferença significativa em relação a um controle negativo de inibição $(p<0,05)$. (\#) Menor valor de $\mathrm{p}$, mostrando a maior diferença significativa $(p<0,0001)$. 
Figura 14 - Curvas dose resposta da inibição da atividade esfingomielinásica
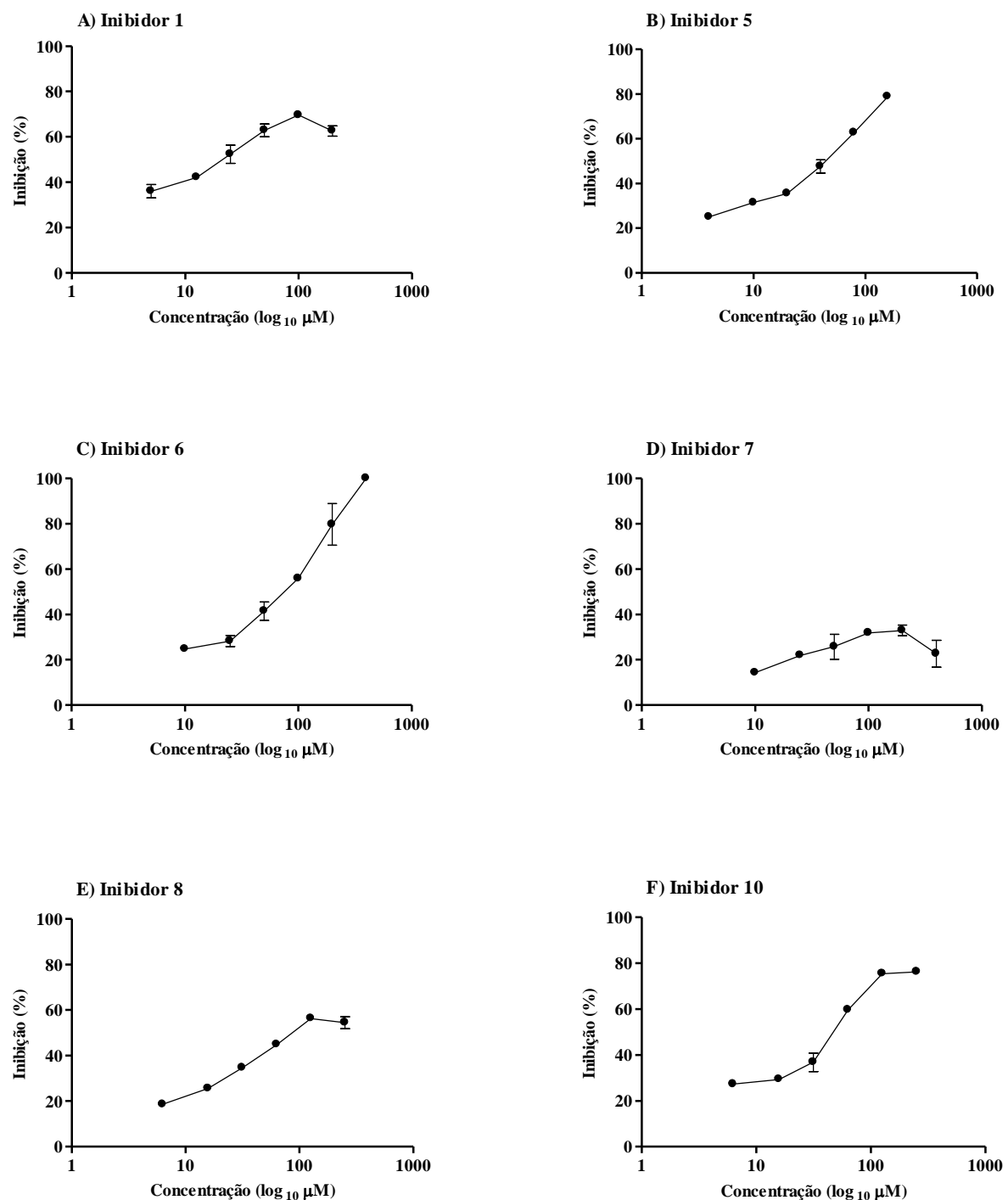

G) Inibidor 11

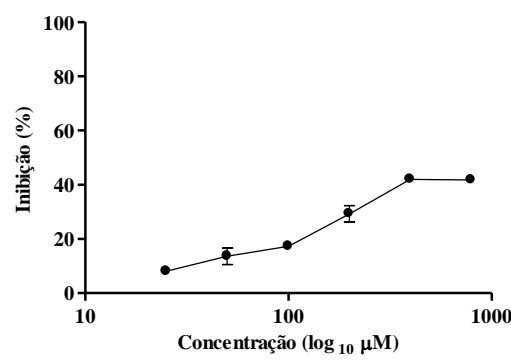

H) Inibidor 12

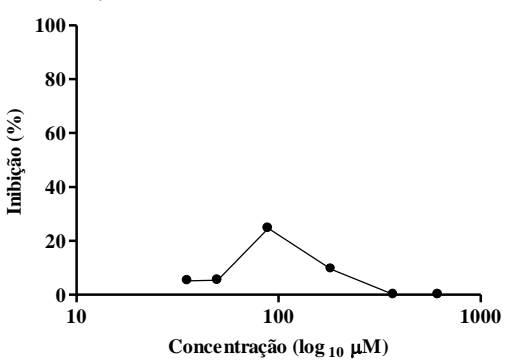

Amostras de esfingomielina $(50 \mu \mathrm{M})$ foram incubadas por 30 min a $37^{\circ} \mathrm{C}$ com $5 \mu \mathrm{g}$ de SMase D previamente incubada ou não com 10 a $200 \mu \mathrm{M}$. A liberação de colina, com consequente oxidação à betaína e $\mathrm{H}_{2} \mathrm{O}_{2}$, foi determinada em fluorímetro e a hidrólise expressa em unidades arbitrárias de fluorescência. Os dados foram expressos como porcentagem de inibição da atividade. . Os dados estão representados com média \pm erro padrão de duplicatas de três experimentos independentes. 
Tabela 4 - Concentração Mínima Inibitória 50\% ( $\left.\mathrm{IC}_{50}\right)$ dos compostos sobre a atividade hidrolítica da SMase I

\begin{tabular}{ccc}
\hline & $\mathbf{R}^{\mathbf{2}}$ & $\mathbf{I C}_{\mathbf{5 0}}(\boldsymbol{\mu M})$ \\
\hline $\mathbf{1}$ & 0,8745 & $48,7 \pm 1,2$ \\
$\mathbf{5}$ & 0,9598 & $45,4 \pm 1,0$ \\
$\mathbf{6}$ & 0,9337 & $63,4 \pm 1,1$ \\
$\mathbf{8}$ & 0,9541 & $73,6 \pm 1,1$ \\
$\mathbf{1 0}$ & 0,9519 & $84,9 \pm 1,1$ \\
\hline
\end{tabular}

$\mathrm{O}$ valor do $\mathrm{IC}_{50}$ foi obtido através do cálculo de regressão não linear das curvas obtidas nos gráficos de porcentagem de inibição da atividade esfingomielinásica versus logaritmo da concentração molar dos compostos estudados. Os gráficos foram construídos com o programa GraphPad Prism, versão 5.00 para Windows, da GraphPad Software (San Diego, EUA).

Figura 15 - Comparação entre os valores de $\mathrm{IC}_{50}$ dos inibidores

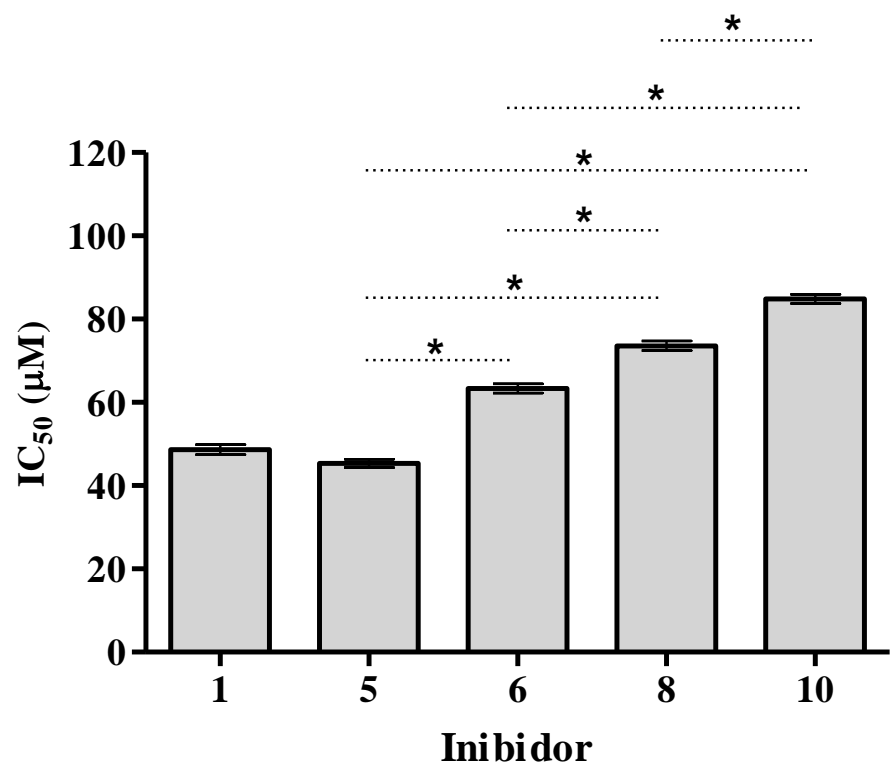

$\mathrm{O}$ valor do $\mathrm{IC}_{50}$, para cada composto foi determinado por análise de regressão não-linear das curvas obtidas nos gráficos de porcentagem de inibição da atividade esfingomielinásica versus logaritmo da concentração molar dos inibidores estudados. Os dados foram analisados estatisticamente por One Way ANOVA seguido pelo pós-teste de Tukey HSD com o software Graph Pad Prisma 5.1. (*) Diferença significativa $p<0,0001$. 
Figura 16 - Ação dos inibidores sobre a hidrólise da lisofosfatidilcolina (LPC)

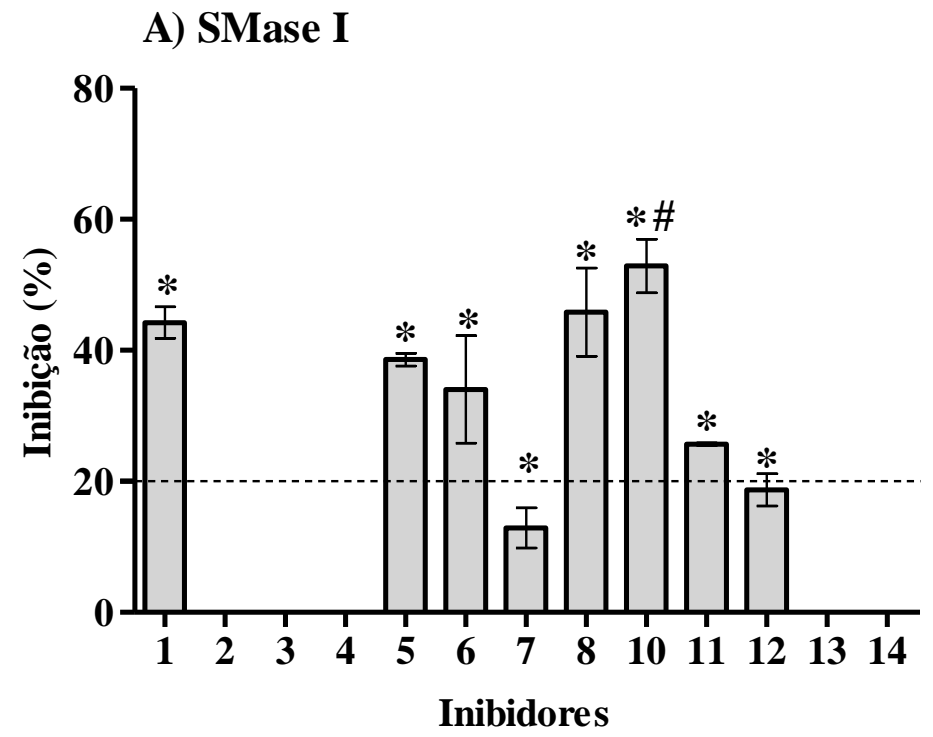

B) Veneno

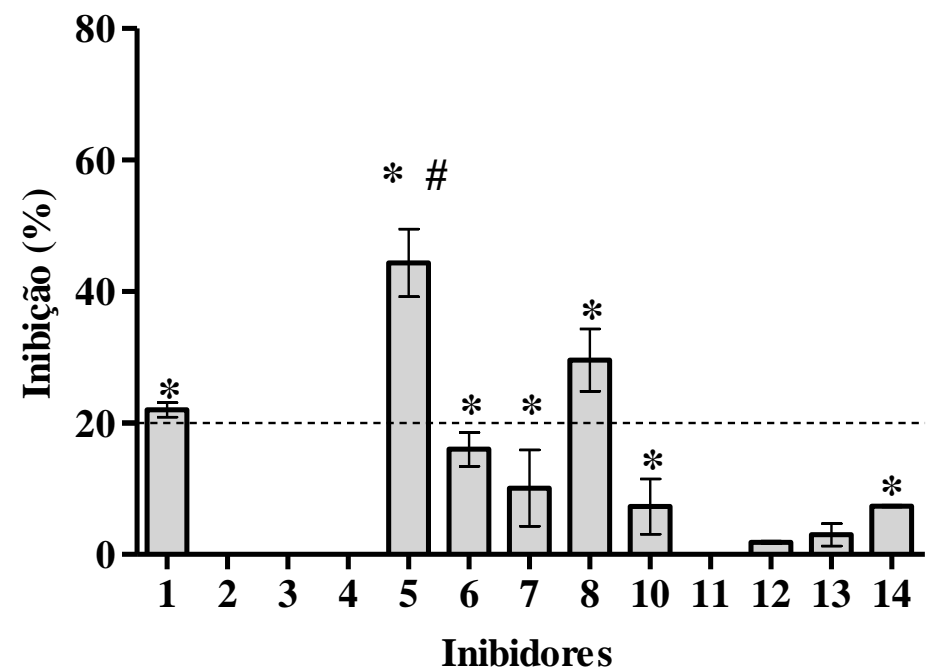

Amostras de LPC $(50 \mu \mathrm{M})$ foram incubadas por 30 min e a $37^{\circ} \mathrm{C}$ com $5 \mu \mathrm{g}$ de SMase I ou $10 \mu \mathrm{g}$ do veneno, previamente incubados ou não com $40 \mu \mathrm{M}$ de cada inibidor. A liberação de colina, com conseqüente oxidação à betaína e $\mathrm{H}_{2} \mathrm{O}_{2}$, foi determinada em fluorímetro e a hidrólise expressa em unidades arbitrárias de fluorescência como no ensaio de hidrólise da esfingomielina. A) Porcentagem de inibição da atividade da SMase I. B) Porcentagem de inibição da atividade do veneno de L. laeta. . Os dados estão representados com média \pm erro padrão de duplicatas de quatro experimentos independentes. Analisado estatisticamente por One-way ANOVA seguido por teste de Tukey HSD em comparação ao controle negativo de inibição. (*) Diferença significativa em relação ao controle negativo de inibição $(p<0,05)$. (\#) Menor valor de $\mathrm{p}$, mostrando a maior diferença significativa $(p<0,0001)$. 


\subsubsection{Análise do mecanismo de inibição}

A equação de Michaelis-Mentem descreve em uma curva semi-hipérbole, o comportamento da velocidade de uma reação enzimática em função da concentração de substrato e, apesar de ser relativamente simples de interpretar, existem tratamentos matemáticos que permitem a determinação dos parâmetros cinéticos com mais rapidez e eficácia e, simplificam a representação gráfica da equação. Um destes tratamentos é a linearização da equação de Michaelis-Mentem conhecida como duplo-recíproco de Linewarver-Burk, no qual um gráfico de 1/V (y) em função de 1/[S] (x) forma uma reta de inclinação igual a $\mathrm{Km} / \mathrm{Vmáx}$ que intercepta o eixo y no ponto $1 / \mathrm{Vmáx}$ e o eixo $\mathrm{x}$ no ponto $-1 / \mathrm{Km}$. Assim, este tratamento permite uma determinação precisa de Vmáx, o que só pode ser obtido por aproximação no gráfico da equação de Michaelis-Mentem (SEGEL, 1975).

Além disso, outra vantagem é que ao usar variadas concentrações do inibidor, este método permite detectar e distinguir de maneira simples, entre diferentes tipos de inibição. $\mathrm{O}$ conjunto de retas formado pelo inverso da velocidade da enzima na ausência e presença de concentrações variadas do inibidor, em função da concentração de substrato, permite diagnosticar o tipo de inibição exercida: (1) retas que se intercruzam sobre o eixo y representam a inibição competitiva; (2) retas que se intercruzam sobre o eixo x, no lado negativo, representam a inibição não competitiva; (3) retas paralelas que não se tocam representam a inibição incompetitiva/acompetitiva e (4) retas que se intercruzam em pontos fora dos eixos x ou y representam a inibição do tipo mista (SEGEL, 1975).

Assim, a análise do mecanismo de inibição pelo método de Linewarver-Burk mostrou que o inibidor 1 exerce um comportamento de inibição mista sobre a atividade da SMase I sobre o substrato esfingomielina, com valor de $K_{i}$ de $1,70 \mu \mathrm{M}$ (Figura 17A). Já os inibidores 5 e 6 exercem inibição da atividade hidrolítica da SMase I por um mecanismo acompetitivo, com valores de $K i$ de 1,63 e 1,73 $\mu \mathrm{M}$, respectivamente (Figura 17B e C).

4.6.5 Ação de inibidores de esfingomielinases celulares endógenas sobre a atividade da SMase I de L. Llaeta

A Figura 18 mostra que Gentamicina e Monensina, quando testadas nas concentrações de 1,5 e $10 \mu \mathrm{g}$, não foram capazes de inibir a atividade hidrolítica da SMase I (5 $\mu \mathrm{g})$ de $L$. laeta. 
Figura 17 - Mecanismo de inibição dos compostos 1, 5 e 6 sobre a atividade hidrolítica da SMase I sobre o substrato esfingomielina

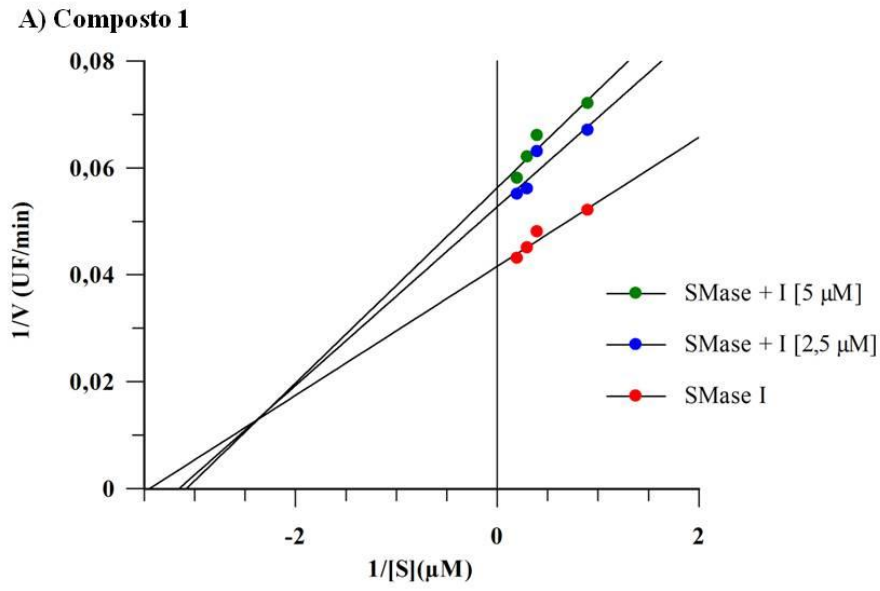

B) Composto 5

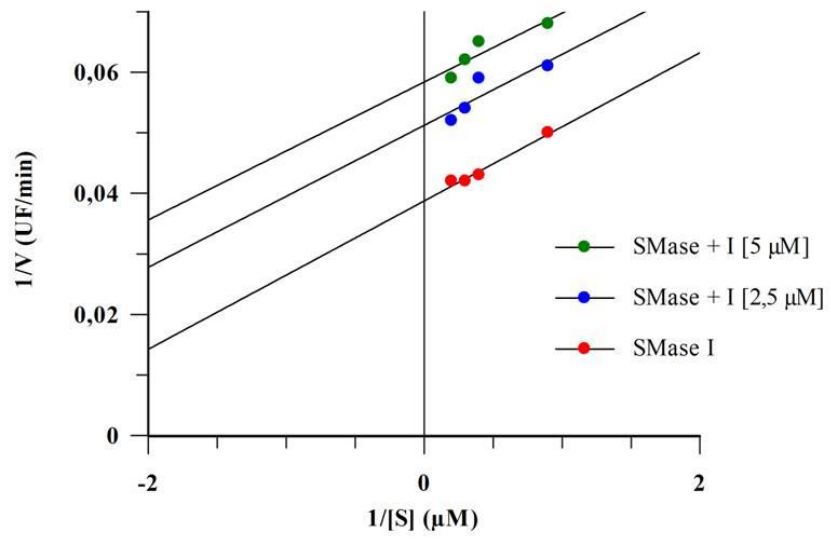

C) Composto 6

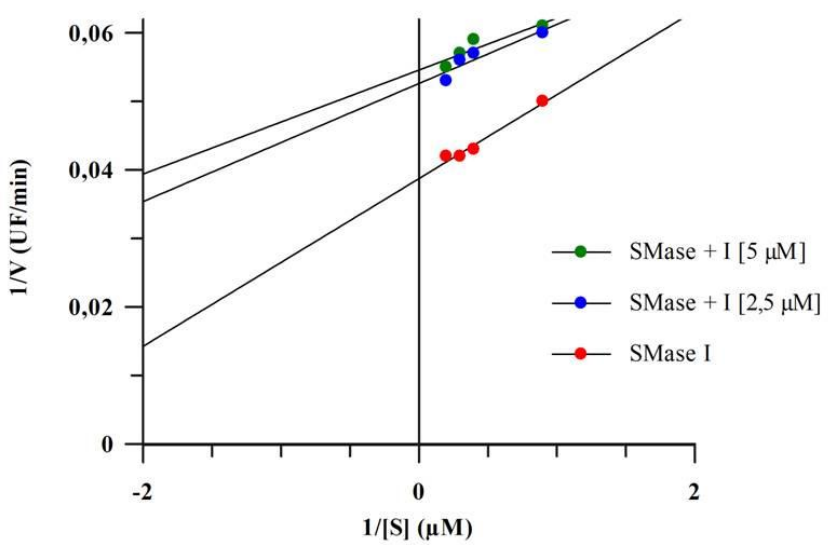

Nestes ensaios foram utilizadas quatro concentrações de substrato $(1,15$ a 4,6 $\mu \mathrm{M})$, sendo que a concentração da enzima foi mantida fixa em $0,5 \mu \mathrm{g}$ e os inibidores foram utilizados nas concentrações de 2,5 e $5 \mu \mathrm{M}$. A liberação de colina, com conseqüente oxidação à betaína e $\mathrm{H}_{2} \mathrm{O}_{2}$, foi determinada em fluorímetro e a hidrólise expressa em unidades arbitrárias de fluorescência como no ensaio de hidrólise da esfingomielina. A) Mecanismo de inibição determinado para o inibidor 1. B) Mecanismo de inibição determinado para o inibidor 5. C) Mecanismo de inibição determinado para o inibidor 6. Os dados estão expressos como a média \pm erro padrão de triplicatas representativo de três experimentos independentes. Para análise foi utilizado o método de plots de Linewarverburk utilizando o software GraFit versão 5.0.6. 
Figura 18 - Análise da ação de inibidores de SMases celulares sobre a atividade hidrolítica da SMase I de L. laeta

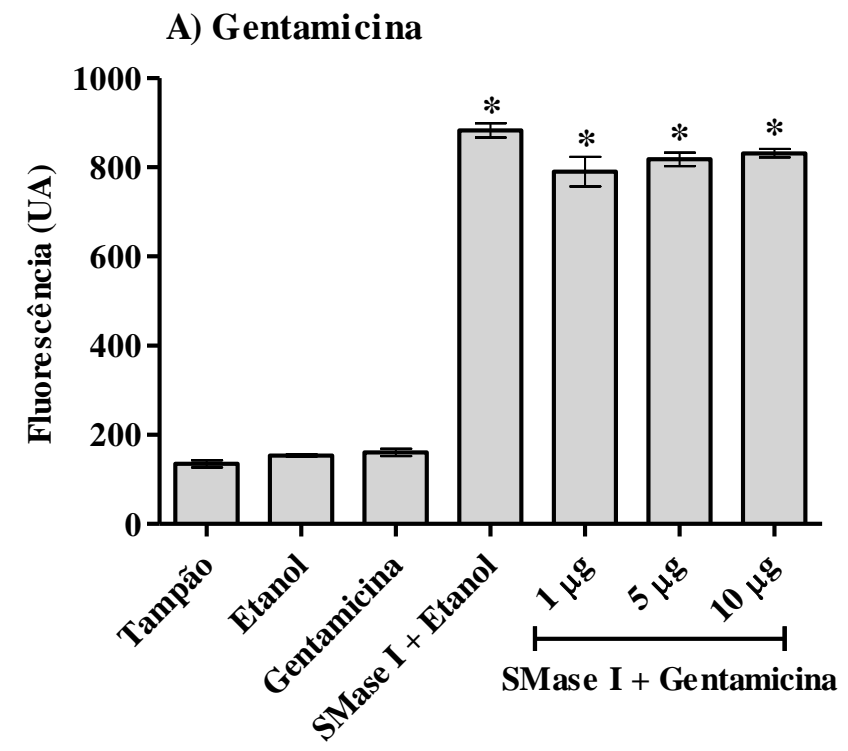

B) Monensina

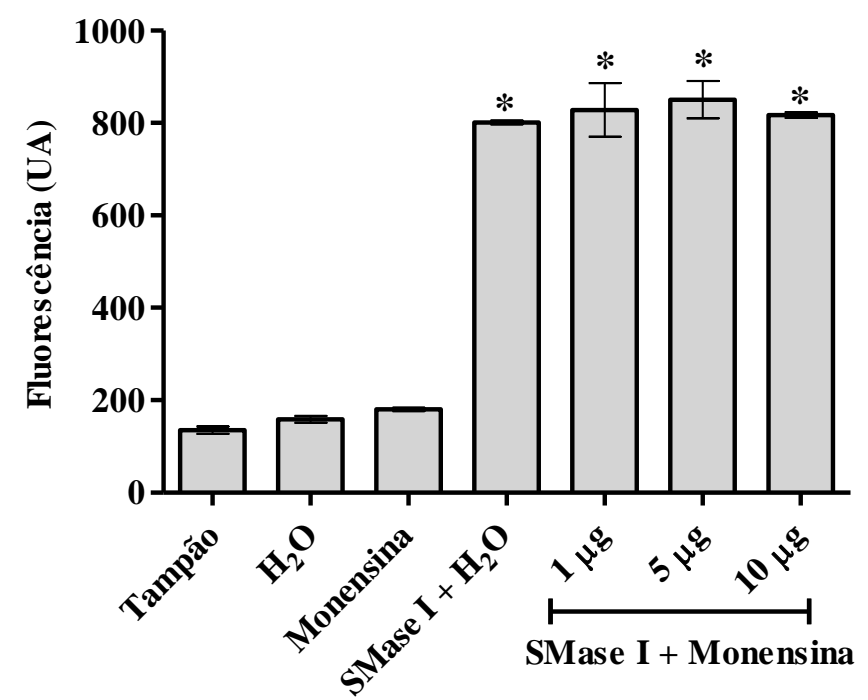

Amostras de esfingomielina $(50 \mu \mathrm{M})$ foram incubadas por 30 min e a $37^{\circ} \mathrm{C}$ com $5 \mu \mathrm{g}$ da SMase I previamente incubada ou não com 1,5 ou $10 \mu \mathrm{g}$ de cada inibidor. A liberação de colina, com conseqüente oxidação à betaína e $\mathrm{H}_{2} \mathrm{O}_{2}$, foi determinada em fluorímetro e a hidrólise expressa em unidades arbitrárias de fluorescência. A) Ação da Gentamicina sobre a atividade da SMase I; B) Ação da Monensina sobre a atividade da SMase D. Os dados estão representados como média \pm erro padrão de duplicatas representativo de dois experimentos independentes. Analisado estatisticamente por One-Way Anova seguido por teste de Tukey HSD. (*) Diferença significativa em relação ao tampão $(p<0,05)$. 


\subsection{Ação dos inibidores sobre o loxoscelismo sistêmico}

4.7.1 Análise do controle da hemólise pelos compostos: avaliação da clivagem de GPC e ligação das SMases D à superfície de eritrócitos humanos

Toxinas isoladas do veneno de $L$. intermedia tornaram eritrócitos humanos susceptíveis a ação do sistema complemento autólogo por induzir a clivagem das porções extracelulares, ricas em ácido siálico, das glicoforinas (A, B e C) da superfície dos eritrócitos, facilitando a ativação da via alternativa do sistema complemento e a hemólise (TAMBOURGI et al., 2000). No ensaio em que a expressão de glicoforina C (GPC) na superfície de eritrócitos foi analisada foi mostrado que os compostos 1, 5, 6, 8 e 10 foram capazes de inibir a clivagem de GPC, induzida pelo veneno de L. laeta (Figura 19A).

O ensaio, em que a ligação das toxinas à superfície de eritrócitos foi investigada, revelou que os compostos 1, 5, 6, 8 e 10 foram capazes de reduzir significativamente a ligação das SMases D, presentes no veneno, às células, sendo o de $\mathrm{n}^{\circ} 5$ o mais eficiente (Figura 19B).

Foram realizadas correlações estatísticas entre as variáveis de inibição da ligação da toxina na superfície da célula e indução da clivagem de glicoforina C. Os resultados mostraram uma correlação significativa de $65 \%$ (p 0,0001), com valor de $-0,6583$ para o r de Pearson, o que indica que as variáveis são inversas, ou seja, quando a ligação da toxina à superfície da célula aumenta, a expressão de glicoforina $\mathrm{C}$ é diminuída e vice-versa (Figura 20). 
Figura 19 - Análise da capacidade dos compostos em inibir a ligação das SMases D à superfície de eritrócitos e induzir a clivagem da glicoforina C (GPC)

A)

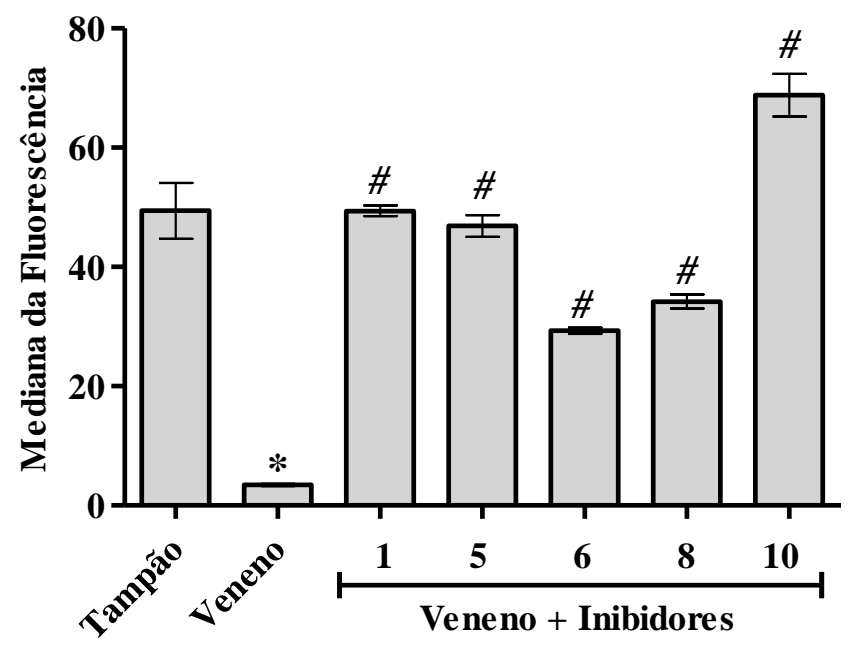

B)

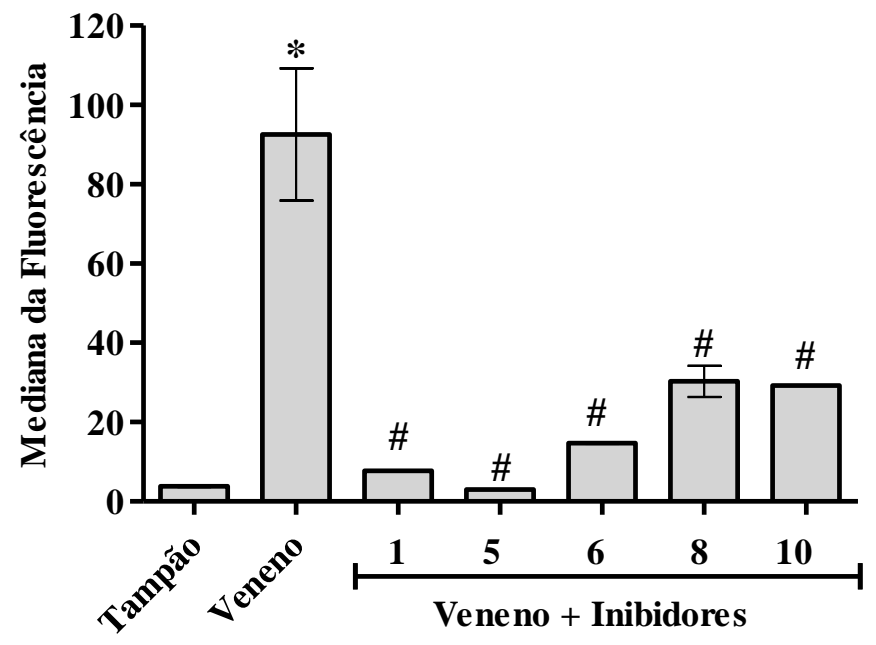

Eritrócitos humanos foram tratados com $2,5 \mu \mathrm{g}$ do veneno de L. laeta incubados ou não com $40 \mu \mathrm{M}$ de cada inibidor e analisados quanto à expressão de GPC por citometria de fluxo. A habilidade das toxinas em se ligar à superfície dos eritrócitos foi analisada usando um soro policlonal monoespecífico de coelho contra SMases D de L. intermedia. A) Remoção de GPC induzida pelo veneno de L. laeta. B) Ligação das SMases do veneno à superfície de eritrócitos. Os dados estão representados como média \pm erro padrão de duplicatas representativo de dois experimentos independentes. Analisado estatisticamente por One-Way ANOVA seguido por teste de Tukey HSD. (*) Diferença significativa em relação ao tampão ( $p<0,05)$. (\#) Diferença significativa em relação ao veneno de L. laeta $(p<0,05)$. 
Figura 20 - Representação da correlação estatística entre a ligação da toxina à membrana do eritrócito versus clivagem de glicoforina $\mathrm{C}$

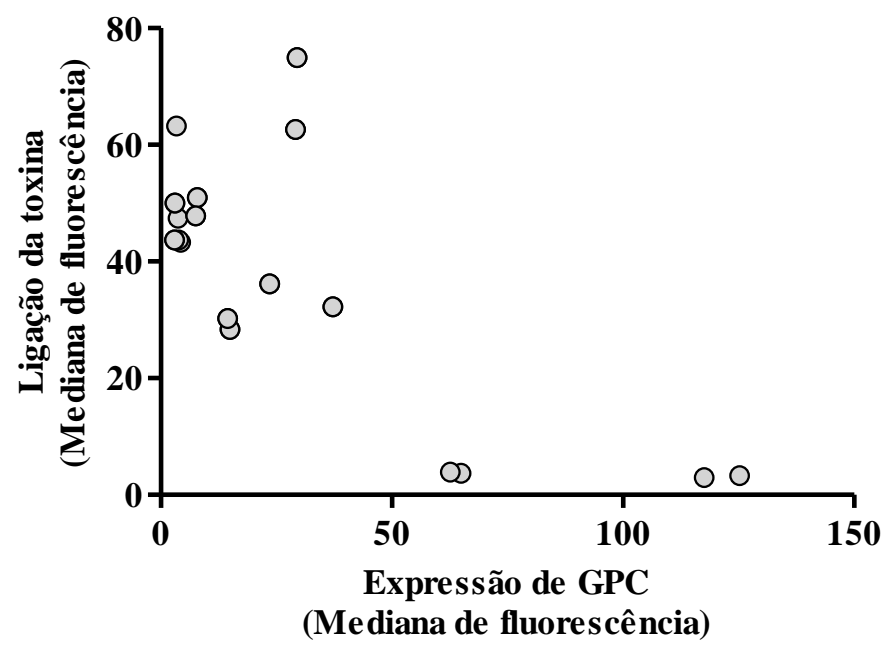

Correlação estatística de Pearson realizada a partir dos dados de dois experimentos independentes. Os dados foram analisados estatisticamente e a correlação calculada utilizando o software GraphPad Prisma 5.1

\subsubsection{Análise da ação dos inibidores sobre o potencial letal do veneno}

Grupos de quatro camundongos BALB/c foram inoculados pela via subcutânea com três diferentes doses do veneno de L. laeta $(2,5 ; 5,0$ e $10 \mu \mathrm{g})$ e acompanhados durante 72 horas. A análise do número de animais mortos em cada dose utilizando o sistema Probit mostrou que a $\mathrm{DL}_{50}$ determinada para o veneno de L. laeta foi de 7,039 $\mu \mathrm{g} / \mathrm{animal}$ ou 0,352 $\mathrm{mg} / \mathrm{kg}$.

Para os ensaios com os inibidores, grupos de quatro camundongos foram inoculados pela via subcutânea com $14 \mu \mathrm{g}$ de veneno de L. laeta (2 DL 50$)$, incubado com os inibidores 1 , 5 ou 6 na concentração equivalente a 3 IC $_{50}(145,95 ; 136,08$ e 190,08 $\mu \mathrm{M}$, respectivamente). Os grupos controles foram inoculados apenas com salina ou veneno. Os resultados obtidos mostraram que os inibidores não foram capazes de proteger os animais da letalidade do veneno de L. laeta. 


\subsection{Ação dos inibidores sobre o loxoscelismo cutâneo}

\subsubsection{Análise da viabilidade celular de queratinócitos humanos}

Tambourgi et al. (2005) e Paixão-Cavalcante et al. (2006) demonstraram em estudos in vivo, em coelhos, e, in vitro, em queratinócitos humanos da linhagem HaCat, o aumento na expressão/secreção das metaloproteases de matriz extracelular, MMP-2 e MMP-9, diminuição da viabilidade celular por apoptose e aumento do infiltrado inflamatório no local da lesão, na presença do veneno ou das SMases D de Loxosceles. Portanto, os mecanismos do loxoscelismo cutâneo incluem a ligação das SMases D de Loxosceles aos queratinócitos e indução de morte celular.

Após 72 horas de incubação das células com o veneno/SMase I na presença dos inibidores, foi possível observar que os compostos 1, 5 e 6 foram capazes de inibir significativamente a morte celular dos queratinócitos humanos induzida pelo veneno e pela toxina L. laeta (Figura 21). 
Figura 21 - Viabilidade de células HaCat tratadas com SMase I ou veneno de L. laeta na presença ou ausência dos inibidores

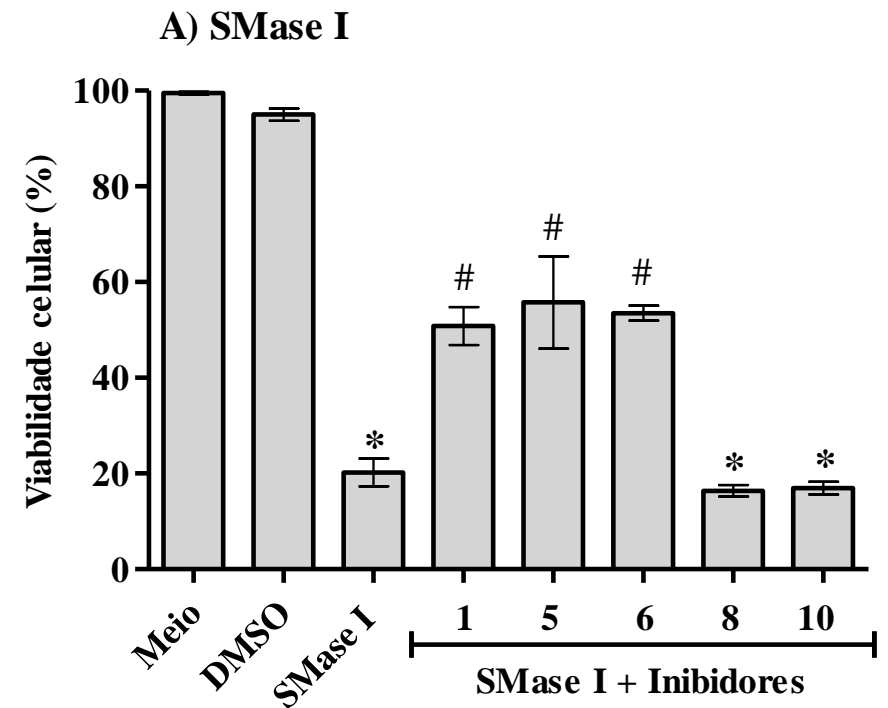

B) Veneno

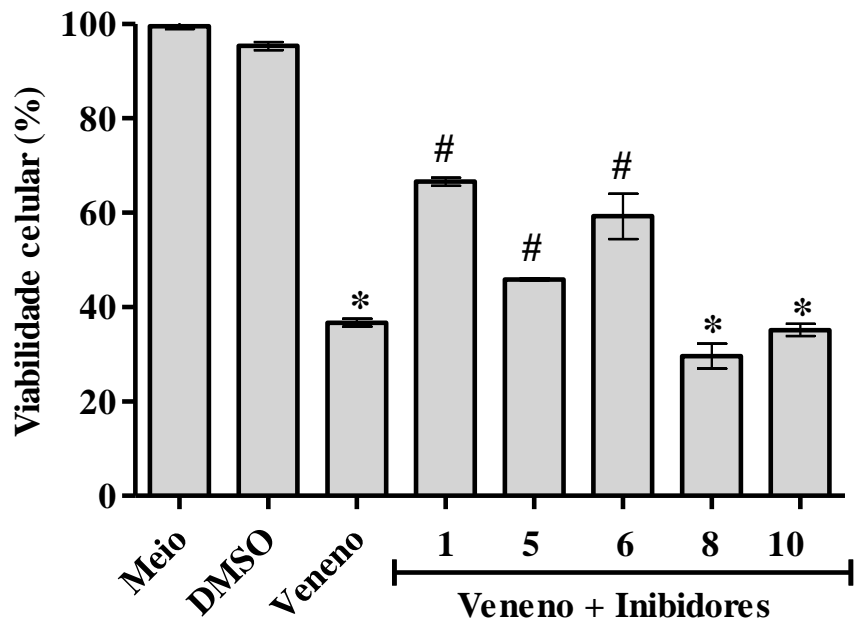

Células HaCat $\left(5 \times 10^{4} / \mathrm{mL}\right)$ foram tratadas com amostras de $5 \mu \mathrm{g}$ de SMase I ou $10 \mu \mathrm{g}$ de veneno de L. laeta, pré-incubados ou não com $10 \mu \mathrm{M}$ de cada inibidor. A morte celular foi avaliada após 72 horas de incubação, pelo método de MTT. A) Ação dos inibidores sobre a morte celular induzida pela SMase D. B) Ação dos inibidores sobre a morte celular induzida pelo veneno de $L$. laeta. Os dados estão representados como média \pm erro padrão de duplicatas representativo de três experimentos independentes. Analisado estatisticamente por One-Way ANOVA seguido por teste de Tukey HSD. (*) Diferença significativa em relação ao tampão $(p<0,05)$; (\#) Diferença significativa em relação à SMase $\mathrm{D}$ e ao veneno $(p<0,05)$. 
4.8.2 Ação dos inibidores sobre a ligação das SMases $D$ à superfície de queratinócitos humanos

Nestes ensaios a capacidade dos inibidores em interferir com a ligação das SMases D à superfície de queratinócitos humanos foi investigada e os resultados mostraram que tanto para o veneno de L. laeta, quanto para a toxina, os compostos 5, 6, 8 e 10 foram capazes de reduzir significativamente a ligação das SMases D à superfície destas células (Figura 22).

Assim como nos eritrócitos, a análise por correlação estatística entre as variáveis de inibição da ligação da toxina à superfície da célula e viabilidade celular mostrou de maneira significativa (p 0,0002) uma correlação de 65\% com valor de $r$ de Pearson de -0,6547, indicando que as variáveis também são inversas, ou seja, quanto maior a ligação da toxina à membrana, menor é a viabilidade celular e vice-versa (Figura 23). 
Figura 22 - Análise da capacidade dos compostos em inibir a ligação das SMases D à superfície de queratinócitos humanos

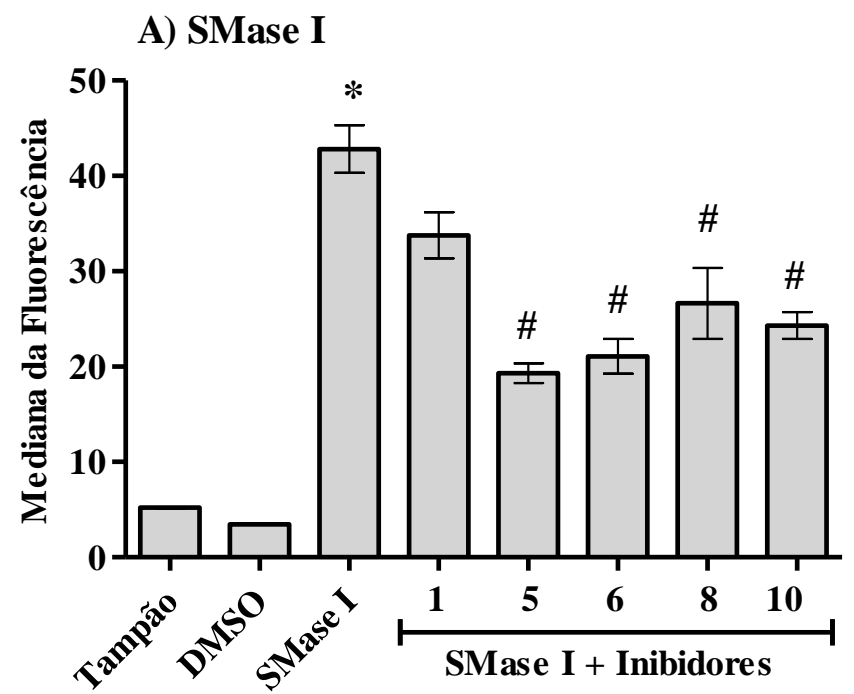

B) Veneno

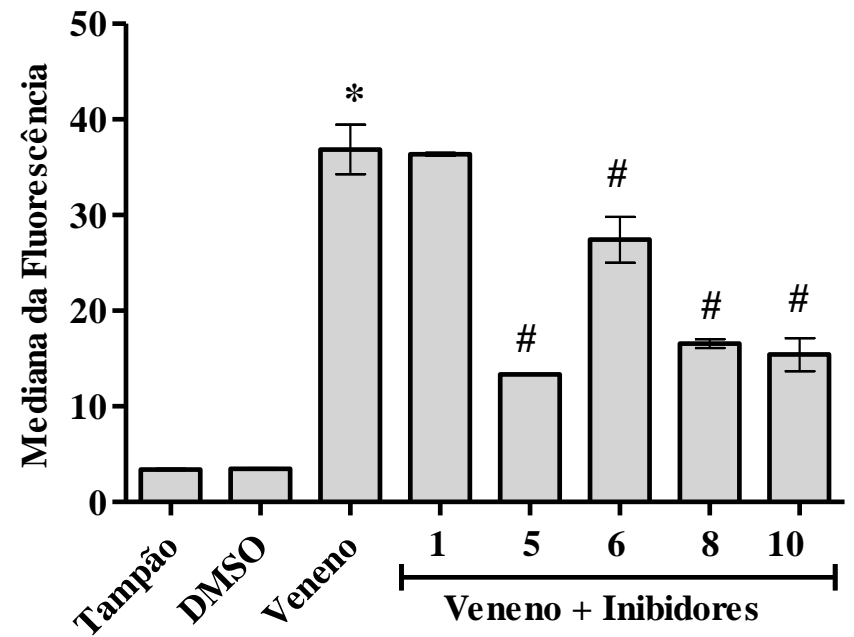

Queratinócitos humanos foram tratados com $10 \mu \mathrm{g}$ do veneno de L. laeta ou $5 \mu \mathrm{g}$ de SMase I, incubados ou não com $40 \mu \mathrm{M}$ de cada inibidor e analisados por citometria de fluxo quanto a habilidade das toxinas em se ligar à superfície dos queratinócitos usando soro policlonal monoespecífico de cavalo contra SMases D de Loxosceles. A) Ligação das SMase I à superfície de queratinócitos humanos. B) Ligação das SMases D do veneno de L. laeta à superfície de queratinócitos humanos. Os dados estão representados como média \pm erro padrão representativo de dois experimentos independentes. Analisado estatisticamente por One-Way ANOVA seguido por teste de Tukey HSD. (*) Diferença significativa em relação ao tampão $(p<0,05)$. (\#) Diferença significativa em relação ao veneno de L. laeta ou a SMase I $(p<0,05)$. 
Figura 23 - Representação da correlação estatística entre a ligação da toxina à membrana do queratinócito versus viabilidade celular

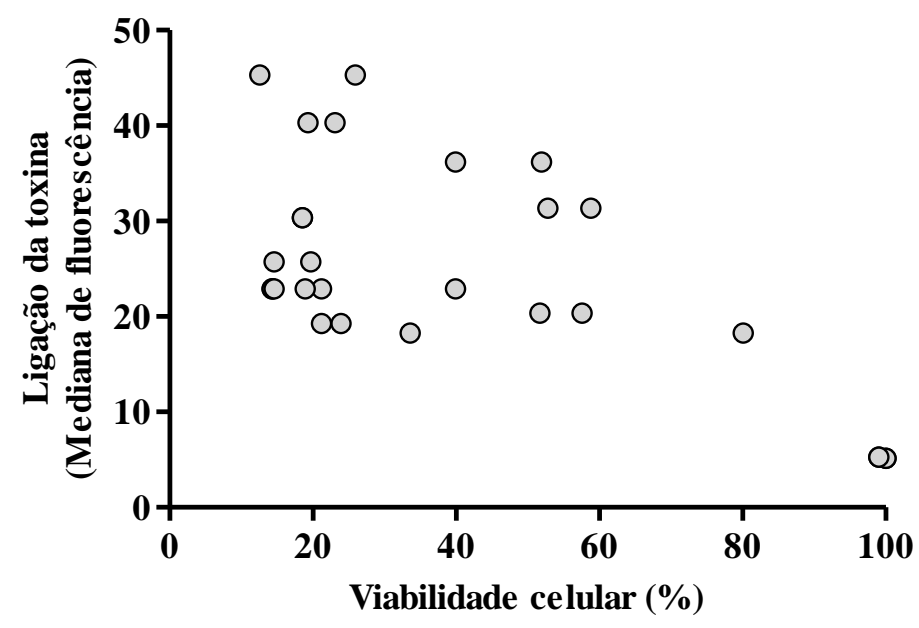

Correlação estatística de Pearson realizada a partir dos dados de dois experimentos independentes. Os dados foram analisados estatisticamente e a correlação calculada utilizando o software GraphPad Prisma 5.1

\subsubsection{Ação dos inibidores sobre a produção de MMPs por queratinócitos humanos}

Como demonstrado por Tambourgi et al. (2005) e Paixão-Cavalcante et al. (2006), o aumento da expressão de MMP-2 e 9 pela ação do veneno de Loxosceles e suas toxinas é um evento importante na indução da morte celular e formação da lesão cutânea presente no loxoscelismo.

A figura 24A mostra que o veneno foi capaz de induzir aumento significativo de MMP-9 no sobrenadante de culturas de queratinócitos e que os inibidores 1, 5 e 6 foram capazes de reduzir significativamente a expressão/secreção desta molécula. Em relação à MMP-2, o veneno foi também capaz de aumentar a expressão/secreção em relação às células tratadas apenas com meio, sendo possível observar que os cinco inibidores testados foram capazes de interferir com a expressão/secreção da MMP-2 (Figura 24B). 
Figura 24 - Dosagem de MMP-2 e 9 no sobrenadante de cultura de queratinócitos tratados com veneno de L. laeta na presença ou ausência dos inibidores

A) MMP-9

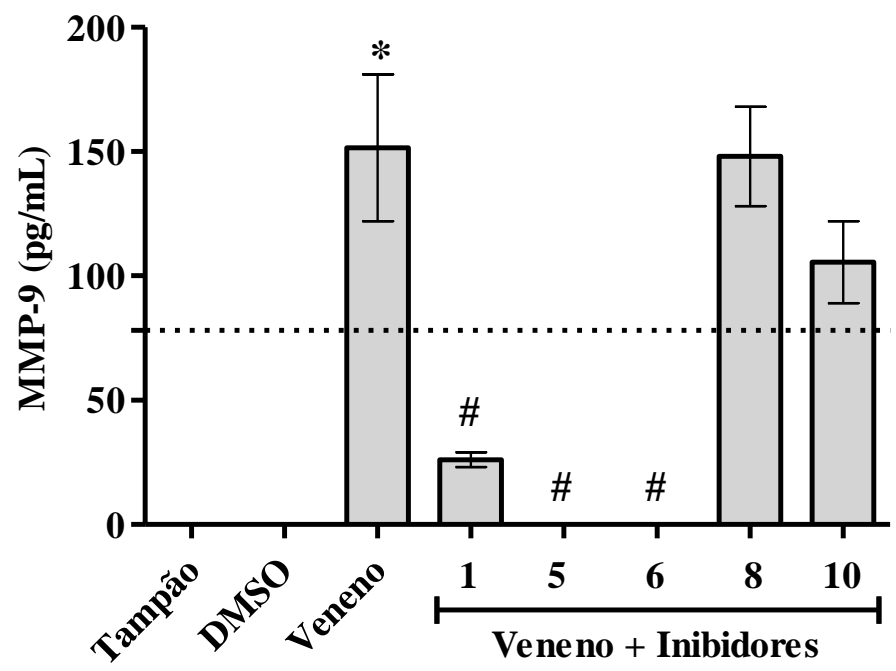

B) MMP-2

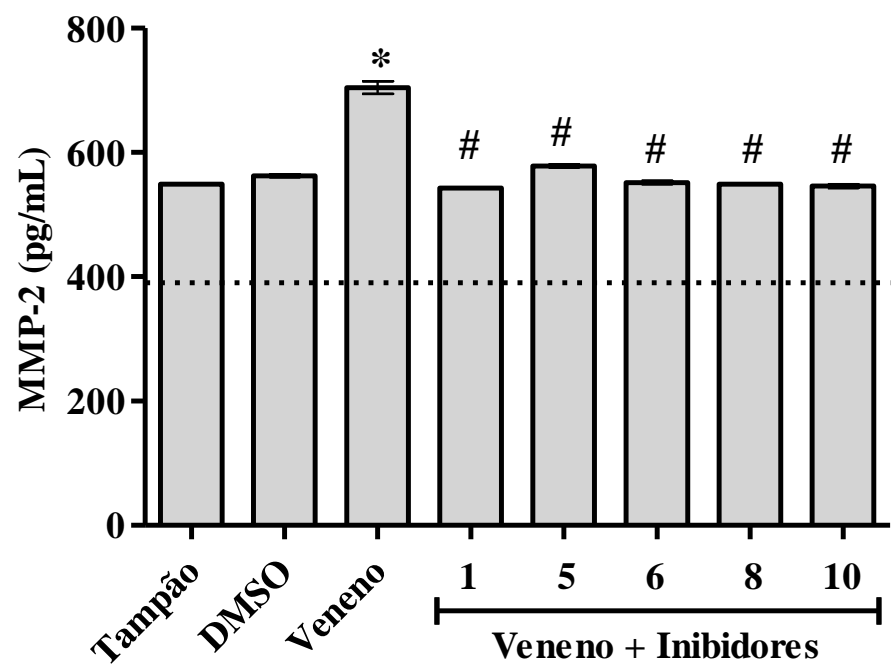

Células HaCat $\left(5 \times 10^{4} / \mathrm{mL}\right)$ foram tratadas com amostras de $10 \mu \mathrm{g}$ do veneno de L. laeta incubado ou não com 10 $\mu \mathrm{M}$ dos inibidores ou tampão por 72 horas e foram analisadas quanto a detecção de MMP-2 e 9 utilizando o Calbiochem MMP-2 e 9 ELISA Kits. A) Detecção de MMP-9 após tratamento de células HaCat com veneno incubado ou não com os inibidores por 72 horas. B) Detecção de MMP-9 após tratamento de células HaCat com veneno incubado ou não com os inibidores por 72 horas. Os dados estão representados como média \pm erro padrão de duplicatas representativo de dois experimentos independentes. Analisado estatisticamente por One Way ANOVA seguido por teste de Tukey HSD. (*) Diferença significativa em relação ao tampão $(p<0,05)$; (\#) Diferença significativa em relação ao veneno $(p<0,05)$. 
4.8.4 Ação dos inibidores sobre a dermonecrose induzida pelo veneno de $\underline{\text { L. laeta em coelhos }}$

A habilidade dos inibidores em reduzir a lesão dermonecrótica induzida por $5 \mu \mathrm{g}$ do veneno de L. laeta foi avaliada pela inoculação do veneno incubado com os inibidores 1, 5, 6, 8 e 10 na concentração equivalente a 3 IC $_{50}(145,95 ; 136,08 ; 190,08 ; 220,8 ; 254,55 \mu \mathrm{M}$, respectivamente). Os animais receberam solução salina estéril, veneno incubado com a mesma proporção de DMSO presente nos inibidores, somente DMSO ou inibidores, como controles.

Foi possível observar a formação de uma lesão típica com edema, eritema e aumento da temperatura no local da inoculação. Dentro de 24 horas a dermonecrose foi observada e a medida da área das lesões foi acompanhada por 72 horas após a inoculação do veneno. A figura 25 mostra que apenas os inibidores 5 e 6 foram capazes de reduzir a área e a progressão das lesões. A inoculação de salina, DMSO ou inibidores, na ausência de veneno, não produziu qualquer lesão nos animais.

A análise do tamanho das lesões 24 horas após inoculação revelou que o tratamento com os inibidores 5 e 6 resultou em inibições de 61,84 e 39,97\%, respectivamente, e não mais do que $20 \%$ para os demais. Após 48 horas, a inibição induzida pelo composto 5 se manteve em torno de $60 \%$ e para o 6 foi de $45 \%$. Às 72 horas, a inibição foi de $56 \%$ para o inibidor 5 e de $49 \%$ para o 6. Para os demais compostos as porcentagens de inibição foram calculadas em 48 e 72 horas não foram superiores a 20\% (Figura 26).

Utilizando concentrações equivalentes a 1,2 e $3 \mathrm{IC}_{50}$, foi realizada uma análise de dose/resposta dos inibidores 5 e 6 . O ensaio revelou que, em 24, 48 e 72 horas, o composto 5 foi capaz de promover inibição nas três concentrações e tempos analisados; no entanto, sem diferenças estatísticas entre as doses testadas (Figura 27). Já o composto 6 foi capaz de reduzir significativamente a lesão dermonecrótica somente na maior concentração utilizada (Figura 28). 
Figura 25 - Ação dos inibidores sobre dermonecrose induzida pelo veneno de L. laeta in vivo
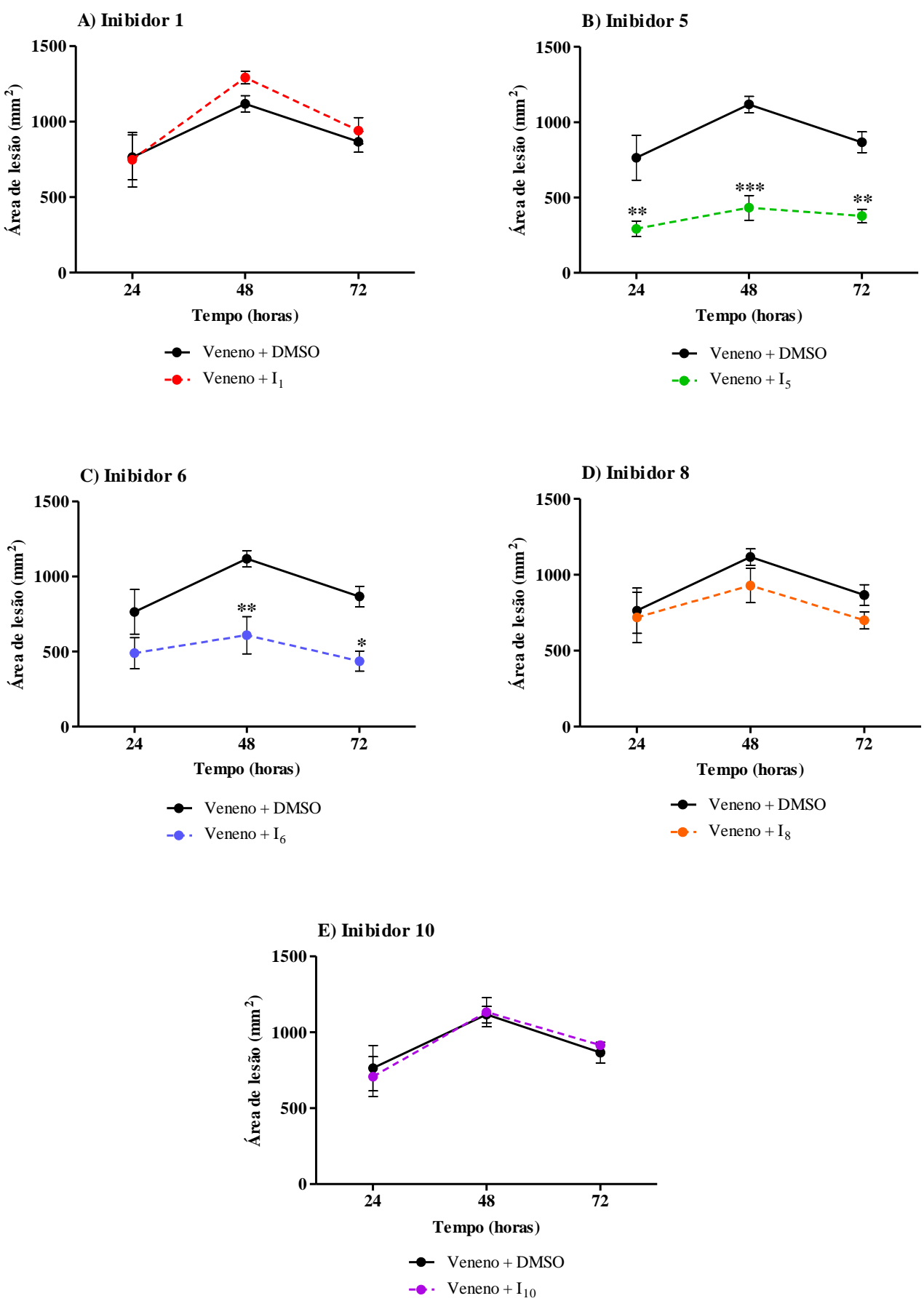

Animais foram inoculados via intradérmica com $5 \mu \mathrm{g}$ do veneno de L. laeta na presença ou ausência dos inibidores na concentração de $3 \mathrm{IC}_{50}$. Solução salina estéril, veneno incubado com a mesma proporção de DMSO presente nos inibidores, somente DMSO ou somente inibidores foram utilizados como controles. A área da lesão dermonecrótica foi medida em 24, 48 e 72 horas. Os dados estão representados como média \pm erro padrão de duplicatas de dois experimentos independentes $(n=12$ coelhos). Analisado estatisticamente por Two Way ANOVA seguido pelo pós-teste de Bonferroni. (*), utilizando o programa GraphPad Prisma 5.1. Diferença significativa em relação ao veneno + DMSO no tempo indicado $(p<0,05) ;(* *) p<0,01 ;(* * *) p<0,001$. 
Figura 26 - Porcentagem de inibição da lesão dermonecrótica induzida pelo veneno de L. laeta in vivo

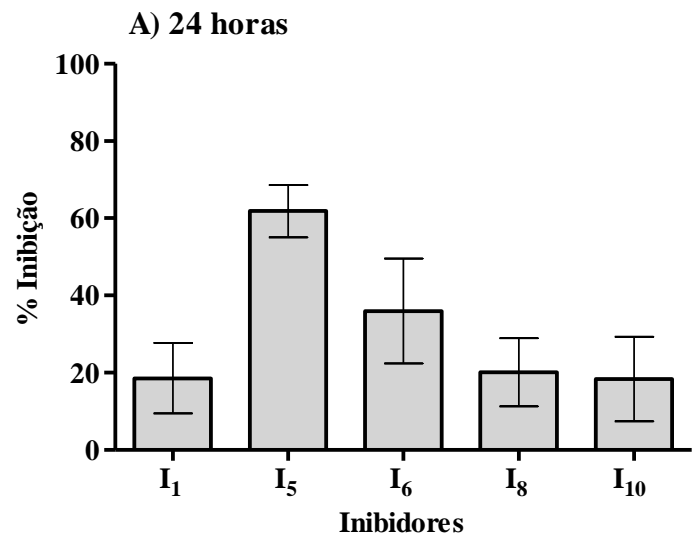

B) 48 horas

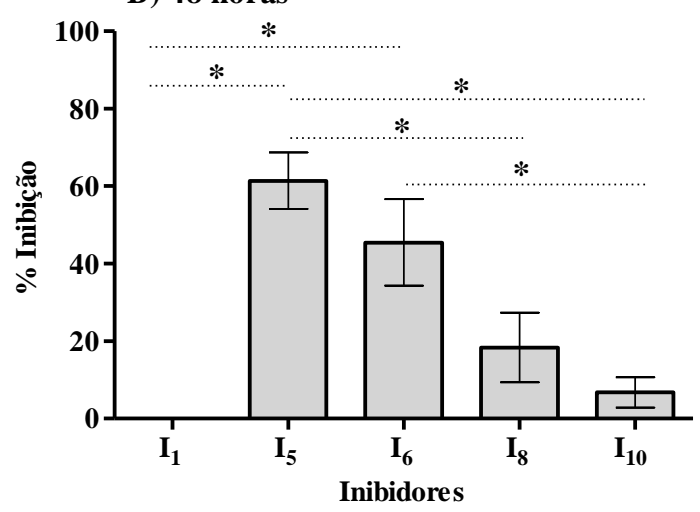

C) 72 horas

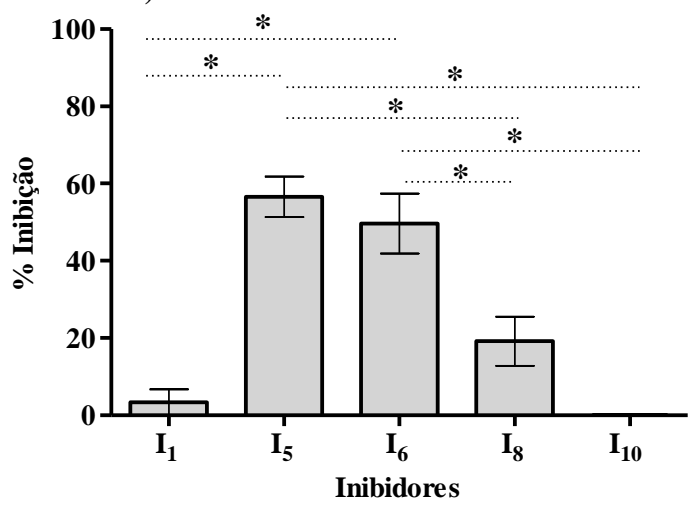

Animais foram inoculados via intradérmica com $5 \mu \mathrm{g}$ do veneno de L. laeta na presença ou ausência dos inibidores na concentração de $3 \mathrm{IC}_{50}$. Solução salina estéril, veneno incubado com a mesma proporção de DMSO presente nos inibidores, somente DMSO ou somente inibidores foram utilizados como controles. A área da lesão dermonecrótica foi medida em 24, 48 e 72 horas. Os dados estão representados como média \pm erro padrão de duplicatas de dois experimentos independentes ( $\mathrm{n}=12$ coelhos). Analisado estatisticamente por One Way ANOVA seguido pelo pós-teste de Tukey HSD, utilizando o programa GraphPad Prisma 5.1. (*) Diferença significativa em relação ao veneno $(p<0,05)$. 
Figura 27 - Curva dose resposta do inibidor 5 sobre a lesão dermonecrótica induzida pelo veneno de L. laeta in vivo

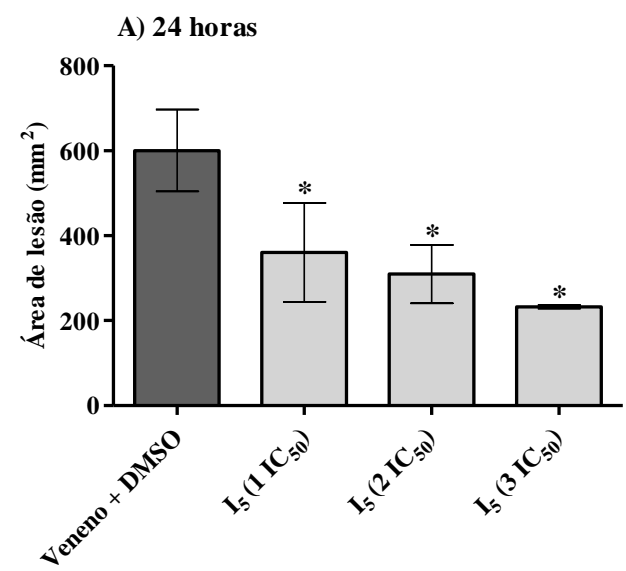

B) 48 horas

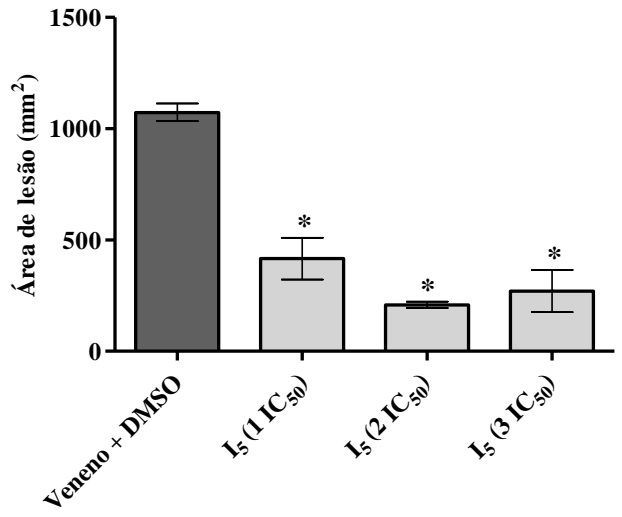

C) 72 horas

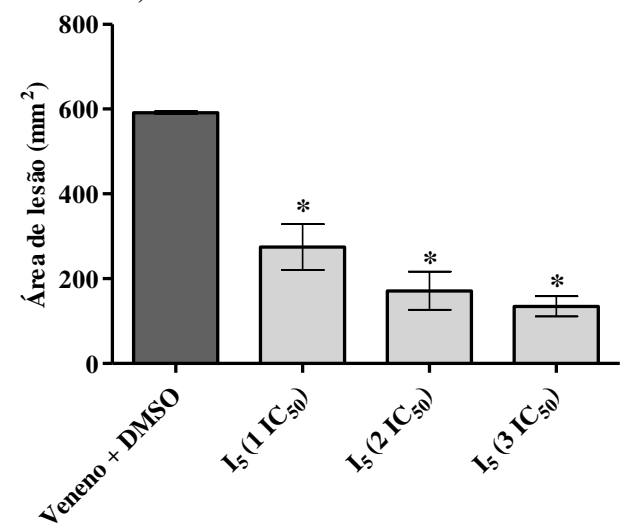

Animais foram inoculados via intradérmica com $5 \mu \mathrm{g}$ do veneno de L. laeta na presença ou ausência dos inibidores na concentração de $3 \mathrm{IC}_{50}$. Solução salina estéril, veneno incubado com a mesma proporção de DMSO presente nos inibidores, somente DMSO ou somente inibidores foram utilizados como controles. A área da lesão dermonecrótica foi medida em 24, 48 e 72 horas. Os dados estão representados como média \pm erro padrão de duplicatas de dois experimentos independentes $(n=12$ coelhos $)$. Analisado estatisticamente por One Way ANOVA seguido pelo pós-teste de Tukey HSD, utilizando o programa GraphPad Prisma 5.1. (*) Diferença significativa em relação ao veneno $(p<0,05)$. 
Figura 28 - Curva dose reposta do inibidor 6 sobre a lesão dermonecrótica induzida pelo veneno de L. laeta in vivo
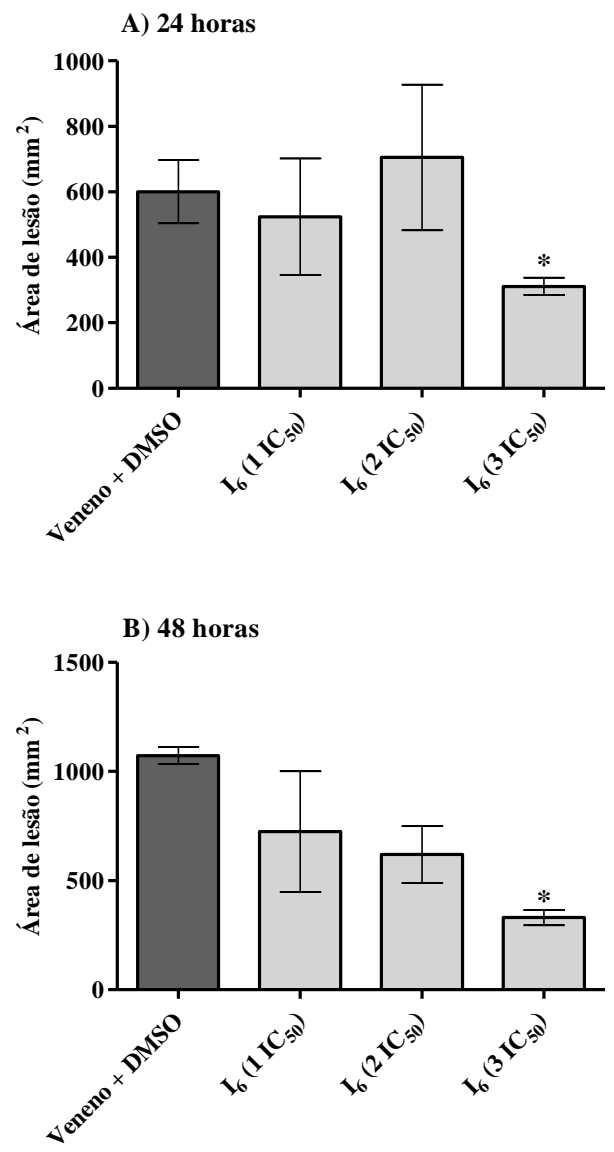

C) 72 horas

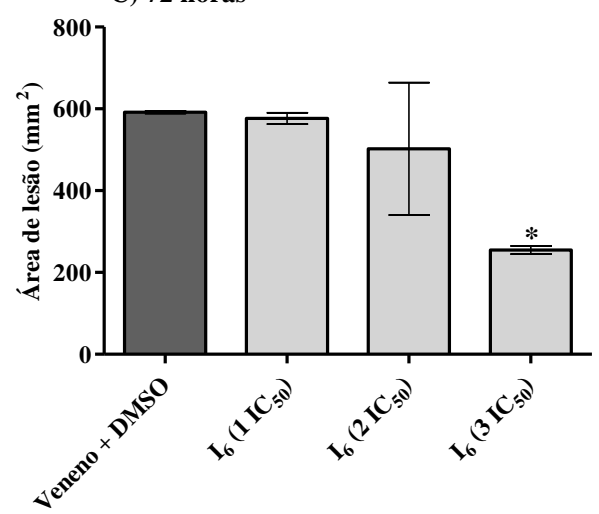

Animais foram inoculados via intradérmica com $5 \mu \mathrm{g}$ do veneno de L. laeta na presença ou ausência dos inibidores na concentração de $3 \mathrm{IC}_{50}$. Solução salina estéril, veneno incubado com a mesma proporção de DMSO presente nos inibidores, somente DMSO ou somente inibidores foram utilizados como controles. A área da lesão dermonecrótica foi medida em 24, 48 e 72 horas. Os dados estão representados como média \pm erro padrão de duplicatas de dois experimentos independentes ( $\mathrm{n}=12$ coelhos). Analisado estatisticamente por One Way ANOVA seguido pelo pós-teste de Tukey HSD, utilizando o programa GraphPad Prisma 5.1. (*) Diferença significativa em relação ao veneno $(p<0,05)$. 


\subsubsection{Análise histopatológica das lesões dermonecróticas}

A análise histopatológica de fragmentos de pele, dos coelhos inoculados com $5 \mu \mathrm{g}$ do veneno de L. laeta, mostrou que este foi capaz de induzir hemorragia, infiltrado inflamatório denso, desorganização do colágeno e lesão da camada muscular adjacente com hemorragia e infiltrado celular (Figura 29A, A1 e A2).

$\mathrm{Na}$ presença do inibidor 5 e 6 foi possível observar uma grande redução das áreas hemorrágicas e do infiltrado celular. A desorganização do colágeno também foi reduzida e a camada muscular adjacente mostrou-se íntegra (Figura 30A, A1, A2 e B, B1, B2). No entanto, na presença das moléculas 1, 8 e 10 não houve redução das áreas hemorrágicas e o infiltrado celular persistiu, assim como a grande desorganização das fibras colágenas e a lesão na camada muscular adjacente (Figura 29B, B1, B2, 31A, A1, A2 e B, B1, B2). 
Figura 29 - Análise histopatológica de fragmentos de pele de coelhos inoculados com veneno de L. laeta na presença ou ausência do inibidor 1
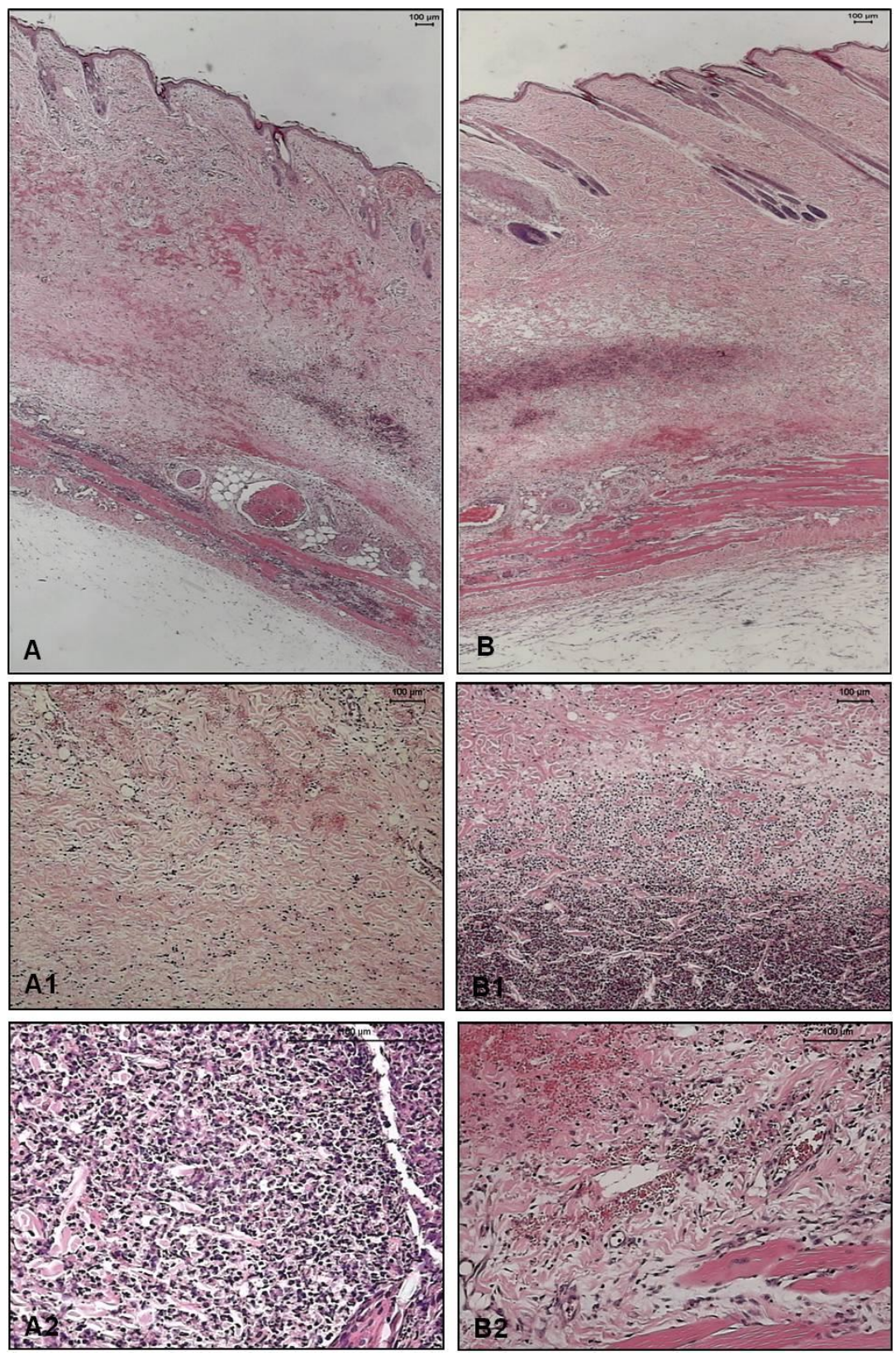

Fragmentos de pele de coelhos inoculados com $5 \mu \mathrm{g}$ de veneno de L. laeta na ausência ou presença do inibidor 1 na concentração de $3 \mathrm{IC}_{50}(145,95 \mu \mathrm{M})$ foram retirados 72 horas após a inoculação e fixados em formol $4 \% \mathrm{pH}$ 7,4. As amostras foram encaminhadas para a confecção de lâminas histológicas permanentes coradas com Hematoxilina-Eosina. A) Aspecto geral do fragmento de pele inoculado com $5 \mu \mathrm{g}$ de veneno na ausência de inibidores (aumento 5x). A1) Detalhe de áreas hemorrágicas e de desorganização de colágeno (aumento 10x). A2) Detalhe da presença de infiltrado inflamatório denso no tecido (aumento 40x). B) Aspecto geral do fragmento de pele inoculado com veneno incubado com o inibidor 1 (aumento 5x). B1) Detalhe da presença de infiltrado inflamatório e áreas hemorrágicas no tecido (aumento 10x). B2) Detalhe da desorganização de fibras colágenas e áreas hemorrágicas próximas à camada muscular adjacente (aumento 20x). As lâminas foram analisadas e fotografadas em microscópio Leica DM2500 com o auxílio do software Leica QWin Plus Y2.8. 
Figura 30 - Análise histopatológica de fragmentos de pele de coelhos inoculados com veneno de L. laeta na presença dos inibidores 5 e 6
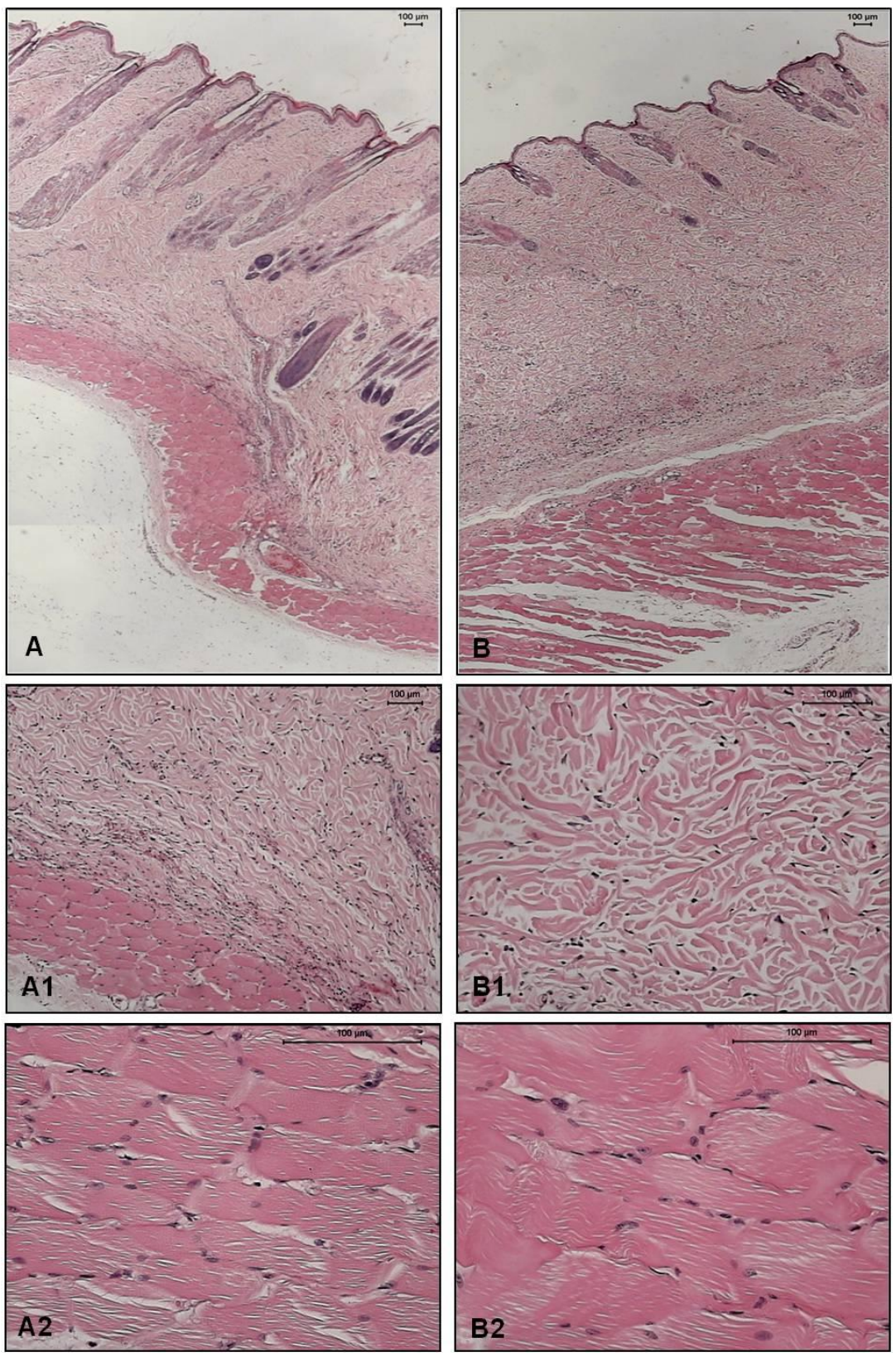

Fragmentos de pele de coelhos inoculados com $5 \mu \mathrm{g}$ de veneno de $L$. laeta presença dos inibidores 5 e 6 na concentração de 3 IC $_{50}(136,08$ e 190,08 $\mu \mathrm{M}$, respectivamente) foram retirados 72 horas após a inoculação e fixados em formol $4 \% \mathrm{pH} \mathrm{7,4.} \mathrm{As} \mathrm{amostras} \mathrm{foram} \mathrm{encaminhadas} \mathrm{para} \mathrm{a} \mathrm{confecção} \mathrm{de} \mathrm{lâminas} \mathrm{histológicas}$ permanentes coradas com Hematoxilina-Eosina. A) Aspecto geral do fragmento de pele inoculado com veneno incubado com o inibidor 5 (aumento 5x). A1) Detalhe da reduzida desorganização de colágeno, ausência de áreas hemorrágicas e infiltrado inflamatório (aumento 10x). A2) Detalhe da camada muscular adjacente íntegra (aumento 40x). B) Aspecto geral do fragmento de pele inoculado com veneno incubado com o inibidor 6 (aumento 5x). B1) Detalhe da reduzida desorganização de colágeno, ausência de áreas hemorrágicas e infiltrado inflamatório (aumento 20x). B2) Detalhe da camada muscular adjacente íntegra (aumento 40x). As lâminas foram analisadas e fotografadas em microscópio Leica DM2500 com o auxílio do software Leica QWin Plus Y2.8. 
Figura 31 - Análise histopatológica de fragmentos de pele de coelhos inoculados com veneno de L. laeta na presença dos inibidores 8 e 10
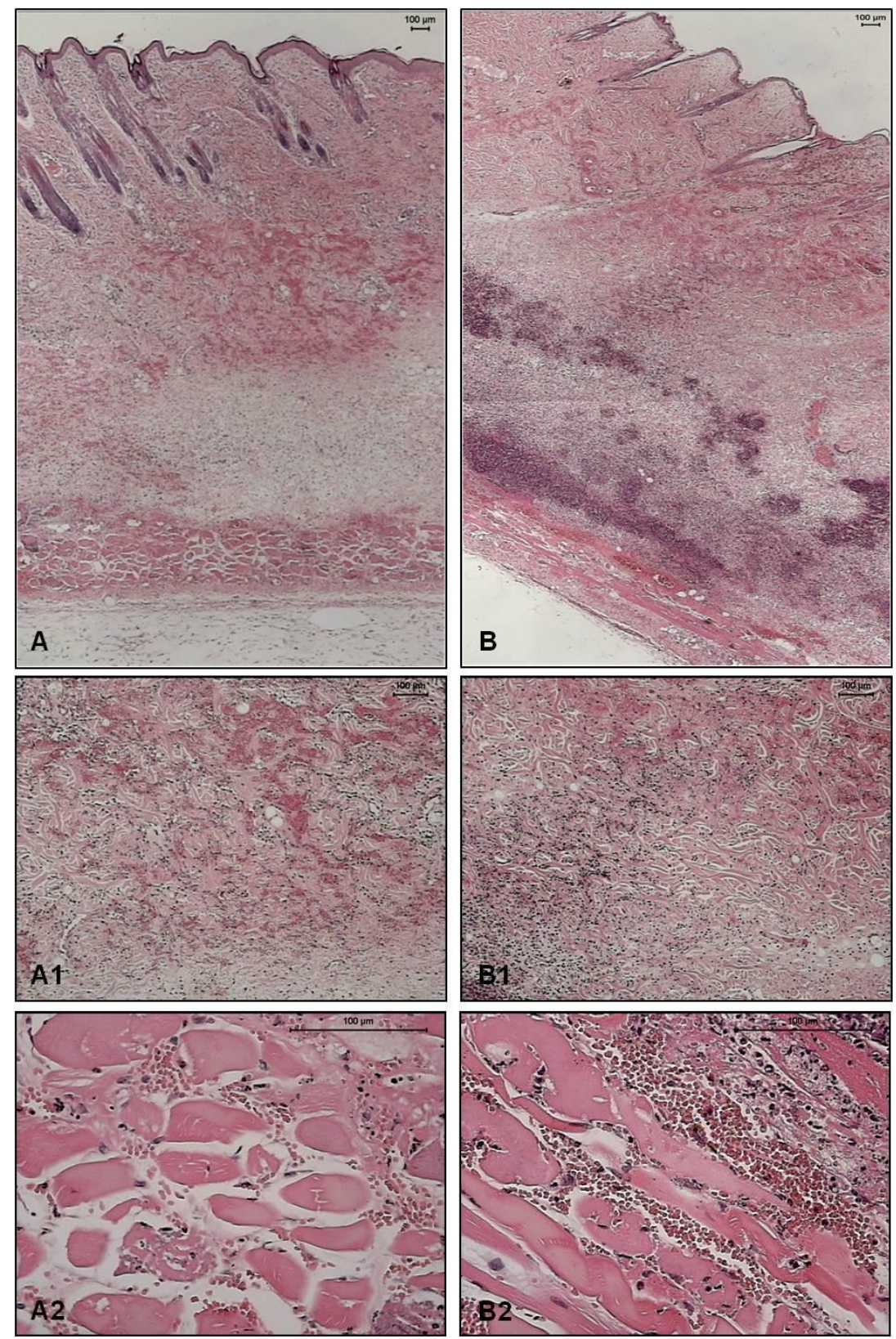

Fragmentos de pele de coelhos inoculados com $5 \mu \mathrm{g}$ de veneno de L. laeta na presença dos inibidores 8 e 10 na concentração de $3 \mathrm{IC}_{50}(220,08$ e 254,55 $\mu \mathrm{M}$, respectivamente) foram retirados 72 horas após a inoculação e fixados em formol $4 \% \mathrm{pH} \mathrm{7,4}$. As amostras foram encaminhadas para a confecção de lâminas histológicas permanentes coradas com Hematoxilina-Eosina. A) Aspecto geral do fragmento de pele inoculado com veneno incubado com o inibidor 8 (aumento 5x). A1) Detalhe de áreas hemorrágicas e de desorganização de colágeno com infiltrado celular (aumento 10x). A2) Detalhe da lesão com áreas hemorrágicas na camada muscular adjacente (aumento 40x). B) Aspecto geral do fragmento de pele inoculado com veneno incubado com o inibidor 10 (aumento 5x). B1) Detalhe da presença de infiltrado inflamatório e áreas hemorrágicas no tecido (aumento 10x). B2) Detalhe da lesão com áreas hemorrágicas e infiltrado celular na camada muscular adjacente (aumento 40x). As lâminas foram analisadas e fotografadas em microscópio Leica DM2500 com o auxílio do software Leica QWin Plus Y2.8. 


\subsection{Novos estudos sobre o mecanismo de ação das SMases D de Loxosceles}

4.9.1 Investigação da participação da via de sinalização intracelular MAPK pERK 1/2 no mecanismo de ação das SMase D

A análise de células HaCat tratadas com meio, veneno ou SMase I por 30 ou 60 minutos, utilizando o kit Titerzime EIA Phospho-ERK1/2, mostrou que tanto o veneno quanto a SMase I foram capazes de ativar esta via de sinalização como demonstrado pela detecção de ERK1/2 fosforilada de maneira significativamente maior do que no tratamento com tampão (Figura 32A). Uma vez que a detecção de ERK1/2 fosforilada em células tratadas com a SMase I por 30 minutos não difere do mesmo tratamento por 60 minutos, o tempo de 30 minutos foi utilizado para avaliar a eficácia dos compostos inibidores sobre a ativação desta via de sinalização. A figura 32B mostra que os compostos 1, 5, 6, 8 e 10 foram capazes de reduzir a indução de ERK1/2 fosforilada pela SMase I. Neste ensaio o PMA (phorbol 12myristate 13-acetate) foi utilizado como controle positivo de ativação da via. 
Figura 32 - Ação da SMase I e veneno de L. laeta sobre a via de sinalização ERK1/2 em queratinócitos

A)
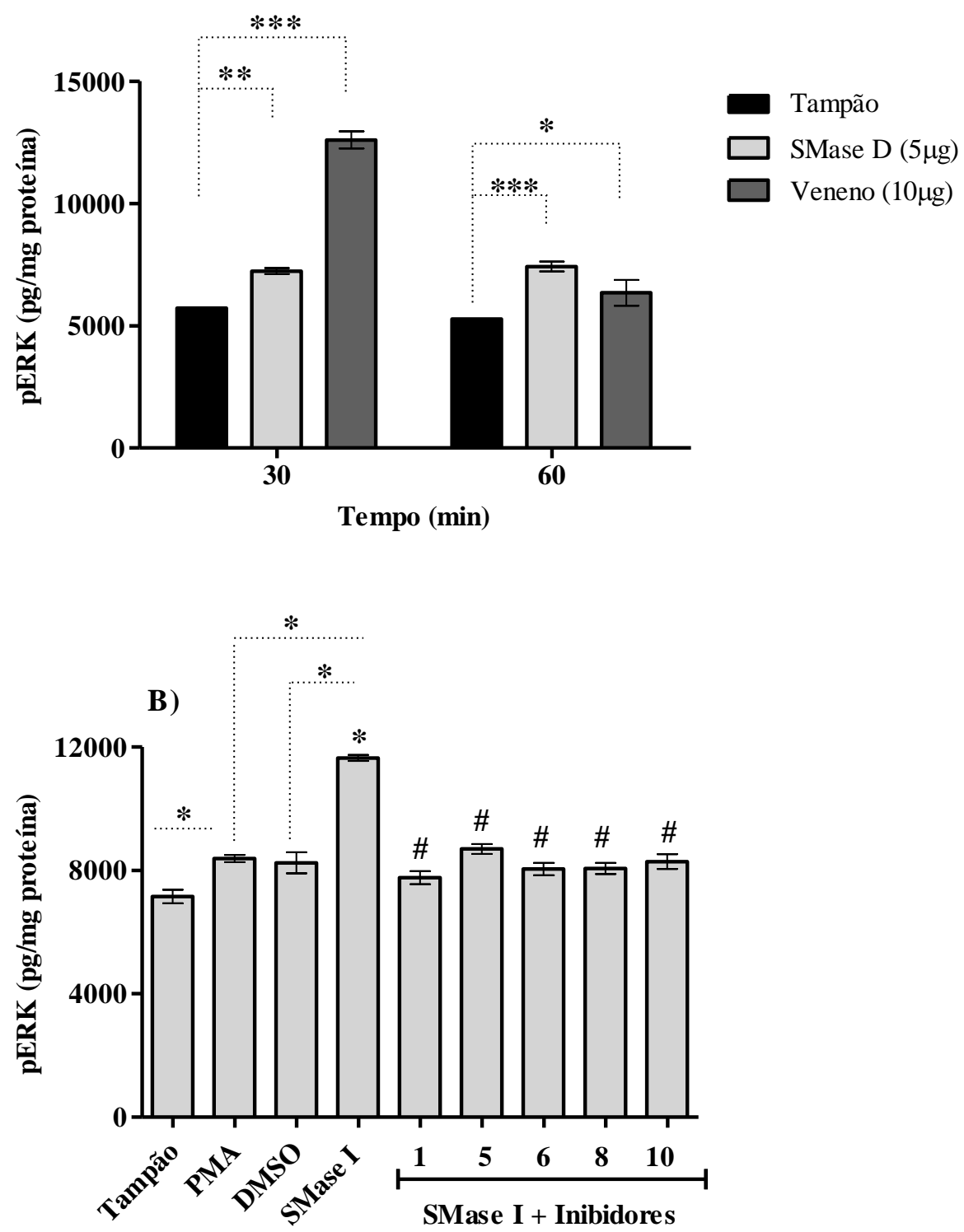

Células HaCat $\left(1 \times 10^{6} / \mathrm{mL}\right)$ foram tratadas com amostras de $5 \mu \mathrm{g}$ de SMase I, $10 \mu \mathrm{g}$ do veneno de L. laeta ou tampão por 30 e 60 minutos e foram analisadas quanto a detecção de ERK1/2 fosforilada utilizando o Kit Titerzime EIA Phospho-ERK1/2. A) Detecção de ERK1/2 fosforilada após tratamento de células HaCat com SMase I, veneno ou tampão por 30 e 60 minutos. B) Ação dos compostos inibidores sobre a detecção de ERK 1/2 induzida pela SMase I, após 30 minutos. Os dados estão representados como média \pm erro padrão de duplicatas representativo de dois experimentos independentes. Analisado estatisticamente por One Way ANOVA e Two Way ANOVA seguido por teste de Tukey HSD. (*) Diferença significativa em relação ao tampão $(p<0,05)$; (\#) Diferença significativa em relação à SMase I $(p<0,05)$. 


\subsubsection{Ação da SMase I na produção de ROS e RNOS por queratinócitos humanos}

A análise da produção de espécies reativas do oxigênio (ROS) mostrou que a SMase I foi capaz de induzir um aumento significativo na produção do radical superóxido em queratinócitos humanos (Figura 33A). No entanto, a produção de peroxinitrito não diferiu nas células tratadas com SMase I e tampão (Figura 33B).

Quanto à investigação da eficácia das moléculas inibidoras sobre a indução do radical superóxido, os resultados mostraram que os compostos 5 e 6 foram capazes de reduzir significativamente a produção deste radical (Figura 33C).

Uma vez que a formação de peroxinitrito decorre da união entre o radical superóxido e óxido nítrico, a produção de $\mathrm{NaNO}_{2}$, um metabólito do $\mathrm{NO}$, foi analisada no sobrenante das culturas de queratinócitos humanos tratados com a SMase I. Os resultados indicam que não há a indução de produção significativa de NO (Figura 33D). 
Figura 33 - Produção de ROS e RNOS por queratinócitos humanos tratados com SMase I

A)

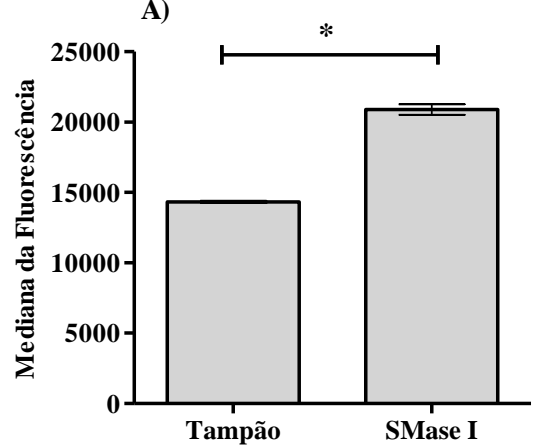

C)

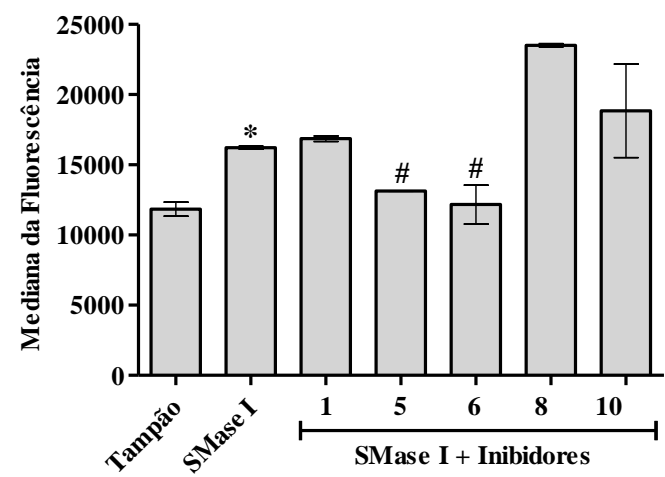

B)

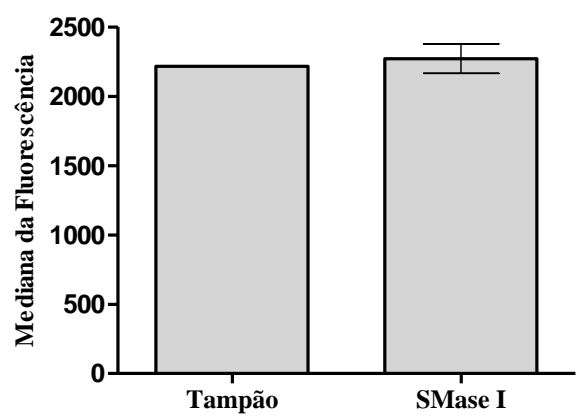

D)

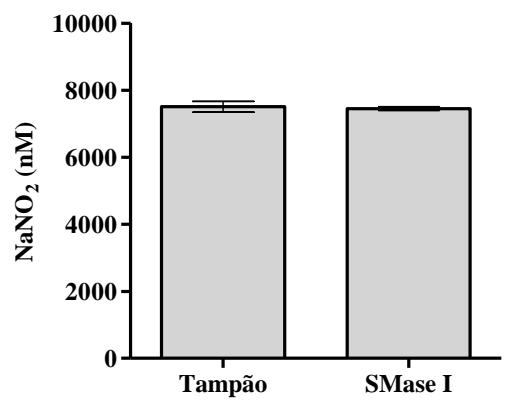

Células HaCat $\left(1 \times 10^{6} / \mathrm{mL}\right)$ foram tratadas com amostras de $5 \mu \mathrm{g}$ de SMase I na presença ou ausência dos inibidores $(40 \mu \mathrm{M})$, ou tampão por duas horas e foram analisadas quanto a presença de superóxido $\left(\mathrm{O}_{2}{ }^{\circ}\right)$ e peroxinitrito $\left(\mathrm{ONOO}^{-}\right)$por citometria de fluxo. A produção de $\mathrm{NaNO}_{2}$ no sobrenadante de cultura de queratinócitos humanos tratados com $5 \mu \mathrm{g}$ de SMase I, por duas horas foi analisada pelo método de Griess com base em uma curva padrão de nitrito de sódio de 500 a 10.000 nM. A) Produção de superóxido por queratinócitos após tratamento com SMase I ou tampão. B) Produção de peroxinitrito por queratinócitos após tratamento com SMase I ou tampão. C) Ação dos inibidores sobre a produção de superóxido induzida pela SMase I. D) Detecção de $\mathrm{NaNO}_{2}$ em sobrenadantes de cultura de queratinócitos humanos após tratamento com a SMase I ou tampão. Os dados estão representados como média \pm erro padrão de duplicatas representativo de dois experimentos independentes. Analisado estatisticamente por teste t Student ou One Way ANOVA seguido por teste de Tukey HSD para o ensaio com os inibidores. (*) Diferença significativa em relação ao meio $(p<0,001)$. 
4.9.3 Investigação do mecanismo de apoptose em queratinócitos humanos induzido pelas SMases D

\subsubsection{Análise da expressão de Fas (CD95) e FasL (CD178)}

Queratinócitos humanos $\left(1 \times 10^{6} / \mathrm{mL}\right)$ tratados por 24 e 72 horas com tampão, $5 \mu \mathrm{g}$ da SMase I ou $10 \mu \mathrm{g}$ do veneno de L. laeta foram analisadas por citometria de fluxo quanto a expressão de CD95 e CD178. Nas condições utilizadas, tanto a SMase I quanto o veneno não foram capazes de induzir a expressão destas moléculas na superfície dos queratinócitos em nenhum dos tempos testados.

\subsubsection{Análise da expressão dos receptores de TNF (CD120a e CD120b)}

A avaliação da expressão dos receptores de TNF na superfície de queratinócitos por citometria de fluxo mostrou que em células sem tratamento apenas o TNF-RI (CD120a) é expresso nestas células (Figura 34A). Além disso, foi possível observar que a expressão deste receptor foi bastante reduzida em células tratadas com a SMase I (Figura 34B).

Avaliando a ação dos inibidores sobre a redução da expressão do TNF-RI em células tratadas com a SMase I, nota-se que apenas o inibidor $n^{\circ} 5$ foi capaz de reverter tal redução (Figura 34C). 
Figura 34 - Ação da SMase I sobre a expressão dos receptores de TNF na superfície de queratinócitos humanos

A)

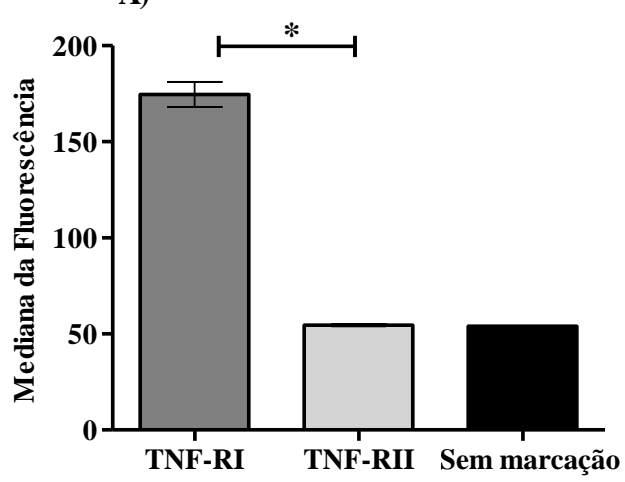

B)

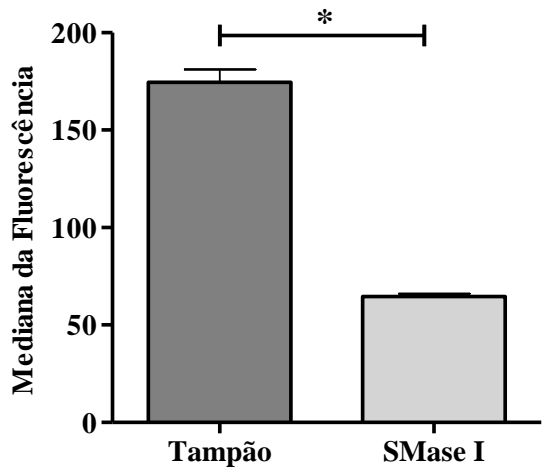

C)

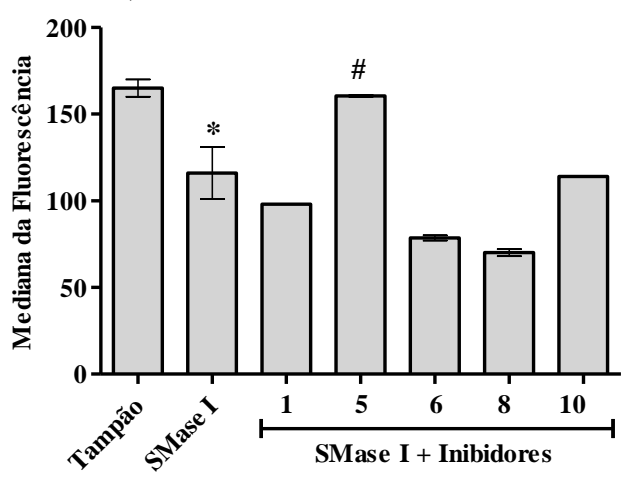

Queratinócitos humanos foram tratados por duas horas com $5 \mu \mathrm{g}$ da SMase I incubada ou não com $40 \mu \mathrm{M}$ de cada inibidor e analisados quanto à expressão dos receptores de TNF por citometria de fluxo. A) Análise da expressão dos receptores de TNF em queratinócitos tratados apenas com tampão. B) Análise da expressão do receptor TNF-RI após tratamento com a SMase I ou tampão. C) Ação dos inibidores sobre a remoção do TNF-RI induzida pela SMase I. Os dados estão representados como média \pm erro padrão de duplicatas representativo de dois experimentos independentes. Analisado estatisticamente por One-Way ANOVA seguido por teste de Tukey HSD ou teste t de Student para a expressão do TNF-RI após tratamento. (*) Diferença significativa em relação ao tampão $(p<0,05)$. (\#) Diferença significativa em relação a SMase I $(p<0,05)$. 
4.9.4 Análise da ação das SMases D sobre a produção de citocinas por queratinócitos humanos

A dosagem das citocinas TNF- $\alpha$, IL-1 $\beta$, IL-6, IL-10 e TGF- $\beta 1$ no sobrenadante de cultura de queratinócitos humanos tratados por 72 horas com SMase I ( $5 \mu \mathrm{g}$ ) na presença ou ausência dos compostos inibidores, foi realizada por ELISA. A figura 32 mostra que a toxina recombinante, foi capaz de induzir a produção de TNF- $\alpha$, TGF- $\beta 1$, IL-6 e IL-1 $\beta$ (Figura 35) pelos queratinócitos de maneira significativamente diferente das células tratadas apenas com meio. Em relação à ação dos inibidores, os compostos 1, 5 e 6 foram capazes de reduzir significativamente a produção de TNF- $\alpha$ e TGF- $\beta 1$ (Figura 35A e D). Em relação à produção de IL-6, apenas o composto 5 se mostrou ativo (Figura 35C) e nenhum dos compostos foi capaz de reduzir a indução de IL-1 $\beta$ (Figura 35B). A citocina IL-10 não foi detectada no sobrenadante das células tratadas com SMase I nas condições testadas. 
Figura 35 - Dosagem de citocinas no sobrenadante de cultura de queratinócitos humanos tratados com SMase I

A)

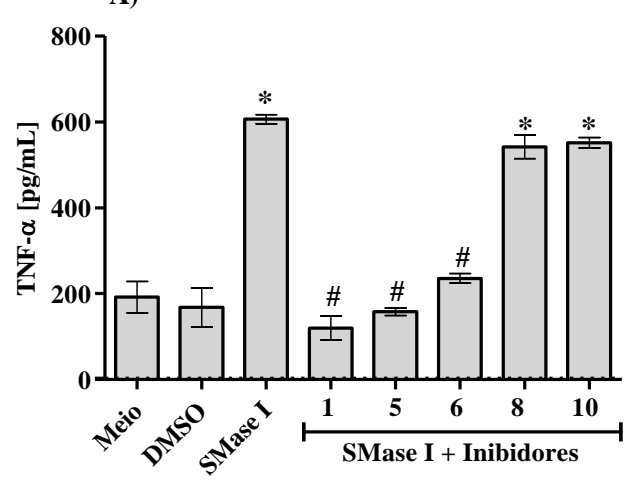

C)

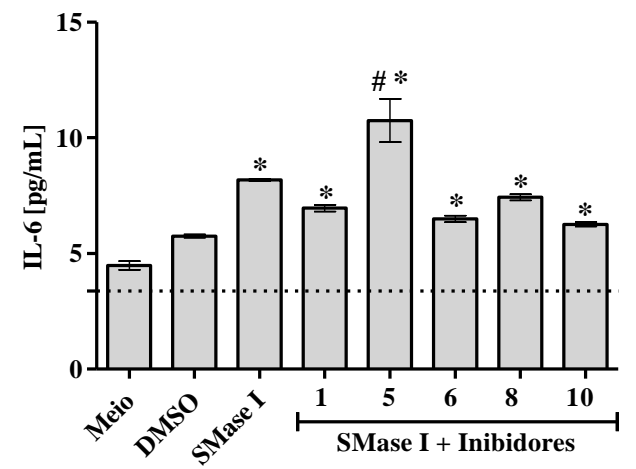

B)

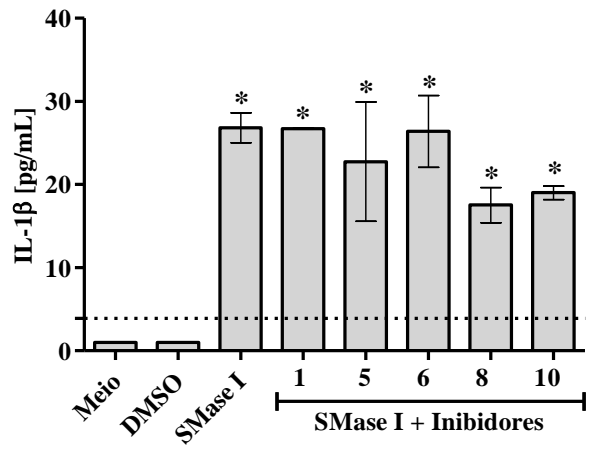

D)

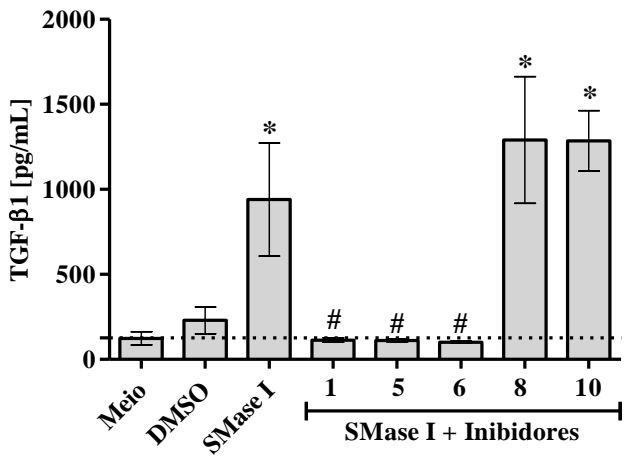

A dosagem de citocinas no sobrenadante de cultura de queratinócitos humanos tratados por 72 horas com SMase I $(5 \mu \mathrm{g})$ na presença ou ausência dos compostos inibidores $(10 \mu \mathrm{M})$, foi realizada por ELISA. Os dados estão representados como média \pm erro padrão da média de duplicatas de quatro experimentos independentes. Analisado estatisticamente por One Way ANOVA seguido pelo pós-teste de Tukey HSD, utilizando o programa GraphPad Prisma 5.1. (*) Diferença significativa em relação ao meio ( $p<0,05)$; (\#) Diferença estatística em relação a SMase I ou veneno $(p<0,05)$. 


\section{DISCUSSÃO}

Nos acidentes com aranhas do gênero Loxosceles duas são as variantes clínicas, i.e., o loxoscelismo cutâneo (LC) e o loxoscelismo cutâneo-visceral (LCV) ou sistêmico. As mais variadas intervenções têm sido propostas como tratamento para o loxoscelismo, no entanto, uma ferramenta terapêutica definitiva e totalmente eficaz ainda não foi estabelecida. Dentre os tratamentos utilizados, medicamentos como Dapsona e Colchicina, conhecidos como Sulfonas, são inibidores da degranulação de células polimorfonucleares e da liberação de mediadores químicos, reduzindo a inflamação local e, assim, a destruição tecidual. No entanto, a literatura mostra uma grande controvérsia nos resultados obtidos com estes medicamentos em humanos e animais experimentais, além do aparecimento de uma ampla gama de efeitos colaterais (revisado por HOGAN; BARBARO; WINKEL, 2004). Debridamento cirúrgico e enxertos de pele foram as primeiras intervenções utilizadas no loxoscelismo cutâneo (AUER; HERSHEY, 1974; HERSHEY; AULENBACHER, 1969). Outras intervenções terapêuticas como o uso de corticosteróides, antibióticos e oxigênio hiperbárico têm sido utilizadas no loxoscelismo (revisado por HOGAN; BARBARO; WINKEL, 2004), além de transfusão de sangue e hemodiálise (RIBEIRO et al., 1993).

No Brasil, o tratamento mais empregado para o loxoscelismo é a soroterapia. Apesar de alguns autores acreditarem que este tratamento reduza os riscos de desenvolvimento do quadro clínico sistêmico com hemólise, coagulação intravascular disseminada, falência renal e outras complicações (PAULI et al., 2006), não existe um consenso quanto à sua eficácia sobre as lesões locais (BRASIL, 2001). Nos casos de maior gravidade, as intervenções terapêuticas atualmente empregadas não têm sido completamente eficientes e, portanto, a melhor caracterização dos mecanismos moleculares de ação do veneno é importante para o estabelecimento de propostas terapêuticas mais eficazes para o loxoscelismo.

Paixão-Cavalcante et al. $(2006,2007)$ demonstraram que a tetraciclina parece ser uma alternativa eficaz no tratamento das lesões cutâneas do loxoscelismo, uma vez que esta induz uma redução significativa na expressão de metaloproteases de matriz extracelular MMP-2 e MMP-9 e, consequentemente, da morte celular por apoptose. De Almeida et al. (2008) demonstraram que um soro produzido a partir de esfingomielinases D recombinantes das espécies L. laeta (SMase I) e L. intermedia (P1 e P2) foi capaz de neutralizar eficientemente as atividades destes venenos e do veneno de L. gaucho, sendo mais eficaz que o soro antiaracnídico, utilizado terapeuticamente no Brasil, que é produzido a partir dos venenos de 
L. gaucho (21,5\%), Phoneutria nigriventer (21,5\%) e Tityus serrulatus (57\%). A eficiência deste soro reforça a ideia de que as SMases D são os principais componentes tóxicos dos venenos de Loxosceles e, portanto, alvos importantes para o desenvolvimento de terapias mais eficazes para o loxoscelismo (TAMBOURGI et al., 2010).

Com base na estrutura da SMase D I de Loxosceles laeta e em estudos de Docking molecular, foram identificados compostos químicos com potencial para interagir com as esfingomielinases e inibir sua atividade tóxica.

A SMase I de Loxosceles laeta foi purificada de extratos de bactérias transformadas com o inserto em vetor pAe, por cromatografia de afinidade, resultando em uma única banda proteica com massa molecular de cerca de $35 \mathrm{kDa}$. A proteína recombinante se mostrou ativa, capaz de hidrolisar os substratos esfingomielina e lisofosfatidilcolina, bem como de induzir morte celular e hemólise, dependente do sistema complemento, como mostrado em estudos anteriores (FERNANDES-PEDROSA et al., 2002; PAIXÃO-CAVALCANTE et al., 2006; TAMBOURGI et al., 1998; VAN MEETEREN et al., 2004). Em todos os ensaios, a SMase D se mostrou mais eficiente que o veneno de L. laeta.

Estudos de inibição mostraram que todos os 14 compostos selecionados por docking molecular foram capazes de interferir, com diferentes intensidades, com a atividade esfingomielinásica. Compostos que induziram inibição superior a 20\%, ou seja, 1, 5, 6, 7, 8, 10, 11, 12 foram escolhidos para dar continuidade ao estudo. A maioria destas moléculas causou inibição dose-dependente.

Com base nas curvas dose-resposta da atividade hidrolítica sobre o substrato esfingomielina foi possível calcular o valor de $\mathrm{IC}_{50}$ para os compostos $1,5,6,8$ e 10 . O composto 5 possui o menor valor de $\operatorname{IC}_{50}(45,36 \pm 1,01 \mu \mathrm{M})$ e, portanto, em relação à inibição da atividade hidrolítica, este pode ser considerado o mais eficaz dos compostos. Tal fato não está de acordo com os resultados dos estudos de Docking realizados para seleção dos inibidores, uma vez que o composto 1 foi o que demonstrou melhor energia de ligação com Goldscore de 99.28, sendo que o score para o composto 5 foi de 89,82 (Tabela 2). No entanto, o $\mathrm{IC}_{50}$ dos compostos 1 e 5 não diferiu estatisticamente, o que pode indicar que a eficiência destes possa ser semelhante em relação à inibição da atividade hidrolítica sobre esfingomielina. $\mathrm{O}$ maior valor de $\mathrm{IC}_{50}$ calculado, denotando menor eficiência dentre os testados, foi o do composto $10(84,85 \pm 1,12 \mu \mathrm{M})$, o qual por sua vez recebeu nos estudos de Docking, o menor valor de Goldscore $(88,18)$ dentre os cinco escolhidos. 
Inibidores de SMases ácidas, alcalinas ou neutras foram analisados em diversos estudos e uma grande variação nos valores de $\mathrm{IC}_{50}$ tem sido descrita (ARENZ, 2010; IMAGAWA et al., 2010; LEE et al., 2011; OKUIDARA et al., 2000; PITSINOS et al., 2003; UCHIDA et al., 1999; WELZENBACH; HOMMEL; WEITZ-SCHMIDT, 2002). Okuidara et al. (2000), em um estudo de screening de produtos naturais em busca de inibidores da SMase ácida, identificaram três compostos provenientes da casca de Garcinia speciosa, com valores de $\mathrm{IC}_{50}$ de 14,1, 19,2 e 10,9 $\mu \mathrm{M}$. Outros inibidores de SMases celulares como o Scyphostatin, produto natural derivado do fungo Dasyscyphus mollissimus, apresentou atividade inibitória sobre as SMases ácidas com valor de IC $_{50}$ de 49,3 $\mu \mathrm{M}$ (PITSINOS et al., 2003); o composto inibidor de SMases neutras, Alutenusin, produzido pelo fungo Penicillium, $\mathrm{IC}_{50}$ de $28 \mu \mathrm{M}$ (UCHIDA et al., 1999), enquanto Imagawa et al. (2010) sintetizaram um inibidor para SMases neutras, com estrutura análoga ao substrato esfingomielina, que pode ser considerado um dos mais potentes inibidores de SMases celulares já identificado, com valor de $\mathrm{IC}_{50}$ de apenas $1,2 \mu \mathrm{M}$.

O IC 50 é uma medida da eficácia de um composto em função da inibição biológica ou bioquímica. Esta medida quantitativa indica o quanto de um determinado medicamento ou outra substância é necessário para inibir um certo processo biológico ou componente de um processo, isto é, uma enzima, um receptor celular, ou microrganismo, pela metade. É comumente usada como uma medida de potência de drogas antagonistas na investigação farmacológica. É uma medida comparável a $\mathrm{EC}_{50}$ de drogas agonistas, no entanto, $\mathrm{IC}_{50}$ não é um indicador direto da afinidade do inibidor, embora os dois possam ser relacionados pelo menos em estudos de agonistas e antagonistas competitivos (CHENG; PRUSOFF, 1973). Portanto, como visto nos estudos acima citados, os compostos inibidores aqui testados também mostraram diferentes valores de $\mathrm{IC}_{50}$ que variaram na faixa de 45 a $85 \mu \mathrm{M}$. Tais valores não são muito distintos daqueles descritos na literatura, sendo que estas variações podem estar relacionadas às diferentes energias de ligação obtidas nos estudos de docking molecular, tipo de estudo de docking, tipo de atividade biológica avaliada e método (CHENG; PRUSOFF, 1973), bem como o mecanismo inibitório de cada composto (LEE et al., 2011).

Entre os inibidores de esfingomielinases celulares têm sido identificados principalmente mecanismos de inibição competitiva e não competitiva. $\mathrm{O}$ análogo do $\mathrm{N}$ palmitoylsphingosine-1-phosphate inibe a SMase neutra de forma não competitva com $K_{i}$ de 1,6 M (YOKOMATSU et al., 2003). Fosfato inorgânico também parece atuar sobre a SMase ácida de maneira não competitiva (TESTAI et al., 2004). Inibidores extraídos de produtos 
naturais como o Alutenusin, um inibidor da SMase neutra extraído do fungo Penicillium, possui $K_{i}$ de $20 \mu \mathrm{M}$ e atua por mecanismo de inibição não competitivo (UCHIDA et al., 1999). De maneira diferente, um inibidor da SMase neutra, análogo de fosfato éster, mostrou um mecanismo de inibição competitiva com $K_{i}$ de 5,2 $\mu \mathrm{M}$ (IMAGAWA et al., 2010) e dois inibidores da SMase neutra 2, o D-lyxo-phytosphingosine e D-arabino-phytosphingosine parecem atuar de maneira competitiva, com valores de $K i$ de 22,5 e $34,2 \mu \mathrm{M}$, respectivamente (LEE et al., 2011).

A análise do mecanismo de inibição, das moléculas aqui estudadas, mostrou que os compostos 5 e 6 exercem sua atividade inibitória sobre a SMase I de maneira incompetitiva com valores de $K_{i}$ de 1,63 e 1,73 $\mu \mathrm{M}$, respectivamente. Também conhecida como anticompetitiva, este tipo de inibição é considerada um caso especial de inibição ocasionalmente observada e, principalmente, com enzimas multisubstratos. Caracteriza-se pelo fato de que o composto inibidor se liga apenas no complexo formado entre a enzima e o substrato e não na enzima livre. Este tipo de inibidor não necessariamente se assemelha ao substrato e presumese que ocasione uma distorção no sítio ativo, tornando assim a enzima cataliticamente inativa sem afetar a ligação do substrato (BERG; TYMOCZKO; STRYER, 2007) e, portanto, presume-se que se ligue numa porção da enzima diferente daquela em que se liga o substrato.

Já o composto 1 demonstrou um comportamento de inibição mista com valor de $K i$ de $1,70 \mu \mathrm{M}$. Tal mecanismo é muito semelhante à inibição não competitiva, ou seja, o composto tem a capacidade de se ligar tanto à enzima livre quanto ao complexo enzima-substrato, podendo interferir tanto na ligação ao substrato, quanto na catálise. No entanto, de maneira diferente da inibição não competitiva, o complexo enzima-substrato-inibidor possui atividade enzimática residual (BERG; TYMOCZKO; STRYER, 2007). Este tipo de inibição pode ser reduzida, mas não sobreposta, aumentando as concentrações de substrato. Embora seja possível para os inibidores de tipo misto ligarem-se ao sítio ativo, este tipo de inibição geralmente resulta de um efeito alostérico onde o inibidor se liga a um local diferente do substrato. A ligação do inibidor a este sítio alostérico muda a conformação da enzima de modo que a afinidade do sítio ativo pelo substrato é reduzida.

A inibição incompetitiva é muito incomun na natureza e uma possível explicação para isso é que a inibição incompetitiva de uma enzima em uma via metabólica pode ter efeitos muito maiores sobre a concentração de intermediários metabólicos que uma inibição competitiva. Portanto, a grande gama de efeitos tóxicos que um inibidor incompetitivo natural pode ter, levou à evolução de enzimas em um mecanismo de seleção contra estruturas que 
possam favorecer este tipo de inibição (CORNISH-BOWDEN, 1986). No entanto, é um tipo de inibição altamente eficiente, já que se liga ao complexo enzima-substrato e estes têm alta afinidade e interagem fortemente (BERG; TYMOCZKO; STRYER, 2007). Assim como os compostos 5 e 6, o inibidor 1 parece se ligar em um sítio diferente daquele em que se liga o substrato. Desta forma, os resultados obtidos indicam que mesmo não sendo as moléculas que receberam os maiores valores de Goldscore nos estudos de docking, os compostos 5 e 6 se mostraram eficazes em modular a atividade da SMase I do veneno de L. laeta em quase todos os aspectos testados e, possivelmente, a capacidade de se ligar ao complexo enzima-substrato, caracterizando uma inibição incompetitiva, contribui para a eficiência destas moléculas. No entanto, no caso do composto 1, mesmo tendo o maior valor de Goldscore gerado nos estudos de docking, a geração do complexo enzima-substrato-inibidor com atividade enzimática residual e a atenuação da atividade inibitória com o aumento da concentração de substrato possivelmente contribuem para a não inibição eficiente da dermonecrose e de outros aspectos estudados.

Os mecanismos de inibição determinados aqui são apenas para a inibição da atividade da SMase I sobre o substrato esfingomielina e não se aplicam ao substrato lisofosfatidilcolina, uma vez que quando uma enzima tem vários substratos, inibidores podem mostrar tipos diferentes de inibição dependendo do substrato considerado. Isto resulta de que o sítio ativo pode conter dois sítios de ligação diferentes, um para cada substrato. Desta forma, um inibidor poderia competir com o substrato A, para o primeiro local de ligação, mas ser um inibidor não competitivo em relação ao substrato B na segunda posição de ligação (SEGEL, 1993).

A principal propriedade analisada neste projeto, para fazer a seleção inicial dos inibidores de SMase D foi a capacidade de hidrolisar esfingomielina, sendo que tal inibição pode se dar talvez por alterações alostéricas ou pela interação com o sítio ativo da enzima. Chen et al. (1999), estudando um inibidor da Estromelisina, proteinase zinco-dependente pertencente à família das MMPs, mostrou que este causa deslocamento do resíduo Tyr223, induzindo alteração conformacional de todo o loop, do resíduo 222 ao 231. Outras modificações conformacionais podem ser induzidas em uma enzima pela ligação do inibidor a sítios diferentes daquele no qual o substrato se liga, fenômeno conhecido como inibição alostérica. Horn e Shoichet (2004) demonstraram que dois inibidores da $\beta$-lactamase ligam-se a sítios crípticos da proteína localizados a $16 \AA$ do sítio ativo; no entanto, as mudanças conformacionais são transmitidas por meio de uma série de movimentos ligados, até o resíduo 
catalítico chave, Arg244, o qual por sua vez adota conformações muito diferentes daquelas da enzima cataliticamente competente.

Segundo De Andrade et al. (2005), modificações estruturais comprometem a habilidade da enzima SMase D em induzir hemólise dependente do sistema complemento e dermonecrose. A isoforma inativa (P3) de SMase D, isolada do veneno de L. intermedia, apresenta um menor conteúdo de $\alpha$-hélices em relação às demais isoformas. Tal diferença estrutural poderia afetar a interação do sítio ativo desta proteína com o substrato, o que explicaria a ausência de atividade, sugerindo uma correlação positiva entre conteúdo de $\alpha$ hélices e a atividade biológica das SMases D de Loxosceles.

Para verificar a interferência destas moléculas junto à estrutura secundária da SMase I, foi realizado um ensaio piloto de dicroísmo circular, no entanto, as propriedades do diluente dos inibidores, o DMSO, mesmo em baixas concentrações interferiram na leitura e nos impediram de realizar este tipo de estudo.

O impedimento espacial interferindo na ligação da enzima com o substrato também é um modo de ação de inibidores de SMases celulares e outras enzimas (LEE et al., 2011) e é outra possibilidade de ação de alguns dos compostos aqui estudados, uma vez que a ligação das SMases D de L. laeta à superfície de eritrócitos foi inibida também pelos compostos $8 \mathrm{e}$ 10, os quais podem estar ocupando espacialmente o sítio de ligação da enzima à membrana celular. Outro resultado aqui apresentado e que nos remete a isso, é a inibição da ligação da toxina à superfície de queratinócitos humanos também pelos compostos 8 e 10 .

Outros inibidores podem fornecer átomos que irão agir como quelantes frente ao íon cataliticamente importante da enzima, como acontece com o inibidor de MMPs, o ácido Hidroxâmico, que fornece dois átomos de oxigênio que quelam o zinco do sítio catalítico numa conformação estável (BROWNER, 1994; SPURLINO et al., 1994; GOWRAVARAM et al., 1995).

A partir dos resultados mostrados, foi possível observar que alguns dos inibidores agem de maneira diferente frente ao veneno e à toxina recombinante, ou seja, inibem a atividade da toxina recombinante, mas não inibem a atividade das SMases D no veneno, o que pode indicar que essas moléculas têm mais de um alvo, ou seja, uma possível interação com alguns outros componentes do veneno, impedindo ou reduzindo a ação específica do composto candidato a inibidor. Isto pode também estar relacionado à presença de diversas isoformas de SMases D no veneno. 
Em contraste à principal propriedade analisada neste trabalho, a grande maioria dos estudos sobre inibidores de SMases neutras (nSMases) celulares, relatados na literatura (ARENZ; GIANNIS, 2000; CLAUS et al., 2005; IMAGAWA et al., 2010; INOUE et al., 2004; NARA et al., 1999a, 1999b; PITSINOS et al., 2003; UCHIDA et al., 1999; UCHIDA et al., 2001; WASCHOLOWSKI; GIANNIS, 2006) avaliou a produção de ceramida, por considerarem que a geração deste esfingolipídio poderia estar envolvida em estados patológicos importantes como inflamação e desordens imunológicas ou neurológicas (NARA et al., 1999a).

As SMases D de Loxosceles também possuem a capacidade de hidrolisar lisofosfatidilcolina (LPC) gerando ácido lisofosfatídico (LPA) (VAN MEETEREN et al., 2004; LEE; LYNCH, 2005), potente mediador lipídico capaz de ativar células endoteliais e leucócitos em eventos inflamatórios (ZHAO; NATARAJAN, 2009), induzir agregação plaquetária, proliferação e diferenciação de diversos tipos celulares, tais como queratinócitos, promover a contração de células musculares lisas, quimiotaxia, entre outros (JALINK; HORDIJK; MOOLENAAR, 1994; MOOLENAAR, 1994, 1995).

van Meeteren et al. (2004) demonstraram que o LPA, gerado por ação das SMases D, se liga a receptores acoplados à proteína $\mathrm{G}$ e é capaz de ativar vias de sinalização como das MAP kinases (ERK 1/2) e induzir modificações de citoesqueleto, evocando respostas biológicas em diversos tipos celulares que podem levar ao desenvolvimento de patologias. Levando em consideração que a hidrólise de LPC e, consequentemente, os níveis de LPA no sangue, podem ser alvos de intervenções terapêuticas no loxoscelismo, testamos os inibidores quanto à capacidade de interferir na atividade da SMase I e do veneno de L. laeta sobre o substrato LPC. Foi possível observar que os inibidores 1, 5, 6, 8, 10 e 11 foram capazes de reduzir a clivagem de LPC pela SMase D enquanto que, sobre a atividade do veneno, somente as moléculas 1, 5 e 8 foram significativamente eficazes. Desta forma, as moléculas em estudo são também promissoras no que diz respeito ao controle da hidrólise do LPC e geração de LPA no loxoscelismo.

$\mathrm{Na}$ análise da ação dos inibidores na atividade hidrolítica sobre o substrato LPC, foi também possível observar a diferença na ação dos compostos candidatos a inibidores frente ao veneno e à toxina recombinante, o que mais uma vez pode indicar algum tipo de interação entre componentes do veneno e as moléculas inibidoras, além da presença de muitas isoformas da enzima no veneno. 
Moléculas com capacidade de interferir no ciclo da esfingomielina/ceramida têm emergido como alvos altamente interessantes para o desenvolvimento de novas drogas antiapoptóticas (CLAUS et al., 2000; DEIGNER et al., 2001), anti-neurodegenerativas (DEIGNER; HABERKORN; KINSCHERF, 2000) e anti-inflamatórias (CLAUS et al., 2005). Assim, dois destes inibidores, Gentamicina, reconhecido por sua ampla atividade antibiótica e pela capacidade de inibir SMases em fibroblastos (ROLAIN et al., 2003) e Monensina, um poliéter, antibiótico e ionóforo empregado em estudos de malária (GUMILA et al., 1997), controle de coccidiose (CHAPMAN; JEFFERS; WILLIAMS, 2010), mas também descrito como um redutor da atividade esfingomielinásica, foram testados. Os dois compostos não foram capazes de alterar a atividade das SMases D de L. laeta nas três concentrações testadas. Tal incapacidade dos inibidores de SMases celulares em agir sobre as enzimas de Loxosceles pode estar associada à não relação estrutural das SMases D de aranhas Loxosceles e as SMases endógenas humanas.

O mecanismo de hemólise dependente do sistema complemento, operante no loxoscelismo sistêmico, envolve a ativação de metaloproteinases de membrana, após a ligação das SMases D e clivagem da esfingomielina na superfície de eritrócitos, tornando as células susceptíveis a ação lítica do sistema complemento autólogo (TAMBOURGI et al., 1995, 2000). Na superfície de eritrócitos estão expostas as porções ricas em ácido siálico das glicoforinas, para as quais já foi descrita a sua ação inibitória sobre o sistema complemento (BRAUCH; ROELCKE; ROTHE, 1983; OKADA et al, 1982; TANNER, 1993). Tambourgi et al. (2000) mostraram que o veneno de Loxosceles e as SMases D induzem a clivagem das glicoforinas A, B e C da superfície dos eritrócitos humanos, com remoção das porções extracelulares ricas em ácido siálico, permitindo assim a ativação da via alternativa do complemento, com conseqüente hemólise (TAMBOURGI et al., 2000, 2002, 2004, 2007).

A avaliação da eficácia dos compostos inibidores sobre o desenvolvimento da hemólise não pôde ser realizada pelo mesmo método utilizado para determinar tal atividade para o veneno e a toxina recombinante, pois o diluente dos inibidores, DMSO, em concentrações sublíticas, interfere na reação induzindo em eritrócitos um aumento em seu volume crítico, levando a mudanças conformacionais e interação em propriedades físicoquímicas da membrana celular, o que culmina numa proteção da célula contra a lise osmótica (BRUIJNE; STEVENINCK, 1972, 1974). E de fato, tal proteção induzida pelo DMSO foi observada em nossos experimentos iniciais (dados não mostrados). 
Desta forma, como a clivagem das glicoforinas, pela ação indireta das SMases D de Loxosceles sobre a superfície de eritrócitos, é um evento crucial para o desenvolvimento da hemólise (TAMBOURGI et al., 2000), avaliamos a capacidade dos compostos inibidores em restringir tanto a ligação das SMases D presentes no veneno, bem como de inibir a clivagem de glicoforina C. Desta forma, foi possível observar que os inibidores 1, 5, 6, 8 e 10 foram capazes de reduzir tanto a ligação das SMases D como a remoção de GPC dos eritrócitos. A redução da ligação das SMases D à superfície celular, pode ser devida à interação direta das moléculas inibitórias com o sítio de ligação da enzima à membrana, no caso dos compostos 8 e 10, ou modificação alostérica da SMase D, após ligação dos inibidores, o que impede a ligação ou a torna instável, fazendo com que se desligue com facilidade. Tal fato possivelmente acontece com os inibidores 1, 5 e 6, como mostrado pelo mecanismo de inibição exercido. Portanto, impedindo ou reduzindo a ligação da SMase D à célula, tal enzima não promoverá a clivagem da esfingomielina e, consequentemente, a ativação das metaloproteinases de membrana e a remoção das glicoforinas não ocorrerão, inibindo, assim, a atividade hemolítica da toxina, importante para o desenvolvimento do loxoscelismo sistêmico. Neste sentido, análises estatísticas mostraram que existe uma correlação negativa significativa, ou seja, inversa, entre a ligação da toxina à membrana e a expressão de glicoforina $\mathrm{C}$ na superfície, portanto, a inibição da ligação da toxina é relevante para a redução da atividade da molécula sobre os eritrócitos.

Em termos de loxoscelismo sistêmico, além da hemólise, em modelos animais é importante verificar a eficácia dos compostos candidatos a inibidores sobre a atividade letal do veneno. Tambourgi et al. (1998), utilizando diferentes linhagens de camundongos determinaram a $\mathrm{DL}_{50}$ do veneno de $L$. intermedia e demonstraram que a fração denominada F35 contendo as SMases D também possuía atividade letal, indicando que a SMase D, além da hemólise e dermonecrose também era capaz de induzir morte. Portanto, a inibição das SMases poderia ser também importante na letalidade. No presente estudo, a DL 50 do veneno de L. laeta foi determinada como 7,03 $\mu \mathrm{g} /$ animal e utilizando amostras de veneno equivalentes a duas $\mathrm{DL}_{50}$ tratadas ou não com os inibidores 1,5 e 6 , em concentrações equivalentes a $3 \mathrm{IC}_{50}$, a eficácia dos compostos foi avaliada. Os animais foram acompanhados até 72 horas, mas, no entanto, nenhum dos compostos testados foi capaz de evitar a morte induzida pelo veneno de L. laeta. Tal resultado pode ser devido ao uso de quantidades inadequadas de inibidores para a total neutralização das várias isoformas de SMases D do veneno. 
No que diz respeito ao loxoscelismo cutâneo, Van Den Berg et al. (2002) demonstraram a ativação de metaloproteinases de membrana da família das Adamlisinas, por ação indireta do veneno de Loxosceles/SMases D em células nucleadas. Tais metaloproteases são capazes de clivar moléculas como MCP e MHCI na superfície destas células. Mais tarde, Tambourgi et al. (2005) observaram um aumento da expressão de MMP-2 e 9 na pele de coelhos inoculados com veneno de Loxosceles e em queratinócitos humanos da linhagem HaCat tratados com o veneno ou esfingomielinases recombinantes, e este aumento foi relacionado com a morte destas células por apoptose (PAIXÃO-CAVALCANTE et al., 2006). Neste estudo, ainda, os autores observaram também a remoção de $\beta 2$-microglobulina e EGFR da superfície destas células, pela ação indireta das SMases D. Estes dados revelam que os mecanismos do loxoscelismo cutâneo incluem a ligação das SMases D de Loxosceles aos queratinócitos e indução de morte celular que envolve dois mecanismos, a expressão/secreção de MMPs e a ativação de metaloproteases da família das adamlisinas que, consequentemente, promovem a clivagem de moléculas da superfície destas células.

Corroborando os dados obtidos por Paixão-Cavalcante et al. (2006), tanto o veneno de L. laeta, quanto à SMase I foram capazes de induzir morte de queratinócitos da linhagem HaCat. Quando as células foram tratadas com o veneno/toxina na presença dos inibidores por 72 horas, foi possível observar que os inibidores 1, 5 e 6 foram eficazes em reduzir a morte celular induzida pelo veneno/toxina. No entanto, ao avaliarmos a capacidade dos inibidores em reduzir/inibir a ligação das SMases D à superfície do queratinócito, os compostos 5, 6, 8 e 10 foram capazes de reduzir significativamente esta ligação. Em relação ao composto 1, o qual reduz a morte celular, mas não a ligação da toxina na superfície das células, tal discrepância pode ser devido ao uso de concentrações diferentes do inibidor nos dois aspectos avaliados e também deve-se levar em conta o mecanismo de inibição mista exercido por este composto, onde tal mecanismo pode interferir ou não com a ligação da toxina ao substrato. Desta forma, por impedirem a ligação da toxina à célula, estes compostos reduziriam a ativação das metaloproteases de membrana, evitando a clivagem e remoção de moléculas da superfície e, assim, interferindo em pelo menos um dos mecanismos envolvidos no desenvolvimento do loxoscelismo cutâneo. E assim como na membrana dos eritrócitos, a ligação da toxina à superfície de queratinócitos está correlacionada inversamente com a viabilidade celular.

Estudos têm mostrado que as metaloproteinases de matriz, como a MMP-9, são importantes fatores para a resolução de lesões. Níveis aumentados desta molécula têm sido 
encontrados em muitos tipos de lesões cutâneas crônicas (TRENGOVE; LANGTON; STACEY, 1999). A síntese, ativação e atividade da MMP-9 é, em parte, regulada pela produção de TNF- $\alpha$ (HAN et al., 2001; HAN; NIEN; GARNER, 2002) e a persistência da MMP-9, em ambientes inflamatórios, impede que os queratinócitos migrem para a membrana basal recém-sintetizada, dificultando assim a reepitelização e cicatrização das lesões (REISS et al., 2010). Outras citocinas como TGF- $\beta 1$ também estão envolvidas na modulação da secreção, atividade e associação de MMP-9 na membrana, como mostrado por Festuccia et al. (1995, 2000) em células de câncer de próstata. Outros autores demonstraram que a expressão elevada de MMP-9 pode comprometer a angiogênese (COLNOT et al., 2003; LINDSEY et al., 2006; ULRICH et al., 2005). Assim, chamadas de colagenases tipo IV, a MMP-2 e a MMP-9 estão envolvidas no remodelamento da membrana basal, regulação da migração e proliferação celular durante doenças como câncer e reparo de lesões necróticas (BIRKEDALHANSEN et al., 1993). Uma vez que MMP-2 e 9 são importantes para o reparo das lesões cutâneas e, como observado por Tambourgi et al. (2005) e Paixão-Cavalcante et al. (2006), estão envolvidas no desenvolvimento do loxoscelismo cutâneo, investigamos a ação dos inibidores de SMases sobre a produção de MMPs por queratinócitos. Os resultados aqui apresentados mostram que o veneno de L. laeta foi capaz de induzir aumento significativo de MMP-2 e 9. O tratamento com os inibidores 1, 5, 6, 8 e 10 foi capaz de reduzir o aumento de MMP-2 induzido pelo veneno; no entanto, somente os compostos 1, 5 e 6 foram capazes de inibir o aumento de MMP-9 induzido pelo veneno. Desta forma, os compostos 1, 5 e 6 parecem ser promissores no que diz respeito aos mecanismos de desenvolvimento do loxoscelismo cutâneo.

No loxoscelismo cutâneo há, na maioria dos acidentes, a formação de uma úlcera crônica com extensa destruição tecidual que pode levar muitos meses para cicatrizar (ATKINS et al., 1958; WASSERMAN; ANDERSON, 1983-1984). Alterações histopatológicas semelhantes têm sido observadas em animais experimentalmente envenenados e humanos acometidos pela picada da aranha (MACKINNON; WITKIND, 1953; PIZZI, 1957). Em um modelo animal para o loxoscelismo cutâneo, desenvolvido em coelhos, o veneno de Loxosceles e a SMase D induziram a formação de uma lesão típica com edema, eritema, aumento da temperatura no local da inoculação e dentro de 24 horas já foi possível observar a dermonecrose (PAIXÃO-CAVALCANTE et al., 2007; TAMBOURGI et al., 2005). Da mesma forma, no presente estudo, a inoculação de $5 \mu \mathrm{g}$ de veneno de L. laeta no dorso de coelhos, produziu uma lesão semelhante àquela descrita anteriormente e, através 
da medida destas lesões na presença ou ausência dos inibidores, a eficácia destes compostos foi avaliada. No entanto, a avaliação foi inicialmente dificultada pelo uso do DMSO como diluente dos inibidores, uma vez que este composto também é dotado de propriedades analgésicas, anti-inflamatórias, entre outras, e é empregado no auxílio ao tratamento de várias lesões do sistema nervoso, queimaduras, enxertos de pele em animais e úlceras necróticas em camundongos (DORR et al., 1986; STURION et al., 2005). Para contornar esta dificuldade os compostos inibidores foram preparados numa concentração alta em DMSO e somente depois de completamente dissolvidos foram então diluídos com salina apirogênica para as concentrações a serem utilizadas, de modo que a maior porcentagem de DMSO presente nas misturas foi de no máximo $1 \%$. O controle positivo de lesão (veneno na ausência dos inibidores) recebeu na mistura a mesma proporção de DMSO que as soluções dos inibidores.

Acompanhando por 72 horas as lesões desenvolvidas nos coelhos, foi possível observar que apenas os compostos 5 e 6 foram capazes de reduzir significativamente a lesão e sua progressão. Os demais compostos, apesar de terem sido positivos para algumas outras atividades, não foram eficazes neste ensaio e isto pode ser devido à complexidade do sistema in vivo, com a interferência de outros tipos celulares e moléculas. Os ensaios de dose/resposta mostraram que o composto 5 foi mais ativo do que o 6 , reduzindo a lesão já na dose de um $\mathrm{IC}_{50}(45,36 \mu \mathrm{M})$, enquanto que resultados positivos só foram obtidos, com o composto 6 , com $3 \mathrm{IC}_{50}(190,08 \mu \mathrm{M})$.

Como mencionado por Atkins et al. (1958), Mackinnon e Witkind, (1953), Pizzi, (1957), Tambourgi et al. (2005) e Wasserman e Anderson, (1983-1984) no loxoscelismo cutâneo ocorre a formação de uma úlcera crônica e análises histopatológicas mostraram a presença de um denso infiltrado polimorfonuclear, no entanto, tratamentos com o objetivo de reduzir o infiltrado PMN induzem muitos efeitos colaterais e, em alguns casos, podem aumentar a lesão tecidual (WILSON; HAGOOD; PRATHER, 2005).

Corroborando os estudos de Tambourgi et al. (2005), a análise histopatológica de secções de pele de coelhos inoculados com $5 \mu \mathrm{g}$ do veneno de L. laeta realizadas neste estudo, mostrou desorganização das fibras colágenas na derme, infiltrado inflamatório denso, áreas hemorrágicas e lesões na camada muscular adjacente. No entanto, como mostrado anteriormente, a incubação do veneno com os inibidores 5 e 6 reduz a lesão dermonecrótica e por sua vez, foi possível observar que a desorganização das fibras colágenas e infiltrado inflamatório foram reduzidos. As áreas hemorrágicas, e lesões da camada muscular eram ausentes. 
Estudos sugerem que há uma dependência do infiltrado PMN para o desenvolvimento da lesão, uma vez que foi demonstrado que em animais depletados de sistema complemento, o influxo de neutrófilos era diminuído e a lesão dermonecrótica reduzida; no entanto, dissociação das fibras colágenas, degeneração de fibras musculares e hemorragia ainda persistiam na derme (TAMBOURGI et al., 2005). Outro estudo mais antigo havia demonstrado que a depleção temporária de PMN, reduz a hemorragia, edema e necrose induzidos pelo veneno de L. reclusa, até que o pool de neutrófilos seja restabelecido (SMITH; MICKS, 1970). Considerando estes dois estudos, o infiltrado PMN parece ser apenas em parte recrutado pela ativação indireta do sistema complemento e segundo Patel et al. (1994), seria também recrutado de forma desregulada em decorrência de um dano vascular com consequente sequestro e ativação de neutrófilos que passam pelas células endoteliais lesadas. Além disso, a secreção de citocinas como IL-1, IL-6, IL-8, TNF- $\alpha$ e quimiocinas por fibroblastos ou queratinócitos poderia também induzir o recrutamento (MÁLAQUE; SANTOS; ANDRADE, 1999; VAN MEETEREN, STORTELERS, MOOLENAAR, 2007). Com base nos resultados aqui apresentados, é possível sugerir que a ação dos inibidores 5 e 6 sobre a SMase D em queratinócitos inibindo a ligação da toxina à membrana, a consequente perda da viabilidade celular, a secreção de MMP-2 e 9, bem como a secreção de citocinas como TNF- $\alpha$, contribua de forma significativa para a redução do recrutamento de células inflamatórias e consequentemente da lesão cutânea, podendo ser desta forma, considerados eficazes modelos para o desenvolvimento de terapias para o loxoscelismo cutâneo, bem como ferramentas úteis para uma melhor compreensão dos mecanismos envolvidos.

O conhecimento de novos mecanismos de ação do veneno no desenvolvimento do loxoscelismo é tão importante quanto à busca de novas terapias, portanto, este estudo pretendeu também contribuir para a melhor elucidação deste complexo e multifatorial processo patogênico que é o envenenamento por aranhas Loxosceles. Para tal, usando queratinócitos humanos como modelo de estudo, investigamos aspectos como ativação celular pelo veneno/toxina, via de sinalização intracelular, produção de mediadores como ROS e RNOS, além do mecanismo de apoptose que ocorre em queratinócitos em decorrência da ação do veneno.

Uma grande variedade de fatores de crescimento, citocinas e hormônios regulam processos de reparação na pele (Revisado por SCHÄFER; WERNER, 2007; WERNER; GROSE, 2003). Estudos recentes têm mostrado que NO e ROS são reguladores chave deste processo (SEM; ROY, 2008; WLASCHEK; SCHARFFETTER-KOCHANEK, 2005). ROS 
são cruciais para a defesa contra patógenos invasores (CLARK, 1996) e, baixos níveis são também essenciais mediadores da sinalização intracelular (D’AUTREAUX; TOLEDANO, 2007). Neste contexto, papéis positivos para os ROS nos processos de reparação de feridas têm sido recentemente revistos (SEM; ROY, 2008), no entanto, excessivas quantidades são deletérias devido à sua alta reatividade e estes produtos por si só podem iniciar o dano celular e a apoptose (TYRREL, 1995). Os principais efeitos dos ROS nas células epidermais residem em inibir a proliferação celular, o que pode resultar em dano biológico macromolecular, apoptose, senescencia e necrose (GU et al., 2010; SARAN; MICHEL; BORS, 1998). ROS e RNOS podem utilizar três principais vias de sinalização que resultam em danos ao DNA, proteínas e lipídios. Peroxidação lipídica desencadeia a cascata do ácido araquidônico, com a produção de eicosanóides. Enquanto radicais livres induzem danos ao DNA diretamente, os subprodutos da via do ácido araquidônico, tais como o malondialdeído (MDA) e 4hydroxynonenol (4-HNE) também são agentes que contribuem para tal dano. Os radicais livres podem também modificar sistemas enzimáticos envolvidos no reparo do DNA, alterar a sinalização de morte celular por modificar caspases e também modular a sobrevivência celular através de vias reguladas por moléculas essenciais como JNK e p38 MAPK (revisto em ASLAM; CORT; YUCEL, 2008; ROBERTS et al., 2009a, b).

Os ROS incluem principalmente oxigênio molecular $\left(\mathrm{O}_{2}\right)$, ânion superóxido $\left(\mathrm{O}_{2}{ }^{-}\right)$, peróxido de hidrogênio $\left(\mathrm{H}_{2} \mathrm{O}_{2}\right)$, radicais hidroxila $(\mathrm{OH})$ e ácido hipocloroso $(\mathrm{HOCl})$; os RNOS incluem principalmente o peroxinitrito $\left(\mathrm{ONOO}^{-}\right)$e em modelos de reparo de feridas cutâneas, estudos têm mostrado que baixos níveis de ROS são produzidos em feridas de cicatrização normal e que estes são importantes para o processo de reparo (ROY et al., 2006; OJHA et al., 2008). Em contrapartida, existem evidências de stress oxidativo em úlceras crônicas, o que possivelmente resulta da persistência de um forte infiltrado inflamatório (GUPTA; SINGH; RAGHUBIR, 2002; MOSELEY et al., 2004; WLASCHEK; SCHARFFETTER-KOCHANEK, 2005; YEOH-ELLERTON; STACEY, 2003). O acúmulo de peroxinitrito, molécula agressiva, no processo de reparo da pele atrasa o fechamento da ferida e ocasiona hemorragia no tecido de granulação formado durante o processo de reepitelização, por ocasionar danos às células endoteliais (KUMIN et al., 2006, 2007; MUNZ et al., 1997; WANG et al., 2003).

Sabendo que a geração de ROS e RNOS em queratinócitos pode ser um fator envolvido na morte destas células induzida pela SMase D dos venenos de Loxosceles, foi investigada a produção de ânions superóxido e de peroxinitrito pelas células tratadas por duas 
horas com a toxina. Os resultados mostraram que a SMase I foi capaz de induzir um aumento significativo na produção de superóxido. Desta forma, sabendo que o ânion superóxido $\left(\mathrm{O}_{2}^{-}\right)$ é rapidamente dismutado em peróxido de hidrogênio $\left(\mathrm{H}_{2} \mathrm{O}_{2}\right)$, o qual pode causar danos direta e indiretamente devido à produção de radicais hidroxila $\left(\mathrm{OH}^{\cdot}\right)$ altamente agressivos (CERUTTI; TRUMP, 1991; SIES, 1991), é possível sugerir que a geração de radicais como o superóxido em queratinócitos pela ação da SMase D pode ser fator importante no dano celular do loxoscelismo cutâneo. Os compostos inibidores 5 e 6 foram capazes de reduzir a indução de superóxido pela SMase I em queratinócitos.

Já em relação ao peroxinitrito, este não diferiu significativamente das células tratadas com tampão. Uma vez que o peroxinitrito é a união do ânion superóxido com o NO, foi investigada também a produção de NO e esta também não diferiu nas células tratadas com tampão. No entanto, mesmo que a SMase I não tenha se mostrado capaz de induzir a produção de peroxinitrito nos queratinócitos, sua participação no mecanismo da lesão cutânea do loxoscelismo não pode ser excluída, uma vez que pode ser produzida por outros tipos celulares que não os queratinócitos.

Estudos mostram que o stress oxidativo é capaz de induzir a ativação da via das MAPKs (GUPTA; ROSENBERGER; BOWDEN, 1999). Sua habilidade de ativar ERK1/2 parece ser pleiotrópica e induzida por ROS e RNOS em diversos tipos celulares, sendo já reportado em cardiomiócitos (XIAO et al., 2002), hepatócitos (CONDE DE LA ROSA et al., 2006), linfócitos T (GRIFFTH; ZHANG; WANGE, 1998), fibroblastos (KIM; HAN; CHUNG, 2001) e células epiteliais (BUDER-HOFFAMANN et al., 2001), além de células endoteliais (USATYUK et al., 2003), células musculares lisas (BLANC; PANDEY; SRIVASTAVA, 2003) e células pleurais (JIMENEZ et al., 1997; USATYUK et al., 2003). A ativação desta via por ROS pode ser dar tanto pela ativação de receptores como o EGFR, por exemplo, quanto diretamente pela ativação de Src quinases e consequentemente ativando Ras e induzindo o downstream da cascata de sinalização (HUANG et al., 2001; KELICEN et al., 2002; LEE; ESSELMAN, 2002). Nossos resultados mostraram que a SMase I é capaz de ativar a via de sinalização MAPK ERK1/2 em queratinócitos e, desta forma, é possível pensar na hipótese de que a ativação desta via seja também, em consequencia da geração de ROS pela SMase nestas células.

Sabendo que a proliferação celular é de suma importância para a reparação cutânea, uma das principais vias de sinalização relacionada, em queratinócitos, é a das MAPKs, entre as quais, a ERK1/2 tem sido implicada na regulação de processos como crescimento celular, 
diferenciação e apoptose. Diferentes estímulos como fatores de crescimento, citocinas, infecções virais, ligantes de receptores acoplados à proteína $\mathrm{G}$, entre outros, são capazes de ativar esta via de sinalização (JOHNSON; LAPADAT, 2002). Estudos mostraram que TNF- $\alpha$ é capaz de ativar a via das MAPK, mais especificamente ERK1/2 em queratinócitos por dois caminhos paralelos, um dependente de EGFR e outro independente (ZIV et al., 2008).

Além de processos mitóticos, estas quinases têm sido associadas, também, com estresse químico/osmótico (DERIJARD et al., 1994; KYRIASKIS et al., 1994), diferenciação celular (QUI; GREEN, 1992) e migração (HARTMANN et al., 1994; KLEMKE et al., 1994). Estudos têm mostrado que fatores de crescimento estimulam a migração de queratinócitos induzida por integrinas, via ativação de Ras/MAPK (HARTMANN et al., 1994; KLEMKE et al., 1994), no entanto outros trabalhos revelam que uma série de proteases de matriz extracelular é produzida neste processo, incluindo a MMP-9 (BOYD, 1996; JENSON; RODECK, 1993; LYONS et al., 1993; McCAWLEY; OBRIEN; HUDSON, 1998), sendo as vias ERK, JNK e p38 reportadas como importantes na expressão gênica da MMP-9 (GUM et al., 1997; HIMELSTEIN et al., 1997; LYONS et al., 1993; SIMON; GOEPFERT; BOYD, 1998). Além disso, várias outras evidências suportam a hipótese de que a ativação de MAPK contribui para a indução da expressão de MMP-9 ativada por sinais de estresse (BAHARSHANY; RAVID; KOREN, 2010; HOLVOET et al., 2003; LEE et al., 2010;) e achados recentes mostram que altos níveis de MMP-9 podem indicar inflamação e baixa cicatrização (RAYMENT; UPTON; SHOOTER, 2008).

Desta forma, sabendo-se que a SMase D e o veneno de Loxosceles são capazes de induzir um aumento da expressão de MMPs, como demonstrado por Tambourgi et al. (2005) e Paixão-Cavalcante et al. (2006) e que esta via pode ser induzida de maneira independente do EGFR (ZIV et al., 2008), o qual é clivado da superfície da célula pela ação indireta da SMase D, investigou-se a participação da via de sinalização MAPK ERK1/2 na ação do veneno/toxina em queratinócitos. Foi possível observar que 30 e 60 minutos após o tratamento das células com veneno ou toxina, a presença de ERK1/2 fosforilada de maneira significativamente diferente dos controles negativo e positivo. $\mathrm{O}$ uso dos inibidores mostrou que todos os compostos foram capazes de interferir com a ativação induzida pela SMase D. Portanto, este resultado sugere que há a participação da via das MAPKs, mais especificamente ERK1/2 na ação da SMase D de Loxosceles sobre queratinócitos e que esta pode talvez estar relacionada ao aumento da expressão de MMPs. A ativação desta via de sinalização pelas SMases D de Loxosceles já foi demonstrada em células B103 de neuroblastoma de rato. Esta 
ativação, no entanto, foi associada à hidrólise do LPC ligado à albumina com consequente geração de LPA, o qual age sobre um receptor específico na célula e induz a via de sinalização (VAN MEETEREN et al., 2004).

Na lesão cutânea induzida pelo veneno de Loxosceles, a morte celular é um evento crucial. Paixão-Cavalcante et al. (2006) demonstraram que queratinócitos humanos tratados com veneno ou as SMases D sofriam morte celular por apoptose, como mostrado pela ligação de anexina-V na superfície da célula e pela fragmentação de DNA. A apoptose pode ser iniciada pela via extrínseca através da ligação de ligantes de morte, TNF- $\alpha$, FasL e TRAIL, aos seus receptores na superfície da célula (Fas, TNF-R1, DR3, TRAIL-R1, TRAIL-R2 e DR6) seguida pela ativação das caspase 8 e 3, e/ou pela via intrínseca mitocondrial através de membros próapoptóticos da família $\mathrm{Bcl}_{2}$, liberação de citocromo $\mathrm{C}$ e ativação das caspases 9 e 3 (SCHULTZ; HARRINGTON, 2003).

A epiderme é um tecido em contínua renovação, no qual o número de células é finamente regulado por um balanço entre proliferação, diferenciação e morte celular. Os receptores TNFR1, Fas e TRAIL são expressos em queratinócitos e a expressão e função do par Fas-FasL têm sido mais bem estudadas na epiderme. Fas está localizado na membrana basal e em queratinócitos da camada basal na epiderme humana normal (SAYAMA et al., 1994; MATSUE et al., 1995). Estudos mostraram que queratinócitos em cultura são capazes de expressar FasL e que este é funcional podendo induzir apoptose (BERTHOU et al., 1997; ARNOLD et al., 1999). No presente estudo, no entanto, não foi possível detectar a expressão de Fas e FasL na superfície de queratinócitos da linhagem HaCat tratados ou não com a SMase I de L. laeta, fato que não exclui a participação dessas proteínas no loxoscelismo in vivo.

A apoptose em queratinócitos pode também ser induzida por citocinas, em particular TNF- $\alpha$ (LASTER; WOOD; GOODING, 1988), o qual exerce suas atividades biológicas via receptores presentes em quase todas as células, incluindo queratinócitos (TREFZER et al., 1991). São conhecidos dois receptores distintos com massas moleculares de 55 e 75 kDa e em queratinócitos somente o TNFR-1 (55 kDa) é expresso (TREFZER et al., 1991). O TNF- $\alpha$ é ativo nas formas ligada à membrana e solúvel. A molécula recém-sintetizada é expressa como uma proteína transmembrana de 233 aminoácidos $(26 \mathrm{kDa})$ e seu efeito é mediado via contato célula-célula. A forma ligada à membrana pode ser clivada proteolíticamente pela TACE (TNF- $\alpha$ converting enzyme) e convertida uma proteína solúvel de 157 aminoácidos (17 kDa). 
A ligação do TNF- $\alpha$ ao TNF-R1 inicia vias de sinalização opostas que promovem ou inibem a apoptose e, neste momento, o balanço entre fatores que iniciam ou inibem a apoptose parece ser um ponto determinante (SEN, 1992; HAAKE; POLAKOWSKA, 1993). A ativação deste receptor resulta na formação do complexo do TRADD (TNF-R1 associated death domain protein)-RIP (receptor-interacting protein)-TRAF2 (TNF-R associated factor 2), o qual leva a ativação do fator de transcrição antiapoptótico NFкB (MICHEAU; TSCHOPP, 2003) e o resultado é a inibição da apoptose e a promoção da inflamação (MUPPIDI; TSCHOPP; SIEGEL, 2004). Esta via de sinalização compete com a rota onde TRADD recruta FADD (Fas-associated-death domain protein) e caspase 8 levando à morte celular (SCHULTZ; HARRINGTON, 2003).

Considerando que em queratinócitos, o TNF- $\alpha$ solúvel parece aumentar a apoptose (SCHWARZ et al., 1995; ZHUANG et al., 1999), que esta citocina está presente em culturas de queratinócitos tratados com a SMase de Loxosceles e que a apoptose de queratinócitos tratados com a toxina ou veneno é um fator chave no desenvolvimento da lesão cutânea do loxoscelismo, foi investigada a expressão dos receptores TNF-R1 e 2 em queratinócitos e o efeito do tratamento com a SMase I sobre esta expressão. Assim como encontrado por Trefzer et al. (1991), os resultados mostraram que apenas o TNF-R1 é expresso em queratinócitos e diferentemente do esperado, as células tratadas com a SMase I exibem uma reduzida expressão do receptor em sua superfície, tal redução é revertida na presença do composto inibidor 5.

Van Den Berg et al. (2002) demonstraram a ativação de metaloproteinases de membrana da família das Adamlisinas, por ação indireta do veneno de Loxosceles/SMases D em células nucleadas. Tais metaloproteases são capazes de clivar moléculas como MCP e MHCI na superfície destas células. Paixão-Cavalcante et al. (2006) observaram também a remoção de $\beta 2$-microglobulina e EGFR da superfície de queratinócitos pela ação indireta das SMases D e mais recentemente, Van Den Berg et al. (2012) demonstraram a clivagem do C5aR também pela ação de metaloproteinases de membrana da família das Adamlisinas ativadas pela SMase D presente no veneno de Loxosceles intermedia. A clivagem de moléculas ligadas a membrana, por metaloproteases da família das Adams, é bastante conhecida e no presente estudo identificamos mais uma molécula que pode estar sendo removida da superfície de queratinócitos pela ação de uma metaloprotease endógena ativada pela SMase I. No entanto, o mecanismo pelo qual as toxinas de Loxosceles induzem a ativação destas metaloproteases não é ainda completamente compreendido. Van Den Berg et 
al. (2012) sugerem que a ativação seja realizada por meio do LPA e ceramida-1-fosfato, produtos de hidrólise gerados pela SMase D ou mesmo por aumento da atividade de rafts da membrana, onde estas Adams estão localizadas, uma vez que um dos lipídeos componentes dos rafts, a esfingomielina, é alvo da ação hidrolítica das SMases D dos venenos de Loxosceles.

Apesar de as células tratadas com a SMase I exibirem uma redução da expressão dos receptores de TNF na superfície, detectada por citometria de fluxo, não se pode excluir a indução de apoptose por esta via, uma vez que, após a ativação do TNFR-I, o receptor pode sofrer um processo endocítico que implica em uma mudança conformacional e também uma modificação nas proteínas adaptadoras capazes de interagir com o receptor para a formação do complexo indutor de apoptose (revisado por CABAL-HIERRO; LAZO, 2012; SCHNEIDER-BRACHERT et al., 2004); além disso, alguns autores postulam que a sensibilidade de uma determinada célula à indução de apoptose pelo TNF- $\alpha$ não é simplesmente correlacionada ao número de receptores (BROCKHAUS et al., 1990; DEMBIC et al., 1990; TREFZER et al., 1991), portanto, para a exclusão desta via de indução da apoptose na ação das SMases D sobre os queratinócitos seriam necessárias análises em pontos da cascata de sinalização abaixo da ligação do TNF ao receptor, como o FADD, por exemplo.

O reparo de lesões na pele é um dos mais complexos processos biológicos, pois conta com muitas vias e a participação de uma complexa rede de sinalização que envolve fatores de crescimento, citocinas e quimiocinas (BARRIENTOS et al., 2008; WERNER; GROSE, 2003). Entre estas, o TGF- $\beta$ (transforming growth factor $-\beta$ ), produzido por plaquetas, macrófagos, fibroblastos e queratinócitos, tem sido apontado como principal modulador do reparo de feridas na pele, pois regula a proliferação de fibroblastos, estimula a deposição de matriz extracelular e angiogênese (LI et al., 2003; WERNER; GROSE, 2003). Três diferentes isoformas de TGF- $\beta$ têm sido descritas em células de mamíferos, cuja expressão é regulada de diferentes maneiras (SHIRAKATA, 2010), sendo que o TGF- $\beta 1$ atua na inibição da proliferação dos queratinócitos (PIETENPOL et al., 1990). Na cicatrização de feridas cutâneas, o TGF- $\beta 1$ é importante na inflamação, angiogênese, reepitelização e regeneração do tecido conjuntivo (KANE et al., 1991; KOPECKI et al., 2007), agindo como um regulador negativo da proliferação (COFFEY et al., 1988; SELLHEYER et al., 1993). Esta citocina sofre um aumento de expressão conforme o desenvolvimento da lesão, o que facilita o recrutamento de células inflamatórias adicionais, leva a um aumento do debridamento celular por macrófagos, o que pode causar mais lesão tecidual (CLARK, 1996). Além disso, TGF- $\beta 1$ 
desempenha um papel fundamental na patogênese da fibrose, induzindo e sustentando a ativação de fibroblastos quelóides (WANG et al., 2007). Foi mostrado também um aumento localizado em queimaduras, com efeito de inibir a reepitelização e aumentar a fibrose (YANG et al., 2001). Esta citocina também está envolvida na modulação de MMP-9 em alguns tipos celulares (FESTUCCIA et al., 1995; 2000).

Uma vez que esta citocina está envolvida na modulação da proliferação e diferenciação de queratinócitos, bem como em eventos importantes durante a cicatrização de feridas cutâneas, foi investigada a presença de TGF- $\beta 1$ no sobrenadante de culturas de queratinócitos humanos da linhagem HaCat tratados com a toxina SMase I, e os resultados mostraram que a toxina foi capaz de induzir a produção desta citocina, sendo que os compostos 1, 5, e 6 reduzem a produção. Tal resultado pode sugerir que a SMase também atue inibindo a proliferação dos queratinócitos durante o desenvolvimento da úlcera dermonecrótica através da possível secreção autócrina de TGF- $\beta 1$, além do recrutamento de células inflamatórias adicionais e aumento do debridamento tecidual por macrófagos. Portanto, os compostos 1,5 e 6 são eficazes na inibição destes pontos possivelmente importantes na gênese da lesão cutânea do loxoscelismo.

Na epiderme humana, a citocina IL-10 inibe a expressão de moléculas de adesão em células dendríticas, o que reduz a ligação destas células aos linfócitos T (UCHI et al., 2000). Resultados obtidos com camundongos knockout para IL-10 sugerem que esta citocina é importante no controle das reações inflamatórias, inibindo a produção de citocinas próinflamatórias como IL-1 e TNF- $\alpha$ (WANG et al., 1999). Tais dados sugerem que a IL-10, derivada de queratinócitos, pode contribuir para a manutenção do equilíbrio do microambiente imunológico da epiderme; no entanto, os dados aqui obtidos mostram que os queratinócitos humanos tratados com a SMase D não produzem esta citocina.

Citocinas pró-inflamatórias, particularmente TNF- $\alpha$, IL-1 e IL-6 são aumentadas durante a fase inflamatória da cicatrização de feridas (SINGER; CLARK, 1999). IL-1 é produzida por neutrófilos, monócitos, macrófagos e queratinócitos e é imediatamente liberada por queratinócitos após a lesão. Pode exercer um efeito autócrino aumentando a migração e proliferação dos queratinócitos, bem como ativar fibroblastos e aumentar a secreção de fatores de crescimento por estas células (TANG; GILCHREST, 1996). A IL-6 é produzida por monócitos e neutrófilos e tem se mostrado importante no início da resposta de cicatrização. Sua expressão é aumentada logo após a lesão e sustentada em feridas crônicas de difícil cicatrização (DI VITA et al., 2006; FINNERTY et al., 2006; GRELLNER; GEORG; 
WILSKE, 2000). Exerce efeitos mitogênicos e de proliferação sobre os queratinócitos, no entanto é também um potente quimioatraente para neutrófilos (GALLUCCI et al., 2004; PESCHEN et al., 1998; SATO et al., 1999). Níveis mais elevados de IL-6 são encontrados em feridas crônicas que em agudas, o que mostra que a difícil cicatrização crônica está intimamente associada a uma fase inflamtória persistente (MAST; SCHULTZ, 1996).

O TNF- $\alpha$ é produzido na epiderme por queratinócitos e células dendríticas e exerce suas funções por meio de pelo menos dois receptores. Esta citocina atrai neutrófilos e linfócitos para a pele (GROVES et al., 1995). Sua produção é aumentada por IL-1 $\alpha$ e IFN- $\gamma$, e estimula a produção de IL-1 $\alpha$ e IL-8 em queratinócitos. TNF- $\alpha$ também induz apoptose em queratinócitos (UCHI et al., 2000), além disso esta citocina é citostática para queratinócitos normais podendo então desempenhar um papel inibindo a proliferação epidermal (STOOF; BOORSMA; NICKOLOFF, 1994). Em altos níveis, especialmente por longos períodos, o TNF- $\alpha$ possui um efeito detrimental sobre a cicatrização de feridas cutâneas, pois suprime a síntese de proteínas de matriz extracelular e TIMPs (Tissue inhibitors of metalloproteinases) enquanto aumenta a expressão de MMPs (MMP-1, 2, 3, 9, 13 e MT1-MMP) (AGREN et al., 1992; RAWDANOWICZ et al., 1994; SO et al., 1992; UNEMORI; HIBBS; AMENTO, 1991). Elevados níveis de IL-1 $\beta$ induzem uma resposta similar à do TNF- $\alpha$, desta forma estas duas citocinas perpetuam uma a outra e assim amplificam este sinal (BREM et al., 2007). Além disso, TNF- $\alpha$ é capaz de induzir a ativação da via das MAPKs (ZIV et al., 2008).

Níveis elevados de TNF- $\alpha$ e IL-1 $\beta$ têm sido mostrados em feridas crônicas (TARNUZZER; SCHULTZ, 1996; WALLACE; STACEY, 1998) e, além disso, lesões de difícil cicatrização apresentam altos níveis intersticiais de colagenases, gelatinases e estromelisinas, as quais têm sido mostradas por serem induzidas por TNF- $\alpha$ e IL-1 $\beta$. Portanto, em feridas crônicas, células inflamatórias que persistem no tecido secretam altos níveis destas duas citocinas que sinergisticamente aumentam a produção de MMPs enquanto inibem os TIMPs. A aumentada atividade de MMPs degrada a matriz extracelular impedindo a migração celular e deposição de colágeno, além de degradar fatores de crescimento e seus receptores alvo na superfície das células (BREM et al., 2007).

O TNF- $\alpha$ foi associado ao efeito tóxico do veneno de Loxosceles por Tambourgi et al. (1998) que mostraram, em modelo murino, que este veneno induz uma resposta de citocinas similar ao do quadro de choque endotóxico, com alta produção de TNF- $\alpha$ e IL-6. De Souza et al. (2008) detectaram em amostras de sangue de um paciente picado por Loxosceles sp., altas concentrações de citocinas como TNF- $\alpha$ e IL-6. Dragulev et al. (2007) demonstraram a 
regulação dos genes de IL-6, IL-8, IL-1 $\beta$, TNF- $\alpha$, CXCL1, CXCL2 e CCL5 em fibroblastos tratados com o veneno de L. reclusa e Málaque et al. (1999) detectaram a presença de TNF- $\alpha$ no sobrenadante de culturas primárias de queratinócitos tratados com o veneno de L. gaucho. No presente estudo foi possível observar que queratinócitos humanos da linhagem HaCat, tratados com SMase I por 72 horas, foram capazes de produzir TNF- $\alpha$. Estes resultados sugerem que o TNF seja importante não só no loxoscelismo sistêmico, mas também pode ser relevante na indução da úlcera no loxoscelismo cutâneo, através de suas propriedades imunes, como atração de células infiltrantes, sua capacidade de induzir morte celular, ação citostática sobre queratinócitos e regulação da síntese e ativação de MMPs (HAN et al., 2001; HAN; NIEN; GARNIER, 2002; STOOF; BOORSMA; NICKOLOFF, 1994). A incubação da toxina com os inibidores 1,5 e 6 , reduziu a produção de TNF- $\alpha$ pelos queratinócitos.

Além de seu efeito sinérgico com o TNF- $\alpha$, a IL-1 induz, na epiderme, a produção de outras citocinas como IL-6, IL-8, TNF- $\alpha$ e GM-CSF. Também promove diferenciação de queratinócitos e de células dendríticas epidermais em potentes células apresentadoras de antígenos (ENK; KATZ, 1992; UCHI et al., 2000). Assim, além de a IL-6 e IL-1 $\beta$ estarem possivelmente envolvidas nos efeitos sistêmicos do loxoscelismo (TAMBOURGI et al., 1998; DE SOUZA et al., 2008), no presente estudo foi possível detectar estas citocinas no sobrenadante dos queratinócitos humanos, tratados com SMase I, o que pode indicar a participação destas no desenvolvimento da lesão cutânea, como mostrado por Dragulev et al. (2007) que observaram a expressão aumentada dos genes codificantes para IL-6, IL-1 $\beta$, IL-8 e outras quimiocinas, em fibroblastos tratados com veneno. Em relação à IL-6, o inibidor 5 aumenta significativamente a produção desta citocina, o que pode sugerir a indução do aumento da proliferação dos queratinócitos. Já a IL-1 $\beta$, foi também produzida de maneira significativa pela SMase I, no entanto, nenhum dos compostos exerce qualquer efeito sobre a produção.

Tomados em conjunto, os resultados aqui apresentados mostram que o mecanismo de ação das SMases D de Loxosceles é multifatorial e que seu estudo pode contribuir sobremaneira na assistência dada a vítimas de acidentes. Além disso, as moléculas identificadas, por técnicas de Docking molecular, foram capazes de interferir nas atividades hidrolítica, hemolítica e citotóxica das SMases D de Loxosceles, sendo portanto, ferramentas promissoras para o estudo do mecanismo multifatorial de ação destas enzimas e na busca por novas propostas terapêuticas capazes de complementar a soroterapia no tratamento dos envenenamentos por aranhas do gênero Loxosceles. 


\section{CONCLUSÕES}

Os resultados aqui obtidos permitem concluir que os estudos de docking, realizados com base na estrutura da SMase I de Loxosceles laeta, resultaram na descoberta de pelo menos duas moléculas com atividade inibitória incompetitiva, eficazes na modulação da atividade da toxina nos mecanismos de ação que cercam o desenvolvimento do loxoscelismo cutâneo e sistêmico, sendo estas moléculas, possíveis ferramentas para o desenvolvimento de terapias baseadas na inibição da SMase D, a toxina central do veneno de Loxosceles, a qual provoca todos os efeitos tóxicos presentes nos envenenamentos.

No que diz respeito ao estudo de novos mecanismos de ação da SMase D, foi possível observar que a toxina induz em queratinócitos humanos a ativação da via de sinalização ERK1/2 e que esta ativação pode contar com a possível contribuição de ROS, gerados pela ação da SMase D nestas células. Além disso, a ativação desta via pode estar relacionada ao aumento da expressão e secreção de MMP-9, importante fator que contribui para o desenvolvimento da lesão cutânea. Em relação à morte celular por apoptose, que ocorre nos queratinócitos durante a geração da úlcera, esta pode em parte ser desencadeada pelo stress oxidativo induzido nestas células pela ação da SMase e sabe-se agora que o start deste processo não se dá pela ação de receptores de morte como o Fas/FasL e o TNF-R1. Sendo este último, uma nova molécula identificada como removida da superfície da célula, por ação de metaloproteinases de membrana induzidas pela SMase D. Além disso, foi mostrado que citocinas como TGF- $\beta 1$, IL- $1 \beta$, TNF- $\alpha$ e IL-6 são secretadas pelos queratinócitos m resposta à SMase D e que podem ter papel no desenvolvimento da lesão cutânea.

Além disso, de forma geral pode-se também concluir que o uso de técnicas de docking e modelagem molecular, na busca e seleção de moléculas com a capacidade de interferir na atividade de toxinas de venenos, é uma estratégia interessante tanto na pesquisa pelo desenvolvimento de novas terapias para os envenenamentos, como na descoberta de moléculas que podem ser utilizadas como ferramentas em estudos de mecanismos de ação. 


\section{REFERÊNCIAS ${ }^{*}$}

AGREN, M. S.; TAPLIN, C. J.; WOESSNER, J. F. JR.; EAGLSTEIN, W. H.; MERTZ, P. M. Collagenase in wound healing: effect of wound age and type. J. Invest. Dermatol., v. 99, p. 709-714, 1992.

ALLER, G. S.; CARSON, J. D.; TANG, W.; PENG, H.; ZHAO, L.; COPELAND, R. A.; TUMMINO, P. J.; LUO, L. Epigallocatechin Gallate (EGCG), a major component of green tea, is a dual phosphoinositide-3-kinase/mTOR inhibitor. Biochem. Biophys. Res. Commun., v. 406, n. 2, p.194-199, 2011.

ARENZ, C.; GIANNIS, A. Synthesis of the first selective irreversible inhibitor of neutral sphingomyelinase. Angew. Chem., Int. Ed., v. 39, p. 1440, 2000.

ARENZ, C. Small molecule inhibitors of acid sphingomyelinase. Cell Physiol. Biochem., v. 26, n. 1, p.1-8, 2010.

ARNOLD, R.; SEIFERT, M.; ASADULLAH, K.; VOLK, H. D. Crosstalk between keratinocytes and $\mathrm{T}$ lymphocytes via Fas/Fas ligand interaction: modulation by citokynes. $\mathbf{J}$. Immunol., v. 162, p. 7140-7147, 1999.

ASLAM, M.; CORT, A.; YUCEL, I. Oxidative and nitrative stress markers in glaucoma. Free Radical Biol. Med., v. 45, p. 367-376, 2008.

ATKINS, J. A.; WINGO, C. W.; SOLEMAN, W. A.; FLYNN, J. F. Necrotic arachnoidism. Am. J. Trop. Med. Hyg., v. 7, p. 165, 1958.

AUER, A. I.; HERSHEY, F. B. Proceedings: Surgery for necrotic bites of the brown spider. Arch. Surg., v. 108, n. 4, p. 612-618. 1974.

BAHAR-SHANY, K.; RAVID, A.; KOREN, R. Upregulation of MMP-9 production by TNF alpha in keratinocytes and its attenuation by vitamin D. Cell Physiol., v. 222, p. 729-737, 2010.

BÁRBARO, K. C.; SOUSA, M. V.; MORTHY, L.; EICKSTEDT, V. R. D.; MOTA, I. Compared chemical properties of dermonecrotic and lethal toxins from spiders of the genus Loxosceles (Araneae) J. Protein Chem., v. 15, p. 331-343, 1996.

BARRETO, C. O.; CARDOSO, J. L.; DE CILLO, D. Viscerocutaneous form of loxoscelism and erythrocyte glucosa-6-phosphate deficiency. Rev. Inst. Med. Trop. São Paulo, v. 27, p. 264, 1985.

BARRIENTOS, S.; STOJADINOVIC, O.; GOLINKO, M. S.; BREM, H.; TOMIC-CANIC, M. Growth factors and cytokines in wound healing. Wound Repair Regen., v. 5, p. 585-601, 2008.

\footnotetext{
* De acordo com:

ASSOCIAÇÃO BRASILEIRA DE NORMAS TÉCNICAS. NBR 6023: informação e documentação: referências: elaboração. Rio de janeiro, 2002.
} 
BAXTER, C. A.; MURRAY, C. W.; CLARK, D. E.; WESTHEAD, D. R.; ELDRIDGE, M. D. Flexible docking using tabu search and an empirical estimate of binding affinity. Proteins: Structure, Function, and Genetics, v. 33, p. 367-382, 1998.

BERG, J. M.; TYMOCZKO, J. L.; STRYER, L. Biochemistry. 6th ed. New York: W. H. Freeman and Company, 2007.

BERNHEIMER, A. W.; CAMPBELL, B. J.; FORRESTER, L. J. Comparative toxinology of Loxosceles reclusa and Corynebacterium pseudotuberculosis. Science, v. 228, p. 590, 1985.

BERTHOU, C.; MICHEL, L.; SOULIÉ, A.; JEAN-LOUIS, F.; FLAGEUL, B.; DUBERTRET, L.; SIGAUX, F.; ZHANG, Y.; SASPORTES, M. Acquisition of granzyme B and Fas ligand proteins by human keratinocytes contributes to epidermal cell defense. $\mathbf{J}$. Immunol., v. 159, p. 5293-5300, 1997.

BIRKEDAL-HANSEN， H.; MOORE，W. G.; BODDEN， M. K.; WINDSOR， L. J.; BIRKEDAL-HANSEN, B.; DE CARLO, A.; ENGLER, J. A. Matrix metalloproteinases: a review. Crit. Rev. Oral Biol. Med., v. 4, p. 197-250, 1993.

BLANC, A.; PANDEY, N. R.; SRIVASTAVA, A. K. Synchronous activation of ERK 1/2, p38mapk and $\mathrm{PKB} /$ Akt signaling by $\mathrm{H}_{2} \mathrm{O}_{2}$ in vascular smooth muscle cells: potential involvement in vascular disease. Int. J. Mol. Med., v. 11, p. 229 - 234, 2003.

BOYD, D. Invasion and metastasis. Cancer Metastasis Rev., v. 15, p. 77-89, 1996.

BRAUCH, H.; ROELCKE, D.; ROTHE, U. Glycophorin A inhibits lysis by attack phase. Immunobiol., v. 165, p. 115-120, 1983.

BRASIL. Ministério da Saúde. Manual de diagnóstico e tratamento de acidentes por animais peçonhentos. Brasília: Fundação Nacional da Saúde, 2001.

BREM, H.; STOJADINOVIC, O.; DIEGELMANN, R. F.; ENTERO, H.; LEE, B.; PASTAR, I.; GOLINKO, M.; ROSENBERG, H. TOMIC-CANIC, M. Molecular markers in patients with chronic wounds to guide surgical debridement. Mol. Med., v. 13, p. 30-39, 2007.

BROCKHAUS, M.; SCHOENFELD, H. J.; SCHLAEGER, E. J.; HUNZIKER, W.; LESSLAUER, W.; LOETSCHER, H. Identification of two types of tumor necrosis factor receptors on human cell lines by monoclonal antibodies. Proc. Natl. Acad. Sci. USA, v. 87, p. 3127-3131, 1990.

BROWNER, W.S. Clinical research. A simple recipe for doing it well. Anesthesiology, v. 80, n. 4, p. 923-928, 1994.

BUDER-HOFFMANN, S.; PALMER, C.; VACEK, P.; TAATJES, D.; MOSSMAN, B. Different accumulation of activated extracellular signal-regulated kinases (ERK 1/2) and role in cell-cycle alterations by epidermal growth factor, hydrogen peroxide, or asbestos in pulmonary epithelial cells. Am. J. Respir. Cell Mol. Biol., v. 24, p. 405-413, 2001.

BUCHERL, W. Biology and venoms of the most important South American spiders of the genera Phoneutria, Loxosceles, Lycosa and Latrodectus. Am. Zool., v. 9, p. 157, 1969. 
CABAL-HIERRO, L.; LAZO, P. S. Signal transduction by tumor necrosis factor receptors. Cellular Signalling, v. 24, p. 1297-1305, 2012.

CERUTTI, P. A.; TRUMP, B. F. Inflammation and oxidative stress in carcinogenesis. Cancer Cells, v. 3, p. 1-7, 1991.

CHAPMAN, H. D.; JEFFERS, T. K.; WILLIAMS, R. B. Forty years of monensin for the controle of coccidiosis in poultry. Poultry Science, v. 89, p. 1788-1801, 2010.

CHEN, L.; RYDEL, T. J.; FEI, G. U.; DUNAWAY, M. C.; PIKUL, S.; DUNHAM, M. K.; BARNETT, B. L. Crystal structure of the Stromelysin catalytic domain at $2.0 \AA$ resolution: inhibitor-induced conformational changes. J. Mol. Biol., v. 293, p. 545-557, 1999.

CHENG, Y.; PRUSOFF, W. H. Relationship between the inhibition constant (K1) and the concentration of inhibitor which causes 50 per cent inhibition (I50) of an enzymatic reaction. Biochem. Pharmacol., v. 22, n. 23, p. 3099-108, 1973.

CHONN, A.; CULLIS, P. R.; DEVINE, D. V. The role of surface change in the activation of the classical and alternative pathways of complement by lipossomes. J. Immunol., v. 146, p. 321-327, 1991.

CISAR, C. R.; FOX, J. W.; GEREN, C. R. Screening a brown recluse spider genomic library for the gene coding the mammalian toxin using oligonucleotid probe. Toxicon, v. 27, p. 37, 1989.

CLAUS, R.; RUSSWURM, S.; MEISNER, M.; KINSCHERF, R.; DEIGNER, H. P. Modulation of the ceramide level, a novel therapeutic concept? Curr. Drug Targets, v. 1, p. 185-205, 2000.

CLAUS, R. A.; WÜSTHOLZ, A.; MÜLLER, S.; BOCKMEYER, C. L.; RIEDEL, N. H.; KINSCHERF, R.; DEIGNER, H. P. Synthesis and antiapoptotic activity of a novel analogue of the neutral sphingomyelinase inhibitor scyphostatin. Chem. Bio Chem., v. 6, p. 726, 2005.

CLARK, R. A. F. Wound repair: overview and general considerations. In: CLARK, R. A. F. (Ed.) The molecular and cellular biology of wound repair. 2nd ed. New York, NY, USA: Plenum Press, 1996. p. 3-50.

COFFEY, R. J. JR.; BASCOM, C. C.; SIPES, N. J.; GRAVES-DEAL, R.; WEISSMAN, B. E.; MOSES, H. L. Selective inhibition of growth-related gene expression in murine keratinocytes by transforming growth factor 1. Mol. Cell Biol., v. 8, p. 3088-3093, 1988.

COLNOT, C.; THOMPSON, Z.; MICLAU, T.; WERB, Z.; HELMS, J. A. Altered fracture repair in the absence of MMP9. Development, v. 130, n. 17, p. 4123-4133, 2003.

CONDE DE LA ROSA, L.; SCHOEMAKER, M. H.; VRENKEN, T. E.; BUIST-HOMAN, M.; HAVINGA, R.; JANSEN, P. L.; MOSHAGE, H. Superoxide anions and hydrogen peroxide induce hepatocyte death by different mechanisms: involvement of JNK and ERK MAP kinases. J. Hepatol., v. 44, p. 918-929, 2006. 
CORNISH-BOWDEN, A. Why is uncompetitive inhibition so rare? A possible explanation, with implications for the design of drugs and pesticides. FEBS Letters, v. 203, n. 1, p. 3-6, 1986.

D'AUTREAUX, B.; TOLEDANO, M. B. ROS as a sinalling molecules: mechanisms that generate specificity in ROS homeostasis. Nat. Rev. Mol. Cell Biol., v. 8, p. 813-824, 2007.

DE ALMEIDA, D. M.; FERNANDES-PEDROSA, M. F.; GONÇALVES-DE-ANDRADE, R. M.; MARCELINO, J. R.; GONDO-HIGASHI, H.; DE AZEVEDO, I. L. M. J.; HO, P. L.; VAN DEN BERG, C. W.; TAMBOURGI, D. V. A new anti-loxoscelic serum produced against recombinant sphingomyelinase D: results of preclinical trials. Am. Med. Hyg., v. 79, p. 463-470, 2008.

DE ANDRADE, S. A.; FERNANDES-PEDROSA, F. M.; GONÇALVES DE ANDRADE, R. M.; OLIVA, M. L. V.; VAN DEN BERG, C. W.; TAMBOURGI, D. V. Conformational changes of Loxosceles venom sphingomyelinases monitored by circular dichroism. Biochem. Biophys. Res. Commun., v. 327, p. 117-123, 2005.

DE BRUIJNE, A. W.; VAN STEVENINCK, J. Lysis of yeast cells and erythrocytes by dimethylsulfoxide. Biochem. Pharmacol., v. 21, n. 2, p. 153-162, 1972.

DE BRUIJNE, A. W.; VAN STEVENINCK, J. The influence of dimethylsulfoxide on the red cell membrane. Biochem. Pharmacol., v. 23, n. 23, p. 3247-3258, 1974.

DE OLIVEIRA, K. C.; GONÇALVES DE ANDRADE, R. M.; GIUSTI, A. L.; DIAS DA SILVA, W.; TAMBOURGI, D. V. Sex-linked variation of Loxosceles intermedia spider venoms. Toxicon, v. 37, p. 217-221, 1999.

DE OLIVEIRA, K. C.; GONÇALVES DE ANDRADE, R. M.; PIAZZA, R. M. F.; FERREIRA JUNIOR, J. M. C.; VAN DEN BERG, C. W.; TAMBOURGI, D. V. Variations in Loxosceles spider venom composition and toxicity contribute to the severy of envenomation. Toxicon, v. 45, p. 421-429, 2005.

DE SOUZA, A. L.; MALAQUE, C. M.; SZTAJNBOK, J.; ROMANO, C. C.; DUARTE, A. J.; SEGURO, A. C. Loxosceles venom-induced cytokine activation, hemolysis, and acute kidney injury. Toxicon, v. 51, p. 151-156, 2008.

DEIGNER, H. P.; HABERKORN, U.; KINSCHERF, R. Apoptosis modulator in therapy of neurodegenerative diseases. Expert Opin. Invest. Drugs, v. 9, p. 747-764, 2000.

DEIGNER, H. P.; CLAUS, R.; BONATERRA, G. A.; GEHRKE, C.; BIBAK, N.; BLAESS, M.; CANTZ, M.; METZ, J.; KINSCHERF, R. Ceramide induces aSMase expression: implications for oxLDL-induced apoptosis. FASEB J., v. 15, p. 807-814, 2001.

DEMBIC, Z.; LOETSCHER, H.; GUBLER, U.; PAN, Y. C.; LAHM, H. W.; GENTZ, R.; BROCKHAUS, M.; LESSLAUER, W. Two human TNF receptors have similar extracellular, but distinct intracellular, domain sequences. Cytokine, v. 2, p. 231-237, 1990. 
DERIJARD, B.; HIBI, M.; WU, I. H.; BARRET, T.; SU, B.; DENG, T.; KARIN, M.; DAVIS, R. J. JNK1: a protein kinase stimulated by UV light and Ha-Ras that binds and phosphorylates the c-Jun activation domain. Cell, v. 76, p. 1025-1037, 1994.

DESAI, A.; MILLER, M. J.; GOMEZ, H. F.; WARREN, J. S. Loxosceles deserta spider venom induces the expression of vascular endothelial growth factor (VEGF) in keratinocytes. Inflammation, v. 24, p. 1-9, 2000.

DEY, R.; CHEN, L. In search of allosteric modulators of a7-nAChR by solvent density guided virtual screening. J. Biomol. Struct. Dyn., v. 28, n. 5, p. 695-715, 2011.

DING, A. H.; NATHAN, C. F.; STUEHR, D. J. Release of reactive nitrogen intermediates and reactive oxygen intermediates from mouse peritoneal macrophages. Comparison of activating cytokines and evidence for independent production. J. Immunol., v. 141, n. 7, p. 2407-2412, 1988.

DI VITA, G.; PATTI, R.; D’AGOSTINO, P.; CARUSO, G.; ARCARA, M.; BUSCEMI, S.; BONVENTRE, S.; FERLAZZO, V.; ARCOLEO, F.; CILLARI, E. Cytokines and growth factors in wound drainage fluid from patients undergoing incisional hernia repair. Wound Repair Regen., v. 14, p. 259-264, 2006.

DORR, R. T.; SOBLE, M. J.; LIDDIL, J. D.; KELLER, J. H. Mitomycin C skin toxicity studies in mice: reduced ulceration and altered pharmacokinetics with topical Dimethyl Sulfoxide. J. Clin. Oncol., v. 4, p. 1399-1404, 1986.

DRAGULEV, B.; BAO, Y.; RAMOS-CERRILLO, B.; VAZQUEZ, H.; OLVERA, A.; STOCK, R.; ALGARON, A.; FOX, J. W. Upregulation of IL-6, IL-8, CXCL1, and CXCL2 dominates gene expression in human fibroblast cells exposed to Loxosceles reclusa sphingomyelinase D: insights into spider venom dermonecrosis. J. Invest. Dermatol., v. 127, n. 5, p. 1264-1266, 2007.

ELSTON, D. M.; MILLER, M. S.; YOUNG, R. J. EGGERS, J. S.; McGLASSON, M. D. SCHIMIDT, W. H.; BRUSH, A. Comparation of colchicines, dapsone, triamcinolone and diphenhydramine therapy for the treatment of brown recluse spider envenomation. Arch. Dermatol., v. 141, p. 595-597, 2005.

ENK, A. H.; KATZ, S. I. Identification and induction of keratinocyte-derived IL-10. J. Immunol., v. 149, n. 1, p. 92-95, 1992.

ERNST, J. D. Epitope mapping of annexin I. Antibodies that compete with phospholipids and calcium recognize amino acids. Biochem. J., v. 289, p. 539-542, 1993.

FEITOSA, L.; GRAMSKI, W.; VEIGA, S. S. Detection and characterization of metalloproteinases with gelatinolytic, fibronectinolytic and fibrinogenolytic activities in Brown Spider (Loxosceles intermedia) venom. Toxicon, v. 36, p. 1039-1051, 1998.

FERNANDES-PEDROSA, M. F.; JUNQUEIRA DE AZEVEDO, I. L.; GONÇALVES DE ANDRADE, R. M.; VAN DEN BERG, C. W.; RAMOS, C. R.; HO, P. L.; TAMBOURGI, D. $\mathrm{V}$. Molecular cloning and expression of a functional dermonecrotic and haemolytic factor from Loxosceles laeta venom. Biochem. Biophys. Res. Commun., v. 298, p. 638-645, 2002. 
FESTUCCIA, C.; VICENTINI, C.; FIRMA, N.; ACETO, G.; ZAZZERONI, F.; BOLOGNA, M. Plasminogen activator activities in short-term tissue cultures of benign prostatic hyperplasia and prostatic carcinoma. Oncol. Res., v. 7, p. 131-138, 1995.

FESTUCCIA, C.; ANGELUCCI, A.;GRAVINA, G. L.; VILLANOVA, I.; TETI, A. ABINI, A.; BOLOGNA, M. Osteoblast-derived TGF- $\beta 1$ modulates matrix degrading protease expression and activity in prostate cancer cells. Int. J. Cancer, v. 85, p. 407-415, 2000.

FINNERTY, C. C.; HERNDON, D. N.; PRZKORA, R.; PEREIRA, C. T.; OLIVEIRA, H. M.; QUEIROZ, D. M.; ROCHA, A. M.; JESCHKE, M. G. Cytokine expression profile over time in severely burned pediatric patients. Shock, v. 26, p. 13-19, 2006.

FINNEY, D. J. Probit analysis. Cambridge, England: Cambridge University Press, 1971. 31 p.

FISCHER, M. L.; VASCONCELLOS NETO, J. Microhabitats occupied by Loxosceles intermedia and Loxosceles laeta (ARANAE: SICARIIDAE) in Curitiba, Paraná. Brazil. J. Med. Entomol., v. 42, p. 756-765, 2005.

FOOD AND DRUG ADMINISTRATION. Guidance for Industry S1C (R2): Dose Selection for Carcinogenicity Studies. Revision I, ICH, USA, 2008.

FORRESTER, L. J.; BARRET, J. T.; CAMPBELL, B. Red blood cells lysis induced by the venom of the brown spider: the role of sphingomielinase D. J. Arch. Biochem. Biophys., v. 187, p. 355-365, 1978.

FUTRELL, J. M. Loxoscelism. Am. J. Med. Sci., v. 304, p. 261, 1992.

GALlUCCI, R. M.; SLOAN, D. K.; HECK, J. M.; MURRAY, A. R.; O’DELL, S. J. Interleukin 6 indirectly induces keratinocyte migration. J. Invest. Dermatol., v. 122, p. 764$772,2004$.

GARNIER, J.; GIBRAT, J. F.; ROBSON, B. GOR secondary structure prediction method version IV. Meth. Enzymol., v. 266, p. 540-553, 1996.

GERTSCH, W. J.; ENNIK, F. The spider genus Loxosceles in North America, Central America and West Indies (Araneae: Loxoscelidae). Bull. Amer. Mus. Nat. Hist., v. 175, p. 264-360, 1983.

GONÇALVES DE ANDRADE, R. M.; DE OLIVEIRA, K. C.; GIUSTI, A. L.; DIAS DA SILVA, W.; TAMBOURGI, D. V. Ontogenetic development of Loxosceles intermedia spider venom. Toxicon, v. 37, p. 627-632, 1999.

GONÇALVES DE ANDRADE, R. M.; TAMBOURGI, D. V. First record on Loxosceles laeta (Nicolet, 1849) (Aranae: Sicariidae) in the West Zone of São Paulo city, São Paulo, Brazil, and considerations regarding geographic distribuition. Rev. Soc. Bras. Med. Trop., v. 36, p. 425-426, 2003. 
GOWRAVARAM, M. R.; TOMCZUK, B. E.; JOHNSON, J. S.; DELECKI, D.; COOK, E. R.; GHOSE, A. K.; MATHIOWETZ, A. M.; SPURLINO, J. C.; RUBIN, B.; SMITH, D. L.; PULVINO, T.; WAHL, R. C. Inhibition of matrix metalloproteinases by hydroxamates containing heteroatom-based modifications of the P1' group. J. Med. Chem., v. 38, p. 2570, 1995.

GRELLNER, W.; GEORG, T.; WILSKE, J. Quantitative analysis of proinflammatory cytokines (IL-1beta, IL-6, TNF-alpha) in human skin wounds. Forensic Sci. Int., v. 113, p. 251-264, 2000.

GRIFFITH, C. E.; ZHANG, W.; WANGE, R. L. ZAP-70-dependent and -independent activation of Erk in Jurkat T cells: differences in signaling induced by $\mathrm{H}_{2} \mathrm{O}_{2}$ and $\mathrm{CD} 3$ crosslinking. J. Biol. Chem., v. 273, p. 10771-10776, 1998.

GROVES, R W.; MIZUTANI, H.; KIEFFER, J. D.; KUPPER, T. S. Inflammatory skin disease in transgenic mice that express high levels of interleukin 1 alpha in basal epidermis. Proc. Natl. Acad. Sci. USA., v. 92, n. 25, p. 11874-8, 1995.

GU, B. H.; MINH, N. V.; LEE, S. H.; LIM, S. W.; LEE, Y. M.; LEE, K. S.; KIM, D. K. Deoxyschisandrin inhibits $\mathrm{H}_{2} \mathrm{O}_{2}$-induced apoptotic cell death in intestinal epithelial cells through nuclear factor-kappa B. Int. J. Mol. Med., v. 26, p. 401-406, 2010.

GUM, R.; WANG, H.; LENGYEL, E.; JUAREZ, J.; BOYD, D. Regulation of 92 kDa type IV collagenase expression by the jun aminoterminal kinase- and the extracellular signal-regulated kinase-dependent signaling cascades. Oncogene, v. 14, p. 1481-1493, 1997.

GUMILA, C.; ANCELIN, M. L.; DELORT, A. N.; JEMINET, G.; VIAL, H. J. Characterization of the potent in vitro and in vivo antimalarial activities of ionophore compounds. Antimicrobial Agents and Chemotherapy, v. 41, n. 3, p. 523-529, 1997.

GUPTA, A.; SINGH, R. L.; RAGHUBIR, R. Antioxidant status during cutaneous wound healing in immunocompromised rats. Mol. Cell Biochem., v. 241, p. 1-7, 2002.

GUPTA, A.; ROSENBERGER, S. F.; BOWDEN, T. Increased ROS levels contribute to elevated transcription factor and MAP kinase activities in malignantly progressed mouse keratinocyte cell lines. Carcinogenesis, v. 20, n. 11, p. 2063-2073, 1999.

HAAKE, A. R.; POLAKOWSKA, R. R. Cell death by apoptosis in epidermal biology. J. Invest. Dermatol., v. 101, p. 107-112, 1993.

HAN, Y. P.; TUAN, T. L.; HUGHES, M.; WU, H.; GARNER, W. L. Transforming growth factor-beta and tumor necrosis factor-alpha mediated induction and proteolytic activation of MMP-9 in human skin. J. Biol. Chem., v. 276, p. 22341-22350, 2001.

HAN, Y. P.; NIEN, Y. D.; GARNER, W. L. Tumor necrosis factor-alpha induced proteolytic activation of pro-matrix metalloproteinase 9 by human skin is controlled by down-regulating tissue inhibitor of metalloproteinase- 1 and mediated by tissue-associated chymotrypsin-like proteinase. J. Biol. Chem., v. 277, p. 27319-27327, 2002. 
HARTMANN, G.; WEIDNER, K. M.; SCHWARZ, H.; BIRCHMEIER, W. The motility signal of scatter factor/hepatocyte growth factor mediated through the receptor tyrosine kinase met requires intracellular action of Ras. J. Biol. Chem., v. 269, p. 21936-21939, 1994.

HERSHEY, F. B.; AULENBACHER, C. E. Surgical treatment of brown spider bites. Ann. Surg., v. 170, n. 2, p. 300-308, 1969.

HIMELSTEIN, B. P.; LEE, E. J.; SATO, H.; SEIKI, M.; MUSCHEL, R. J. Transcriptional activation of the matrix metalloproteinase-9 gene in an H-ras and v-myc transformed rat embryo cell line. Oncogene, v. 14, p. 1995-1998, 1997.

HOGAN, C. J.; BARBARO, K. C.; WINKEL, K. Loxoscelism: old obstacles, new directions. Ann. Emerg. Med., v. 44, n. 6, p. 608-24, 2004.

HOLVOET, S.; VINCENT, C.; SCHIMITT, D.; SERRES, M. The inhibition of MAPK pathway is correlated with down-regulation of MMP-9 secretion induced by TNF-alpha in human keratinocytes. Exp. Cell Res., v. 290, p. 108-119, 2003.

HORN, J. R.; SHOICHET, B. K. Allosteric inhibition through core disruption. J. Mol. Biol., v. 336, n. 5, p. 1283-91, 2004.

HUANG, R. P.; PENG, A.; GOLARD, A.; HOSSAIN, M. Z.; HUANG, R.; LIU, Y. G.; BOYNTON, A. L. Hydrogen peroxide promotes transformation of rat liver non neoplastic epithelial cells through activation of epidermal growth factor receptor. Mol. Carcinog., v. 30, p. 209-217, 2001.

IMAGAWA, H.; ODA, M.; TAKEMOTO, T.; YAMAUCHI, R.; YOSHIKAWA, T.; YAMAMOTO, H.; NISHIZAWA, M.; TAKAHASHI, H.; HASHIMOTO, M.; YABIKU, K.; NAGAHAMA, M.; SAKURAI, J. Synthesis and evaluation of novel phosphate ester analogs as neutral sphingomyelinase inhibitors. Bioorganic e Medicinal Chemistry Letters, v. 20, p. 3868-3871, 2010.

INOUE, M.; YOKOTA, W.; MURUGESH, M. G.; IZUHARA, T.; KATOH, T. Total synthesis of (+)-scyphostatin, a potent and specific inhibitor of neutral sphingomyelinase. Angew. Chem. Int. Ed., v. 43, p. 4207, 2004.

IRWIN, J. J.; SHOICHET, B. K. ZINC - a free database of commercially available compounds for virtual screening. J. Chem. Inf. Model, v. 45, p. 177-182, 2005.

IRWIN, J. J.; STERLING, T.; MYSINGER, M. M.; BOLSTAD, E. S.; COLEMAN, R. G. ZINC: A Free Tool to Discover Chemistry for Biology. J. Chem. Inf. Model, v. 52, n. 7, p. 1757-1768, 2012.

JALINK, K.; HORDIJK, P. L.; MOOLENAAR, W. H. Growth factor-like effects of lysophosphatidic acid, a novel lipid mediator. Biochem. Biophys. Acta, v. 1198, p. 185-196, 1994. 
JENSON, P. J.; RODECK, U. Autocrine/paracrine regulation of keratinocyte urokinase plasminogen activator through the TGF-alpha/EGF receptor. J. Cell. Physiol., v. 155, p. 333339, 1993.

JIMENEZ, L. A.; ZANELLA, C.; FUNG, H.; JANSSEN, Y. M.; VACEK, P.; CHARLAND, C.; GOLDBERG, J.; MOSSMAN, B. T. Role of extracellular signal-regulated protein kinases in apoptosis by asbestos and $\mathrm{H}_{2} \mathrm{O}_{2}$. Am. J. Physiol., v. 273, p. L1029-L1035, 1997.

JOHNSON, G. L.; LAPADAT, R. Mitogen-activated protein kinase pathways mediated by ERK, JNK, and p38 protein kinases. Science, v. 298, p. 1911-1912, 2002.

JONES, D. T. Protein secondary structure prediction based on position-specific scoring matrices. J. Mol. Biol., v. 292, n. 2, p. 195-202, 1999.

JONES, G.; WILLET, P.; GLEN, R. C. Molecular recognition of receptor sites using genetic algorithm with a description of desolvation. J. Mol. Biol., v. 245, p. 43-53, 1995.

JONES, G.; WILLET, P.; GLEN, R. C.; LEACH, A. R.; TAYLOR, R. Development and validation of a genetic algorithm for flexible docking. J. Mol. Biol., v. 267, p. 727-748, 1997.

JONES, S. J.; WORRALL, A. F.; CONNOLLY, B. A. Site-directed mutagenesis of the catalytic residues of bovine pancreatic deoxyribonuclease I. J. Mol. Biol., v. 264, n. 5, p. 1154-1163, 1996.

KAAPRO, A.; OJANEN, J. Protein docking. lce, HUT, 2002. Disponível em: <http://www.lce.hut.fi/teaching/S-114.500/k2002/Protdock.pdf>. Acesso em: 04 jul. 2012.

KANE, C. J.; HEBDA, P. A.; MANSBRIDGE, J. N.; HANAWALT, P. C. Direct evidence for spatial and temporal regulation of transforming growth factor beta 1 expression during cutaneous wound healing. J. Cell Physiol., v. 148, p. 157-173, 1991.

KELICEN, P.; CANTUTI-CASTELVETRI, I.; PEKINER, C.; PAULSON, K. E. The spin trapping agent $\mathrm{PBN}$ stimulates $\mathrm{H}_{2} \mathrm{O}_{2}$-induced Erk and $\mathrm{Src}$ kinase activity in human neuroblastoma cells. Neuroreport, v. 13, p. 1057-1061, 2002.

KIM, B. Y.; HAN, M. J.; CHUNG, A. S. Effects of reactive oxygen species on proliferation of Chinese hamster lung fibroblast (V79) cells. Free Radic. Biol. Med., v. 30, p. 686-698, 2001.

KIRCHMAIR, J.; DISTINTO, S.; LIEDL, K. R.; MARKT, P.; ROLLINGER, J. M.; SCHUSTER, D.; SPITZER, G. M.; WOLBER, G. Development of anti-viral agents using molecular modeling and virtual screening techniques. Infect. Disord. Drug Targets, v. 11, n. 1, p. 64-93, 2011.

KLEMKE, R.; YEBRA, M.; BAYNA, E.; CHERESH, D. A. Receptor tyrosine kinase signaling required for integrin alpha $\mathrm{v}$ beta 5 -directed cell motility but not adhesion on vitronectin. J. Cell Biol., v. 127, p. 859-866, 1994. 
KOPECKI, Z.; LUCHETTI, M. M.; ADAMS, D. H.; STRUDWICK, X.; MANTAMADIOTIS, T.; STOPPACCIARO, A.; GABRIELLI, A.; RAMSAY, R. G.; COWIN, A. J. Collagen loss and impaired wound healing is associated with c-Myb deficiency. J. Pathol., v. 211, p. 351-361, 2007.

KOTHANDAN, G.; GADHE, C. G.; MADHAVAN, T.; CHO, S. J. Binding site analysis of CCR2 through in silico methodologies Docking, CoMFA and CoMSIA (In silico analysis of CCR2 antagonists). Chem. Biol. Drug Des., v. 78, n. 1, p. 161-174, 2011.

KUMAR, P.; SHRIVASTAVA, B.; PANDEYA S. N.; STABLES, J. P. Design, synthesis and potential $6 \mathrm{~Hz}$ psychomotor seizure test activity of some novel 2-(substituted)-3\{[substituted]amino\}quinazolin-4(3H)-one. Eur. J. Med. Chem., v. 46, n. 4, p. 1006-1018, 2011.

KUMIN, A.; HUBER, C.; RUCLICKE, T.; WOLF, E. WERNER, S. Peroxiredoxin 6 is a potent cytoprotective enzyme in the epidermis. Am. J. Pathol., v. 169, p. 1194-1205, 2006.

KUMIN, A.; SCHÄFER, M.; EPP, N.; BUGNON, P.; BORN-BERCLAZ, C.; OXENIUS, A.; KLIPPEL, A.; BLOCH, W.; WERNER, S. Peroxiredoxin 6 is required for blood vessel integrity in wounded skin. J. Cell Biol., v. 179, p. 747-760, 2007.

KYRIASKIS, J. M.; BANAERJEE, P.; NIKOLAKAKI, E.; DAI, T.; RUBIE, E. A.; AHMED, M. F.; AVRUCH, J.; WOODGETT, J. R. The stress-activated protein kinase subfamily of c-Jun kinases. Nature, v. 369, p. 156-160, 1994.

LAEMMLI, U. K. Cleavage of structural proteins during the assembly of the head of bacteriophage T4. Nature, v. 227, p. 680-685, 1970.

LASTER, S. M.; WOOD, J. G.; GOODING, L. R. J. Tumor necrosis factor can induce both apoptic and necrotic forms of cell lysis. J. Immunol., v. 141, p. 2629-2634, 1988.

LEE, K.; ESSELMAN, W. J. Inhibition of PTPs by $\mathrm{H}_{2} \mathrm{O}_{2}$ regulates the activation of distinct MAPK pathways. Free Radic. Biol. Med., v. 33, p. 1121-1132, 2002.

LEE, D. H.; KIM, S. H.; AHN, K. H.; KIM, S. K.; CHOIL, J. M.; JIL, J. E.; WON, J. H.; PARK, Y. H.; LIM, C.; KIM, S.; KIM, D. K. Identification and evaluation of neutral sphingomyelinase 2 inhibitors. Arch. Pharm. Res., v. 34, n. 2, p. 229-236, 2011.

LEE, S. e LYNCH, K. R. Brown recluse spider (Loxosceles reclusa) venom phospholipase D (PLD) generates lysophosphatidic acid (LPA). Biochem. J., v. 391, p. 317-323, 2005.

LEE, Y.; KIM, H., KIM, S.; KIM, K. H.; CHUNG, J. H. Activation of toll-like receptors 2, 3 or 5 induces matrix metalloproteinase- 1 and -9 expression with the involvement of MAPKs and NF-kappaB in human epidermal keratinocytes. Exp. Dermatol., v. 19, p. e44-e49, 2010.

LEIROS, I.; MCSWEENEY, S.; HOUGH, E. The reaction mechanism of Phospholipase D from Streptomyces sp. strain PMF. Snapshots along the reaction pathway reveal a pentacoordinate reaction intermediate and an unexpected final product. J. Mol. Biol., v. 339, p. 805-820, 2004. 
LI, J. S.; WANG, H.; ZHANG, X.; ZHANG, H. S. Spectrofluorimetric determination of total amount of nitrite and nitrate in biological sample with a new fluorescent probe 1,3,5,7etramethyl-8-(3',4'-diaminophenyl)-difluoroboradiaza-s-indacence. Talanta, v. 61, n. 6, p. 797-802, 2003.

LINDSEY, M. L.; ESCOBAR, G. P.; DOBRUCKI, L. W.; GOSHORN, D. K.; BOUGES S.; MINGOIA, J. T.; DAVID, M.; MCCLISTER, JR.; HAILI, S.; GANNON, J.; MACGILLIVRAY, C.; LEE, R. T.; SINUSAS, A. J.; SPINALE, F. G. Matrix metalloproteinase-9 gene deletion facilitates angiogenesis after myocardial infarction. Am. J. Physiol. Heart. Circ. Physiol., v. 290, p. H232-239, 2006.

LIPINSKI, C. A.; LOMBARDO, F.; DOMINY, B. W.; FEENEY, P. J. Experimental and computational approaches to estimate solubility and permeability in drug discovery and development settings. Adv. Drug Deliv. Rev., v. 46, p. 3-26, 2001.

LIPINSKI, C. A. Lead- and drug-like compounds: the rule-of-five revolution. Drug Discovery Today: Technologies, v. 1, n. 4, p. 337-341, 2004.

LOWRY, O. H.; ROSEBROUGH, N. J.; FARR, A. L.; RANDALL, R. J. Protein measurement with the Folin phenol reagent. J. Biol. Chem., v. 193, n. 1, p. 265-275, 1951.

LUCAS, S. M. Aranhas de interesse médico no Brasil. In: CARDOSO, J. L. C.; FRANÇA, F. O. S.; WEN, F. H.; MÁLAQUE, C. M. S.; HADDAD, V. JR. (Ed.) Animais Peçonhentos do Brasil: biologia, clínica e terapêutica dos acidentes. São Paulo: Sarvier, 2003. p. 141-149.

LYONS, J. G.; BIRKEDAL-HANSEN, B.; PIERSON, M. C.; WHITELOCK, J. M.; BIRKEDAL-HANSEN, H. Interleukin-1 beta and transforming growth factoralpha/epidermal growth factor induce expression of $\mathrm{M}(\mathrm{r})$ 95,000 type IV collagenase/gelatinase and interstitial fibroblast-type collagenase by rat mucosal keratinocytes. J. Biol. Chem., v. 268, p. 19143-19151, 1993.

MACKINNON, J. E.; WITKIND, J. Necrotic arachnidism. An. Fac. Med. Univ. Repub. Montev. Urug., v. 38, n. 3-4, p. 75-100, 1953.

MAKINO, S.; KUNTZ, I.D. Automated flexible ligand docking method and its application for database search. J. Comput. Chem., v. 18, p. 1812-1825, 1997.

MÁlAQUE, C. M. S.; SANTOS, M. O. S.; ANDRADE, D. R. Production of TNF- $\alpha$ by primary cultures of human keratinocytes challenged with Loxosceles gaucho venom. Rev. Inst. Med. Trop. São Paulo, v. 41, n. 3, p. 179-182, 1999.

MÁlAQUE, C. M. S.; CASTRO-VALENCIA, J. E.; CARDOSO, J. L. C.; FRANÇA, F. O. S.; BÁRBARO, K. C.; FAN, H. W. Clinical and epidemiological features of definitive and presumed loxoscelism in São Paulo, Brazil. Rev. Inst. Med. Trop. São Paulo, v. 44, n. 3, p. 139-143, 2002.

MAST, B. A.; SCHULTZ, G. S. Interactions of cytokines, growth factors, and proteases in acute and chronic wounds. Wound Repair Regen., v. 4, p. 411-420, 1996. 
MATSUE, H.; KOBAYASHI, H.; HOSOKAWA, T.; AKITAYA, T.; OHKAWARA, A. Keratinocytes constitutively express the Fas antigen that mediates apoptosis in IFN gammatreated cultured keratinocytes. Arch. Dermatol. Res., v. 287, n. 3-4, p. 315-320, 1995.

MATSUO, Y.; YAMADA, A.; TSUKAMOTO, K.; TAMURA, H. O.; IKEZAWA, H.; NAKAMURA, H.; NISHIKAWA, K. A distant evolutionary relationship between bacterial and Sphingomyelinase and mammalian DNAse I. Protein science, v. 5, n. 12, p. 2459-2467, 1996.

McCAWLEY, L. J.; OBRIEN, P.; HUDSON, L. G. Epidermal growth factor (EGF) and scatter factor/hepatocyte growth factor (SF/HGF) mediated keratinocyte migration is coincident with induction of matrix metalloproteinase (MMP)-9. J. Cell Physiol., v. 176, p. 255-265, 1998.

McNAMARA, P. J.; CUEVAS, W. A.; SONGER, J. G. Toxic phospholipases D of Corynebacterium pseudotuberculosis, C. ulcerans and Arcanobacterium haemolyticum: cloning and sequence homology. Gene, v. 156, p. 113-118, 1995.

MICHEAU, O.; TSCHOPP, J. Induction of TNF receptor I-mediated apoptosis via two sequential signaling complexes. Cell, v. 114, p. 181-190, 2003.

MISHRA, H.; SINGH, N.; LAHIRI, T.; MISRA, K. A comparative study on the molecular descriptors for predicting drug-likeness of small molecules. Bioinformation, v. 3, n. 9, p. 384-388, 2009.

MOOLENAAR, W. H. LPA: a novel lipid mediator with diverse biological actions. Trends Cell Biol., v. 4, p. 213-219, 1994.

MOOLENAAR, W. H. Lysophosphatidic acid, a multifunctional phospholipid messenger. J. Biol. Chem., v. 22, n. 2, p. 12949-12952, 1995.

MORRISSEY, J. H. Silver stain for proteins in polyacrylamide gels: a modified procedure with enhanced uniform sensitivity. Anal. Biochem., v. 117, p. 307-310, 1980.

MOSELEY, R.; HILTON, J. R.; WADDINGTON, R. J.; HARDING, K. G.; STEPHENS, P.; THOMAS D. W. Comparison of oxidative stress biomarker profiles between acute and chronic wound environments. Wound Repair Regen., v. 12, p. 419-429, 2004.

MOSMANN, T. Rapid colorimetric assay for cellular growth and survival: application to proliferation and cytotoxicity assays. J. Immunol. Methods, v. 65, n. 1-2, p. 55-63, 1983.

MUNZ, B.; FRANK, S.; HUBNER, G.; OLSEN, E.; WERNER, S. A novel type of gluthatione peroxidase: expression and regulation during wound repair. Biochem. J., v. 326, n. 2, p. 579-585, 1997.

MUPPIDI, J. R.; TSCHOPP, J.; SIEGEL, R. M. Life and death decisions: secondary complexes and lipid rafts in TNF receptor family signal transduction. Immunity, v. 21, p. 461-465, 2004. 
MURAKAMI, M. T.; FERNANDES-PEDROSA, M. F.; TAMBOURGI, D. V.; ARNI, R. K. Structural basis for metal ion coordination and the catalytic mechanism of sphingomyelinases D. J. Biol. Chem., v. 280, n. 14, p. 13658-13664, 2005.

MURAKAMI, M. T.; FERNANDES-PEDROSA, M. F.; DE ANDRADE, A. S.; GABDOULKHAKOV, A.; BETZEL, C.; TAMBOURGI, D. V.; ARNI. A. K. Structural insights into the catalytic mechanism of sphingomyelinases D and evolutionary relationship to glycerophosphodiester phosphodiesterases. Biochem. Biophys. Res. Commun., v. 342, p. 323-329, 2006.

NARA, F.; TANAKA, M.; MASUDA-INOUE, S.; YAMASATO, Y.; DOI- YOSHIOKA, H.; SUZUKI KONAGAI, K.; KUMAKURA, S.; OGITA, T. Biological activities of scyphostatin, a neutral sphingomyelinase inhibitor from a discomycete, Trichopeziza mollissima. J. Antibiot., v. 52, p. 531, 1999a.

NARA, F.; TANAKA, M.; HOSOYA, T.; SUZUKI-KONAGAI, K.; OGITA, T. Scyphostatin, a neutral sphingomyelinase inhibitor from a discomycete, Trichopeziza mollissima: taxonomy of the producing organism, fermentation, isolation, and physicochemical properties. J. Antibiot., v. 52, p. 525, 1999 b.

NORMENT , B. R.; JONG, Y. S.; HEITZ, J. R. Separation and characterization of venom components in Loxosceles recluse - III. Hydrolytic enzyme activity. Toxicon, v. 17, n. 6, p. 539-548, 1979.

OJHA, N.; ROY, S.; HE, G.; BISWAS, S.; VELAYUTHAM, M.; KHANNA, S.; KUPPUSAMY, P.; ZWEIER, J. L.; SEN, C. K. Assessment of wound site redox environment and the significance of rac2 in cutaneous healing. Free Radicals Biol. Med., v. 44, p. 682-691, 2008.

OKADA, N.; YASUDA, T.; TSUMITA, T.; SHINOMIYA, H.; UTSUMI, S.; OKADA, H. Regulation by glycophorin of $\mathrm{C}$ activation via the alternative pathway. Biochem. Biophys. Commun., v. 108, p. 770-775, 1982.

OKUDAIRA, C.; IKEDA, Y.; KONDO, S.; FURUYA, S.; HIRABAYASHI, Y.; KOYANO, T.; SAITO, Y.; UMEZAWA, K. Inhibition of acidic sphingomyelinase by xanthone compounds isolated from Garcinia speciosa. J. Enzyme Inhibition, v. 15, p. 129-138, 2000 .

OPREA, T. I.; DAVIS, A. M.; TEAGUE, S. J.; LEESON, P. D. Is there a difference between leads and drugs? A historical perspective. J. Chem. Inf. Comput. Sci., v. 41, n. 5, p. 1308$1315,2005$.

ORGANISATION FOR ECONOMIC CO-OPERATION AND DEVELOPMENT (OECD). Guidance $n^{\circ}$ 129: Guidance document on using cytotoxicity tests to estimate starting doses for acute oral systemic toxicity tests. Paris: OECD, 2010.

PAIXÃO-CAVALCANTE, D.; VAN DEN BERG, C. W.; FERNANDES-PEDROSA, M. F.; GONÇALVES DE ANDRADE, R. M.; TAMBOURGI, D. V. Role of matrix metalloproteinases in HatCat keratinocytes apoptosis induced by Loxosceles venom sphingomyelinase D. J. Invest. Dermatol., v. 126, p. 61-68, 2006. 
PAIXÃO-CAVALCANTE, D.; VAN DEN BERG, C. W.; GONÇALVES DE ANDRADE, R. M.; FERNANDES-PEDROSA, M. F.; OKAMOTO, C. K.; TAMBOURGI, D. V. Tetracycline protects against dermonecrosis induced by Loxosceles spider venom. J. Invest. Dermatol., v. 127, p. 1410-1418, 2007.

PATEL, K. D.; MODUR, V.; ZIMMERMAN, G. A.; PRESCOTT, S. M.; MCINTYRE, T. M. The necrotic venom of the brown spider induces dysregulated endothelial cell-dependent neutrophil activation. Differential induction of GM-CSF, IL-8 and E-selectin expression. J. Clin. Invest., v. 94, p. 631-642, 1994.

PAULI, I.; PUKA, J.; GUBERT, I. C.; MINOZZO, J. C. The efficacy of antivenom in loxoscelism treatment. Toxicon, v. 48, n. 2, p. 123-137, 2006.

PESCHEN, M.; GRENZ, H.; BRAND-SABERI, B.; BUNAES, M.; SIMON, J. C.; SCHOPF, E.; VANSCHEIDT, W. Increased expression of platelet- derived growth factor receptor alpha and beta and vascular endothelial growth factor in the skin of patients with chronic venous insufficiency. Arch. Dermatol. Res., v. 290, p. 291-297, 1998.

PITSINOS, E. N.; WASCHOLOWSKI, V.; KARALIOTA, S.; RIGOU, C.; COULADOUROS, E. A.; GIANNIS, A. Synthesis and evaluation of three novel scyphostatin analogues as neutral sphingomyelinase inhibitors. Chem. Biochem., v. 4, p. 1223, 2003.

PIZZI, T. A histopathological study on necrotic arachnidism by Loxosceles laeta. Bol. Chil. Parasitol., v. 30, p. 34-36, 1957.

PLATNICK, N. I. The World Spider Catalogue. version 10.0. American Museum of Natural History, 2011. Disponível em: <http://research.amnh.org/entomology/spiders/ catalogue/index.html>. Acesso em: 11 nov. 2011.

PORTARO, F. C. V.; MURAMATSU, D.; GUILHERME, P. BÁRBARO, K. C. Presence of metalloproteinases and serine-proteases in the Loxosceles gaucho crude venom. In: REUNIÃO ANUAL DA SOCIEDADE BRASILEIRA DE BIOQUÍMICA E BIOLOGIA MOLECULAR, 28., 1999, Caxambú, MG. Resumos... Caxambú, MG, 1999.

PRETEL, F.; GONÇALVES DE ANDRADE, R. M.; MAGNOLI, F. C.; SILVA, M. E. R.; FERREIRA Jr, J.M.C.; VAN DEN BERG, C. W.; TAMBOURGI, D. V. Analysis of the potential of venom from Loxosceles Adelaida, a Brazilian brown spider from karstic areas. Toxicon, v. 45, p. 449-458, 2005.

QUI, M. S.; GREEN, S. H. PC12 cell neuronal differentiation is associated with prolonged p21ras activity and consequent prolonged ERK activity. Neuron, v. 9, p. 705-717, 1992.

RAHMAN, S. S.; SIMOVIC, I.; GIBBONS, S.; ZLOH, M. In silico screening for antibiotic escort molecules to overcome efflux. J. Mol. Model, v. 17, n. 11, p. 2863-2872, 2011.

RAREY, M.; KRAMER, B.; LENGAUER, T.; KLEBE, G. A fast flexible docking method using an incremental construction algorithm. J. Mol. Biol., v. 261, n. 3, p. 470-489, 1996. 
RAWDANOWICZ, T. J.; HAMPTON, A. L.; NAGASE, H.; WOOLLEY, D. E.; SALAMONSEN, L. A. Matrix metalloproteinase production by cultured human endometrial stromal cells: identification of interstitial collagenase, gelatinase-A, gelatinase- $B$, and stromelysin-1 and their differential regulation by interleukin- 1 alpha and tumor necrosis factor-alpha. J. Clin. Endocrinol. Metab., v. 79, p. 530-536, 1994.

RAYMENT, E. A.; UPTON, Z.; SHOOTER, G. K. Increased matrix metalloproteinase-9 (MMP-9) activity observed in chronic wound fluid is related to the clinical severity of the ulcer. Br. J. Dermatol., v. 158, p. 951-961, 2008.

RAYNAL, P.; POLLARD, H. B. Annexins: the problema of assessing the biological role for a gene family of multifunctional calcium-and phospholipid-binding proteins. Biochem. Biophys. Acta, v. 1197, p. 63-93, 1994.

REES, R. S.; O'LEARY, J. P.; KING, L. E. The pathogenesis of systemic loxoscelism following brown recluse spider bites. J. Surg. Res., v. 35, p. 1-10, 1983.

REES, R. S.; NANNEY, L. B.; YATES, R. A.; KING, L. J. Interaction of brown recluse spider venom on cell membranes: the inciting mechanism? J. Invest. Dermatol., v. 83, p. 270-275, 1984.

REISS, M. J.; HAN, Y. P.; GARCIA, E.; GOLDBERG, M.; YU, H.; GARNER, W. L. Matrix metalloproteinase-9 delays wound healing in a murine wound model. Surgery, v. 147, n. 2, p. 295-302, 2010.

REKOW, M. A.; CIVELLO, D. J.; GEREN, C. R. Enzymatic and hemolytic properties of brown recluse spider (Loxosceles reclusa) toxin and extracts of venom apparatus, cephalothorax and abdomen. Toxicon, v. 21, n. 3, p. 441-444, 1983.

RIBEIRO, L. A.; EICKSTEDT, V. R. D.; RÚBIO, G. B. G.; KONOLSAISEN, J. F.; HANDAR, Z.; ENTRES, M.; CAMPOS, V. A. F. P.; JORGE, M. T. Epidemiologia do acidente por aranhas do gênero Loxosceles Heinecken e Lowe no estado do Paraná (Brasil). Mem. Instituto Butantan, v. 55, p. 19-26, 1993.

ROBERTS, R. A.; SMITH, R.; LASKIN, D.; ROBERTSON, F.; DOORN, J.; SLIKKER, W. Nitrative and oxidative stress in toxicology and disease. Toxicol. Sci., v. 112, p. 4-16, 2009a.

ROBERTS, R. A.; LASKIN, D. L.; SMITH, C. V.; ROBERTSON, F. M.; ALLEN, E. M. G.; DOORN, J. A.; SLIKKER, W. Nitrative and oxidative stress in toxicology and disease. Toxicol. Sci., v. 112, p. 4-16, 2009 b.

ROLAIN, J. M.; MAURIN, M.; MALLET, M-N.; PARZY, D.; RAOULT, D. Culture and antibiotic susceptibility of Bartonella quintana in human erythrocytes. Antimicrobial Agents and Chemotherapy, v. 47, n. 2, p. 614-619, 2003.

ROY, S.; KHANNA, S.; NALLU, K.; HUNT, T. K.; SEN, C. K. Dermal wound healing is subject to redox control. Mol. Ther., v. 13, p. 211-220, 2006.

SARAN, M.; MICHEL, C.; BORS, W. Radical functions in vivo. A critical review of current concepts and hypotheses. Z. Natuforch., v. 53c, p. 210-227, 1998. 
SATO, M.; SAWAMURA, D.; INA, S.; YAGUCHI, T.; HANADA, K.; HASHIMOTO, I. In vivo introduction of the interleukin 6 gene into human keratinocytes: induction of epidermal proliferation by the fully spliced form of interleukin 6 , but not by the alternatively spliced form. Arch. Dermatol. Res., v. 291, p. 400-404, 1999.

SAYAMA, K.; YONEHARA, S.; WATANABE, Y.; MIKI, Y. Expression of Fas antigen on keratinocytes in vivo and induction of apoptosis in cultured keratinocytes. J. Invest. Dermatol., v. 103, n. 3, p. 330-334, 1994.

SCHNEIDER-BRACHERT, W.; TCHIKOV, V.; NEUMEYER, J.; JAKOB, M.; WINOTOMORBACH, S.; HELD-FEINDT, J.; HEINRICH, M.; MERKEL, O.; EHRENSCHWENDER, M.; ADAM, D.; MENTLEIN, R.; KABELITZ, D.; SCHUTZE, S. Compartmentalization of TNF receptor 1 signaling: internalized TNF receptosomes as death signaling vesicles. Immunity, v. 21, n. 3, p. 415-428, 2004.

SCHENONE, H.; SAAVEDRA, T.; ROJAS, A.; VILLAROEL, F. Loxoscelism in Chile. Epidemiologic, clinical and experimental studies. Rev. Inst. Med. Trop. São Paulo, v. 31, p. 403-415, 1989.

SCHULTZ, D. R. and HARRINGTON, W. J. Apoptosis: programmed cell death at a molecular level. Seminars in Arthritis and Rheumatism, v. 32, p. 345-369, 2003.

SCHWARZ, A.; BHARDWAJ, R.; ARAGANE, Y.; MAHNKE, K.; RIEMANN, H.; METZE, D.; LUGER, T.A.; SCHWARZ, T. Ultraviolet-B-induced apoptosis of keratinocytes: evidence for partial involvement of tumor necrosis factor-alpha in the formation of sunburn cells. J. Invest. Dermatol., v. 104, p. 922-927, 1995.

SEGEL, I. H. Enzyme kinetics. New York: Wiley-Interscience, 1975.

SEGEL, I. H. Enzyme kinetics: Behavior and analysis of rapid equilibrium and steadystate enzyme systems. New York: Wiley-Interscience, 1993.

SELLHEYER; K.; BICKENBACH, J. R.; ROTHNAGEL, J. A.; BUNDMAN, D.; LONGLEY, M. A.; KRIEG, T.; ROCHE, N. S.; ROBERTS, A. B.; ROOP, D. R. Inhibition of skin development by overexpression of transforming growth factor 1 in the epidermis of transgenic mice. Proc. Natl. Acad. Sci. USA, v. 90, p. 5237-5241, 1993.

SEN, C. K.; ROY, S. Redox signals in wound healing. Biochim. Biophys. Acta, v. 1780, n. 11, p. 1348-1361, 2008.

SEN, S. Programmed cell death: concept, mechanism and control. Biol. Rev. Camb. Philos. Soc., v. 67, p. 287-319, 1992.

SINGER, A. J.; CLARK, R. A. Cutaneous wound healing. N. Engl. J. Med., v. 341, p. 738746, 1999.

SHIRAKATA, Y. Regulation of epidermal keratinocytes by growth factors. J. Dermatol. Sci., v. 59, n. 2, p. 73-80, 2010. 
SIES, H. Oxidative stress: from basic research to clinical application. Am. J. Med., v. 91, p. 31S-38S, 1991.

SIMON, C.; GOEPFERT, H.; BOYD, D. Inhibition of the p38 mitogen-activated protein kinase by SB 203580 blocks PMA-induced Mr 92,000 type IV collagenase secretion and in vitro invasion. Cancer Res., v. 58, p. 1135-1139, 1998.

SISTEMA DE INFORMAÇÃO DE AGRAVOS DE NOTIFICAÇÃO (SINAN). Animais peçonhentos. Disponível em: <http://dtr2004.saude.gov.br/sinanweb/novo/>. Acesso em: 21 ago. 2012.

SMITH, C. W.; MICKS, D. W. The role of polymorphonuclear leukocytes in the lesion caused by the venom of the brown spider, Loxosceles reclusa. Lab. Invest., v. 22, p. 141$144,1970$.

SO, T.; ITO, A.; SATO, T.; MORI, Y.; HIRAKAWA, S.; Tumor necrosis factor-alpha stimulates the biosynthesis of matrix metalloproteinases and plasminogen activator in cultured human chorionic cells. Biol. Reprod., v. 46, p. 772-778, 1992.

SPURLINO, J. C.; SMALLWOOD, A. M.; CARLTON, D. D.; BANKS, T. M.; VAVRA, K. J.; JOHNSON, J. S.; COOK, E. R.; FALBO, J.; WAHL, R. C.; PULVINO, T. A.; WENDOLOSKI, J. J.; SMITH, D. L. $1.56 \AA$ estructure of mature truncated human fibroblast collagenase. Proteins: Struct. Funct. Genet., v. 19, p. 98-109, 1994.

STOOF, T.; BOORSMA, D. M.; NICKOLOFF, B. J. Keratinocytes and immunologic cytokines. In: LEIGH, I. M.; LANE, E. B.; WATT, F. M. (Ed.) The keratinocyte Handbook. Cambridge, UK, 1994. p. 365-399.

STUCKEY, J. A.; DIXON, J. E. Crystal structure of a phospholipase D a family member. Nat. Struct. Biol., v. 6, p. 278-284, 1999.

STURION et al. Utilização do dimetil sulfóxido (DMSO) no pós-operatório de mastectomias em cadelas. In: CONGRESSO BRASILEIRO DE MEDICINA VETERINÁRIA, 32. 2005, Uberlândia. Anais... Uberlândia, 2005. 1 CD-ROM. p. 1.

SUCK, D.; OEFNER, C. Structure of DNase I at $2.0 \AA$ resolution suggests a mechanism for binding to and cutting DNA. Nature, v. 321, p. 620-625, 1986.

SUCK D.; LAHM, A.; OEFNER, C. Structure refined to $2 \AA$ of a nicked DNA octanucleotide complex with DNase I. Nature, v. 332, n. 6163, p. 464-468, 1988.

TAIT, J. F.; GIBSON, D. Measurement of membrane phospholipid asymmetry in normal and sickle-cell erythrocytes by means of annexin V binding. J. Lab. Clin. Med., v. 123, p. 741$748,1994$.

TAMBOURGI, D. V.; MAGNOLI, F. C.; VON EICKSTEDT, V. R. D.; BENEDETTI, Z. C.; PETRICEVICH, V. L.; DIAS DA SILVA, W. Incorporation of a 35-kilodalton purified protein from Loxosceles intermedia spider venom transforms human erythrocytes into activators of autologous complement alternative pathway. J. Immunol., v. 155, p. 4459-4466, 1995. 
TAMBOURGI, D. V.; MAGNOLI, F. C.; VAN DEN BERG, C. W.; MORGAN, B. P.; ARAUJO, P. S.; ALVES, E. W.; DIAS DA SILVA, W. Sphingomyelinases in the venom of the spider Loxosceles intermedia are responsible for both dermonecrosis and complementdependent hemolysis. Biochem. Biophys. Res. Commun., v. 251, p. 366-373, 1998.

TAMBOURGI, D. V.; PETRICEVICH, V. L.; MAGNOLI, F. C.; ASSAF, S. L. M. R.; JANCAR, S.; DIAS DA SILVA, W. Endotoxemic-like shock induced by Loxosceles spider venoms: pathological changes and putative cytokine mediators. Toxicon, v. 36, n. 2, p. 391403, 1998a.

TAMBOURGI, D. V.; MORGAN, B. P.; GONÇALVES DE ANDRADE, R. M.; MAGNOLI, F. C.; VAN DEN BERG, C. W. Loxosceles intermedia spider envenomation induces activation of an endogenous metalloproteinase, resulting in cleavage of glycophorins from the erythrocyte surface and facilitating complement-mediated lysis. Blood, v. 95, n. 2, p. 683-691, 2000.

TAMBOURGI, D. V.; SILVA, M. S.; BILLINGTON, S. J.; GONÇALVES DE ANDRADE, R. M.; MAGNOLI, F. C.; SONGER, J. G.; VAN DEN BERG, C. W. Mechanism of induction of complement susceptibility of erythrocytes by spider and bacterial sphingomyelinases. Immunol., v. 107, p. 93-101, 2002.

TAMBOURGI, D. V.; FERNANDES-PEDROSA, M.; VAN DEN BERG, C. W.; GONÇALVES-DE-ANDRADE, R. M.; FERRACINI, M.; PAIXÃO-CAVALCANTE, D.; MORGAN, B. P.; RUSHMERE, N. K. Molecular cloning, expression, function and immunoreactivities of members of a gene family of sphingomyelinases from Loxosceles venom glands. Mol. Immunol., v. 41, n. 8, p. 831-840, 2004.

TAMBOURGI, D. V.; PAIXÃO-CAVALCANTE, D.; GONÇALVES DE ANDRADE, R. M.; FERNANDES-PEDROSA, F. M.; MAGNOLI, F. C.; MORGAN, B. P.; VAN DEN BERG, C. W. Loxosceles sphingomyelinase induces complemente- dependent dermonecrosis, neutrophil infiltration, and endogenous gelatinase expression. J. Invest. Dermatol., v. 124, p. 725-731, 2005.

TAMBOURGI, D. V.; FERNANDES-PEDROSA, F. M.; GONÇALVES DE ANDRADE, R. M.; BILLINGTON, S. J.; GRIFFITHS, M.; VAN DEN BERG, C. W. Sphingomyelinases D induce direct association of $\mathrm{C} 1 \mathrm{q}$ to the erythrocyte membrane causing complemente mediated autologous haemolysis. Mol. Immunol., v. 44, p. 576-582, 2007.

TAMBOURGI, D. V.; GONÇALVES DE ANDRADE, R. M.; VAN DEN BERG, C. W. Loxoscelism: From basic research to the proposal of new therapies. Toxicon, v. 56, n. 7, p. 1113-1119, 2010.

TANG, A.; GILCHREST, B. A. Regulation of keratinocyte growth factor gene expression in human skin fibroblasts. J. Dermatol. Sci., v. 11, p. 41-50, 1996.

TANNER, M. J. A. The major integral proteins of the human red cell. Bailliére Clin. Haematol., v. 6, p. 333-356, 1993. 
TARNUZZER, R. W.; SCHULTZ, G. S. Biochemical analysis of acute and chronic wound environments. Wound Repair Regen., v. 4, p. 321-325, 1996.

TAYLOR, R. D.; JEWSBURY, P. J.; ESSEX, J. W. A review of protein-small molecule docking methods. Journal of Computer-aided Molecular Design, v. 16, n. 3, p. 151-166, 2002.

TEST, S. T.; MITSUYOSHI, J. Activation of the alternative pathway of complement by calcium-loaded-erythrocytes resulting from loss of membrane phospholipid asymmetry. $\mathbf{J}$. Lab. Clin. Med., v. 130, p. 169-182, 1997.

TESTAI, F. D.; LANDEK, M. A.; GOSWAMI, R.; AHMED, M.; DAWSON, G. Acid sphingomyelinase and inhibition by phosphate ion: role of inhibition by phosphatidylmyoinositol 3,4,5-triphosphate in oligodendrocyte cell signaling. J. Neurochem., v. 89, p. 636644, 2004.

TOKUMURA, A.; KANAYA, Y.; MIYAKE, M.; YAMANO, S.; IRAHARA, M.; FUKUZAWA, K. Increased production of bioative lysophosphatidic acid by serum lysophospholipase D in human pregnancy. Biol. Reprod., v. 67, n. 5, p. 1386-1392, 2002.

TREFZER, U.; BROCKHAUS, M.; LOETSCHER, H.; PARLOW, F.; KAAP, A.; SCHOPF, E.; KRUTMANN, J. 55-kd tumor necrosis factor receptor is expressed by human keratinocytes and plays a pivotal role in regulation of human keratinocyte ICAM-1 expression. J. Invest. Dermatol., v. 97, p. 911-916, 1991.

TRENGOVE, N. J.; LANGTON, S. R.; STACEY, M. C. Biochemical analysis of wound fluid from nonhealing and healing chronic leg ulcers. Wound Repair Regen., v. 4, p. 234-239, 1999.

TYRRELL, R. M. Ultraviolet radiation and free radical damage to skin. Biochem. Soc. Symp., v. 61, p. 547-553, 1995.

UCHI, H.; TERAO, H.; KOGA, T.; FURUE, M. Cytokines and chemokines in the epidermis. J. Dermatol. Sci., v. 24, p. S29-38, 2000. Suppl. 1.

UCHIDA, R.; TOMODA, H.; DONG, Y.; OMURA, S. Alutenusin, a specific neutral sphingomyelinase inhibitor, produced by Penicillium sp. FO-7436. J. Antibiot., v. 52, p. 572, 1999.

UCHIDA, R.; TOMODA, H.; ARAI, M.; OMURA, S. Chlorogentisylquinone, a new neutral sphingomyelinase inhibitor, produced by a marine fungus. J. Antibiot., v. 54, p. 882, 2001.

ULRICH, D.; LICHTENEGGER, F.; UNGLAUB, F.; SMEETS, R.; PALLUA, N. Effect of chronic wound exudates and MMP-2/9 inhibitor on angiogenesis in vitro. Plast. Reconstr. Surg., v. 116, p. 539-545, 2005.

UNEMORI, E. N.; HIBBS, M. S.; AMENTO, E. P. Constitutive expression of a 92-kD gelatinase (type $\mathrm{V}$ collagenase) by rheumatoid synovial fibroblasts and its induction in normal human fibroblasts by inflammatory cytokines. J. Clin. Invest., v. 88, p. 1656-1662, 1991. 
USATYUK, P. V.; VEPA, S.; WATKINS, T.; HE, D.; PARINANDI, N. L.; NATARAJAN, $\mathrm{V}$. Redox regulation of reactive oxygen species-induced p38 MAP kinase activation and barrier dysfunction in lung microvascular endothelial cells. Antioxid. Redox Signaling, v. 5, p. 723-730, 2003.

VAN DEN BERG, C. W.; ANDRADE, R. M. G.; MAGNOLI, F. C.; TAMBOURGI, D. V. Loxosceles spider venom induces metalloproteinase mediated cleavage of MCP/CD46 and induces protection against C-mediated lyses. Immunology, v. 107, p. 102-110, 2002.

VAN DEN BERG, C. W.; GONÇALVES-DE-ANDRADE， R. M.; OKAMOTO, C. K.; TAMBOURGI, D. V. C5a receptor is cleaved by metalloproteases induced by sphingomyelinase D from Loxosceles spider venom. Immunobiology, v. 217, n. 9, p. 935941, 2012.

VAN DEN BOSCH, H. Intracellular phospholipases A. Biochem. Biophys. Acta, v. 604, p. 191-246, 1980.

VAN MEETEREN, L. A.; FREDERIKS, F., GIEPMANS, B. N.; PEDROSA, M. F.; BILLINGTON, S. J.; JOST, B. H.; TAMBOURGI, D. V.; MOOLENAAR, W. H. Spider and bacterial sphingomyelinases D target cellular lysophosphatidic acid receptors by hydrolyzing lysophosphatidylcholine. J. Biol. Chem., v. 279, p. 10833-10836, 2004.

VAN MEETEREN, L. A.; STORTELERS, C.; MOOLENAAR, W. H. Upregulation of cytokine expression in fibroblasts exposed to Loxosceles sphingomyelinase D: what is the trigger? J. Invest. Dermatol., v. 127, n. 5, p. 1266-1267, 2007.

VEIGA, S. S.; SILVEIRA, R. B.; DREYFUS, J. L.; HAOACH, J.; PEREIRA, A. M.; GREMSKI, W. Identification of high molecular weight serine-proteases in Loxosceles intermedia (brown spider) venom. Toxicon, v. 35, p. 825-839, 2000.

VERDONK, M. L.; COLE, J. C.; HARTSHORN, M. J.; MURRAY, C. W.; TAYLOR, R. D. Improved protein-ligand Docking using GOLD. Proteins: Structure, Function, and Genetics, v. 52, p. 609-623, 2003.

WALLACE, H. J.; STACEY, M. C. Levels of tumor necrosis factor-alpha (TNF-alpha) and soluble TNF receptors in chronic venous leg ulcers-correlations to healing status. J. Invest. Dermatol., v. 110, p. 292-296, 1998.

WANG, B.; ZHUANG, L.; FUJISAWA, H.; SHINDER, G. A.; FELICIANI, C.; SHIVJI, G. M.; SUZUKI, H.; AMERIO, P.; TOTO, P.; SAUDER, D. N. Enhanced epidermal Langerhans cell migration in IL-10 knockout mice. J. Immunol., v. 162, p. 277-283, 1999.

WANG, H. Q.; QUAN, T.; HE, T.; FRANKE, T. F.; VOORHEES, J. J.; FISHER, G. J. Epidermal growth factor receptor-dependent nf-kappab-independent activation of the phosphatidylinositol-3-kinase/akt pathway inhibits ultraviolet radiation-induced caspases 3,8 and 9 in human keratinocytes. J. Biol. Chem., v. 278, p. 45737-45745, 2003.

WANG, Z.; GAO, Z.; SHI, Y.; SUN, Y.; LIN, Z.; JIANG, H.; HOU, T.; WANG, Q.; YUAN, X.; ZHU, X.; WU, H.; JIN, Y. Inhibition of Smad3 expression decreases collagen synthesis in keloid disease fibroblasts. J. Plast. Reconstr. Aesthet. Surg., v. 60, p. 1193-1199, 2007. 
WASCHOLOWSKI, V.; GIANNIS, A. Sphingolactones: selective and irreversible inhibitors of neutral sphingomyelinase. Angew. Chem., v. 45, p. 827, 2006.

WASSERMAN, G. S.; ANDERSON, P. C. Loxoscelism ad necrotic arachnidism. J. ToxicolClin. Toxicol., v. 21, p. 451-472, 1983-1984.

WELZENBACH, K.; HOMMEL, U.; WEITZ-SCHMIDT, G. Small molecule inhibitors induce conformational changes in the I domain and the I-like domain of lymphocyte functionassociated antigen-1. Molecular insights into integrin inhibition. J. Biol. Chem., v. 277, n. 12, p. 10590-10598, 2002.

WERNER, S.; GROSE, R. Regulation of wound healing by growth factors and cytokines. Physiol. Rev., v. 83, n. 3, p. 835-70, 2003.

WHITE, J.; CARDOSO, J. L.; FAN, H. W. Clinical toxinology of spiders bites. In: MEIER, J.; WHITE, J. (Ed.) Handbook of clinical and toxicology of animal venoms and poisons. Boca Raton Florida: CRC Press, 1995. p. 259-330.

WILSON, J. R.; HAGOOD, C.O. JR.; PRATHER, I. D. Brown recluse spider bites: a complex problem wound. A brief review and case study. Ostomy Wound Manage, v. 51, p. 59-66, 2005.

WLASCHEK, M.; SCHARFFETTER-KOCHANEK, K. Oxidative stress in chronic venous leg ulcers. Wound Repair Reg., v. 13, p. 452-461, 2005.

WRIGHT, R. P.; ELGERT, K. D.; CAMPEBELL, B. J.; BARRETT, J. T. Hyaluronidase and esterase activities of the venom of the poisonous brown recluse spider. Arch. Biochem. Biophys., v. 159, n. 1, p. 415-426, 1973.

XIAO, L.; PIMENTEL, D. R.; WANG, J.; SINGH, K.; COLUCCI, W. S.; SAWYER, D. B. Role of reactive oxygen species and $\mathrm{NAD}(\mathrm{P}) \mathrm{H}$ oxidase in alpha(1)-adrenoceptor signaling in adult rat cardiac myocytes. Am. J. Physiol. Cell Physiol., v. 282, p. C926-C934, 2002.

YANG, J.; SALAM, A. A.; ROSEN, B. P. Genetic mapping of the interface between the ArsD metallochaperone and the ArsA ATPase. Mol. Microbiol., v. 79, n. 4, p. 872-881, 2011.

YANG, L.; CHAN, T.; DEMARE, J.; IWASHINA, T.; GHAHARY, A.; SCOTT, P. G.; TREDGET, E. E. Healing of burn wounds in transgenic mice overexpressing transforming growth factor-beta 1 in the epidermis. Am. J. Pathol., v. 159, p. 2147-2157, 2001.

YEOH-ELLERTON, S.; STACEY, M. C. Iron and 8-isoprostane levels in acute and chronic wounds. J. Invest. Dermatol., v. 121, p. 918-925, 2003.

YIN, Y.; LI, Y.; KERZIC, M. C.; MARTIN, R.; MARIUZZA, R. A. Structure of a TCR with high affinity for self-antigen reveals basis for escape from negative selection. Embo J., v. 30, n. 6, p. 1137-1148, 2011. 
YOKOMATSU, T.; MURANO, T.; AKIYAMA, T.; KOIZUMI, J.; SHIBUYA, S.; TSUJI, Y.; SOEDA, S.; SHIMENO, H. Synthesis of non-competitive inhibitors of sphingomyelinases with significant activity. Bioorg. Med. Chem. Lett., v. 13, p. 229-236, 2003.

ZHAO, Y.; NATARAJAN, V. Lysophosphatidic acid signaling in airway epithelium: role in airway inflammation and remodeling. Cell Signal, v. 21, p. 367-377, 2009.

ZHUANG, L.; WANG, B.; SHINDER, G. A.; SHIVJI, G. M.; MAK, T. W.; SAUDER, D. N. TNF receptor p55 a pivotal role in murine keratinocyte apoptosis induced by ultraviolet B irradiation. J. Immunol., v. 62, p. 1440-1447, 1999.

ZIV, E.; ROTEM, C.; MIODOVNIK, M.; RAVID, A.; KOREN, R. Two modes of ERK activation by TNF in keratinocytes: different cellular outcomes and bi-directional modulation by vitamin D. J. Cell Biochem., v. 104, p. 606-619, 2008. 